\title{
Urbanismo Ecológico, do princípio à ação: o caso de ltaquera, São Paulo, SP.
}




\section{Urbanismo Ecológico, do princípio à ação: o caso de Itaquera, São Paulo, SP.}

Tese apresentada à Faculdade de Arquitetura e Urbanismo da Universidade de São Paulo, para obtenção de grau do título de Doutor em Arquitetura e Urbanismo.

Área de concentração: Paisagem e ambiente

Orientadora: Profa. Dra. Maria de Assunção Ribeiro Franco 
AUTORIZO A REPRODUÇÃO E DIVULGAÇÃO TOTAL OU PARCIAL DESTE TRABALHO, POR QUALQUER MEIO CONVENCIONAL OU ELETRÔNICO, PARA FINS DE ESTUDO E PESOUISA, DESDE QUE CITADA A FONTE.

E-MAIL DA AUTORA: patricia@patriciaakinaga.com.br | patricia.akinaga@gmail.com

Akinaga, Patrícia Harumi

A315u Urbanismo ecológico, do princípio à ação: o caso de Itaquera, São Paulo, SP / Patrícia Harumi Akinaga. -- São Paulo, 2014.

206 p. : il.

Tese (Doutorado - Área de Concentração: Paisagem e Ambiente) - FAUUSP.

Orientadora: Maria de Assunção Ribeiro Franco

1.Paisagem urbana - São Paulo (SP) 2.Desenho urbano - São Paulo (SP) 3.Estádios 4.Urbanismo ecológico - São Paulo (SP) 5.Infraestrutura verde - São Paulo (SP) 6.Bairros ecológicos - São Paulo (SP) 7.Arena Corinthians I.Título

CDU 711.4.01(816.11) 
Patrícia Harumi Akinaga

URBANISMO ECOLÓGICO, dO PRINCíPIO À AÇÃo: 0 CASO dE ITAQUERA, SÃO PAULO, SP.

Tese apresentada à Faculdade de Arquitetura e Urbanismo da Universidade de São Paulo, para obtenção de grau do título de Doutor em Arquitetura e Urbanismo.

Aprovado em:

BANCA EXAMINADORA

Prof.Dr.

Instituição

Julgamento

Assinatura:

Prof.Dr.

Instituição

Julgamento

Assinatura:

Prof.Dr.

Instituição

Julgamento

Assinatura:

Prof.Dr.

Instituição

Julgamento

Assinatura:

Prof.Dr.

Instituição

Julgamento

Assinatura: 
Aos meus pais. 


\section{AGRADECIMENTOS}

A conclusão desta tese só foi possível devido ao imenso apoio e às palavras de incentivo que recebi de amigos, familiares, equipe do escritório e colegas profissionais e professores. A todos, com quem dividi aspirações e angústias, meus agradecimentos.

À Profa. Dra. Maria de Assunção Ribeiro Franco, pela dedicada orientação, com quem compartilho a paixão pelo planejamento ambiental e pela paisagem brasileira.

Aos professores da FAUUSP das disciplinas cursadas e da banca de qualificação pelas reflexões originadas por suas contribuições durante o desenvolvimento desta tese.

Às arquitetas e amigas Ângela Nagao e Genevieve Adele Buentello, por suas sugestões, colaboração nas ilustrações e principalmente por seu apoio, assim como de toda equipe, durante a minha ausência na execução desta pesquisa.

À arquiteta paisagista e amiga Mia Lehrer, pela inspiração em seus projetos revolucionários no contexto do Urbanismo Ecológico e pela parceria de todos estes anos que permitiu o meu crescimento dentro da profissão.

À arquiteta e amiga PriscillaTiba, pelo companheirismo durante as visitas de campo nos Estados Unidos e pelos livros compartilhados.

Ao amigo Luiz Claudio Correia dos Anjos por me proporcionar a visita à África do Sul pós Copa do Mundo onde pudemos vivenciar experiências memoráveis.

Aos arquitetos da Secretaria Municipal de Desenvolvimento Urbano da Prefeitura de São Paulo, em especial Liane Schevz, pelas informações e mapeamentos fornecidos como suporte a esta pesquisa.

À Nate Cormier e Jeffrey Hou por dividirem seu profundo conhecimento, respectivamente, sobre o sistema de drenagem natural e jardins comunitários de Seattle.

Aos meus pais, Roberto e Kiyoko, minhas irmãs, Marisa e Marcia e meu cunhado arquiteto Fernando, pelo apoio incondicional ao longo de todo meu percurso acadêmico e profissional, sem o qual não poderia ter concluído este trabalho.

Ao meu sobrinho Arthur, pela motivação em colaborar através desta pesquisa para a melhoria da qualidade ambiental e de vida nas cidades, em benefício das gerações futuras. 
¿.. nós precisamos ver a fragilidade do planeta e seus recursos como uma oportunidade para inovações exploratórias de projeto e não como uma forma de legitimação técnica para a promoção de soluções convencionais. Por extensão, os problemas das nossas cidades e regiões, então, tornam-se oportunidades para definir uma nova abordagem. Imaginar um urbanismo que é diferente do status quo requer uma nova sensibilidade - uma que tenha a capacidade de incorporar e acomodar as condições conflituosas inerentes entre ecologia e urbanismo. Este é o território do urbanismo ecológico"

(MOSTAFAVI, M., 2010/2013, p.17, tradução nossa). 


\section{RESUMO}

AKINAGA, Patrícia Harumi. Urbanismo Ecológico, do princípio à ação: o caso de Itaquera, São Paulo, SP. 2014. 206 p. Tese (Doutorado) - Faculdade de Arquitetura e Urbanismo, Universidade de São Paulo, São Paulo, 2014.

Orientadora: Profa. Dra. Maria de Assunção Ribeiro Franco

O Urbanismo Ecológico surge como uma forma de reconciliar a paisagem com a ocupação urbana, pautado pelas potencialidades e limitações dos recursos naturais. As áreas verdes não exercem a função somente do embelezamento e da melhoria da qualidade visual e ambiental, elas se transformam em verdadeiros artefatos de engenharia e elementos de uma infraestrutura verde de alto desempenho. A arborização viária ganha força e escala ao conectar fragmentos de florestas urbanas e áreas verdes dispersas no tecido urbano. Os resultados da pesquisa mudam o olhar sobre a várzea dos rios. Renegadas na cidade contemporânea, no Urbanismo Ecológico, as planícies fluviais se tornam elementos estruturais e conectores da malha urbana e de grande valor. A tese parte da hipótese de que é possível implantar o Urbanismo Ecológico em São Paulo através da execução de um processo amplo e ferramentas que vão de políticas públicas, ações da iniciativa privada e envolvimento comunitário, tendo como consequência a melhoria da qualidade ambiental e de vida urbana. A pesquisa foca em Itaquera, bairro impactado pela implantação de grandes equipamentos urbanos pertencentes ao polo institucional e que abriga o novo estádio de futebol do clube Corinthians, para realização de jogos da Copa do Mundo de 2014. Através de levantamentos de campo, mapeamentos e análise de estudos de caso nos Estados Unidos e na África do Sul, identifica-se a clara oportunidade de transformação no entorno da arena a partir da aplicação de princípios ecológicos. Por fim, a pesquisa apresenta uma proposta de Urbanismo Ecológico para o entorno da Arena Corinthians, a partir de suas potencialidades locais, suas áreas verdes, sua hidrografia e a sua nova dinâmica decorrente de novos investimentos públicos e privados.

Palavras-chave: Urbanismo ecológico, Paisagem urbana, Desenho urbano, Infraestrutura verde, Bairros ecológicos, Estádios, Arena Corinthians. 


\section{ABSTRACT}

AKINAGA , Patricia Harumi . Ecological Urbanism, from the principle to the action: the case of Itaquera , São Paulo , SP . 2014. 206 p . Thesis (Ph.D.) - College of Architecture and Urbanism, University of São Paulo, São Paulo , 2014.

Thesis Advisor: Prof. Dr. Maria de Assunção Ribeiro Franco

Ecological Urbanism has emerged as a way to reconcile the landscape with urban occupation, ruled by the potentialities and limitations of natural resources. Green areas do not function only beautifying and improving the visual and environmental quality, they become true engineering artifacts and elements of a high performance green infrastructure. The street tree system gains strength and scale while connecting fragments of urban forests and green areas scattered in the urban fabric. The research results change the look on the river floodplains. Segregated in the contemporary city, under Ecological Urbanism principles, floodplains become structural elements and links of the urban fabric adding great value. The thesis presents the hypothesis that it is possible to implement the Ecological Urbanism in São Paulo through the implementation of a comprehensive process and tools ranging from public policies, private sector actions and community engagement resulting on the improvement of environmental quality and urban life. The research focuses on Itaquera neighborhood impacted by the implementation of large urban facilities part of an institutional hub and home to the new soccer stadium of Corinthians club that will host World Cup 2014 games. Through field surveys, mapping and analysis of case studies in the United States and in South Africa is possible to identify a clear opportunity for transformation in the vicinity of the arena based on ecological principles. At last, the research presents an Ecological Urbanism proposal for the surroundings of the Arena Corinthians taking advantage of its local potentiality, green areas, hydrograph and new dynamic as a result of new public and private investments.

Keywords: Ecological urbanism, Urban landscape, Urban design, Green infrastructure, Ecological neighborhoods, Stadiums, Arena Corinthians. 


\section{LISTA DE FIGURAS E TABELAS}

FIGURAS

\begin{tabular}{|c|c|c|}
\hline Figura 01 & Transepto de diversas paisagens, base de estudo para o Crescimento Inteligente. & p. 12 \\
\hline Figura 02 & Sistema de transporte sobre trilhos em Portland, Estados Unidos. & p. 16 \\
\hline Figura 03 & Alagados construídos para tratamento de efluentes domésticos. & p. 18 \\
\hline Figura 04 & Diagrama de Corredores Sustentáveis. & p.28 \\
\hline Figura 05 & Diagrama de Bairro Sustentável. & p.31 \\
\hline Figura 06 & Implantação geral do bairro High Point em Seattle. & p.34 \\
\hline Figura 07 & Relatório de Consumo de água do jardim comunitário de Cascade em Seattle. & p.68 \\
\hline Figura 08 & Cascade P-Patch Garden, portal de entrada. & p.69 \\
\hline Figura 09 & Mapa do jardim Danny Woo International & p.73 \\
\hline Figura 10 & Pórtico de entrada, desenho claramente oriental. & p.75 \\
\hline Figura 11 & A comunicação visual é resultado do processo participativo. & p.75 \\
\hline Figura 12 & Canteiros em diferentes estágios de desenvolvimento. & p.76 \\
\hline Figura 13 & Arte pública como resultado do processo coletivo de construção do jardim comunitário. & p.77 \\
\hline Figura 14 & Placas de sinalização e comunicação visual nos canteiros educativos. & p.78 \\
\hline Figura 15 & Elementos lúdicos no cercamento do parque infantil. & p.79 \\
\hline Figura 16 & $\begin{array}{l}\text { As práticas sustentáveis estão presentes em placas de sinalização como "usar a água } \\
\text { com consciência". }\end{array}$ & p.80 \\
\hline Figura 17 & Entrada das "escadas cisternas" da Vine Street. & p.81 \\
\hline Figura 18 & $\begin{array}{l}\text { Sinalização dos caminhos entre canteiros, como parte do sistema de localização e } \\
\text { referência wayfinding }\end{array}$ & p.82 \\
\hline Figura 19 & Área para eventos no centro do jardim. & p.84 \\
\hline Figura 20 & Canteiros de produção com placas com nomes das espécies. & p.85 \\
\hline Figura 21 & Área de compostagem junto a um dos pontos de irrigação. & p.86 \\
\hline Figura 22 & Gradil baixo e transparente ao longo de todo perímetro. & p.87 \\
\hline Figura 23 & Placa padrão da Prefeitura de Seattle. & p.88 \\
\hline Figura 24 & Sinalização para controle de comportamento no parque, placas regulamentadoras. & p.88 \\
\hline Figura 25 & As ferramentas de jardinagem estão disponíveis e devidamente identificadas. & p.89 \\
\hline Figura 26 & Local para compostagem com placas de educação ambiental. & p.90 \\
\hline Figura 27 & Relatórios e placas regulamentadoras são colocadas próximas a uma das entradas. & p.90 \\
\hline
\end{tabular}




\begin{tabular}{|c|c|c|}
\hline Figura 28 & Sacos de juta de embalagem de café brasileiro cobrem os canteiros em fase de germinação. & p.91 \\
\hline Figura 29 & $\begin{array}{l}\text { Os canteiros de produção de legumes e verduras são para consumo dos participantes ou } \\
\text { para doação. }\end{array}$ & p.92 \\
\hline Figura 30 & A arte pública é uma atração à parte do jardim que atrai turistas. & p.92 \\
\hline Figura 31 & Placas com mensagem dos participantes, parte do programa educativo. & p.93 \\
\hline Figura 32 & Placa com o telefone do programa para que as pessoas não peguem frutos, flores e verduras. & p.93 \\
\hline Figura 33 & Exemplo de SEA Street em Seattle (2nd Ave.). & p.99 \\
\hline Figura 34 & Mapa que ilustra as bacias hidrograficas de Seattle. & p.101 \\
\hline Figura 35 & Biovaleta na 2nd Ave. & p. 105 \\
\hline Figura 36 & Second Ave depois da implantação do projeto. & p.105 \\
\hline Figura 37 & $\begin{array}{l}\text { Corte de rua típica do bairro High Point desenvolvido pelo escritório SvR Design } \\
\text { Company de Seattle. }\end{array}$ & p.107 \\
\hline Figura 38 & Jardim de chuva no bairro de High Point. & p.108 \\
\hline Figura 39 & Jardim de chuva no bairro de High Point. & p.109 \\
\hline Figura 40 & Imagem de implantação do jardim de chuva das ruas 67th Street e 28th Avenue (NW). & p.112 \\
\hline Figura 41 & Plano geral do Piggyback Yard, área verde central e alagados para controle de enchentes. & p.117 \\
\hline Figura 42 & $\begin{array}{l}\text { Imagem área do Piggyback Yard ilustrando sua proximidade com a rede de infraestrutura } \\
\text { de transportes e a área central da cidade de Los Angeles. }\end{array}$ & p.118 \\
\hline Figura 43 & Vista dos alagados. & p.119 \\
\hline Figura 44 & Vista da belvedere. & p.119 \\
\hline Figura 45 & Ilustração em camadas do projeto Piggyback Yard baseado na infraestrutura verde. & p. 120 \\
\hline Figura 46 & Vista da orla de São Francisco. & p.124 \\
\hline Figura 47 & Vista do parque Brannan Street Wharf. & p.125 \\
\hline Figura 48 & AT\&T Park - São Francisco, California, Eua & p. 126 \\
\hline Figura 49 & Vista do estádio inserido na orla de China Basin. & p.127 \\
\hline Figura 50 & Vista geral do estádio e de seu entorno. & p. 127 \\
\hline Figura 51 & Perímetro da área de estudo definido a partir do centro da arena STAPLES. & p. 129 \\
\hline Figura 52 & Mapa elaborado a partir do censo de 2000. Concentração de população por idade. & p.131 \\
\hline Figura 53 & Mapa elaborado a partir do censo de 2000. Mapa de densidades. & p.132 \\
\hline Figura 54 & Mapa elaborado a partir do censo de 2000 . Concentração de população por renda. & p.133 \\
\hline Figura 55 & Mapa elaborado a partir do censo de 2000. Mapa de prioridades. & p.134 \\
\hline Figura 56 & Arena STAPLES Center implantada na área central de Los Angeles. & p.135 \\
\hline
\end{tabular}




\begin{tabular}{|c|c|c|}
\hline Figura 57 & Mapa com ilustração das áreas verdes desejadas pela comunidade sobre foto aérea do Google. & p. 136 \\
\hline Figura 58 & Imagem ilustrativa do pequeno parque. & p. 137 \\
\hline Figura 59 & Viela de serviço antes da intervenção. & p.138 \\
\hline Figura 60 & Vila após a intervenção. & p. 138 \\
\hline Figura 61 & Área de estacionamento subutilizada antes da intervenção. & p.139 \\
\hline Figura 62 & Parque médio implantado em área de estacionamento subutilizada. & p. 139 \\
\hline Figura 63 & Área potencial para implantação de um parque grande antes da intervenção. & p. 140 \\
\hline Figura 64 & Parque grande implantado em área subutilizada dentro da área de estudo. & p. 140 \\
\hline Figura 65 & Arena Staples - Los Angeles, California, Eua & p. 142 \\
\hline Figura 66 & Arena Soccer City - Johannesburg, Africa do Sul & p. 145 \\
\hline Figura 67 & Estádio Soccer City, fachada principal. & p.146 \\
\hline Figura 68 & Via de acesso principal ao estádio com vários terrenos vagos em ambos os lados. & p.149 \\
\hline Figura 69 & Terreno vago no entorno do Soccer City. & p. 149 \\
\hline Figura 70 & Acesso principal ao estádio Soccer City, entorno sem desenvolvimento. & p. 150 \\
\hline Figura 71 & Totem de sinalização da Copa ainda presente no local em terreno vago. & p. 150 \\
\hline Figura 72 & Vista do rio Klipspruit presente na área da vizinhança do estádio Soccer City. & p.151 \\
\hline Figura 73 & $\begin{array}{l}\text { Potencialidade para a configuração de uma infraestrutura verde para o entorno do Soccer } \\
\text { City ao longo do Rio Klipspruit. }\end{array}$ & p.152 \\
\hline Figura 74 & Arena Corinthians e polo institucional. & p.156 \\
\hline Figura 75 & Córrego Rio Verde no entorno da Arena Corinthians. & p.156 \\
\hline Figura 76 & Arena Corinthians em obra. & p.158 \\
\hline Figura 77 & Conjuntos habitacionais no entorno da Arena Corinthians. & p.159 \\
\hline Figura 78 & Tipologia representativa das ruas do entorno da Arena Corinthians em Itaquera. & p.159 \\
\hline Figura 79 & $\begin{array}{l}\text { Imagem extraída do livro "A Leste do Centro" que ilustra o perímetro do Vetor Leste do } \\
\text { Centro. Itaquera se desenvolve ao longo da Linha } 3 .\end{array}$ & p. 160 \\
\hline Figura 80 & Parque do Carmo. & p. 163 \\
\hline Figura 81 & Contexto geográfico da área de estudo localizada entre a Serra da Cantareira e a Serra do Mar. & p.165 \\
\hline Figura 82 & Localização da abrangência da área de estudo na zona leste do município de São Paulo. & p.166 \\
\hline Figura 83 & $\begin{array}{l}\text { Localização da Arena Corinthians e sua área de influência entre a Serra da Cantareira, a APA } \\
\text { do Carmo, e a Serra do Mar. }\end{array}$ & p.167 \\
\hline Figura 84 & Estrutura geológica da área. & p.168 \\
\hline Figura 85 & Principais cursos d'água da área de influência da Arena Corinthians. & p.169 \\
\hline
\end{tabular}




\begin{tabular}{|c|c|c|}
\hline Figura 86 & Uso de solo da área de influência da Arena Corinthians. & p. 171 \\
\hline Figura 87 & Área de influência da Arena Corinthians. & p. 173 \\
\hline Figura 88 & $\begin{array}{l}\text { Potencialidades do sistema de trânsito e tranporte como eixos de conexão dos espaços } \\
\text { verdes existentes. }\end{array}$ & p.174 \\
\hline Figura 89 & Espaços subutilizados presentes na área de estudo. & p.175 \\
\hline Figura 90 & Áreas verdes existentes fragmentadas. & p.176 \\
\hline Figura 91 & $\begin{array}{l}\text { Conexão das áreas verdes através da criação de caminhos verdes ao longo dos cursos } \\
\text { d'água e do sistema viário. }\end{array}$ & p.177 \\
\hline Figura 92 & Caminho verde ao longo da Rua Itaquera. & p. 179 \\
\hline Figura 93 & Área verde proposta ao longo da Rua Dr. Luis Aires. & p. 180 \\
\hline Figura 94 & Transepto da situação existente: áreas verdes fragmentadas sem conexão. & p.181 \\
\hline Figura 95 & Infraestrutura verde proposta. & p.182 \\
\hline Figura 96 & $\begin{array}{l}\text { Análise das condições existentes em camadas e criação da infraestrutura verde no entor- } \\
\text { no da Arena Corinthians. }\end{array}$ & p.184 \\
\hline Figura 97 & Análise das condições existentes em escala local $20 \mathrm{~min}$. de caminhada do centro da arena. & p.185 \\
\hline Figura 98 & Hortas comunitárias como parte da infraestrutura verde e do urbanismo ecológico. & p.186 \\
\hline Figura 99 & Jardins de chuva - sistema de drenagem natural com a substituição de infraestrutura tradicional. & p.187 \\
\hline Figura 100 & Sistema de drenagem natural com a substituição gradual da infraestrutura tradicional. & p.188 \\
\hline Figura 101 & Criação de novas centralidades (uso do solo, diversificação, e densidades média e alta). & p.189 \\
\hline Figura 102 & Paisagem existente no entorno da arena. & p. 190 \\
\hline Figura 103 & Paisagem proposta no entorno da arena. & p.191 \\
\hline Figura 104 & Paisagem existente no entorno da Arena Corinthians. & p.193 \\
\hline Figura 105 & $\begin{array}{l}\text { Paisagem urbana no entorno da Arena Corinthians após aplicação dos princípios do } \\
\text { Urbanismo Ecológico. }\end{array}$ & p.193 \\
\hline Figura 106 & Área antes da construção da Arena Corinthians e arredores: áreas verdes fragmentadas. & p.194 \\
\hline Figura 107 & $\begin{array}{l}\text { Áreas verdes públicas no entorno da Arena Corinthians com a implementação do Urba- } \\
\text { nismo Ecológico: jardins de chuva, áreas verdes qualificadas e conectadas, uso do solo } \\
\text { diversificado, novas centralidades. }\end{array}$ & p.195 \\
\hline Figura 108 & Arenas de futebol nas cidades sede da Copa do Mundo 2014 no Brasil. & p. 198 \\
\hline
\end{tabular}

\section{TABELAS}

\begin{tabular}{|l|l|r|}
\hline Tabela 1.1 & Parâmetros de conservação para o planejamento do Environmental Law Institute & p.29 \\
\hline Tabela 3.1 & O Surgimento da infraestrutura verde. & p.49 \\
\hline Tabela 3.2 & As ferramentas para implantação da Infraestrutura Verde & p.59 \\
\hline Tabela 8.1 & Evolução populacional dos distritos da Subprefeitura de Itaquera. & p.161 \\
\hline
\end{tabular}




\section{SUMÁRIO}

INTRODUÇÃO

\section{CAPÍTULO 1 - OS CONCEITOS DE CRESCIMENTO INTELIGENTE, URBANISMO}

PAISAGÍSTICO E URBANISMO ECOLÓGICO ................................................................. 10

1.1 Smart Growth, Crescimento Inteligente ......................................................... 11

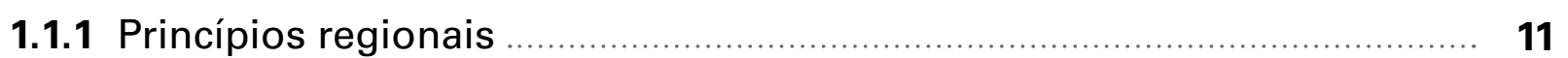

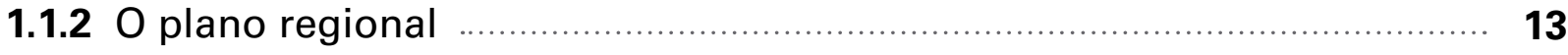

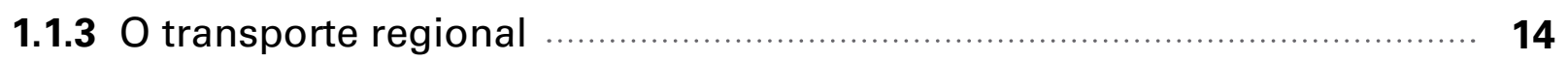

1.1.4 O bairro e sua paisagem natural …............................................... 16

1.1.5 O bairro e seus elementos …..................................................... 19

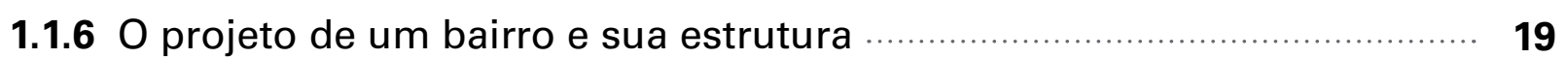

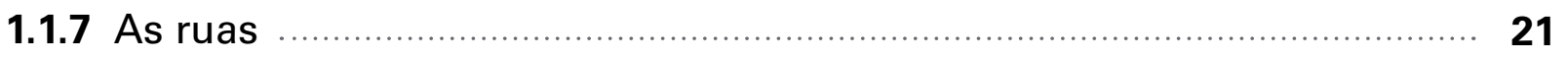

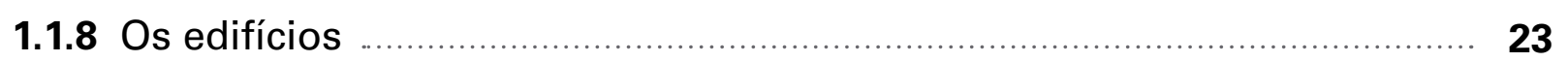

1.2 Landscape Urbanism, Urbanismo Paisagístico ……......................................... 24

1.3 Ecological Urbanism, Urbanismo Ecológico …............................................... 26

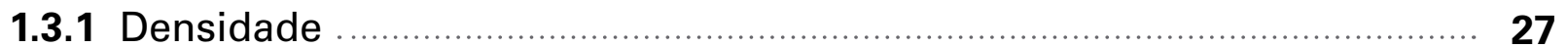

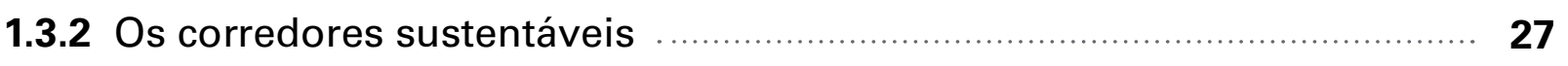

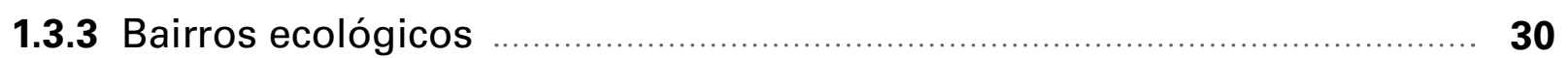

1.3.4 Espaços livres, elementos da infraestrutura verde ............................... $\mathbf{3 1}$

1.3.5 Os edifícios verdes e a infraestrutura de alto desempenho ..................... 32

1.3.6 Estudo de caso High Point Seattle …….................................................. 33

1.4 Planejamento ambiental e o caso da cidade de São Paulo .................................. 35

CAPÍTULO 2 - O CONCEITO DE PAISAGEM ........................................................................ 38

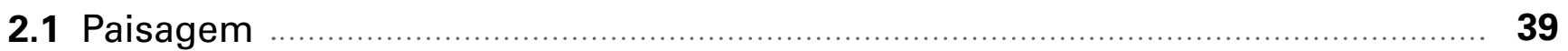

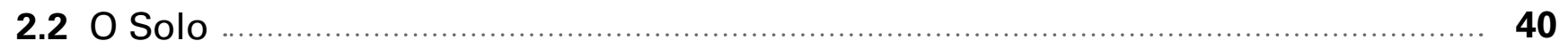

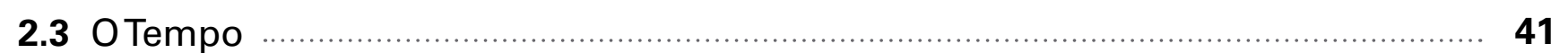


CAPÍTULO 3 - O CONCEITO DA INFRAESTRUTURA VERDE E O NOVO PARADIGMA PARA O DESENHO DOS BAIRROS

3.1 A rede da Infraestrutura verde

3.2 A escala da Infraestrutura verde

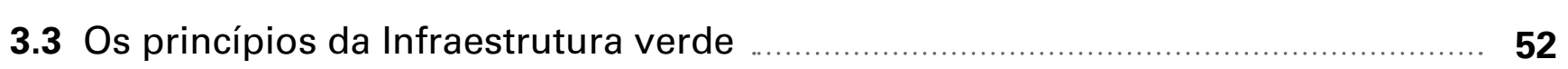

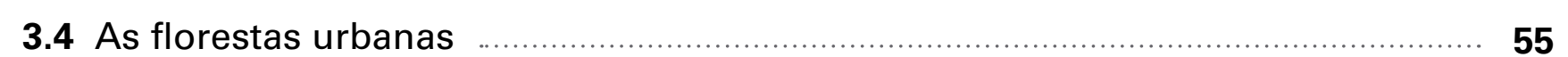

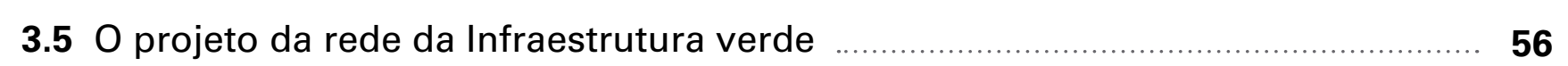

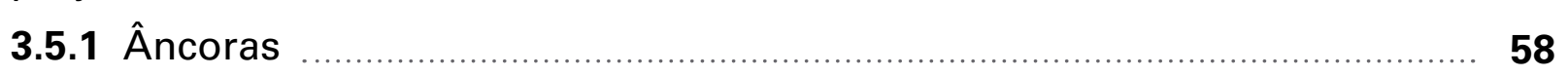

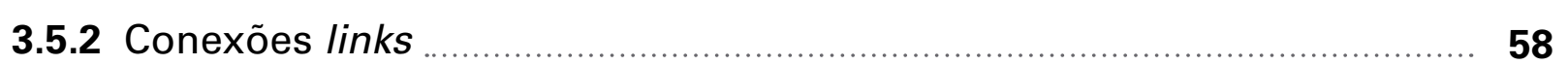

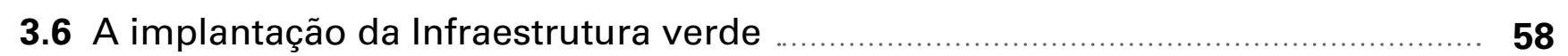

CAPÍTULO 4 - O CONCEITO DA AGRICULTURA URBANA COMUNITÁRIA COMO

ESTRATÉGIA DE INFRAESTRUTURA VERDE NOS BAIRROS .............................................6. 62

4.1 O urbanismo ecológico e os jardins comunitários …....................................66

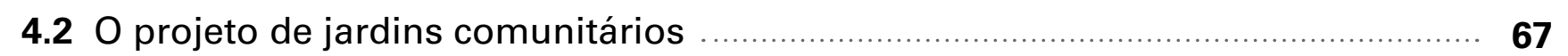

4.3 Estudos de caso na cidade de Seattle, Estados Unidos .................................. 70

4.3.1 Histórico ........................................................................................... 70

4.3.2 O Programa P-Patch e sua contribuição para a infraestrutura verde de Seattle. 72

4.3.3 Danny Woo International Community ............................................... 73

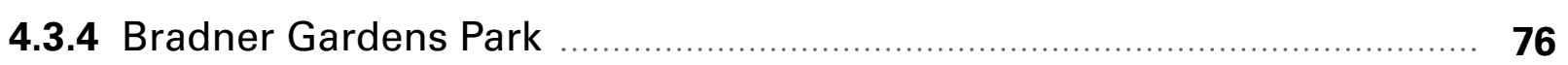

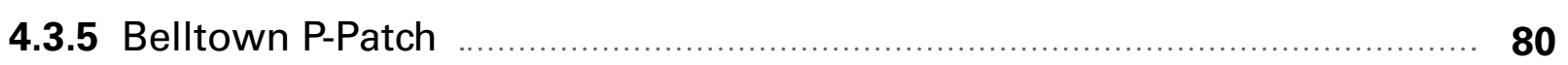

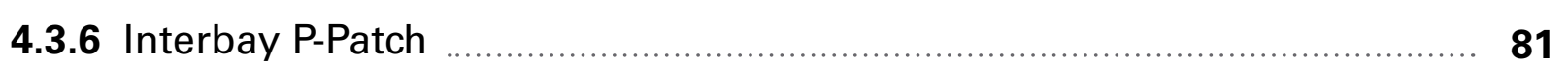

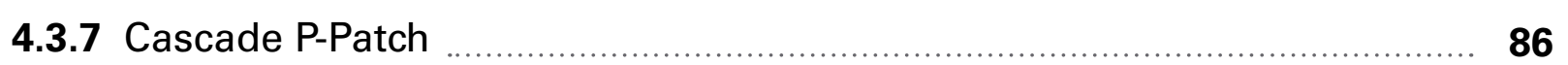

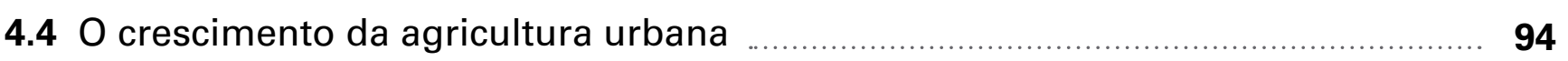

CAPÍTULO 5 - SEATTLE E LOS ANGELES: PROJETOS DE INFRAESTRUTURA VERDE NA ESCALA DO BAIRRO

5.1 Projeto das bacias hidrográficas da cidade de Seattle

5.1.1 Os benefícios do sistema de drenagem natural (NDS) .......................... 98

5.1.2 O sistema de drenagem 101 de Seattle ................................................... 102

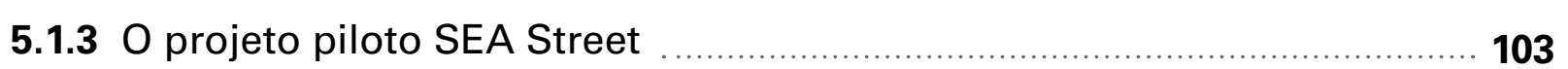

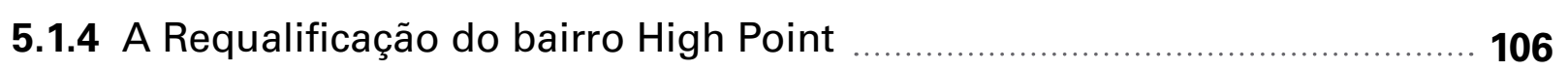

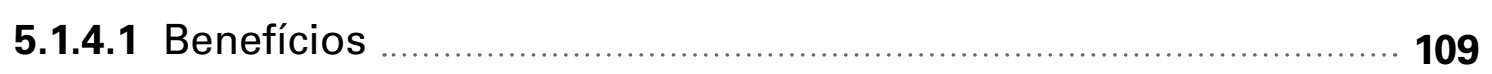

5.1.4.2 Cronograma de implantação …….......................................... 110 
5.2 Rua Cascade e a rua Noroeste 110

5.3 A malha verde Broadview

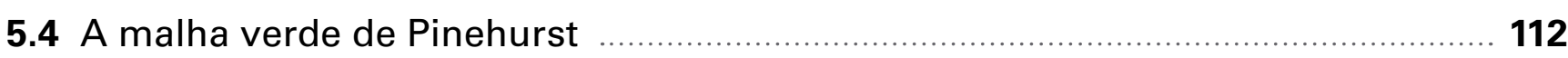

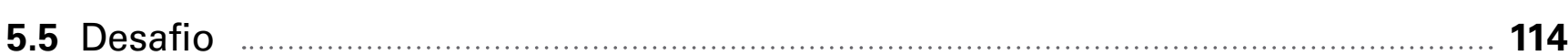

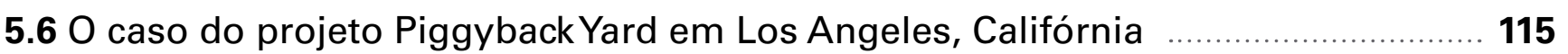

PARTE III - ESTÁDIOS COMO ELEMENTOS CATALISADORES DETRANSFORMAÇÃO URBANA, OPORTUNIDADES PARA O SURGIMENTO DO URBANISMO ECOLÓGICO

\section{CAPÍTULO 6 - O CASO DO AT\&T PARK EM SÃO FRANCISCO E DA ARENA STAPLES} CENTER EM LOS ANGELES

6.1 AT\&T Park, estádio de beisebol na área do Porto de São Francisco

6.2 Arena STAPLES Center e o plano de espaços livres para o centro de Los Angeles

6.2.1 Protótipos propostos para futuros espaços públicos na área de intervenção.

6.2.1.1 Protótipo 1 - pequeno parque

6.2.1.2 Protótipo 2 - pequeno parque em viela

CAPÍTULO 7 - O IMPACTO AMBIENTAL DO ESTÁDIO SOCCER CITY DA AFRICA DO SUL...

7.1 O estádio Soccer City e os projetos públicos como legado

7.2 A Região F de Johannesburgo

8.2 Arena como um ícone e elemento de identidade

8.3 A expansão da Zona Leste de São Paulo

8.4 O bairro de Itaquera, referências históricas 


\section{INTRODUÇÃO}

Esta tese apresenta o Urbanismo Ecológico como uma forma de reconciliar a paisagem com a ocupação urbana através da mudança de paradigma onde o desenho urbano é pautado pelas potencialidades e limitações dos recursos naturais. Este conceito norteou o surgimento de movimentos em contraposição ao Novo Urbanismo que tem no edifício, o elemento estruturador das cidades. No final do século XX os precursores do Crescimento Inteligente, do Urbanismo Paisagístico e do Urbanismo Ecológico, cujas semelhanças e diferenças serão apresentadas na parte I deste trabalho, iniciaram debates e reflexões sobre projetos urbanos de baixo impacto ambiental.

Surge uma nova tipologia de rua, que aproveita os espaços verdes não só para o embelezamento e a melhoria da qualidade visual. Estes se transformam em verdadeiros artefatos de engenharia e elementos de uma infraestrutura verde de alto desempenho. A arborização viária ganha força e escala ao conectar fragmentos de florestas urbanas e áreas verdes dispersas no tecido urbano.

Outro exemplo é o papel de jardins comunitários dentro dos bairros que promovem educação ambiental e produção local de alimentos como parte da estratégia para se atingir o equilíbrio entre a área rural e a área urbana. A expansão urbana cresce em detrimento de áreas de fragilidade ambiental e áreas de produção de alimentos. Tal produção não suprirá a necessidade local de consumo, mas, sem dúvida, traz à tona o debate e inovações, além de fomentar a cidadania, o processo participativo e de manter áreas verdes em terrenos antes subutilizados dentro dos bairros.

O olhar sobre a várzea dos rios muda. Renegadas na cidade contemporânea, no Urbanismo Ecológico, as planícies fluviais se tornam elementos estruturais e conectores da malha urbana de grande valor.

Implementar o Urbanismo Ecológico pressupõe a execução de um processo amplo com ferramentas que vão de políticas públicas, ações da iniciativa privada e envolvimento comunitário. A pesquisa analisa o Urbanismo tendo como elemento estruturador de sua ocupação e expansão a sua paisagem e não a sua arquitetura. 
A intervenção em áreas já consolidadas apresenta-se como desafio aos arquitetos e urbanistas. É sempre onerosa em função de demolições, eventuais desapropriações e a necessidade do pacto entre diversos segmentos da sociedade para que ela se concretize. Por esta razão, para comprovação da hipótese de que a implementação do Urbanismo Ecológico melhora a qualidade da vida urbana e contribui para um maior equilíbrio ambiental, a pesquisa foca em Itaquera, bairro impactado pela implantação de grandes equipamentos urbanos pertencentes ao polo institucional e que abriga o novo estádio de futebol do clube esportivo Corinthians para realização de jogos da Copa do Mundo de 2014. Existe clara oportunidade de transformação a partir do novo modelo de ocupação, induzido por uma legislação urbanística passível de ser formatada a partir de princípios ecológicos.

A pesquisa ainda reflete sobre o papel crescente do arquiteto paisagista e urbanista no desenho da paisagem urbana contemporânea, como coordenador do processo de implantação deste modelo de urbanismo que tem na sua essência inovações na área de infraestrutura.

A atual discussão sobre a influência das alterações nas características físicas do território através do urbanismo e seus impactos sobre a qualidade de vida não é recente. Em 1847, George Perkins Marsh, autor de Man and Nature, Homem e Natureza, discursou na Associação de Agricultura do Condado de Rutland em Vermont sobre o impacto destrutivo das atividades humanas sobre a terra, especialmente através do desmatamento, e pediu aos conservacionistas atenção ao manejo florestal. Na mesma época, Henry DavidThoreau escreveu sobre a importância de se preservar a natureza e aplicou suas ideias ao desenho urbano (BENEDICT, McMAHON, 2006, p. 25).

O arquiteto paisagista Frederick Law Olmsted compartilha da mesma opinião deThoreau de que o ambiente urbano, “biologicamente artificial” degrada a saúde mental e física humana e incorporou parques e corredores verdes nos seus planos urbanos nos Estados Unidos. Em 1868, no seu plano para Riverside, Illinois, Olmsted introduziu um amplo espaço verde para recreação e se certificou de que todos os residentes tivessem acesso a paisagens interessantes e cênicas. A fim de atingir este objetivo, ele preservou a várzea do rio e duas áreas verdes nas terras mais altas e criou uma via parque bem arborizada para conectar Riverside a Chicago. O traçado viário projetado segue a topografia existente. 
No século XIX Olmsted foi um visionário e a partir da riqueza dos elementos naturais presentes no local, projetou espaços públicos importantes na paisagem urbana das cidades em que atuou. Seus projetos são valorizados pela qualidade de vida que oferece aos seus usuários como, por exemplo, o Emerald Necklace de Boston e o Central Park de Nova York. Olmsted acreditava que as áreas verdes traziam paz à mente e senso de liberdade, ao mesmo tempo em que preservavam e melhoravam a qualidade das águas. No entanto, um parque isolado não poderia proporcionar todos estes benefícios.

O Emerald Necklace, Colar de Esmeraldas, projetado em 1887 é um sistema de parques e corredores verdes conectados. A sua rede inclui o Boston Public Garden, o Boston Common, a Avenida Commonwealth, the Back Bay Fens, os rios, o Parque Olmsted, o Parque Jamaica, o Horto Arnold e o Parque Franklin, conectados por uma série de vias parque. Atualmente, o Emerald Necklace provê um respiro para o stress da cidade e serve de habitat para uma série de espécies raramente vistas em meio urbano. Além disso, o Emerald Necklace funciona como um reservatório de água, proteção contra enchentes e outros benefícios ambientais, um exemplo disso é a recuperação da área de mangue Back Bay Fens para filtração de águas pluviais (BENEDICT, McMAHON, 2006, p. 26).

A ideia de se preservar as áreas verdes em meio urbano também foi incorporada por profissionais europeus. O movimento da Garden City, Cidade Jardim na Inglaterra, liderado pelo planejador urbano Ebenezer Howard, focava na importância de se equilibrar desenvolvimento urbano e a existência da natureza. Em seu plano para Victoria, Inglaterra ele propôs um cinturão verde para fins rurais ao longo do perímetro da cidade, além de bulevares de 40 metros de largura densamente plantados (BENEDICT, McMAHON, 2006, p. 27).

No início do século XX, o fundador do Sierra Club John Muir, Gifford Pinchot e o PresidenteTheodore Roosevelt levaram a ideia de conservação para a pauta nacional e deram origem ao sistema de parques nacionais a fim de preservar a vida selvagem e espaços para o uso de gerações futuras. Durante seu mandato, Roosevelt protegeu cerca de 93 milhões de hectares em todo o país. 
1 MC'HARG, lan L. Proyetar con la Naturaleza. Barcelona, Gustavo Pili, 2000 (1967).

2 HOUGH, Michael. Ciudad y Naturaleza. Planificación Urbana y Processos Ecológicos. Barcelona, Gustavo Pili, 1998(1995)

\footnotetext{
${ }^{3}$ FARR, Douglas. Sustainable urbanism: urban design with nature. New Jersey, John Wiley \& Sons, 2008.

4 Douglas Farr é arquiteto e urbanista, fundador da Farr Associates de Chicago, EUA. Sua empresa foi a primeira do mundo a receber certificação LEED Platinum em dois de seus projetos, o Chicago Center for Green Technology e o Center for Neighborhood Technology.

ALEXANDER, Christopher, ISHIKAWA, Sara, SILVERSTEIN, Murray. A pattern language: towns, buildings, construction. Oxford University Press, London, 1977.
}

Na década de 60, em seu livro Proyetar con la Naturaleza ${ }^{1}$, o escocês lan McHarg discorreu sobre a importância das condicionantes ambientais no planejamento dos assentamentos urbanos e da preservação da natureza. McHarg foi um dos precursores do GIS (Geographic Information System) e do modelo de planejamento através da seção transversal do território (natural transect). Ele introduziu a ideia do "determinismo fisiográfico", de que os processos naturais deveriam servir de base para se determinar as áreas a serem desenvolvidas e as áreas a serem preservadas. Segundo McHarg, a forma não deve seguir somente a função e sim respeitar o ambiente natural onde ela se insere. Ele criou um método através da sobreposição de mapeamentos para facilitar a leitura dos dados.

Já na década de 90, Michael Hough, arquiteto paisagista, sócio do escritório Hough Stansbury Naylor Dance e professor da Faculdade de Estudos Ambientais daYork University do Canadá escreve Ciudad y Naturaleza². O autor aborda a separação entre o campo e a cidade, o desperdício de recursos e como os valores econômicos e tecnológicos retiraram a consciência da importância da natureza na constituição da cidade moderna.

Emuma leitura recente sobre a questão dos bairros ecológicos e do urbanismo sustentável, no livro Sustainable Urbanism, Urban Design with Nature ${ }^{3}$, de Douglas Farr ${ }^{4}$, o autor reforça a ideia de Christopher Alexander de "A pattern language" 5 de que os assentamentos humanos são a variável da equação ambiental e demonstra através de estudos de caso em diversos países a eficiência da certificação LEED, criada pelo Green Building Council dos Estados Unidos (USGBC) na construção de comunidades verdes.

Os problemas decorrentes do que muitos denominam de urbanização predatória são as alterações no microclima (radiação solar, ventos, umidade e temperatura), na dinâmica da fauna e da flora e no cotidiano dos usuários das cidades. A situação é agravada pela relação direta destes fatores com a forma contemporânea de produção urbana. Por exemplo, pode ser citada a repetição da arquitetura de edifícios com grandes superfícies refletoras e liberação excessiva de energia e a expansão da periferia geradora de sobrecarga no sistema viário.

O declínio do paradigma do subúrbio americano já é um fator considerado para adoção de novas políticas públicas por Prefeituras como a de Los Angeles, que criou incentivos para a reocupação do centro. Morar no centro passou a ser interessante com o lançamento de 
6 O conceito Smart Growth, nos Estados Unidos foi desenvolvido pela Sustainable Communities Network (SCN) e busca substituir o modelo de subúrbio periférico e de baixa densidade pelo modelo de comunidade sustentável e cidade compacta. Texto extraído do sumário executivo Why Smart Growth: A Primer pela International City/County Management Association de Geoff Anderson, Julho de 1998. empreendimentos cuja propaganda baseou-se na proximidade do emprego. $\mathrm{O}$ alto custo da infraestrutura urbana fez com que o poder público buscasse o modelo de cidade compacta e sustentável do ponto de vista ambiental, econômico e social.

No final da década de 90 surgem conceitos como o de Smart Growth ${ }^{6}$, que tem como dez princípios:

- Criar oportunidades variadas para habitação, com oferta de opções de tipologias;

- Criar bairros que possam ser percorridos a pé;

- Encorajar a colaboração entre stakeholders e comunidade;

- Fomentar a implantação de espaços atrativos com forte senso de lugar;

- Tomar decisões relativas a empreendimentos com ótimo custo benefício e justas;

- Diversificar o uso do solo;

- Preservar espaços livres, áreas ambientalmente críticas e a beleza natural;

- Prover escolhas de transporte;

- Fortalecer e direcionar empreendimentos para ocupações existentes;

- Tirar vantagem do projeto compacto de edifícios (FARR, 2008, p.30).

Com a necessidade da criação de parâmetros, surgem na década de 90 as primeiras certificações ambientais que criam padrões de comparação entre os projetos e analisam a qualidade através de um sistema de pontuação. Se a eficiência destes sistemas for comprovada, delas podem derivar diretrizes inéditas como contribuição para a legislação ambiental e urbanística.

No mercado privado estas certificações têm cunho competitivo. Os selos verdes conquistados são amplamente divulgados e usados como ferramenta de marketing e propaganda. Entretanto, o edifício denominado “verde”,isoladoe cercado por um estacionamento 
pavimentado de grande escala, como é o caso da Arena Corinthians, o Itaquerão, não é de fato positivo para o meio ambiente. A intervenção precisa ser mais ampla e ultrapassar os limites do lote. As certificações LEED ND, Neighborhood Development, desenvolvimento de bairro, e LabVerde do laboratório de mesmo nome da FAUUSP e liderado pela Professora Doutora Maria de Assunção Ribeiro Franco já incorporam o conceito mais amplo em seu sistema partindo de uma análise regional.

\section{SOBRE OS CAPÍTULOS}

Esta tese é dividida em partes. A Parte I “Desenho Urbano na direção da Sustentabilidade”, nos capítulos 1 e 2, trata do corpus teórico da tese e traz conceitos de movimentos que tratam a relação da paisagem com o desenvolvimento urbano e da definição adotada de paisagem. $O$ capítulo 1 discorre sobre a definição de Crescimento Inteligente, Smart Growth, que surge nos Estados Unidos no final do século XX criada pela organização SCN - Sustainable Community Network, como reação ao modelo em decadência do subúrbio americano e a busca pela sustentabilidade no modelo da cidade compacta europeia. Cresce o movimento denominado Novo Urbanismo aliado ao conceito do Crescimento Inteligente. Deriva da ideia de que a raiz do planejamento das cidades está no sistema de paisagem regional que engloba a área rural, as áreas de proteção, o traçado dos cursos d'água, a topografia, a geomorfologia e a partir daí prioriza as áreas destinadas ao desenvolvimento urbano. O capítulo também trata de um segundo movimento chamado Urbanismo Paisagístico, Landscape Urbanism, que defende a paisagem como elemento estruturador das quadras urbanas em substituição ao edifício. $O$ movimento evolui para o Urbanismo Sustentável e posteriormente ao Urbanismo Ecológico. O capítulo 2 discorre sobre o conceito de paisagem, sua mutabilidade e as interfaces com a ocupação urbana.

A Parte II “A InfraestruturaVerde no Projeto dos Bairros” trata do conceito e da consolidação da Infraestrutura Verde nas cidades como estratégia na escala dos bairros que contribui para que eles se transformem em bairros ecológicos, tanto na criação de áreas verdes contínuas, sejam elas remanescentes de áreas florestais, espaços públicos ou jardins comunitários, como nos sistemas de alto desempenho de drenagem natural. O capítulo 3 trata do conceito de 
infraestrutura verde e o resultado da soma de novas estratégias como meio para se atingir o equilíbrio entre ocupação e suporte físico. Mais do que isso, amplia a necessidade da percepção da paisagem em escala regional como parte desta infraestrutura. $O$ entendimento da ecologia torna-se fundamental para entender sua importância e comportamento no meio urbano.

O capítulo 4 discorre sobre ações concretas na estruturação da infraestrutura verde urbana. Além do cunho ambiental, os projetos de jardins comunitários apresentados são de cunho socioeconômico extremamente importante e testam na escala local protótipos capazes de promover a sustentabilidade na escala do bairro. A agricultura urbana toma partido de áreas potenciais já consolidadas e através de sua atividade promove a cidadania, a educação ambiental e a ampliação da rede de áreas verdes, importantes na formação de corredores ecológicos e conexão de fragmentos florestais. Pequenas praças, áreas livres de instituições, parques de vizinhança constituem a paisagem e melhoram a qualidade de vida. A produção não é capaz de suprir em escala local as necessidades de consumo da população, mas durante o seu processo beneficia toda comunidade.

O capítulo 5 apresenta estudos de caso centrados nas cidades de Los Angeles e Seattle como iniciativas do poder público para incentivar a implantação do Urbanismo Ecológico, tendo a Prefeitura como agente condutor do processo na implantação da infraestrutura verde urbana, centrado no gerenciamento de áreas verdes e sistemas de alto desempenho de drenagem natural.

A Parte III “Estádios como elementos catalisadores de transformação urbana, oportunidades para o surgimento do Urbanismo Ecológico", trata do impacto de grandes equipamentos esportivos no tecido urbano, com a transformação de sua dinâmica social, ambiental e econômica. No capítulo 6, apresentam-se estudos de caso em São Francisco com a implantação do AT\&T Park, estádio de beisebol e do STAPLES Center em Los Angeles e o seu impacto ambiental positivo nos bairros em que se inserem.

O capítulo 7 discorre sobre a perda de oportunidade na requalificação do estádio Soccer City em Nasrec na África do Sul. Apesar de a Prefeitura ter investido em infraestrutura de transporte público, os planos de recuperação ambiental não se concretizaram e imensos 
vazios urbanos foram criados ao redor do estádio durante a Copa do Mundo de 2010. Os espaços vazios do bairro permanecem até os dias de hoje.

O capítulo 8 tem como foco o bairro de ltaquera, onde hoje acontece a construção da Arena Corinthians, que reúne questões históricas, sociais, culturais e ambientais importantes no seu entorno: a agricultura proveniente das chácaras da colônia japonesa no início da construção do bairro, o sistema de trânsito e transporte coletivo estratégico para a zona leste, o desenho do sobrado da periferia replicado em diversas quadras juntamente com conjuntos habitacionais e a própria arena de futebol denominada "verde". Será a arena o elemento catalisador capaz de transformar o bairro dormitório em um exemplo de Urbanismo Ecológico? 


\section{PARTE I: \\ DESENHO URBANO NA DIREÇÃO DA SUSTENTABILIDADE}




\section{CAPÍTULO 1}

OS CONCEITOS DE CRESCIMENTO INTELIGENTE, URBANISMO PAISAGÍSTICO E URBANISMO ECOLÓGICO

\subsection{SMART GROWTH, CRESCIMENTO INTELIGENTE}

1.1.1 PRINCÍPIOS REGIONAIS

1.1.2 O PLANO REGIONAL

1.1.3 O TRANSPORTE REGIONAL

1.1.4 O BAIRRO E SUA PAISAGEM NATURAL

1.1.5 O BAIRRO E SEUS ELEMENTOS

1.1.6 O PROJETO DE UM BAIRRO E SUA ESTRUTURA

1.1.7 AS RUAS

1.1.8 OS EDIFÍCIOS

1.2 LANDSCAPE URBANISM, URBANISMO PAISAGÍSTICO

1.3 ECOLOGICAL URBANISM, URBANISMO ECOLÓGICO

1.3.1 DENSIDADE

1.3.2 OS CORREDORES SUSTENTÁVEIS

1.3.3 BAIRROS ECOLÓGICOS

1.3.4 ESPAÇOS LIVRES, ELEMENTOS DA INFRAESTRUTURA VERDE

1.3.4 OS EDIFÍCIOS VERDES E A INFRAESTRUTURA DE ALTO DESEMPENHO

1.3.6 ESTUDO DE CASO HIGH POINT SEATTLE

1.4 PLANEJAMENTO AMBIENTAL E O CASO DA CIDADE DE SÃO PAULO 


\subsection{SMART GROWTH, CRESCIMENTO INTELIGENTE}

O Smart Growth, traduzido pela autora como Crescimento inteligente, surge nos Estados Unidos no final do século XX criado pela organização SCN - Sustainable Community Network como reação ao modelo em decadência do subúrbio americano e a busca pela sustentabilidade no modelo da cidade compacta europeia.

O movimento contra a expansão do subúrbio inicia-se como uma crítica estética e social e evolui para atuar a favor da ciência. No seu livro The Smart Growth Manual, Andres Duany, Jeff Speck e Mike Lydon, embora não apresentem dados oficiais, relacionam a forma de ocupação do território com a eliminação de florestas, a construção massiva de vias e a redução de terras agriculturáveis próximas às cidades. Segundo os autores, os climatologistas relacionam o crescimento do subúrbio como um dos fatores que contribui para o aquecimento global, para a baixa qualidade do ar e a poluição das águas, e o uso diário do automóvel refletese, segundo autoridades da saúde pública americana, na epidemia de obesidade e diabetes no país.

O uso do solo pouco diversificado, a infraestrutura viária como elemento estruturador principal das cidades e a falta de investimentos na qualidade do ambiente urbano são reflexos de políticas públicas responsáveis por agravar este quadro. O conceito do Crescimento Inteligente é interessante do ponto de vista de sua aplicabilidade na legislação urbanística que rege o uso e a ocupação do solo urbano. Em seguida, apresentam-se algumas diretrizesselecionadas do manual de Crescimento Inteligente relacionadas com esta pesquisa (DUANY; SPECK; LYDON, 2010).

\subsubsection{PRINCÍPIOS REGIONAIS}

O planejamento regional é chave, pois as atividades cotidianas das pessoas extrapolam limites municipais. Nele, deve-se considerar o projeto de corredores ecológicos, sistemas de trânsito e transporte e a criação de centralidades na escala metropolitana, além de criar mecanismos para gerenciar a qualidade do ar e da água. 
Quanto ao envolvimento comunitário, a questão não é se haverá participação comunitária no processo de decisões e sim quando e como ela irá participar. Como não há poder administrativo na escala regional, a estrutura administrativa deve contar com as associações de bairro para aproximar-se das necessidades locais. Buscar uma estrutura administrativa na escala de sua estrutura física: da metrópole, ao bairro e à quadra.

O planejamento urbano deve se basear na lógica da transição entre a zona rural e a urbana. A análise é realizada a partir de um transepto (figura1), conceito derivado da ecologia, também usado por lan McHarg, em que se representa a progressão por diversos habitats em sequência, por exemplo, dos alagados presentes na várzea às florestas dos topos de morro. Os autores do Smart Growth usam esta ferramenta como método de análise das diversas formas de habitat, assentamentos humanos, com densidades e complexidades variadas. Do meio natural à cidade, analisa-se o plantio, os recuos das edificações, a arquitetura dos edifícios, as conexões. O que ocorre em cada seção pode romper ou complementar a anterior. O conceito de sustentabilidade do meio ambiente urbano surge desta ideia.

Figura 1:

Transepto de diversas paisagens, base de estudo para o Crescimento Inteligente. Fonte: Smart Growth Manual.

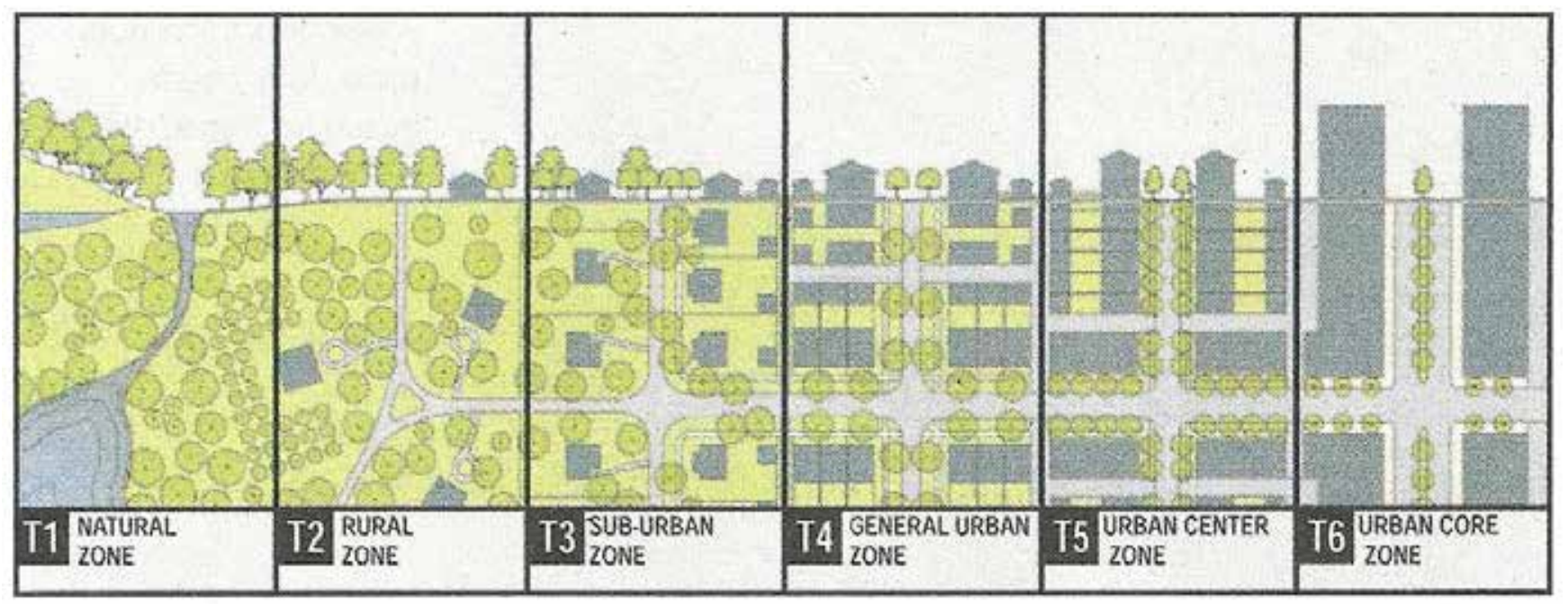

A transect provides meaningful lifestyle choices within a smart growth framework.

O Bairro tem a função de suprir grande parte das necessidades diárias de seus residentes, através de sua diversidade, compactação, de sua escala adequada ao pedestre e bem conectado com o restante da cidade. A definição de compacto, neste caso, está relacionada com o não desperdício de propriedades, por exemplo, o pedestre em 5 minutos percorre do perímetro do 
bairro à sua centralidade com caixas de rua adequadas e agradáveis. O conceito de diversidade é aplicado no sentido de possuir oferta de habitação para todas as faixas etárias, emprego, centros de compra para artigos cotidianos e possuir residentes com faixas de renda variadas tendo como reflexo a diversidade na configuração dos empreendimentos contidos no bairro. A conexão se dá através do transporte público, das vias e das ciclovias.

O poder público, principal gestor do Crescimento Inteligente, deve direcionar investimentos em áreas consideradas prioritárias. Os investimentos em infraestrutura pública e empreendimentos privados devem ser realizados em áreas onde haverá benefícios econômicos, ambientais e sociais, primeiramente com a implantação de projetos de requalificação e retrofit dentro do bairro e depois nas áreas de expansão do bairro em direção às áreas ambientalmente sensíveis (DUANY; SPECK; LYDON, 2010).

A construção de habitação social em larga escala visa suprir déficits e o ônus de concentração de pobreza. Em Maryland, por exemplo, no condado de Montgomery, todos os grandes empreendimentos precisam reservar $10 \%$ para habitação social. A localização é importante, próxima ao transporte público com fácil acesso para emprego e serviços.

A legislação de uso do solo deve prever locais para instalação de aterros, transformadores de energia com profunda análise do uso do solo existente e das condições de transporte, tendo a justiça social como princípio norteador de sua implantação, para que não agrave a segregação espacial (DUANY; SPECK; LYDON, 2010).

\subsubsection{PLANO REGIONAL}

Para elaboração do plano regional, o Crescimento Inteligente lista alguns passos principais a serem seguidos. $O$ primeiro deles consiste em mapear as áreas verdes mais significativas a fim de guiar a expansão dos centros urbanos. Dentre os elementos da paisagem a serem mapeados foram identificados: alagados e suas áreas de amortecimento, várzeas, encostas moderadas e íngremes, áreas para recarga de aquíferos, florestas, áreas de produção agrícola, habitat selvagem significativo, sítios culturais, históricos e arqueológicos e áreas de interesse contemplativo do sistema viário (DUANY; SPECK; LYDON, 2010). 
O próximo passo consiste em separar, dentro do mapeamento das áreas verdes aquelas já protegidas por lei para expansão urbana, ou seja, no Brasil, isso fica definido no Plano Diretor Municipal através da delimitação do perímetro urbano. Através deste mapeamento é possível delinear estratégias para a proteção dos espaços livres das áreas rurais a fim de criar um sistema contínuo de corredores naturais em áreas importantes para a fauna e de fragilidade ambiental.

Além disso, o mapeamento permite traçar áreas disponíveis para expansão urbana dentro de uma estrutura mais racional e em sincronia com a capacidade de suporte físico. Primeiro, desenvolvem-se as áreas subutilizadas dentro da malha urbana, áreas contaminadas brownfields, e próximas aos terminais intermodais. Depois, as áreas de crescimento controlado como áreas do perímetro da expansão urbana e áreas vazias periféricas. Em seguida, áreas de crescimento restrito como novos empreendimentos periféricos em áreas já dotadas de infraestrutura. Por último, o mapeamento de áreas integralmente protegidas de ocupação, sem infraestrutura e em áreas ambientalmente sensíveis (DUANY; SPECK; LYDON, 2010).

Apesar de o plano ser destinado à região, é importante mapear a estrutura dos seus bairros e dentro deles as áreas de interesse regional, local e principais corredores. As áreas do território de uso exclusivo como polos industriais, centros médicos, institucionais, terminais intermodais devem ser estudadas para que se conectem com outros usos diversificados.

Os corredores naturais e construídos pelo homem, o sistema viário, devem ser projetados de forma a permitir ao longo das vias o uso diversificado servido por transporte público. Os corredores naturais, sejam eles constituídos de florestas ou de cursos d'água, servem de orientadores da expansão, a fim de se preservar e minimizar conflitos com a ocupação.

\subsubsection{O TRANSPORTE REGIONAL}

O Crescimento Inteligente incorpora em seus princípios o papel fundamental que o transporte exerce sobre a morfologia das comunidades. Decisões referentes a ele não podem ser descoladas do uso do solo. É preciso buscar um equilíbrio entre os diversos modais a fim de facilitar a mobilidade e promover a formação de bairros autossuficientes (DUANY; SPECK; LYDON, 2010). 
Historicamente, a expansão urbana se deu ao longo de ferrovias e as estações de trem constituíam-se nos principais pontos nodais de uma região. No entanto, com o advento do automóvel, permitiu-se não só nas cidades americanas como também nas cidades brasileiras, a ocupação linear e indisciplinada, que cortou a paisagem sem a conexão entre transporte e uso do solo para direcionar o seu crescimento, resultando na urbanização de áreas protegidas.

O privilégio do transporte individual sobre o coletivo, no sistema de mobilidade urbana gera congestionamentos e perdas. Nos Estados Unidos investe-se quatro vezes mais na construção de vias do que na infraestrutura de transporte coletivo. O Crescimento Inteligente busca o modelo oposto com o equilíbrio destes investimentos, a fim de diminuir custos, tempo de deslocamento e, por consequência, melhorar a qualidade de vida urbana.

Sistemas de trânsito e transportes projetados na escala regional são mais eficientes. Cidades que possuem políticas públicas de planejamento neste sentido são NovaYork, Chicago e Washington D.C. A cidade de Portland tem um dos planos de transporte considerados mais eficientes dos Estados Unidos, que direcionou o desenvolvimento de uso misto no entorno de pontos de parada de trens de superfície, chamados Lightrails (figura 2). Mesmo antes do início de novos empreendimentos, são identificados os centros de bairro e previstos projetos de bulevares largos, suficientes para acomodar uma linha de trem ou corredores de ônibus Bus RapidTransit (BRT), a fim de se evitar a necessidade de desapropriações futuras e certamente necessárias e onerosas. 
Figura 2:

Sistema de transporte sobre trilhos em Portland

Estados Unidos.

Foto: PriscilaTiba

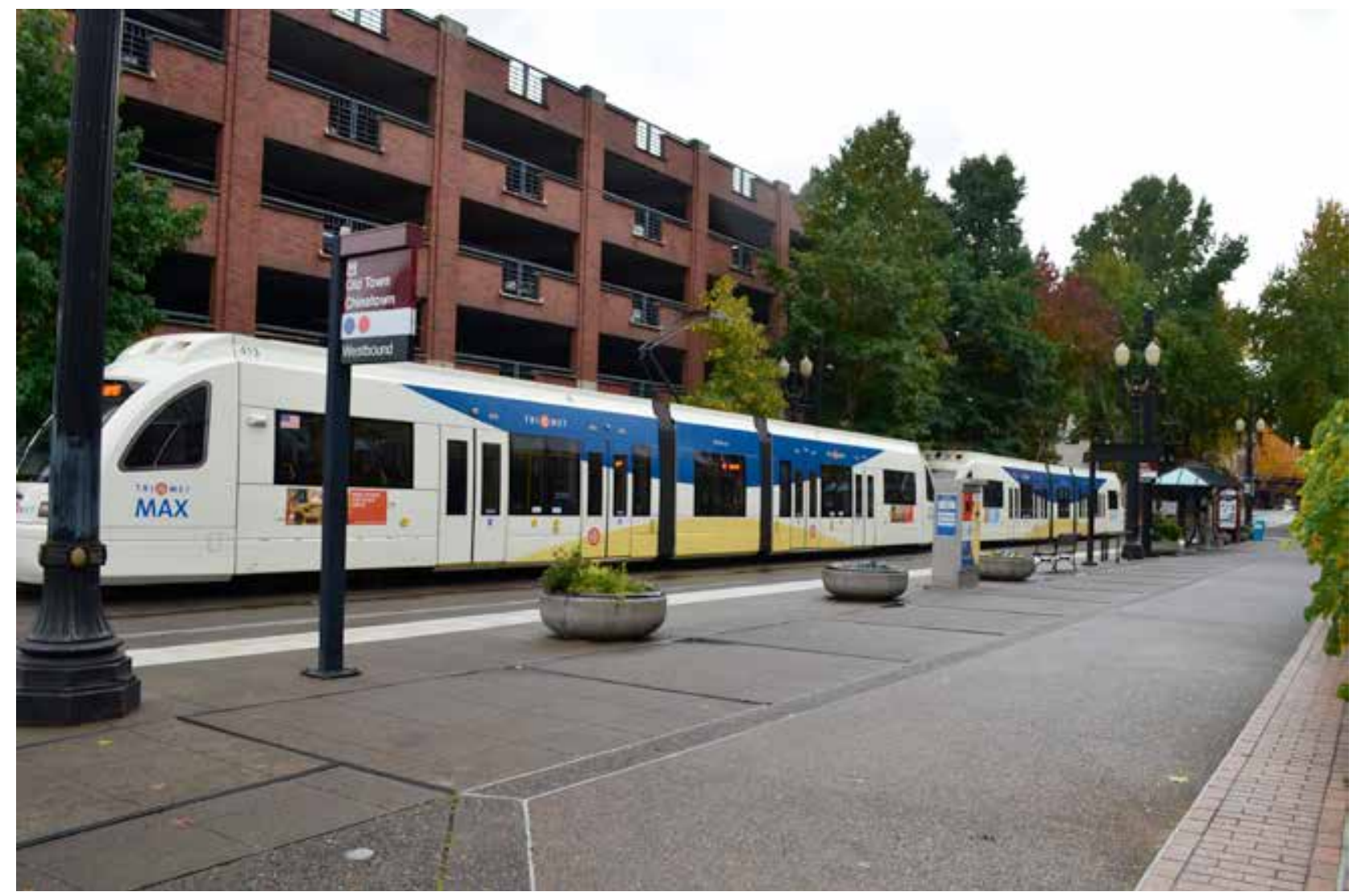

O tráfego de veículos não pode afetar negativamente a "habitabilidade" (livability) de uma área. Vias expressas não devem cortar bairros, pois prejudicam sua qualidade visual e ambiental. Os planejadores urbanos devem tornar o transporte público e os percursos a pé mais atraentes do que a opção de se dirigir um automóvel. Este conceito envolve desenho de calçadas, frequência de linhas, arborização urbana em detrimento do projeto de expansão de vias e novas áreas para estacionamento (DUANY; SPECK; LYDON, 2010).

\subsubsection{O BAIRRO E SUA PAISAGEM NATURAL}

Ao incorporar as riquezas naturais presentes, como florestas, platôs para contemplação e vistas proporcionadas por sua topografia, a drenagem natural, os cursos d'água, os alagados e suas áreas de amortecimento no seu desenho, o bairro enriquece sua paisagem. A preservação de corredores ecológicos beneficia os animais e igualmente os seres humanos, e a presença maciça de árvores contribui para a qualidade visual e principalmente ambiental na melhoria da qualidade do ar e do microclima. 
A valorização de uma área urbana pela presença de elementos naturais provou superar o custo de sua preservação. A conservação de árvores deve ser o elemento guia de todo projeto em meio urbano. Um levantamento detalhado das árvores existentes guia a implantação de parques, praças no desenho urbano e quando não há espaço disponível, segundo a professora doutora Maria Assunção Ribeiro Franco, coordenadora do LabVerde, devem-se desconstruir as superfícies pavimentadas para que as árvores possam se desenvolver em sua plenitude em espaços públicos de maior escala ou mesmo nas vias. Esta estratégia faz parte da implantação da infraestrutura verde urbana, conceito do Urbanismo Ecológico.

A terraplenagem e o equilíbrio entre corte e aterro diminuem o impacto da ocupação em áreas verdes, pois preserva um maior número de árvores. O solo superficial deve ser retirado e armazenado para que possa ser reaproveitado no novo plantio devido à riqueza de matéria orgânica.

Ainda sobre estratégias de reuso, o Crescimento Inteligente tem como princípio a coleta e o reuso da água, especialmente em cidades localizadas em áreas onde a chuva é mais escassa. A coleta pode ser feita a partir da água que cai do telhado e em seguida armazenada em cisternas enterradas ou no próprio térreo, com a criação de lagoa de retenção superficial para as águas de drenagem. Esta segunda ainda mais interessante, pois a lagoa torna-se um elemento enriquecedor da paisagem.

Além do reaproveitamento das águas de chuva, provenientes da coleta das coberturas, outra alternativa é o reaproveitamento das águas cinzas, provenientes do chuveiro e da pia que, após tratadas, podem ser reutilizadas. Este tratamento pode-se dar através de alagados construídos (figura 3) através da filtração pelas plantas ou mesmo tratamentos químicos convencionais. A tubulação de água de reuso deve ser independente e claramente identificada. Nos Estados Unidos ela recebe uma coloração diferente das demais. 
Alagados construídos para tratamento de efluentes domésticos. Fonte: Patrícia Akinaga.

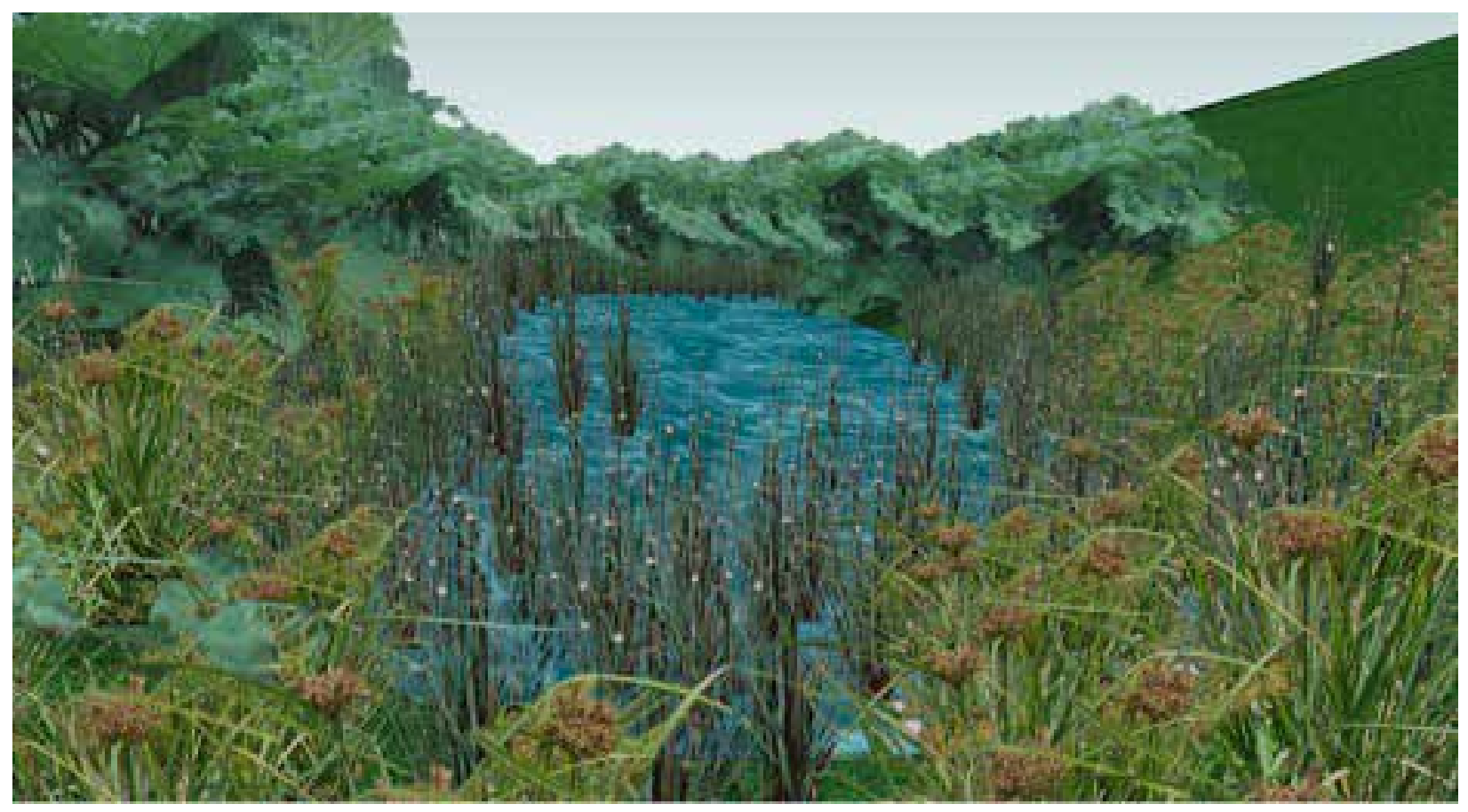

O reuso das águas no próprio lote tem o custo inferior ao do tratamento nas estações de água, conserva energia, diminui o custo do tratamento do esgoto além de se tornar, no caso da lagoa, um elemento da paisagem e uma ferramenta de educação ambiental e envolvimento comunitário.

Como parte da paisagem natural do bairro, os parques urbanos tornam-se um elemento importante. O Crescimento Inteligente reforça que todo cidadão deve ter direito ao acesso a áreas verdes. Faz parte da qualidade de vida urbana o bairro possuir um parque próximo às áreas residenciais a uma distância de cinco minutos a pé. A reserva de áreas verdes nos bairros deve fazer parte do Plano Diretor Municipal, detalhada nos planos regionais quanto a sua localização e dimensionamento.

As áreas verdes de grande escala têm uma função importante para a vida selvagem. Nas cidades, elas desempenham este papel com maior eficiência se conectadas. Os fragmentos lineares verdes de 62 metros de largura ou mais devem ser mapeados pelos planos regionais e toda vez que cruzarem vias, devem ser devidamente sinalizados para se evitar o atropelamento de animais. Para as áreas verdes contínuas de vias, com pelo menos 6 metros de largura deve-se prever travessias para pedestres para não interromper o percurso e ao mesmo tempo enriquecer a experiência (DUANY; SPECK; LYDON, 2010). 
1 LEED Neighborhood Development é a certificação LEED que considera a localização e a escala regional do Projeto elaborada pelo Green Building Council americano.

\subsubsection{O BAIRRO E SEUS ELEMENTOS}

Segundo princípios do Crescimento Inteligente, um bairro deve possuir um tecido diversificado para atender as necessidades cotidianas de seus habitantes a uma distância que possa ser percorrida a pé. Deve haver um equilíbrio entre uso misto, tipologias habitacionais variadas, áreas comerciais e institucionais. O bairro considerado mais completo provê aos pedestres acesso a escolas, creches, clubes e uma diversidade de espaços abertos onde pode haver a produção local de alimentos, conceito aprofundado no capitulo 4. Na estruturação de um bairro, devem-se buscar oportunidades para a produção de alimentos localizada em pequenas propriedades no limite do perímetro urbano. Além de fomentar o emprego, fornecem alimentos para a região, além da possibilidade da produção nos quintais das casas, seja em vasos ou mesmo na escala de tetos verdes e jardins comunitários, como parte da infraestrutura verde urbana.

A densidade mais alta possibilita a liberação de solo para usos não residenciais, como destinadas a terminais intermodais, áreas verdes e aliada à diversidade de usos, trazendo vitalidade ao tecido urbano. $O$ poder público deve criar políticas de incentivos fiscais para criar bairros mais equilibrados com diversidade de tipologias habitacionais, ruas comerciais com mix de serviços onde se estabelece o centro social do bairro (DUANY; SPECK; LYDON, 2010).

\subsubsection{O PROJETO DE UM BAIRRO E SUA ESTRUTURA}

Os bairros devem ser projetados de forma a atender a escala do pedestre, com um centro mais denso e um espaço público principal. Neste espaço é onde se concentram as atividades de lazer e cívicas da população residente e flutuante. Em Los Angeles, por exemplo, em bairros como o Hancock Park, a oito quilômetros do centro da cidade, o espaço público principal é um parque de vizinhança conectado a uma área intensa de comércio de produtos variados, mercado de alimentos na 3rd Street e entretenimento.

A LEED ND ${ }^{1}$ tem a escala de uma comunidade em complementação ao sistema de pontuação LEED, que avalia somente a escala do edifício. Foi criada pelo Congresso para o Novo Urbanismo, o Conselho de Defesa dos Recursos Naturais (The Natural Resources 
Defense Council) e o U.S. Green Building Council. Através desta ferramenta as Prefeituras, empreendedores e futuros residentes podem determinar o grau que cada projeto proposto pode incorporar princípios de Crescimento Inteligente. Para os edifícios, a LEED estabeleceu um sistema de pontuação que é adotado por alguns governos que exigem o certificado LEED para novos edifícios; espera-se que o LEED-ND possa se tornar um padrão municipal para regular o desenho urbano de empreendimentos de grande escala.

A escala adequada ao pedestre, segundo o Crescimento Inteligente, é pautada no tempo que um indivíduo percorre o bairro para satisfazer as suas necessidades diárias. O tempo ideal considerado é de 5 minutos, o chamado pedestrian shed, que tem em média 400 metros do limite ao centro do bairro, quatro quadras. Dentro destas dimensões é projetada a estrutura do bairro, ou este pode ser reestruturado e, desta forma, revelar valores históricos e culturais por vezes desconectados (DUANY; SPECK; LYDON, 2010). No caso do bairro de Itaquera em São Paulo, a construção do estádio gera transformações do seu entorno que podem culminar em um desenho estruturado a partir de um centro coincidente ao centro da arena.

O mesmo parâmetro de tempo de caminhada, mais curta, com 2 minutos, é aplicado para a escolha de terrenos adequados a instalações de pequenos parques, normalmente de 1100 metros quadrados, cujo programa inclui área pavimentada com bancos, área verde arborizada com copas expressivas e dependendo do perfil da vizinhança, um playground.

O movimento denominado Novo Urbanismo, aliado ao conceito do Crescimento Inteligente, deriva da ideia de que a raiz do planejamento das cidades está no sistema de paisagem regional, que engloba a área rural, as áreas de proteção, o traçado dos cursos d'água, a topografia, a geomorfologia e, a partir daí, prioriza as áreas destinadas ao desenvolvimento urbano. O Novo Urbanismo também incorpora Códigos de Crescimento Inteligente baseados em configuração de edifícios e não no zoneamento convencional baseado em uso do solo. As formas diferentes e escalas induzem a usos diversificados.

O centro dos bairros precisa ser estruturado para acomodar o transporte público e oferecer ambiente agradável para o pedestre. Toda viagem se inicia ou termina com um percurso a pé. Estudos mostram que os usuários andam 5 minutos a uma parada de ônibus 
e 10 minutos a uma estação de trem ou metrô. Enquanto os ônibus podem ligar centros de bairro, as estações de trem podem servir 04 bairros localizados a 10 minutos de caminhada e se transformar em um corredor de densidade mais alta, comércio e serviços (DUANY; SPECK; LYDON, 2010).

\subsubsection{AS RUAS}

As ruas devem ser organizadas em uma rede interconectada e dentro de uma hierarquia. As ruas de maiores dimensões devem conectar centralidades e dividir bairros. Dentro dos bairros, ruas locais, mais curtas e estreitas devem acomodar o tráfego caracterizado pela menor velocidade. Sempre que possível, deve-se oferecer opções de rotas, pois elas reduzem congestionamentos e também favorecem ao pedestre. Segundo os princípios do Crescimento Inteligente, um tecido urbano com quadras de menores dimensões faz com que os residentes andem mais, usem o transporte coletivo e dirijam menos (DUANY; SPECK; LYDON, 2010).

Outra forma de estimular os pedestres é evitar elementos considerados hostis aos mesmos como postos de gasolina, empenas cegas, estacionamentos de superfície nos caminhos de pedestres principais (DUANY; SPECK; LYDON, 2010).

Desde a década de 50, as ruas foram projetadas somente com o objetivo de "mover automóveis", em detrimento de pedestres e bicicletas. É importante lembrar que a rua é parte integrante do sistema de espaços públicos urbanos e um elemento importante da infraestrutura verde urbana. Seu projeto deve ser resultado de um esforço conjunto e multidisciplinar envolvendo urbanistas, arquitetos paisagistas, engenheiros e representantes das concessionárias e infraestrutura tradicional. As chamadas Ruas Completas (Complete Streets) possuem faixas de rolamento mais estreitas, ciclovia, bicicletários, estacionamento paralelo ou em 45 graus, cobertura vegetal ritmada e contínua, calçadas amplas, mobiliário urbano e iluminação adequados.

A velocidade dos veículos é fator importante para a segurança e conforto dos pedestres. O desenho das ruas auxilia na redução da velocidade através do projeto de pistas 
mais estreitas, evitando-se vias muito retas e longas e provendo faixas de estacionamento paralelo. O estacionamento na rua oferece muitos benefícios, além de reduzir a velocidade dos motoristas, protege os pedestres do tráfego como barreira física entre a via e a calçada, diminui a necessidade de estacionamentos nos lotes, e consequentemente, áreas pavimentadas e aumenta a circulação de pessoas nas calçadas. Dependendo do uso do solo e da densidade, deve ser previsto nos dois lados da via, por exemplo, em áreas comerciais onde é recomendado, o estacionamento em 45 graus para acomodar um maior número de usuários e consumidores.

As ruas de sentido único facilitam o tráfego de veículos, mas, como resultado, diminuem a segurança de pedestres, pois a ausência de tráfego no sentido oposto faz com que os motoristas fiquem menos atentos e mais velozes. Além disso, prejudicam o comércio, pois o movimento é maior apenas em um período do dia e aumentam distâncias a serem percorridas. Pode-se justificar o seu projeto em áreas de densidade alta (DUANY; SPECK; LYDON, 2010).

Dentro da hierarquia viária, as avenidas e bulevares são vias de alta capacidade e que conectam, na maior parte, centros de bairros ou tangenciam o seu perímetro. Possuem canteiro central largo, plantado, que varia de 3 a 6 metros de largura tornando-se ambiente ideal para o plantio de árvores de grande porte e por sua vez elementos importantes da infraestrutura verde urbana. Em um contexto urbano consolidado, uma estratégia importante é procurar oportunidades para ampliação de áreas verdes que podem ou não estar associadas ao sistema viário.

As calçadas deveriam ser projetadas como as vias, sendo propriamente dimensionadas de acordo com o fluxo de pedestres tendo, no mínimo, 3 metros de largura. Em áreas comerciais não seria exagero pensar em dimensões entre 5 e 8 metros, que possibilita, além da circulação, a criação de áreas de estar com bancos e eventualmente mesas e cadeiras produzindo vitalidade. Em ruas locais, a dimensão mínima da calçada é de 1,50 metros que acomoda duas pessoas caminhando lado a lado, entretanto, larguras mais generosas proporcionam um espaço de interação mais adequado e interessante (DUANY; SPECK; LYDON, 2010).

As árvores podem ser plantadas em canteiros contínuos ou caixas individuais e proporcionam conforto ao pedestre e melhoria ao sistema de drenagem natural como no caso dos jardins de chuva dos bairros de Portland e Seattle, nos Estados Unidos. As árvores reduzem 
a velocidade de tráfego de veículos, diminuem a formação de ilhas de calor e seus efeitos e filtram os poluentes do ar. É importante que sejam selecionadas espécies adequadas quanto ao seu sistema radicular e porte para que não causem conflitos com os demais equipamentos de infraestrutura. $\mathrm{O}$ fato é que as árvores fazem parte da infraestrutura urbana assim como postes, transformadores, elementos de mobiliário urbano, não só do ponto de vista da qualidade visual, tratando-se de qualidade de vida do ambiente urbano.

\subsubsection{OS EDIFÍCIOS}

Os gabaritos dos edifícios, bem como seu recuo variam de acordo com a característica da rua. Para o Crescimento Inteligente, fachadas de apenas um pavimento não resultam em uma relação forte com a rua e devem ser evitadas em área de centralidades. Arranha-céus, por sua vez, só devem ser projetados em centros de metrópoles, a fim de se evitar a absorção excessiva de uso em apenas um lote e a produção de lotes vazios ou subutilizados e usos como estacionamentos, já que a demanda não pode ser absorvida apenas pelas vagas das ruas. Para a revitalização de uma área, o ideal é o projeto de edifícios de até quatro pavimentos e que atraiam uma diversidade de empreendedores e por consequência diversidade de empreendimentos e público alvo (DUANY; SPECK; LYDON, 2010).

Outro aspecto importante a ser observado no projeto dos edifícios é a transparência de sua fachada, ou seja, sem muros e cercas altas que dificultem a visibilidade de dentro para fora do lote e vice-versa. É uma ferramenta importante de segurança pública e que adiciona qualidade de vida.

Assim como o movimento denominado Novo Urbanismo, o conceito do Crescimento Inteligente descreve os edifícios através da forma e não do tipo de uso. Um segundo movimento chamado Landscape Urbanism, Urbanismo Paisagístico, adota a paisagem como elemento estruturador das quadras urbanas em substituição ao edifício. 


\subsection{LANDSCAPE URBANISM, URBANISMO PAISAGÍSTICO}

O Urbanismo Paisagístico tem no seu desenho urbano a paisagem como ponto de partida. Segundo o autor Frits Palmboom, no seu livro Drawing the ground - Landscape Urbanism today, a cidade é "amarrada" ao seu suporte físico e condicionada a sua situação, portanto, não totalmente manipulada pelo projeto. A cidade se transformou na paisagem urbanizada $e$ o solo é o primeiro elemento que sofre intervenção para que possa receber as edificações. A relação entre arquitetura, urbanismo e arquitetura paisagística pode ser orquestrada e flexível com o objetivo de atingir uma sinergia na estrutura e na estética dos projetos.

Dentro deste conceito, o Urbanismo Paisagístico surge como uma nova disciplina nos Estados Unidos na segunda metade da década de 90. No seu "Reference Manifesto", Charles Waldheim o descreve como "o realinhamento disciplinar no qual a paisagem substitui a arquitetura como o bloco de construção do urbanismo contemporâneo." (WALDHEIM, 2006, tradução nossa). A paisagem torna-se a lente pela qual a cidade é representada e o meio pelo qual é construída. A visão é que o desenho da cidade deve ser orientado pelo processo e não pela forma, ao contrário do que defende o movimento Novo Urbanismo.

Em seu artigo "Terra Fluxus", publicado no livro Landscape Urbanism Reader, James Corner, arquiteto paisagista do escritório Field Operations, responsável pelo projeto do parque Highline em Nova York, discorre sobre o escopo da arquitetura paisagística como modelo para o urbanismo, englobando técnicas em grande escala junto ao projeto, a expressão cultural e a formação ecológica. Segundo ele, recentemente, alguns arquitetos paisagistas expandiram suas habilidades no campo do urbanismo e da infraestrutura, tendo a paisagem posição central no foco das análises e ponto de partida do qual o urbanismo se desenvolve.

O termo Landscape Urbanism sintetiza e representa o movimento no qual se enquadram estes profissionais, uma nova disciplina apresentada no Simpósio de Landscape Urbanism em 1997, organizado por Charles Waldheim. No século XIX, a paisagem era vista como antagônica à cidade. Enquanto as cidades são constituídas de edifícios, infraestrutura de transportes e os efeitos indesejáveis de poluição, congestionamentos e outras formas de estresse social, a paisagem surge em forma de parques, áreas verdes, arborização viária, esplanadas e jardins; como uma espécie de alívio aos efeitos da urbanização. Um exemplo disso é o Central Park 
em Nova York, intencionalmente projetado para ser o respiro de Manhattan e que se tornou elemento de valorização imobiliária de seu entorno, o que o aproxima do modelo de Landscape Urbanism, onde a paisagem orienta o processo de construção da cidade, trazendo com ela civilidade, saúde, igualdade social e desenvolvimento econômico.

Além de melhorar a estética urbana, as áreas verdes presentes nas cidades possuem a capacidade de abrigar funções ecológicas importantes como a drenagem e a melhoria da qualidade do ar. O autor exemplifica através do sistema de águas pluviais sob a estrutura do Boston Back Bay Fens e dos corredores verdes de Stuttgart pelos quais percorre o ar fresco das montanhas com a função de baixar temperaturas e limpar o ar da cidade. Esta infraestrutura verde tem função importante para a saúde dos habitantes e para a qualidade de vida nos centros urbanos. Estes precedentes, segundo Corner, demonstram o potencial do Landscape Urbanism e a forma como varia de escala e coloca o tecido da cidade no seu contexto regional e biótico de projetar as relações entre os processos dinâmicos do meio ambiente natural e a forma urbana.

Sem dúvida, a paisagem natural agrega qualidade estética às cidades, entretanto, sua função, como infraestrutura verde é mais importante. Os arquitetos paisagistas criticam como o desenho da cidade negligenciou a natureza que só pode ocupar o espaço residual, produto da forma de ocupação. Esta relação permanece problemática, ao passo que os conflitos gerados por ela determinam a urgência com que a recuperação do meio ambiente natural é necessária para mitigá-la.

No início do século $X X$, apenas dezesseis cidades no mundo tinham mais do que um milhão de habitantes, no entanto, no final do mesmo século mais de quinhentas cidades tinham mais de um milhão de residentes, sendo muitas delas, com mais de dez milhões de habitantes e ainda em crescimento (WALDHEIM, 2006). Baseados nisso, planejadores urbanos e arquitetos não podem mais negligenciar a natureza em um contínuo processo em que ela só dá lugar à ocupação urbana; ao contrário, ela precisa fazer parte da estrutura da cidade. 
2 Extraído do livro Sustainable Urbanism, Urban Design with Nature, FARR, Douglas, 2006, pag. 100. Dados da ONU da revisão de 2004 do Departamento de Assuntos Econômicos e Sociais. Disponível em: <http://www.un.org/newpress/ docs/2005/pop918.doc.htm>. Acesso em: 11 nov. 2000.

\subsection{ECOLOGICAL URBANISM, URBANISMO ECOLÓGICO}

Segundo o arquiteto paisagista Douglas Farr, o Urbanismo Ecológico, denominado por ele como Sustentável, cria o cenário para um novo estilo de vida, mais equilibrado, resultante da junção do movimento do Crescimento Inteligente, Novo Urbanismo, e Edifícios e Infraestrutura Verdes. Centros urbanos projetados a fim de proporcionar uma qualidade de vida mais elevada, com o atendimento das necessidades cotidianas para os residentes, que se deslocam primordialmente a pé ou através do transporte público.

O autor define o Urbanismo Ecológico como o urbanismo de escala adequada ao pedestre, servido de transporte público e integrado com edifícios de alto desempenho e infraestrutura de alto desempenho. Os princípios fundamentais do Urbanismo Ecológico baseiam-se na cidade compacta, densa e no acesso do homem à natureza (biophilia), com cinco atributos principais: definido, compacto, completo, com conexões e biophilia. A compacidade e a biophilia também são atributos dos corredores sustentáveis (FARR, 2006, p.42).

O Urbanismo provê a base para os assentamentos humanos sustentáveis, no entanto, o que se nota mesmo no Novo Urbanismo é a colocação de esgotos e águas pluviais juntos enterrados em tubulações, edifícios ineficientes do ponto de vista energético, águas pluviais de superfície sem tratamento, ilhas de calor urbanas, ausência de áreas verdes expressivas e uma dependência completa global de recursos energéticos, alimentos e outros recursos. Nos próximos 45 anos a população global crescerá em 2.6 bilhões de pessoas, sendo a maior parte delas habitantes das cidades ${ }^{2}$. O Urbanismo torna-se ferramenta importante para a ocupação mais equilibrada com os recursos naturais, fortalecendo a adoção do Urbanismo Ecológico.

Para guiar gestores e arquitetos no desenvolvimento do Urbanismo Ecológico, Douglas Farr criou diretrizes e estratégias de origem interdisciplinar. Como exemplo, o arquiteto cita o compartilhamento de automóveis como forma de se minimizar a necessidade de estacionamentos e criar oportunidades para maior densidade. Farr divide as diretrizes em categorias: densidade, corredores sustentáveis, bairros ecológicos, o acesso do homem à natureza e edifícios e infraestrutura verde de alto desempenho. O objetivo é criar lugares que integram o homem aos sistemas naturais. 


\subsubsection{DENSIDADE}

Densidade é um elemento importante do Urbanismo Ecológico, que gera benefícios locais, regionais e globais. Bairros densos e diversificados geram menos viagens per capita e criam oportunidades, liberam o solo para áreas verdes que adicionam qualidade ambiental e de vida aos centros urbanos. Em relação à água, empreendimentos mais densos "impermeabilizam" menos o solo, resultando em uma qualidade melhor para as águas pluviais de superfícies que são filtradas até atingir os rios e córregos. Como técnicas, para não afetar de forma negativa as bacias hidrográficas, podemos citar os jardins de chuva, as lagoas de retenção e as biovaletas da infraestrutura verde. Em áreas já consolidadas a infraestrutura verde pode ser implantada nas ruas, nos telhados, em vazios urbanos e áreas subutilizadas.

\subsubsection{OS CORREDORES SUSTENTÁVEIS}

Os Corredores Sustentáveis são constituídos por corredores de trânsito e transporte e corredores ecológicos. (FARR, 2006)

Um ponto chave para o desenho de corredores de trânsito e transporte é a integração do sistema de transporte com o uso do solo e a tecnologia, juntamente com o investimento sólido na rede de transporte público, a fim de minimizar o uso do automóvel e os deslocamentos diários. Segundo Shelley Poticha, da entidade Reconnecting America, o desejo de se melhorar a acessibilidade e ter opções para habitação e meios de transporte resultou no surgimento de empreendimentos direcionados pelo transporte,TOD, transit oriented developments, em que a moradia fica localizada a poucos minutos a pé de estações de metrô, trem e terminais de ônibus. 
Figura 4:

Diagrama de Corredores Sustentáveis de Douglas Farr, Leslie Oberholtzer Christian Schaller (tradução nossa)

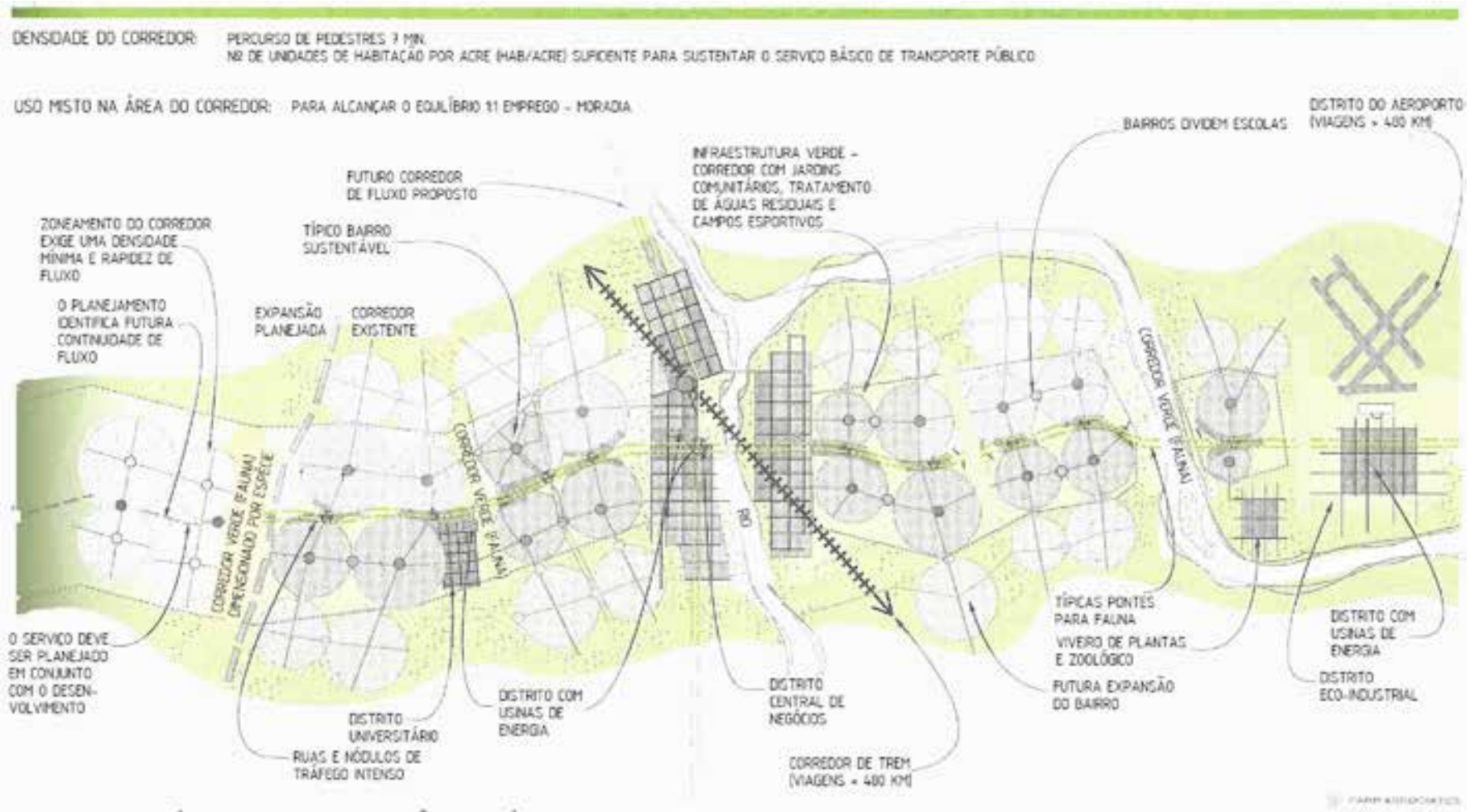

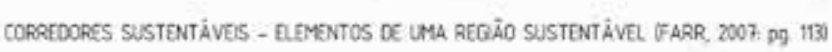

A urbanização crescente, a perda de habitat e a fragmentação de áreas verdes geraram ameaças para a conservação da vida selvagem. Biólogos, nos últimos 20 anos, têm desenvolvido estudos para determinar como o tamanho, a forma e a conectividade dos habitats afetam as dinâmicas das espécies e dos processos naturais. Instituições como o Environmental Law Institute fornecem recomendações para o dimensionamento de fragmentos para garantir sua função ecológica bem como zonas de amortecimento, conexão entre fragmentos e o percentual de habitat em áreas urbanas a fim de dar apoio a espécies, comunidades e à diversidade dos ecossistemas (tabela 1.1).

O uso do solo e sua relação com a paisagem natural é determinante para a viabilidade de fragmentos florestais, a quantidade de habitat adequado, os efeitos de borda e a eficiência de zonas de amortecimento e corredores ecológicos. Sob este ponto de vista, paisagens urbanas bem projetadas abrigam grandes fragmentos, de alta qualidade e conexões a fim de acomodar populações sustentáveis de espécies nativas; corredores ecológicos definidos para conectar grandes fragmentos isolados e zonas de amortecimento largos e verdes para minimizar os efeitos de borda e a transição entre áreas ocupadas e preservadas (figura 4). 
Tabela 1.1

Parâmetros de conservação para o planejamento do

Environmental Law Institute FARR, 2006, P. 123 (tradução nossa)

\section{PARÂMETROS DE CONSERVAÇÃO PARA O PLANEJAMENTO dO ENVIRONMENTAL LAW INSTITUTE}

\begin{tabular}{|c|c|c|c|c|c|}
\hline & $\begin{array}{l}\text { Percentual de } \\
\text { habitat adequado }\end{array}$ & $\begin{array}{l}\text { Dimensões para o } \\
\text { habitat de um } \\
\text { fragmento }\end{array}$ & Conexões & $\begin{array}{l}\text { Zona de } \\
\text { amortecimento } \\
\text { para vegetação } \\
\text { ripária }\end{array}$ & $\begin{array}{l}\text { Largura da zona de } \\
\text { amortecimento de } \\
\text { borda }\end{array}$ \\
\hline Padrão & $\begin{array}{l}\text { Mínimo de } 20 \% \text { a } \\
60 \% \text { de habitat } \\
\text { natural. Varia de } \\
\text { acordo com as } \\
\text { espécies e a } \\
\text { qualidade }\end{array}$ & $\begin{array}{l}\text { Mínimo de } 55,64 \\
\text { hectares, depende } \\
\text { das espécies. } \\
\text { Planejadores devem } \\
\text { consultar biólogos } \\
\text { locais }\end{array}$ & $\begin{array}{l}\text { A condição da } \\
\text { paisagem do } \\
\text { entorno, a distância } \\
\text { entre fragmentos e } \\
\text { o projeto do } \\
\text { corredor afeta a } \\
\text { habilidade de } \\
\text { espécies de se } \\
\text { dispersar pela } \\
\text { paisagem }\end{array}$ & $\begin{array}{l}\text { Mínimo: } 100 \\
\text { metros para } \\
\text { conservação da } \\
\text { vida selvagem. } \\
\text { Varia de } 3 \text { metros a } \\
2500 \text { metros e } \\
\text { depende das } \\
\text { espécies, das } \\
\text { condições do } \\
\text { terreno e da bacia } \\
\text { hidrográfica, usos } \\
\text { do solo adjacentes, } \\
\text { declividades, } \\
\text { hidrologia e } \\
\text { objetivos de } \\
\text { gerenciamento }\end{array}$ & $\begin{array}{l}\text { Mínimo: } 250 \text { a } 330 \\
\text { metros. Os efeitos } \\
\text { de borda em } \\
\text { fatores abióticos } \\
\text { podem se estender } \\
\text { de } 10 \text { a } 250 \text { metros. } \\
\text { Medidas devem ser } \\
\text { tomadas para } \\
\text { minimizar os } \\
\text { efeitos de borda } \\
\text { sobre os } \\
\text { fragmentos. }\end{array}$ \\
\hline Pássaros & $\begin{array}{l}\text { Literatura varia de } \\
5 \% \text { a } 80 \%\end{array}$ & $\begin{array}{l}\text { Literatura varia de } 1,0 \\
\text { a } 2,50 \text { hectares }\end{array}$ & $\begin{array}{l}\text { Mantém conexão } \\
\text { entre fragmentos } \\
\text { na paisagem }\end{array}$ & $\begin{array}{l}\text { Literatura varia de } \\
15 \text { metros a } 1.700 \\
\text { metros }\end{array}$ & $\begin{array}{l}\text { Literatura varia de } \\
53 \text { a } 704 \text { metros } \\
\text { depende do } \\
\text { parâmetro medido }\end{array}$ \\
\hline Mamíferos & $\begin{array}{l}\text { Literatura varia de } \\
6 \% \text { a } 30 \% \text { para } \\
\text { pequenos } \\
\text { mamíferos. }\end{array}$ & $\begin{array}{l}\text { Literatura varia de } \\
1,01 \text { a } 2,18 \text { milhões } \\
\text { de hectares }\end{array}$ & $\begin{array}{l}\text { Mantém conexão } \\
\text { entre fragmentos } \\
\text { na paisagem }\end{array}$ & $\begin{array}{l}\text { Literatura varia de } \\
30 \text { a } 200 \text { metros }\end{array}$ & $\begin{array}{l}\text { Literatura varia de } \\
45 \text { a } 900 \text { metros } \\
\text { para apenas } 3 \\
\text { espécies }\end{array}$ \\
\hline $\begin{array}{l}\text { Répteis e } \\
\text { anfíbios }\end{array}$ & $\begin{array}{l}\text { Consultar biólogos } \\
\text { locais para } \\
\text { informação } \\
\text { específica }\end{array}$ & $\begin{array}{l}\text { Consultar biólogos } \\
\text { locais para } \\
\text { informação } \\
\text { específica }\end{array}$ & $\begin{array}{l}\text { Mantém conexão } \\
\text { entre fragmentos } \\
\text { na paisagem }\end{array}$ & $\begin{array}{l}\text { Literatura varia de } \\
30 \text { a } 460 \text { metros }\end{array}$ & $\begin{array}{l}\text { Consultar biólogos } \\
\text { locais para } \\
\text { informação } \\
\text { específica }\end{array}$ \\
\hline Plantas & $\begin{array}{l}\text { Consultar biólogos } \\
\text { locais para } \\
\text { informação } \\
\text { específica }\end{array}$ & $\begin{array}{l}\text { Literatura varia de } 2,0 \\
\text { a } 100,0 \text { hectares para } \\
\text { grupamentos de } \\
\text { árvores }\end{array}$ & $\begin{array}{l}\text { Mantém conexão } \\
\text { entre fragmentos } \\
\text { na paisagem }\end{array}$ & $\begin{array}{l}\text { Consultar biólogos } \\
\text { locais para } \\
\text { informação } \\
\text { específica }\end{array}$ & $\begin{array}{l}\text { Consultar biólogos } \\
\text { locais para } \\
\text { informação } \\
\text { específica }\end{array}$ \\
\hline
\end{tabular}




\subsubsection{BAIRROS ECOLÓGICOS}

Os bairros são as unidades básicas dos assentamentos humanos. Segundo os novos urbanistas, o bairro é o assentamento que tem limites e centro definido, sua escala é adequada ao pedestre e é diversificado quanto a tipologias de edifícios, pessoas e usos. A definição de bairro na era moderna é ilustrada pela unidade de bairro de Clarence Perry, desenvolvida em 1924 e mais tarde publicada no Plano Regional de Nova York e seus ambientes (FARR, 2006, p.42).

O modelo de Perry considera o bairro ideal com o tamanho de 64,75 hectares, com ruas principais em seu perímetro, comércio diversificado, escritórios, áreas cívicas e espaços livres públicos como parques conectados por um sistema viário e uma população grande suficiente para dar suporte a distâncias a pé de escola de ensino fundamental. O diagrama de bairro de Perry influenciou os novos urbanistas na década de 90 , funcionando como a unidade ideal para o planejamento e o faseamento de empreendimentos de grande escala o que nem sempre resultou em um bairro com escala suficiente para acomodar variedade. Victor Dover propõe o tamanho mínimo de bairro entre 16 hectares e 81 hectares, com a ocupação do centro de bairro entre 6 a 10\% do total da área.

O diagrama de bairro ilustrado na figura 5 mostra um bairro a partir de uma via importante de trânsito, o centro é ocupado por um terminal de alta intensidade como uma estação de BRT ou monotrilho, com infraestrutura verde, iluminação pública com controle de intensidade, uma estação de carro compartilhado por quadra, uso do solo diversificado e área para habitat e uma infraestrutura de corredores verdes que dão um caráter distinto para os limites do bairro.

A criação de destinos para o pedestre dentro de um bairro é determinante para que as pessoas andem para suprir as suas necessidades cotidianas. Destinos potenciais são: bancos, creches, centro comunitário, loja de conveniência, cabelereiro, academias, lavanderia, biblioteca, home office, dentista, farmácia, correios, restaurantes, escolas, supermercados entre outros. 
Figura 5:

Diagrama de Bairro Sustentável Douglas Farr, Leslie Oberholtzer e Christian Schaller FARR 2006, pagina 126

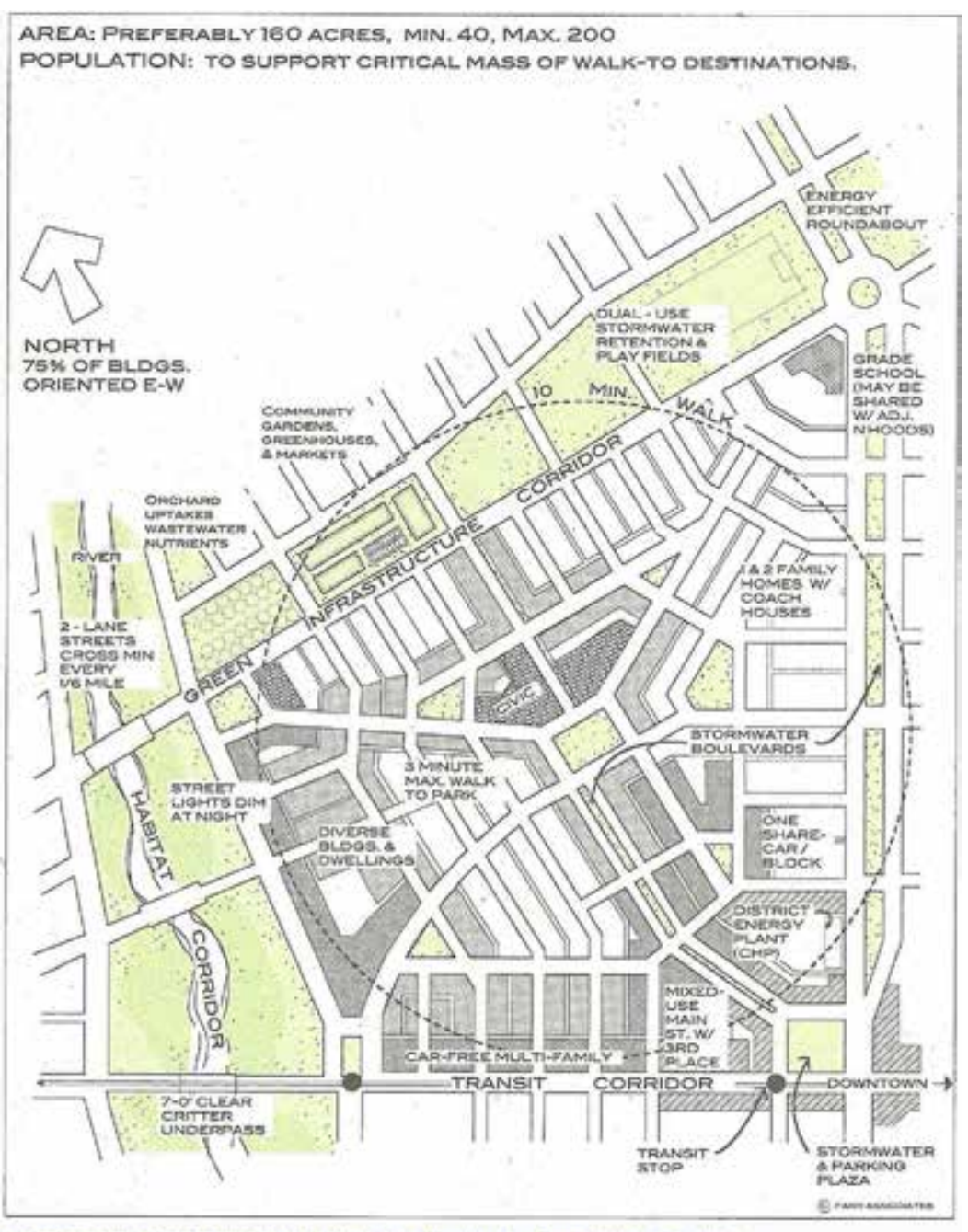

A Sustainable Neighborhood Unit fluilding Blocks of a Sustainable Comider)

\subsubsection{ESPAÇOS LIVRES, ELEMENTOS DA INFRAESTRUTURA VERDE}

Espaços livres qualificados como parques e praças propiciam dentro do bairro oportunidades para interação social além de oferecer acesso à natureza. A existência de um parque também valoriza o preço da terra no seu entorno, que gera retorno para a gestão pública e para empreendedores privados. Os parques desempenham importante função na filtração e gerenciamento das águas pluviais provenientes das ruas, um dos objetivos do Urbanismo Ecológico.

Segundo os padrões do Urbanismo Ecológico os parques ou outros espaços livres qualificados devem ser projetados dentro de um percurso de três minutos das áreas residenciais, a área mínima deve ser de $750 \mathrm{~m}^{2}$, o tamanho mínimo da média dos parques dentro de um 
bairro deve ser de $2.200 \mathrm{~m}^{2}$, os parques devem possuir ao menos duas ruas em seu perímetro e podem ou não ser cercados de acordo com demandas de segurança.

O Urbanismo Ecológico define cinco tipologias de espaços livres qualificados dentro de um bairro:

- Campos esportivos: projetados para espaços de lazer em grande escala, preferencialmente localizados nos limites do bairro devido ao seu tamanho e se tornar uma barreira para percursos de pedestres;

- Verde: espaço público médio disponível para uso flexível, cercado por edifícios cuja estrutura baseia-se em áreas gramadas e árvores;

- Square (praça): espaço público, menor que uma quadra, localizada no cruzamento de ruas importantes, cercada por edifícios e estruturada por caminhos pavimentados, áreas gramadas, árvores e edifícios cívicos dispostos formalmente;

- Plaza (praça): espaço público no cruzamento de ruas importantes, com edifícios públicos e cercada por edifícios de usos comerciais. Estruturada por pavimentação durável em estacionamentos sem marcação de vagas para proporcionar uso flexível e árvores com pouca manutenção;

- Jardins comunitários: Grupo de canteiros para cultivo em pequena escala, em condomínios residenciais, tetos verdes ou como na cidade de Seattle, em espaços públicos. A produção local de alimentos também estimula a reciclagem de resíduos orgânicos no uso em compostagem. (FARR, 2006)

\subsubsection{OS EDIFÍCIOS E A INFRAESTRUTURA DE ALTO DESEMPENHO}

Os projetos de edifícios e infraestrutura de alto desempenho são elementos importantes da estrutura básica do Urbanismo Ecológico. O consumo de energia e a emissão de dióxido de carbono pelos edifícios impactam na qualidade ambiental e técnicas para reduzi-las devem ser adotadas. 
A infraestrutura de alto desempenho engloba a rua e a calçada, infraestrutura pública enterrada como linhas de gás, eletricidade, galerias de águas pluviais e áreas verdes. Técnicas como jardins de chuva, biovaletas, seleção de espécies de baixa manutenção nos canteiros, arborização intensa minimizam o impacto ambiental da urbanização.

\subsubsection{ESTUDO DE CASO HIGH POINT SEATTLE}

High Point é um bairro próximo ao centro de Seattle, estado de Washington, Estados Unidos. O projeto foi resultado de uma parceria da Seattle Housing Authority, Departamento de Habitação da Prefeitura, com agências públicas e privadas, empreendedores e os residentes, a fim de transformar a área isolada de habitação de baixa renda em uma comunidade dentro de uma nova visão para habitação popular. O plano diretor foi desenvolvido pelo escritório Mithun Architects + Designers + Planners. Foram projetadas 1.600 unidades habitacionais distribuídas em vinte e cinco quadras para acomodar uma população aproximada de 4.000 residentes (FARR, 2006).

Para desencorajar o uso do automóvel, foram implantadas duas linhas de ônibus e há um estudo para se estender o monotrilho até a área. A área fica próxima a duas arteriais importantes, norte-sul e leste-oeste e possui um programa de compartilhamento de automóveis. As ruas internas se conectam com a malha de ruas existentes do entorno. A proximidade com o centro facilita o acesso aos polos de emprego.

Foram projetados dentro do bairro uma clínica, uma biblioteca pública e um centro comunitário. A Housing Authority, o Serviço de manutenção de áreas verdes públicas e a Associação de zeladoria oferecem postos de trabalho para residentes e uma escola de ensino fundamental existente foi incorporada ao projeto.

Cerca de 1/6 do total da área foi destinada a áreas verdes, convertidas em 21 parques públicos (FARR, 2006). A área também ocupa 10\% da bacia do riacho Longfellow, importante habitat para o salmão e para proteger a qualidade da água, ruas estreitas e jardins de chuvas foram projetados para tratar as águas pluviais superficiais. 
Figura 6:

Implantação geral do bairro High Point em Seattle extraída do livro Sustainable Urbanism, Urban Design with Nature. (FARR, 2006)

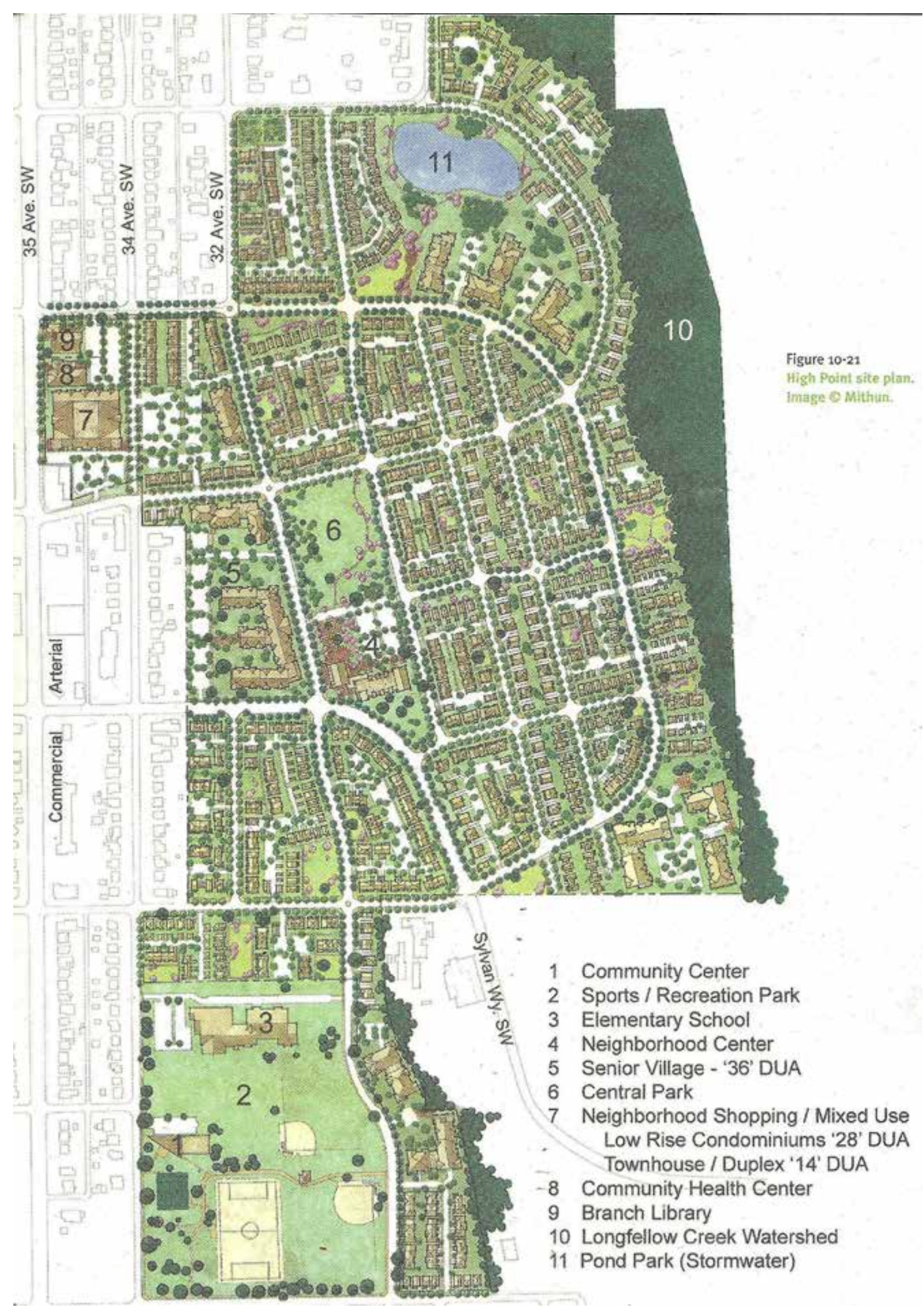

Capítulo 1 - Os conceitos de Crescimento Inteligente, Urbanismo Paisagístico e Urbanismo Ecológico 
A eficiência energética foi outra prioridade de projeto tanto na construção das casas como na infraestrutura pública. As calçadas são de pavimento com drenagem que conduzem a infiltração das águas diretamente no solo. A biodiversidade é outra tônica importante do projeto, com a manutenção de 150 árvores existentes e o plantio de novas espécies nativas. 0 projeto ainda inclui um jardim comunitário, objeto do capítulo 4 desta pesquisa, que fornece produtos para um mercado local e também para consumo próprio dos residentes participantes do programa.

O projeto habitacional previu um mix de rendas e tipologias variadas e a implantação de equipamentos públicos cujo objetivo é promover a interação social entre os residentes. As casas possuem varandas frontais para estimular a sociabilidade e a segurança com o movimento constante de pessoas na fachada para as ruas e o espaçamento entre postes de iluminação é de 8 metros e não segue o padrão da Prefeitura de 16 metros, o que melhorou a segurança. A empreiteira empregou cerca de 50 trabalhadores de baixa renda e os capacitou (FARR, 2006).

O plano foi bem sucedido na integração social com o projeto ecológico, dentro do orçamento do programa habitacional HOPE VI e a equipe de trabalho com o partido adotado mitigou os impactos de um empreendimento em larga escala, protegeu a bacia, reciclou materiais das construções demolidas, preservou mais de 150 árvores e hoje oferece aos seus residentes alta qualidade de vida.

\subsection{PLANEJAMENTO AMBIENTAL E O CASO DA CIDADE DE SÃO PAULO}

Em seu livro "Planejamento Ambiental para a Cidade Sustentável" (FRANCO, 2001, p.256), a autora Maria de Assunção Ribeiro Franco faz uma reflexão importante

(...) é preciso rever os conceitos e padrões dos planos diretores e códigos de obras, onde a questão ambiental até hoje, se entrou, foi por complemento e não por essência. Urge, portanto, que se faça uma revisão da legislação urbana sobre o prisma do Planejamento Ambiental, que contemple não só questões municipais, mas questões de âmbito regional integradas principalmente em três questões básicas: manejo das águas e 
áreas verdes, da circulação e transportes, o gerenciamento de resíduos, a questão da habitação e emprego, a questão da segurança e cidadania e a questão da educação ambiental.

A autora faz uma crítica aos planos elaborados para São Paulo, que possibilitaram a expansão, tanto da cidade como de sua região metropolitana, indefinida sobre o território sem considerar os limites finitos dos recursos naturais e propõe uma reformulação urbana da cidade e da megalópole a partir da criação de eixos verdes estruturais de uma Área de Proteção Ambiental (APA) Urbana Tietê - Pinheiros. Tal estratégia cria limites municipais e de Subprefeituras para o gerenciamento dos recursos com o objetivo de atingir a sustentabilidade ambiental urbana.

De fato, a paisagem, dentro desta proposta, apresenta-se como elemento estruturador e limitador da ocupação urbana, promovendo equilíbrio e uma melhoria significativa da qualidade de vida. A ideia central é guiar planos diretores e códigos de edificações a partir de princípios elaborados para a APA e suas faixas de proteção de preservação máxima, moderada e de transição.

Dentre os princípios destacam-se a regulamentação do uso e ocupação do solo urbano junto às várzeas e seu entorno, com diretrizes voltadas para o aumento da permeabilidade do solo e o incremento da arborização urbana do sistema viário e ao longo de cursos d'água. No âmbito local, são criados o Parque Linear Pinheiros e o Parque Linear Tietê, com largura mínima de 50 metros ao longo das marginais expressas. Tanto a APA quanto os Parques Lineares têm como suporte legal e teórico a Agenda 21, o Código Florestal Brasileiro, o Código das Águas, a lei estadual número 9.866/97 sobre a Nova Política de Mananciais e o Capítulo VI da Constituição Brasileira (FRANCO, 2001).

Nesta proposta, a cidade reconhece os rios como elementos estruturadores da ocupação urbana, baseada na sustentabilidade ambiental e estende-se por toda a área da Bacia do Alto Tietê. Busca-se promover uma mudança de visão, ética e valores sobre a relação do homem com a natureza, tendo como base princípios ecológicos e a transformação da cidade como “ecossistema humano" (FRANCO, 2001). 
Outros fatores importantes para o sucesso da APA são a educação, o turismo e o lazer como agentes catalisadores da geração de empregos, da redução das ocupações irregulares e da melhoria da qualidade de vida como um todo.

Sem dúvida, os princípios da APA configuram princípios do Urbanismo Ecológico em São Paulo e que embasam as diretrizes apresentadas no capítulo 8 para a urbanização do entorno da Arena Corinthians em Itaquera, a partir da estruturação de áreas verdes conectadas aos cursos d'água existentes em um cenário futuro de recuperação ambiental e despoluição. 


\section{CAPÍTULO 2 \\ O CONCEITO DE PAISAGEM}

2.1 PAISAGEM

2.20 SOLO

2.30 TEMPO 


\subsection{PAISAGEM}

Que impacto tem o conceito de paisagem no desenho da cidade?

Segundo Palmboom (2010), a paisagem do ponto de vista geográfico é uma parte da superfície da Terra na qual ela mostra características dinâmicas e não somente estéticas. A arquitetura paisagística trata a paisagem como uma entidade onde processos bióticos e abióticos se expressam e onde os processos de ocupação, urbanização e cultivo acontecem. A arquitetura paisagística guia e influencia estes processos, dando forma a eles a fim de solucionar demandas práticas e estéticas. Este conceito mais amplo da paisagem a aproxima em uma relação contemporânea com o urbanismo. Entender as características da paisagem significa entender a cidade contemporânea, e, desta maneira, melhor projetá-la.

A primeira delas é sua amplitude. A extensão da paisagem extrapola a cena retratada e limitada por uma moldura de um quadro. Compreender o todo é mais importante que a parte. Cada cena é dinâmica e influenciada pelas condições de seu contexto mais amplo, como a topografia, as questões climáticas, a fauna e a flora (PALMBOOM, 2010).

A segunda característica importante é a sua ambiguidade. O número de contrastes é infindável, sejam eles naturais ou culturais, ao mesmo tempo em que a paisagem se torna um lugar comum, expressão da arte de sobreviver no cultivo da terra, na vida selvagem ou pode se transformar em um cenário extraordinário. Isso se aplica não somente às paisagens naturais como desertos, oceanos, montanhas e florestas, mas também a paisagens culturais constituídas por pirâmides, os eixos monumentais de Versailles ou Washington, os arranhacéus de Manhattan etc. (PALMBOOM, 2010).

A terceira característica, segundo Fritz Palmboom, é que a paisagem é dinâmica e traz consigo os traços do tempo, sofre mudanças constantemente que deixam marcas que contam sua história, suas origens e seu desenvolvimento. Além disso, a paisagem é material, tangível e física e resulta da interação entre a terra, a água e os ventos.

Outra característica é que paisagens são específicas e fortemente ligadas ao lugar, ao seu contexto. Podem ser classificadas tipologicamente, como os seus ecossistemas, biomas e 
${ }^{1}$ “Planícies que inundadas ou sujeitas a inundações pelo mar ou rios, são protegidas por diques e dessecadas continuamente com o fim de torná-las utilizáveis na agricultura e/ou na habitação. Grande parte do território da Holanda é constituído de pôlderes" (FERREIRA, Aurélio Buarque de Holanda; 1988).

2 G. C. Argan, "The City as a Work of Art" em Andreu Arriola, Carme Fiol. Barcelona, Spaces and Sculptures (1982-1986), Barcelona 1987, páginas 29-33: "A realidade histórica de uma cidade não é catarse: é um drama". não são transferíveis. Por último, as paisagens são criadas parcialmente pela ação antrópica, pois mesmo que sejam totalmente projetadas como, por exemplo, a paisagem holandesa dos pôlderes ${ }^{1}$, depende de relações dinâmicas com o meio natural.

Segundo Palmboom (2010), todas estas características são aplicáveis à condição atual da cidade. A cidade também é um fenômeno da paisagem. Não pode mais ser concebida como um objeto arquitetônico destacado da paisagem que a compreende. Na essência, é a paisagem urbanizada, extensa, fluida, conjunto de diversas camadas marcadas pelo tempo, pelo pragmatismo da sobrevivência com flashes ocasionais de aspirações estéticas. Cada intervenção deve considerar suas camadas complexas, conflitos e o uso de seu potencial e combinação inesperada de contrastes.

Sob este ponto de vista, a paisagem não pode ser vista mais de forma romântica, idílica e antagônica à cidade. A paisagem é a arena onde se confrontam forças naturais e culturais de todas as origens. Os arquitetos paisagistas têm o desafio de mediar estes confrontos e transformá-los em experiências visuais. Não é a reconciliação ou a catarse que comanda a atenção sobre a situação de enfrentamento e sim o drama de sua realidade histórica ${ }^{2}$.

\subsection{SOLO}

A paisagem começa com a terra, o solo. O nível térreo nas cidades e nas paisagens não é superficial e bidimensional. Possui profundidade e dentro dela uma diversidade de materiais, definida por suas camadas geológicas. Está sujeita à dinâmica natural em que a terra, a água e os ventos afetam uns ao outros. É tridimensional mesmo em uma região plana de um delta (PALMBOOM, 2010).

Palmboom cita a paisagem holandesa como uma paisagem típica de transições relativamente nova e extremamente dinâmica. É o resultado de uma interação complexa entre homem e natureza: o processo de construção dos diques que se iniciou na Idade Média e persiste até os dias de hoje. O equilíbrio da relação entre terra e água se expressa na fundação de uma estrutura espacial estável. 
O substrato instável demanda o preparo cuidadoso do solo antes da construção de qualquer edificação, sendo o sistema de drenagem, contenções e canais adaptados. Adiciona-se areia para aumentar a capacidade de suporte de carga. Ruas e rodovias devem ser construídas completas com infraestrutura e bombas devem ser instaladas. Isso faz parte das necessidades técnicas e físicas do desenho urbano, separadas dos conceitos e ideologias de projeto. Requer planejamento antes da arquitetura.

Preparar o solo é parte de um processo complexo que precede ao edifício. Dar forma ao solo através de uma curva em um caminho, da colocação de degraus traz vida à paisagem e a consciência do chão no qual se fica em pé, dá ao edifício um contexto, um lugar onde pousar e pertencer (PALMBOOM, 2010).

\subsection{TEMPO}

A arquitetura paisagística se expressa em um processo de longa duração. As árvores e outras espécies vegetais têm seu ciclo de crescimento, florescimento e declínio por muitas décadas. Um parque, uma nova paisagem só atinge plena maturidade após décadas de seu plantio.

O urbanismo constrói-se sobre os recursos e processos naturais, transformando-os de forma a fazer com que a paisagem atenda novas funções urbanas. Apropria-se de terras antes ocupadas pelo tempo mais lento da natureza e da agricultura e dá ao lugar o ritmo mais acelerado da vida urbana (PALMBOOM, 2010). 


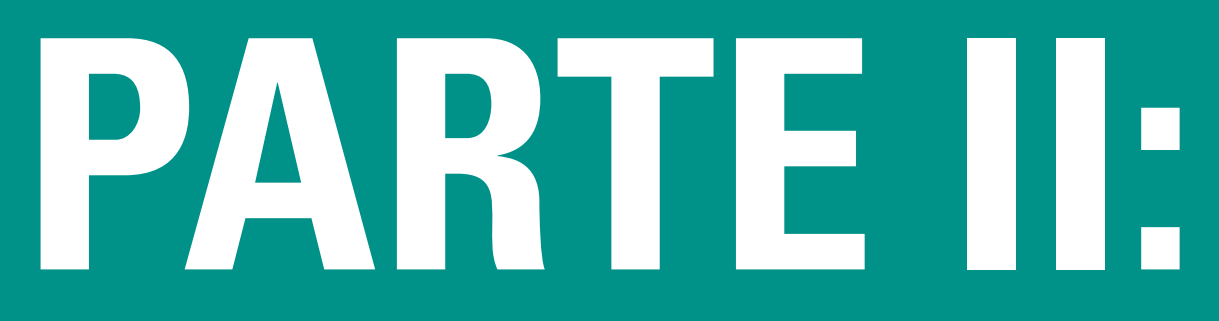

A INFRAESTRUTURA VERDE NO PROJETO DOS BAIRROS 


\section{CAPÍTULO 3 \\ O CONCEITO DA INFRAESTRUTURA VERDE E 0 NOVO PARADIGMA PARA O DESENHO DOS BAIRROS}

3.1 A REDE DA INFRAESTRUTURA VERDE

3.2 A ESCALA DA INFRAESTRUTURA VERDE

3.3 OS PRINCÍPIOS DA INFRAESTRUTURA VERDE

3.4 AS FLORESTAS URBANAS

3.5 O PROJETO DA REDE DA INFRAESTRUTURA VERDE 3.5.1 ÂNCORAS

3.5.2 CONEXÕES LINKS

3.6 A IMPLANTAÇÃO DA INFRAESTRUTURA VERDE 
O termo infraestrutura verde possui significados distintos de acordo com o contexto em que é usado. Segundo os autores Mark Benedict e Edward McMahon, do livro Green Infrastruture Linking Landscapes and Communitites, o conceito de infraestrutura verde pode se referir às árvores que propiciam benefícios ecológicos no meio urbano ou às estruturas de engenharia ligadas ao sistema de drenagem de águas pluviais, conhecidos como jardins de chuva.

Para esta pesquisa, adota-se a definição dos autores de que a infraestrutura verde é uma rede constituída de áreas naturais e outras áreas livres que preservam as funções do ecossistema natural, fornece ar e água livres de poluição e provê uma gama de benefícios para as pessoas e a vida selvagem. Abriga um sistema de apoio à vida natural não só na área ambiental, mas também na área econômica e da saúde.

Pela definição do dicionário Webster, infraestrutura é a estrutura de fundação da qual depende o crescimento e a continuidade de uma comunidade ou estado. Dentro desta definição, as áreas verdes da infraestrutura verde passam de amenidades para necessidade e precisam ser gerenciadas, protegidas e recuperadas.

A infraestrutura verde como substantivo refere-se a uma rede de espaços verdes interconectados, incluindo áreas naturais, propriedades públicas e privadas com áreas verdes conservadas, terras agriculturáveis com valores de conservação e outros espaços livres protegidos que são planejados e gerenciados por seus valores ecológicos e pelos benefícios que conferem às pessoas. Como adjetivo, a infraestrutura verde descreve o processo que promove uma aproximação estratégica e sistemática à conservação no âmbito nacional, estadual, regional e local, de forma a produzir um planejamento de uso e ocupação do solo e práticas positivas para a natureza e para as pessoas (BENEDICT, McMAHON, 2006, p. 03).

Como conceito ou processo, a infraestrutura verde traz benefícios. Como conceito, o planejamento e o gerenciamento da rede de sua infraestrutura podem resultar em um sistema estruturado de espaços livres com a definição de âncoras e conexões que promovem preservação associada a áreas verdes de uso recreativo, conectam recursos naturais presentes em áreas verdes preservadas e futuramente preservadas e preenchem os vazios. Como processo, auxilia na identificação de áreas estratégicas a serem protegidas. A infraestrutura verde tem 
a capacidade de guiar o crescimento e o desenvolvimento das ocupações urbanas, além de apoiar decisões com relação à preservação, a fim de acomodar o crescimento populacional e ao mesmo tempo proteger os recursos naturais. Desta forma, adiciona valores aos resultados, dando suporte a ambientalistas e empreendedores.

Menos de $10 \%$ das terras dos Estados Unidos permanecem no seu estado natural intocado, selvagem, dos quais apenas $4 \%$ foram destinados para reserva natural. Nos últimos 50 anos, a ocupação urbana nos Estados Unidos quadruplicou. Entre 1982 e 2001, uma área de 13,775 milhões de hectares, do tamanho do Estado de Illinois foi convertida para usos urbanos, dos quais $46 \%$ eram florestas, $20 \%$ terras agriculturáveis e $16 \%$ eram pastos que foram transformados em habitações, comércios, escritórios e estacionamentos (BENEDICT; McMAHON, 2006).

De 1982 a 1997, uma média de 275.000 hectares de florestas dentro de propriedades privadas foi desmatada e ocupada. Entretanto, nos últimos cinco anos deste período a média subiu para 404.685 hectares, crescendo de forma exponencial em todo território norte americano. Em 2006, cerca de 808.000 hectares de áreas agriculturáveis e 202.000 hectares de florestas privadas deram lugar a empreendimentos. A ocupação de terras não corresponde ao aumento populacional nos Estados Unidos, entre 1982 e 1997, enquanto a área urbanizada cresceu 46\%, a população cresceu apenas 17\% (BENEDICT; McMAHON; 2006 p. 5 e 6).

Atualmente, cidades como Detroit estão em processo de esvaziamento e a questão é o que fazer com os terrenos subutilizados. Reflorestá-los seria uma estratégia interessante, de forma a recuperar sua função ecológica, em substituição ao uso urbano falido. A diversidade, o número de espécies e seus indivíduos poderiam aos poucos retomar o espaço perdido para urbanização.

As áreas alagadas, por exemplo, quando não aterradas têm a função de controlar enchentes, reter sedimentos e filtrar poluentes. Atualmente mais de $50 \%$ das superfícies urbanizadas são impermeáveis, o que aumenta o volume de águas pluviais superficiais e o risco de enchentes e prejudica a habilidade da natureza em filtrar a água e baixar a temperatura do ar. A urbanização ainda, através da prática de terraplenagem e limpeza de terrenos adiciona químicos, sedimentos e outras substâncias que degradam a qualidade da água. Um artigo 
publicado na revista Science sobre um estudo de 2002 conclui que a destruição de habitats custa ao mundo o equivalente a 250 bilhões de dólares por ano, enquanto sua conservação poderia gerar um benefício de mais de 4.4 trilhões por ano (BENEDICT; McMAHON, 2006, p. 09).

A fragmentação da natureza em áreas verdes menores afeta a paisagem de forma crítica, incluindo a disponibilidade de recursos, a degradação ambiental, recreativa e a qualidade visual, além do prejuízo à sobrevivência das espécies vegetais e animais. A distância crescente entre os fragmentos faz com que haja o isolamento destas espécies, menor diversidade e menor possibilidade de sobrevivência.

Cerca de 95\% das espécies listadas como em extinção pelo governo federal americano são ameaçadas pela perda de habitat, fragmentação e outras formas de alteração. Na Califórnia, o aumento do subúrbio é a principal causa de diminuição de áreas naturais e fragmentação. A área metropolitana, por sua vez, concentra $29 \%$ das espécies raras ou em extinção, onde há uma relação intrínseca entre a fauna e flora locais e os assentamentos humanos (BENEDICT; McMAHON; 2006 p. 9).

Os efeitos decorrentes da urbanização sobre os recursos naturais ultrapassam limites administrativos, por isso a necessidade do planejamento ambiental ser regional, embora não haja poder administrativo nesta escala. Em São Paulo há uma possibilidade de criação de tal poder com o recém-criado Parlamento Metropolitano, que reúne os Presidentes das 39 Câmaras de Vereadores de sua região metropolitana.

\subsection{A REDE DA INFRAESTRUTURA VERDE}

A infraestrutura verde engloba uma variedade de ecossistemas naturais e ecossistemas restaurados, assim como os elementos da paisagem que os compõem, incluindo áreas preservadas como alagados, florestas, cursos d'água, áreas de conservação privadas e públicas como parques nacionais e estaduais, reservas ecológicas, corredores de fauna, florestas em propriedades privadas, fazendas e outras áreas verdes protegidas como parques e praças. 
Segundo Benedict e McMahon (2006), a infraestrutura verde conecta ecossistemas e paisagens através de um sistema de âncoras (hubs), conexões (links) e sítios (sites).

As âncoras abrigam vegetação nativa e grupos de animais, assim como são os locais de origem e destino das migrações de fauna, pessoas e processos ecológicos dinâmicos dentro do sistema. Eles podem ter dimensões e formas diversas, incluindo refúgios ecológicos, parques estaduais, áreas verdes privadas, parques regionais e de bairros significativos.

Os links, como o próprio nome indica, são as conexões do sistema, fundamentais para a manutenção vital dos processos ecológicos e das condições de saúde e biodiversidade da vida selvagem. As conexões de paisagem são links longos e largos e ligam parques, áreas de preservação, ao mesmo tempo em que funcionam como corredores ecológicos para desenvolvimento das espécies. Tais ligações também oferecem espaços para proteção de sítios históricos, culturais e oportunidades para uso recreativo. Exemplos de conexões lineares, os cursos d'água têm função biológica importante e, assim como cinturões verdes, criam limites para os assentamentos e também provêm espaços para uso recreativo e contemplativo.

Os sítios têm dimensões menores que as âncoras, mas possuem função local importante tanto ecológica como de habitat e social, como locais para uso contemplativo e recreativo das comunidades do entorno.

As âncoras, as conexões e os sítios variam de dimensões, função e propriedade, seja pública ou privada. Apesar de não serem “verdes", rios e pequenos cursos d'água são elementos críticos do sistema de infraestrutura verde, assim como desertos e montanhas cobertas de neve, importantes como âncoras e corredores ecológicos (BENEDICT; McMAHON, 2006).

O objetivo da infraestrutura verde é proteger os recursos naturais e a biodiversidade, embora inclua uma variedade de elementos que não estão diretamente ligados a este objetivo. Um exemplo disso são as faixas verdes do sistema viário, trilhas de lazer, sítios de importância histórica, cultural e arqueológica que valorizam os bairros e tornam-se valores importantes da comunidade. Áreas verdes produtivas como terras agriculturáveis, áreas de reflorestamento, possuem função econômica e também fazem parte da rede de infraestrutura verde e do Urbanismo Ecológico, que tem na paisagem o seu principal alicerce. 


\subsection{A ESCALA DA INFRAESTRUTURA VERDE}

A infraestrutura verde pode ser aplicada em qualquer escala, da área verde do bairro aos corredores ecológicos e conectores de maciços florestais. $\mathrm{O}$ ponto de partida para sua implantação está na procura por oportunidades, seja na conservação de fragmentos de valor ecológico que podem servir de âncoras e conexões, seja em áreas potenciais então ocupadas com outros usos (BENEDICT; McMAHON; 2006, p. 14).

As estratégias de infraestrutura verde variam de acordo com o seu contexto. No caso de áreas rurais, identificar áreas de interesse ecológico e mapeá-las é o primeiro passo para protegê-las. Através do mapeamento, pode-se planejar a ocupação de forma a concentrar a ação antrópica nas áreas mais apropriadas, tanto para a agricultura como para a implantação de áreas de recreação e lazer, sendo a escolha condicionada pela fauna e flora presentes, cursos d'água, clima e pela topografia. Nos centros urbanos, da mesma forma, a identificação de cursos d'água e a proteção de suas margens e vegetação ripária, arborização contínua como conexão de fragmentos florestais maiores, criação de parques e praças, incentivo ao plantio nos quintais e a implantação de jardins comunitários e agricultura urbana nos bairros, fazem parte de estratégias importantes da infraestrutura verde.

Embora o termo seja recente, o conceito de infraestrutura verde não é novo e tem origem em duas iniciativas fundamentais: proteger e conectar áreas verdes para o benefício das pessoas como recreação, saúde e através da implantação do Urbanismo Ecológico e preservar e conectar áreas naturais para o benefício da biodiversidade com a proteção de espécies nativas, animais, processos naturais e ecossistemas.

O movimento da Infraestrutura Verde tem suas raízes no estudo da terra e da relação do homem com a natureza, que teve início há mais de 150 anos. Muitas disciplinas, ao longo destes anos, contribuíram com teorias, ideias e pesquisas para o aumento do campo, principalmente os que guiaram a criação nos Estados Unidos dos parques nacionais e estaduais como estratégia de proteção da vida selvagem como florestas, rios e alagados. No seu desenvolvimento, a Infraestrutura Verde tornou-se interdisciplinar e foi incorporada pelas disciplinas de planejamento urbano, arquitetura paisagística, gestão, engenharia e desenho ambiental, com foco no impacto do desenvolvimento urbano sobre a natureza e seus processos. 
Tabela 3.1 -

O Surgimento da infraestrutura verde. (BENEDICT; McMAHON; 2006, p. 25, tradução nossa).
Cria uma metodologia científica para se determinar o melhor uso da terra a fim de servir de suporte para os processos naturais existentes na paisagem e a infraestrutura de suporte às pessoas que nela habitam (BENEDICT; McMAHON; 2006 p. 23).

\begin{tabular}{|c|c|c|}
\hline Período & Marcos importantes & Conceitos chave \\
\hline $\begin{array}{l}\text { Os anos de formação: } \\
1850-1900\end{array}$ & $\begin{array}{l}\text { - Henry DavidThoreau escreve sobre a } \\
\text { “importância de se preservar algumas porções } \\
\text { da natureza únicas” Frederic Law Olmsted cria } \\
\text { o conceito de sistemas conectados de parques } \\
\text { e vias parque } \\
\text {-A primeira rede de espaços abertos é finalizada } \\
\text { em Minneapolis - Sistema de Parques St. Paul } \\
\text {-A ideia de cinturão verde é introduzida na } \\
\text { Inglaterra para prevenir a conurbação } \\
\text { - Man and Nature de George Perkins Marsh é } \\
\text { publicado }\end{array}$ & $\begin{array}{l}\text { - O caráter intrínseco da terra deve guiar } \\
\text { seu uso }\end{array}$ \\
\hline $\begin{array}{l}\text { Experimentação e Evolução: } \\
1900-1920\end{array}$ & $\begin{array}{l}\text { - A via parque do Rio Bronx torna-se a primeira } \\
\text { via parque projetada para veículos } \\
\text {-Warren Manning usa a técnica para analisar } \\
\text { a informação natural e cultural sobre um } \\
\text { terreno } \\
\text { - O Presidente Theodore Roosevelt, por gostar } \\
\text { da vida ao ar livre leva a questão da } \\
\text { conservação para a agenda nacional } \\
\text { - O Parque NacionalYellowstone torna-se } \\
\text { referência para o sistema de parques naturais } \\
\text { - O conceito de cinturão verde é incluído no } \\
\text { plano de } 1920 \text { para Radburn, New Jersey }\end{array}$ & $\begin{array}{l}\text { - Experimentação com metodologias } \\
\text { em planejamento em larga escala } \\
\text { - Conservação de lugares naturais para } \\
\text { futuras gerações }\end{array}$ \\
\hline $\begin{array}{l}\text { Desenho Ambiental: } \\
\text { 1930-1950 }\end{array}$ & $\begin{array}{l}\text { - Biólogo/ecologista Victor Shelford pede pela } \\
\text { preservação de áreas naturais e zonas de } \\
\text { amortecimento } \\
\text { - Como parte do New Deal americano, uma } \\
\text { série de comunidades com cinturões verdes } \\
\text { são projetadas com ênfase na inclusão de } \\
\text { áreas verdes no desenho urbano e no } \\
\text { amortecimento de usos de solos adjacentes } \\
\text { - Benton MacKaye cria a disciplina de } \\
\text { planejamento regional e promove a trilha dos } \\
\text { apaches com um cinturão de áreas abertas } \\
\text { para proteger o Oeste dos assentamentos em } \\
\text { expansão } \\
\text { - Aldo Leopold introduz o conceito de ética da } \\
\text { terra focando nos princípios fundamentais da } \\
\text { ecologia }\end{array}$ & $\begin{array}{l}\text { - Conexão entre ecologia e projeto } \\
\text { - Princípios éticos de uso do solo } \\
\text { - Preservação da natureza no seu estado } \\
\text { selvagem }\end{array}$ \\
\hline
\end{tabular}

continua. 


\begin{tabular}{|c|c|c|}
\hline Período & Marcos importantes & Conceitos chave \\
\hline $\begin{array}{l}\text { A década da ecologia: } \\
1960\end{array}$ & $\begin{array}{l}\text { - O planejador urbano e arquiteto paisagista } \\
\text { lan McHarg advoga que a ecologia deve servir } \\
\text { de base para o projeto } \\
\text { - Philip Lewis cria um método de análise da } \\
\text { paisagem que foca nos corredores ecológicos } \\
\text { e suas características como vegetação e } \\
\text { estética do cenário } \\
\text {-Willian H. Whyte introduz o termo e conceito } \\
\text { de greenway ,"corredor verde". } \\
\text {-A ecologia da paisagem emerge com o foco } \\
\text { nas interaçöes entre as comunidades } \\
\text { biológicas e o meio ambiente físico } \\
\text {-A biogeografia de ilhas explora a relação entre } \\
\text { espécies e paisagem } \\
\text { - O Congresso americano aprova a lei da vida } \\
\text { selvagem The Wilderness Act } \\
\text { - Rachel Carson publica Silent Spring, com } \\
\text { atenção ao impacto do homem sobre a } \\
\text { natureza }\end{array}$ & $\begin{array}{l}\text { - Análise da paisagem e sua } \\
\text { adequabilidade } \\
\text { - Planejamento do uso do solo através } \\
\text { de processo científico } \\
\text { - Proteção de áreas chave da vida } \\
\text { selvagem }\end{array}$ \\
\hline $\begin{array}{l}\text { Refinamentos dos conceitos chave: } \\
\text { 1970-1980 }\end{array}$ & $\begin{array}{l}\text { - O Programa do Homem e da Biosfera promove } \\
\text { o conceito de áreas chave cercadas por zonas } \\
\text { de uso do solo compativeis } \\
\text { - A Biologia da Conservação é introduzida como } \\
\text { disciplina que aplica os princípios da ecologia } \\
\text { à manutenção da diversidade biológica } \\
\text { - O Fundo para Conservação estabelece o } \\
\text { Programa Americano de Corredores Verdes } \\
\text { que promove corredores verdes em todo o } \\
\text { país } \\
\text { - RichardT.T Foreman lidera nos Estados Unidos } \\
\text { em ecologia e ética da paisagem } \\
\text { - Larry Harris e Reed Noss criam e promovem } \\
\text { o projeto e a proteção de sistemas de reservas } \\
\text { regionais } \\
\text { - O Geoprocessamento é introduzido como } \\
\text { ferramenta para o planejamento regional } \\
\text { - A Comissão das Nações Unidas para o Meio } \\
\text { Ambiente e Desenvolvimento conclui que o } \\
\text { desenvolvimento sustentável requer que o } \\
\text { crescimento populacional esteja em harmonia } \\
\text { com o potencial em constante transformação } \\
\text { do ecossistema }\end{array}$ & $\begin{array}{l}\text { - Ciência e processo são necessários } \\
\text { para guiar o complexo planejamento } \\
\text { do uso do solo que considera as } \\
\text { características da ecologia } \\
\text { - Preservar as áreas naturais isoladas } \\
\text { não é suficiente para proteger a } \\
\text { biodiversidade e os processos } \\
\text { ecossistêmicos } \\
\text { - A conexão entre as áreas naturais são } \\
\text { necessárias }\end{array}$ \\
\hline
\end{tabular}




\begin{tabular}{|c|c|c|}
\hline Período & Marcos importantes & Conceitos chave \\
\hline $\begin{array}{l}\text { A crescente ênfase nas conexões: } \\
1990 \text { e além }\end{array}$ & $\begin{array}{l}\text { - Os Estados de Maryland e Florida iniciam } \\
\text { esforços de planejamento para criar sistemas } \\
\text { estaduais de corredores verdes e espaços } \\
\text { verdes } \\
\text { - O Projeto das Terras Selvagens, The Wildlands } \\
\text { Project, é criado para estabelecer o sistema } \\
\text { norte americano de terras selvagens } \\
\text { interconectadas. } \\
\text { - O Presidente da Comissão de Desenvolvimento } \\
\text { Sustentável identifica a Infraestrutura Verde } \\
\text { como uma das cinco áreas estratégicas que } \\
\text { fornece um olhar completo para o } \\
\text { desenvolvimento sustentável de uma } \\
\text { comunidade } \\
\text { - Cresce o interesse na Infraestrutura Verde } \\
\text { como ferramenta para guiar o desenvolvimento } \\
\text { e a conservação de terras }\end{array}$ & $\begin{array}{l}\text { - Foco na escala da paisagem } \\
\text { - Entendimento dos padrões e processos } \\
\text { da paisagem } \\
\text { - O planejamento da Infraestrutura Verde } \\
\text { requer a identificação e a conexão de } \\
\text { áreas de conservação prioritárias } \\
\text { - Processos de decisão baseados em } \\
\text { participação e consenso }\end{array}$ \\
\hline
\end{tabular}

A Infraestrutura Verde deve ser projetada para guiar a ocupação urbana e estabelecer as condições para o crescimento das cidades, através da identificação de terrenos ecologicamente significativos e a seleção de áreas adequadas ao desenvolvimento urbano. Desta maneira, ela se transforma em uma importante ferramenta de conservação e estratégia chave para se atingir o equilíbrio ambiental.

Os primeiros projetos em larga escala implantados nos Estados Unidos surgiram em 1990, com o planejamento de corredores verdes em todo o Estado de Maryland, com levantamento do bioma e a criação de mapas de Infraestrutura Verde. Os projetos tiveram origens distintas: como elemento integrante do movimento Crescimento Inteligente (Smart Growth), como resultado da mobilização das comunidades por mais áreas verdes para recreação e função ecológica nos bairros, ou com o foco na conservação de recursos naturais. Todos reconheceram o valor da paisagem como base para o uso do solo. 


\subsection{OS PRINCÍPIOS DA INFRAESTRUTURA VERDE}

Os princípios da Infraestrutura Verde promovem o desenvolvimento sustentável com o foco na conservação dos recursos naturais para benefício das pessoas e da vida selvagem. São eles:

\section{1. "Conexão é chave."}

A conexão descrita por Benedict e McMahon constitui-se na conexão das áreas naturais com outros espaços livres e entre as pessoas e os programas. Com este conceito, reforçase a necessidade de se proteger sistemas de espaços livres contínuos, além de áreas isoladas de valor ecológico significativo. Quanto às pessoas e aos programas, pesquisas, estudos focados na identificação e preservação de ecossistemas, organizações captadoras de fundos, auxiliam na criação do suporte necessário para sustentar a Infraestrutura Verde.

\section{2. "O contexto importa."}

O entendimento do contexto físico e biológico, onde os ecossistemas se encontram, é importante para entender as dinâmicas e transformações de paisagens e ecossistemas naturais. Alterações em uso do solo em áreas adjacentes às áreas preservadas podem impactar seus recursos; são os chamados efeitos de borda. É importante que o planejamento das áreas de conservação ultrapasse os seus limites para uma leitura mais detalhada da paisagem em escala regional.

\section{3. "A Infraestrutura Verde deve ser baseada na ciência e no planejamento do uso do solo."}

A Infraestrutura Verde não é um conceito novo e recebeu contribuições de diversas áreas do conhecimento como ecologia da paisagem, biologia, planejamento regional e urbano, arquitetura paisagística, geografia e engenharia civil. A implementação de estratégias decorre deste entendimento multidisciplinar e resulta no equilíbrio entre considerações ecológicas, culturais, sociais nos processos de decisão. 


\section{4. "Pode e deve ser utilizada como parâmetro para conservação e desenvolvimento."}

A Infraestrutura Verde oferece ferramentas para o planejamento do crescimento dos centros urbanos a fim de preservar sistemas de áreas verdes suficientes para acomodar funções ecológicas necessárias para criação de comunidades saudáveis. O mapeamento dos sistemas é fundamental para guiar novos empreendimentos e dimensioná-los de acordo com a capacidade do suporte físico.

\section{5. "Deve ser projetada e protegida antes da ocupação do solo."}

Proteger áreas ainda conservadas é mais econômico do que restaurar ecossistemas degradados, portanto, a Infraestrutura Verde, como ferramenta de planejamento é importante. Em 1940, o Condado de Montgomery, no Estado de Maryland, iniciou a compra de terras ao longo dos principais cursos d'água para preservação destas áreas antes da instalação de empreendimentos e formou com isso um sistema de parques ao longo dos vales. Quem visita a região percebe o valor da preservação destas áreas, na medida em que hoje elas fazem parte de um circuito de trilhas e ciclovias utilizado no cotidiano e nos deslocamentos da casa ao trabalho.

6. "A Infraestrutura Verde é um investimento público importante e deve ser financiado antecipadamente."

Assim como o poder público investe recursos na chamada Infraestrutura Cinza, constituída da rede de transportes, água, esgoto, eletricidade, telecomunicações e outros sistemas, devem-se criar mecanismos de arrecadação e direcionamento de fundos para investimento na Infraestrutura Verde, vital para a saúde dos centros urbanos e as comunidades.

\section{7. "Promove benefícios para as pessoas e para a natureza."}

A preservação de sistemas de áreas verdes propicia benefícios à saúde, protege a vida selvagem e economiza recursos públicos no investimento da Infraestrutura Cinza, pois 
funciona como prevenção a inundações, deslizamentos de terra e outros desastres naturais. O mapeamento das áreas de risco é uma das estratégias utilizadas antes da ocupação.

8. “Respeita as necessidades dos proprietários e outros stakeholders."

As áreas incorporadas nos sistemas de áreas verdes não são todas públicas. É importante a inclusão dos proprietários privados na discussão desde o início na elaboração das propostas de implantação de Infraestrutura Verde, para que as áreas a serem preservadas dentro de suas propriedades façam parte do sistema e que o valor da preservação destas áreas seja comprovado.

9. "Requer conexões com atividades dentro e fora das comunidades."

Projetar a Infraestrutura Verde junto com o Crescimento Inteligente (Smart Growth) auxilia governos e comunidades no planejamento de ocupações de áreas de forma a equilibrar interesses econômicos, ambientais, sociais e culturais.

\section{0. "Requer um compromisso de longo prazo."}

O planejamento da Infraestrutura Verde e o projeto do sistema de áreas verdes são considerados processos dinâmicos, pois dependem da forma como a ocupação urbana evolui. O compromisso de longo prazo assegura a manutenção de estratégias independentemente de mudanças políticas, de gestão ao longo do tempo (BENEDICT; McMAHON; 2006 p. 37). 
Os dados deste parágrafo foram extraídos de David Nowak, líder de projeto do U.S. Forest Service's Urban Forest Ecosystem Research Unit, como citado em Earth Talk: Questions and Answers about Our Environment, "As árvores urbanas realmente ajudam a reduzir a poluição e limpar o ar?" de John Alderman, 22 de Agosto de 2004. Nota extraída do livro Green Infrastrucure Linking Landscape and Communities de Mark A. Benedict e EdwardT. McMahon. P. 82, 2006.

“Executive Directions", CaseyTrees News, 3 de Junho de 2004. Nota extraída do livro Green Infrastrucure Linking Landscape and Communities de Mark A. Benedict e EdwardT. McMahon. P. 82, 2006.

\subsection{AS FLORESTAS URBANAS}

Frederic Law OsImsted chamava as árvores em meio urbano de "pulmões da cidade". Em Nova York, a cobertura de árvores ocupa 17 por cento da área da cidade com um total de cinco milhões de indivíduos que ajudam a remover toxinas do ar e economizar 10 milhões de dólares por ano em custos para mitigação da poluição'.

As árvores também baixam a temperatura das cidades. Grandes coberturas vegetais podem reduzir a temperatura da superfície entre 9 e 13 graus $^{2}$. Temperaturas mais baixas podem ser um importante fator para diminuir a produção de gases tóxicos como o ozônio e consequentemente mitigar doenças respiratórias como a asma. Além disso, as árvores servem de habitat para pássaros, e uma série de animais que trazem vida aos bairros.

Estudos revelam que para ser ambientalmente saudável, a cobertura por árvores de uma área não deveria ser menor do que $40 \%$, um número praticamente impossível para muitas áreas urbanas. Desde 1973, por exemplo, a região metropolitana de Atlanta perdeu cerca de 25\% de cobertura de árvores. Entre 1973 e 1997, Washington, D.C perdeu cerca de 64\%. Estes números se repetem onde a expansão da periferia ocorre (BENEDICT; McMAHON; 2006 p. 69).

\section{Benefícios da floresta urbana}

Pesquisas mostram que as árvores em cidades saudáveis:

- Criam um ar mais limpo, saudável;

- Baixam temperaturas de estacionamentos e carros estacionados;

- Mitigam o impacto da formação de ilhas de calor;

- Provêm sombra para casas e edifícios, resfriando-os e tornando-os energeticamente mais eficientes;

- Bloqueiam os ventos no Inverno;

- Retêm água da chuva em suas folhas e galhos, reduzindo o impacto das águas pluviais de superfície;

- Criam valores mais altos de mercado imobiliário;

- Criam nos bairros o senso de lugar; 
- Atraem mais compradores e investimentos aos distritos de negócios;

- Atraem novos negócios, proprietários e turismo;

- Reduzem violência doméstica e crime;

- Melhoram o desempenho de crianças na escola;

- Diminuem o período de permanência em hospitais e a necessidade de medicamentos;

- Reduzem a exposição à danosa radiação solar;

- Oferecem experiências regenerativas que melhoram sintomas de fadiga mental e estresse.

\subsection{O PROJETO DA REDE DE INFRAESTRUTURA VERDE}

O primeiro passo para se projetar a Infraestrutura Verde é estabelecer objetivos antes de desenhá-la sobre o território. O seu processo de construção varia de comunidade para comunidade, depende do nível de conservação, dos planos para o uso do solo, das características ecológicas e geográficas da paisagem e das prioridades.

Em Saving Nature's Legacy, Reed Noss e Allen Cooperrider basearam seus resultados sobre o projeto de reservas em cinco conceitos de projeto, descritos como estratégias de conservação, sendo o sexto conceito referente às espécies mais sensíveis à presença de impactos humanos. Descobriram que espécies bem distribuídas ao longo de suas áreas nativas de grande extensão eram menos suscetíveis à extinção do que espécies contidas em pequenas porções do território, grandes blocos de habitat contendo grandes populações de uma determinada espécie são superiores a pequenos blocos de habitat contendo pequenas populações, blocos de habitat próximos e juntos são melhores do que separados, habitat em blocos contínuos são melhores do que blocos fragmentados, blocos interconectados são melhores do que isolados e ainda descrevem que nem sempre animais e humanos devem estar juntos, sendo assim, alguns blocos de habitat não devem ter acesso.

Pensar na conexão da rede é importante, mas ela não se refere apenas a corredores e sim à matriz da paisagem como um todo, pensada como o oposto à fragmentação, quanto menos conectado, mais vulnerável à perda da função ecológica devido a distúrbios naturais e humanos (BENEDICT; McMAHON; 2006 p. 111). 
Os Estados da Flórida e Maryland desenvolveram modelos de InfraestruturaVerde que adotam cinco passos: desenvolver objetivos para o projeto da rede e identificar os elementos desejados, reunir e processar dados sobre tipos de paisagem, identificar e conectar elementos da rede, definir prioridades para as ações de conservação e por último, revisar e buscar colaborações.

Embora sem importância ecológica, áreas culturais e históricas com implicações na conservação de ecossistemas e restauração dos mesmos devem ser mapeadas. Exemplos destas áreas são os sítios históricos, arqueológicos, antigos campos de batalha e até cemitérios. Todos são importantes atributos das redes de Infraestrutura Verde, pois propiciam benefícios às comunidades e auxiliam no ganho de seu apoio, entretanto, devem-se priorizar os atributos do ecossistema natural.

Após a definição dos objetivos, o próximo passo é a identificação dos tipos de paisagem dentro da área de estudo. Ela dá o racional para se determinar quais os atributos devem ser incluídos e conectados dentro da Infraestrutura Verde. Forman (1995) define a paisagem como "um mosaico de ecossistemas ou usos do solo que possuem atributos comuns que são repetidos por uma grande área." Podem ser categorizados de diversas maneiras, dependendo da extensão geográfica da área de projeto, da escala em que se trabalha e dos resultados esperados (BENEDICT; McMAHON; 2006 p. 120).

Além dos atributos ecológicos, devem ser mapeados os atributos relacionados às paisagens de domínio do homem. Um exemplo disso são as terras destinadas à agricultura que ajudam a amortecer os efeitos da urbanização crescente sobre as áreas de conservação. Estas áreas podem servir de âncoras e servir de suporte à vida selvagem que necessita de grandes extensões de terras para sobreviver.

Em seguida, deve-se identificar e conectar os elementos da rede da Infraestrutura Verde. As áreas maiores e de maior qualidade são definidas como âncoras e a ligação entre elas através da paisagem determina o próximo passo. Como método, as redes podem ser desenhadas através de geoprocessamento ou à mão, tendo um mapa como base, sendo melhor utilizar as duas técnicas juntas na identificação de prioridades para encontrar a melhor localização para a âncora de transporte, analisar o dano ambiental ou acessar o padrão do desenvolvimento urbano adequado (BENEDICT; McMAHON; 2006 p. 123). 


\subsection{1 ÂNCORAS}

As âncoras podem atingir uma variedade de objetivos, como oferecer habitat para animais e plantas nativas, permitir o funcionamento de processos ecológicos sem distúrbios e prover uma origem e destino para a vida selvagem e as pessoas que se movimentam dentro do sistema. Como exemplos de âncoras podem ser citados as reservas, os parques nacionais que são os grandes blocos de construção para uma rede baseada em ecologia. 0 tamanho varia de acordo com a extensão da rede e os objetivos estabelecidos.

Para o caso de Itaquera, área de estudo da pesquisa, o Parque do Carmo e a Várzea do Tietê podem ser classificados como duas âncoras importantes.

\subsubsection{CONEXÕES LINKS}

As conexões aperfeiçoam o planejamento da paisagem quando ligam as âncoras a usos do solo apropriados ao sistema de conservação integrado. É importante observar que as conexões têm que ser embasadas cientificamente, não se tratando apenas de ligar um ponto a outro. É preciso entender as características de cada âncora, quando as âncoras são muito diferentes em termos de espécies ou da hidrologia não devem ser conectadas.

A largura das conexões entre as âncoras não segue um padrão; em geral, quanto maior sua largura melhor, especialmente quando estas conexões se prolongam por grandes extensões. Quando não for possível a continuidade, pequenos espaços, próximos uns aos outros podem ser suficientes para o movimento das espécies. É fundamental identificar áreas que possam ser incorporadas para se expandir as ligações que são tão importantes quanto as âncoras. A conectividade da rede é um sinal de bom desempenho e saúde, assim como a existência de múltiplos corredores.

\subsection{A IMPLANTAÇÃO DA INFRAESTRUTURA VERDE}

A implantação da Infraestrutura Verde é um processo complexo, pois envolve agentes públicos e privados. As âncoras possuem dimensões variadas e incluem diversos tipos de 
Tabela 3.2 -

As ferramentas para implantação da Infraestrutura Verde (BENEDICT; McMAHON; 2006.

Tradução nossa) paisagem e as conexões podem ser insuficientes ou necessitarem ser restauradas. Integrar as ações de grupos diferentes com o objetivo da conservação começa com a identificação dos mesmos e a canalização de seus esforços para se atingir objetivos comuns com a articulação de ferramentas como programas, recursos financeiros e a formulação de nova legislação.

As ferramentas para implantação da Infraestrutura Verde e para se proteger as áreas a serem conservadas são: aquisição de áreas prioritárias, regulamentação e criação de incentivos e financiamento. O quadro ideal consiste na articulação de mais de uma ferramenta.

A tabela a seguir foi elaborada por Mark Benedict e Edward McMahon, com a exemplificação destas ferramentas (BENEDICT; McMAHON; 2006 p. 153, 154).

\begin{tabular}{|c|c|c|c|c|}
\hline & Local & Estado & Federal & Privado \\
\hline $\begin{array}{l}\text { Aquisição de } \\
\text { terras }\end{array}$ & $\begin{array}{l}\text { - Tarifa simples de } \\
\text { aquisição } \\
\text { - Conservação e ou faixas } \\
\text { livres de agricultura } \\
\text { - Compra de direitos para } \\
\text { empreendimentos } \\
\text { - Transferência de direitos } \\
\text { de empreendimentos }\end{array}$ & $\begin{array}{l}\text { - Conservação de faixas } \\
\text { livres, recuos } \\
\text { - Tarifas simples de } \\
\text { aquisição } \\
\text { - Programa de Legado de } \\
\text { Floresta } \\
\text { - Amortecimento dos sítios } \\
\text { de preservação histórica } \\
\text { - Iniciativas de Crescimento } \\
\text { Inteligente }\end{array}$ & $\begin{array}{l}\text { - Fundos para conservação } \\
\text { de terras e água } \\
\text { - Tarifa simples de } \\
\text { aquisição } \\
\text { - Recuos, faixas livres para } \\
\text { conservação } \\
\text { - Lei para proteção de } \\
\text { terras agriculturáveis } \\
\text { - Prêmios para } \\
\text { desenvolvimento de } \\
\text { quadras dentro das } \\
\text { comunidades }\end{array}$ & $\begin{array}{l}\text { - Recuos, faixas livres para } \\
\text { conservação } \\
\text { - Conservação e estoque } \\
\text { de alagados } \\
\text { - Tarifa simples de compra } \\
\text { - Corporações locais } \\
\text { - Fundos de propriedade } \\
\text { locais } \\
\text { - Fundo de propriedades } \\
\text { nacionais } \\
\text { - Recuos e faixas livres para } \\
\text { vegetação ripária }\end{array}$ \\
\hline Regulamentação & $\begin{array}{l}\text { - Marcos regulatórios para } \\
\text { a paisagem e seu } \\
\text { amortecimento } \\
\text { - Código de obras } \\
\text { - Plantas completas } \\
\text { - Bancos de conservação } \\
\text { - Tarifas sobre impacto de } \\
\text { empreendimentos } \\
\text { - Leis para impacto } \\
\text { ambiental } \\
\text { - Banco de mitigação } \\
\text { - Distritos especiais } \\
\text { - Leis para sistema de }\end{array}$ & $\begin{array}{l}\text { - Leis para rodovias cênicas } \\
\text { - Leis para rios cênicos } \\
\text { - Bancos de conservação e } \\
\text { mitigação } \\
\text { - Programas para } \\
\text { regulamentação de } \\
\text { recuos de rios e alagados } \\
\text { - Programas para } \\
\text { aprovação de espécies } \\
\text { raras ou em risco de } \\
\text { extinção } \\
\text { - Programas para } \\
\text { aprovação de }\end{array}$ & $\begin{array}{l}\text { - Lei do ar limpo } \\
\text { - Lei da água limpa } \\
\text { - Lei das espécies em } \\
\text { extinção } \\
\text { - Lei de proteção nacional } \\
\text { do meio ambiente } \\
\text { - Marcos históricos } \\
\text { nacionais } \\
\text { - Marcos naturais nacionais } \\
\text { - Administração oceânica } \\
\text { e atmosférica nacional } \\
\text { - Registro nacional de sítios } \\
\text { históricos }\end{array}$ & $\begin{array}{l}\text { - Bancos de mitigação } \\
\text { privados } \\
\text { - Programa de remediação } \\
\text { privados ou de órgãos } \\
\text { não governamen-tais } \\
\text { ONGs para regulamentar } \\
\text { violações }\end{array}$ \\
\hline
\end{tabular}




\begin{tabular}{|c|c|c|c|c|}
\hline & Local & Estado & Federal & Privado \\
\hline & $\begin{array}{l}\text { águas pluviais } \\
\text { - Marcos regulatórios para } \\
\text { condomínios } \\
\text {-Zoneamento incluindo } \\
\text { espaços livres e } \\
\text { desempenho de } \\
\text { zoneamento }\end{array}$ & $\begin{array}{l}\text { gerenciamento de água e } \\
\text { recurso de água }\end{array}$ & $\begin{array}{l}\text { - Lei da água potável } \\
\text { - Lei dos rios cênicos }\end{array}$ & \\
\hline Incentivos & $\begin{array}{l}\text { - Acordos de } \\
\text { gerenciamento } \\
\text { - Reconhecimento e } \\
\text { premiações de educação } \\
\text { - Incentivos fiscais; } \\
\text { estratégias de } \\
\text { gerenciamento estaduais } \\
\text { - Apoio governamental } \\
\text { local e assistência técnica }\end{array}$ & $\begin{array}{l}\text { - Gerenciamento de } \\
\text { melhores práticas } \\
\text { - Iniciativas de Crescimento } \\
\text { Inteligente } \\
\text { - Benefícios fiscais }\end{array}$ & $\begin{array}{l}\text { - Gerenciamento de } \\
\text { melhores práticas de } \\
\text { agricultura } \\
\text { - Programa de conservação } \\
\text { de reserva e } \\
\text { melhoramento } \\
\text { - Programa de incentivos } \\
\text { para qualidade ambiental } \\
\text { - Programa de seguro } \\
\text { contra enchentes da } \\
\text { Defesa Civil } \\
\text { - Programa de incentivo } \\
\text { aos proprietários } \\
\text { - Parceiros para a vida } \\
\text { selvagem } \\
\text { - Programa federal de } \\
\text { banco de água e crédito } \\
\text { de refloresta-mento } \\
\text { - Programa de reserva de } \\
\text { alagados } \\
\text { - Benefícios fiscais }\end{array}$ & $\begin{array}{l}\text { - Banco de conservação e } \\
\text { alagados } \\
\text {-Trading ambiental } \\
\text { - Reconheci-mento do } \\
\text { proprietário } \\
\text { - Fundação de conservação } \\
\text { - Conservação da natureza }\end{array}$ \\
\hline Financiamento & $\begin{array}{l}\text { - Taxas para } \\
\text { empreendedores } \\
\text { - Taxas para impacto } \\
\text { ambiental } \\
\text { - Lei orçamentária } \\
\text { ambiental } \\
\text { - Lei orçamentária para } \\
\text { proteção de espaços } \\
\text { livres } \\
\text { - Taxas especiais } \\
\text { - Imposto de transferência }\end{array}$ & $\begin{array}{l}\text { - Imposto de transferência } \\
\text { - Fundo de liquidez de } \\
\text { transporte } \\
\text { - Fundo de melhoria de } \\
\text { transporte }\end{array}$ & $\begin{array}{l}\text { - Lei do ar limpo } \\
\text { - Lei da água limpa } \\
\text { - Fundo de cooperação } \\
\text { para espécies em extinção } \\
\text { - Incentivos de qualidade } \\
\text { ambiental } \\
\text { - Lei de proteção de terras } \\
\text { agriculturáveis } \\
\text { - Programa de incentivos } \\
\text { para proprietários } \\
\text { - Fundo de conservação } \\
\text { para pássaros migratórios } \\
\text { - Lei de conservação dos } \\
\text { alagados norte } \\
\text { americanos } \\
\text { - Parceiros para visa } \\
\text { selvagem } \\
\text { - Fundos estaduais } \\
\text { - Lei de transporte }\end{array}$ & $\begin{array}{l}\text { - Fundação para terras } \\
\text { públicas } \\
\text { - Fundação para terras } \\
\text { locais, regionais e } \\
\text { estaduais }\end{array}$ \\
\hline
\end{tabular}


A participação comunitária é fundamental para a implantação da Infraestrutura Verde e deve ocorrer em todas as fases do projeto. O compromisso no longo prazo e a regulamentação através de leis garantem o estabelecimento do projeto de Infraestrutura Verde fundamental para a criação de centros urbanos, cuja estrutura seja condizente e equilibrada com a capacidade de suporte da natureza, onde esta guia o desenvolvimento, princípio básico do Urbanismo Ecológico. 


\section{CAPÍTULO 4}

\section{O CONCEITO DA AGRICULTURA URBANA COMUNITÁRIA COMO ESTRATÉGIA DE INFRAESTRUTURA VERDE NOS BAIRROS}

4.1 O DESENVOLVIMENTO URBANO ECOLÓGICO E OS JARDINS COMUNITÁRIOS

4.2 O PROJETO DE JARDINS COMUNITÁRIOS

4.3 ESTUDOS DE CASO NA CIDADE DE SEATTLE, ESTADOS UNIDOS

4.3.1 HISTÓRICO

4.3.2 O PROGRAMA P-PATCH E SUA CONTRIBUIÇÃO PARA A INFRAESTRUTURA VERDE DE SEATTLE

4.3.3 DANNY WOO INTERNATIONAL COMMUNITY

4.3.4 BRADNER GARDENS PARK

4.3.5 BELLTOWN P-PATCH

4.3.6 INTERBAY P-PATCH

4.3.7 CASCADE P-PATCH

4.4 O CRESCIMENTO DA AGRICULTURA URBANA 
Este capítulo tem como objetivo apresentar a agricultura urbana como parte do conceito de desenvolvimento sustentável através da qual se constroem comunidades e seus bairros.

O capítulo ilustra experiências de engajamento, de cidadania e exemplos da produção de alimentos dentro de centros urbanos. Sua implantação é uma alternativa ao deslocamento dos produtos por quilômetros e, consequentemente, minimiza seus impactos ambientais, emissão de $\mathrm{CO} 2$, além de promover a reativação de usos de solos subutilizados dentro do tecido urbano. $\mathrm{O}$ aspecto socioeconômico é tratado como componente fundamental através dos estudos de caso aqui apresentados.

Uma refeição típica americana viaja 2400 quilômetros da fazenda até chegar ao prato, o que resulta em um grande consumo de energia para o transporte e para a refrigeração. Com o aumento do custo da energia, a região metropolitana, através da esfera estadual deve preservar áreas agriculturáveis para suprir em parte o seu consumo.

Em Novembro de 2011, realizei uma série de visitas programadas à cidade de Seattle, com especial atenção ao Programa da Prefeitura P-Patch. O diretor do Departamento de Arquitetura Paisagística da Universidade de Washington e autor do livro Greening cities, Growing communities Jeffrey Hou (HOU; JOHNSON; LAWSON, 2009) apoiou esta pesquisa fornecendo dados e endereços sobre 5 projetos: Danny Woo International Community Gardens, Bradner Gardens Parks, Marra Farms, Belltown P-Patch, Cascade P-Patch e Interbay P-Patch.

Trata-se de uma série de jardins comunitários (community gardens), de diferentes escalas e inserção em vizinhanças distintas. Para escrever o seu livro, que também ressalta outras experiências nos Estados Unidos, o autor contou com o apoio do Departamento de Arquitetura Paisagística da Universidade de Washington e do Departamento de Arquitetura Paisagística da Universidade de Illinois, dos usuários dos jardins comunitários, de funcionários do P-Patch, P-Patch Trust e do Departamento de bairros (Department of Neighborhoods) de Seattle.

Adotarei a denominação “jardins comunitários" como tradução direta do termo em inglês community gardens, entretanto, estes espaços possuem um programa de necessidades variado que extrapolam hortas, pomares e canteiros ornamentais. Alguns deles fazem parte de parques públicos ou até mesmo, constituem isoladamente espaços públicos importantes nos 
bairros, sendo eles cercados ou não. O papel destes espaços vai além da questão produtiva, assumindo socialmente função ativa. O desenho em si é simples e claro, baseado em sua maioria em um zoneamento racional e funcionalista.

O projeto de jardins comunitários nos Estados Unidos surgiu a partir da iniciativa de residentes em busca de alternativas de uso para espaços livres urbanos e de instituições que precisavam de locais para desenvolver seus programas de capacitação e formação de jardineiros, de terapia através da prática de jardinagem. As agências públicas também viram na prática da agricultura o desenvolvimento de atividades complementares ao esporte, como parte integrante do cotidiano de espaços públicos voltados para a recreação e o lazer.

A transformação da paisagem, perceptível da semente à muda adulta, a produtividade do cultivo, a melhoria da nutrição motivaram os usuários com o objetivo comum de construir uma comunidade mais saudável.

A presença de jardins comunitários na história americana é identificada desde 1890. Com a urbanização crescente surgiram vários programas com objetivos que variavam do uso de lotes subutilizados para educação ambiental nas escolas até o embelezamento dos bairros, geração de empregos durante a Depressão de 1930, como fonte de alimentos durante a Primeira Guerra Mundial ou mesmo como espaços para jardins cívicos e comemorativos das vitórias da Segunda Guerra Mundial. Atualmente vigora o movimento pelos jardins comunitários nos centros urbanos, como grande articulador para a manutenção e criação de novos programas (LAWSON, 2005).

O historiador norte americano Thomas Bassett descreve jardins comunitários como uma estratégia de apoio a sistemas culturais durante os períodos de crise socioeconômica. Um indivíduo sabe que pode fazer diferença na comunidade em que vive diferentemente do que a sua atuação colabora na solução de problemas maiores como guerras ou outras crises globais. É uma questão de contribuição e escala.

A forma de se implementar e sustentar os programas também varia. Até a década de 1960 muitos jardins eram criados por iniciativa de educadores e líderes comunitários como uma forma de servir um espectro bem maior de cidadãos. Escolas e Associações assumiam o 
papel de adquirir propriedades, contratar mão de obra, especialmente supervisores e promover a participação.

O programa de jardinagem do Departamento de agricultura do Governo Federal dos Estados Unidos (Federal United States Department of Agriculture's Urban Gardening Program) ACGA e outras instituições governamentais apoiaram as ações entre 1960 e 1970, com o objetivo de solucionar questões sociais como o aumento da inflação, o estabelecimento de uma nova ética ambiental e a falta de investimentos com a finalidade de criar recursos permanentes e prover um leque de benefícios mais amplo aos bairros (HOU; JOHNSON; LAWSON, 2009).

Atualmente, os jardins comunitários incluem-se no programa de espaços públicos nas cidades, que cada vez mais buscam nestas áreas contrapartida no âmbito ambiental e social em resposta à urbanização crescente. Áreas verdes e espaços públicos assumem um papel fundamental para a qualidade de vida nos centros urbanos.

Em Nova lorque, em 1984, um levantamento apontou a existência de 448 jardins comunitários e parques, totalizando cerca de 62 hectares servindo cerca de 11.171 pessoas. Mark Francis, arquiteto paisagista, professor e ex-diretor do programa de Arquitetura Paisagística da Universidade da Califórnia em Davis (U.C. Davis) conceitua jardins comunitários como parte de um sistema alternativo de parques urbanos, caracterizado pela participação de residentes em sua criação em lotes vazios, com um programa que pode incluir desde áreas de contemplação, parque infantil e jardins comunitários, frequentemente lotes privados muitas vezes não vistos como parte do sistema de espaços livres das cidades e muitas vezes com o tempo substituídos por outros usos como moradia e empreendimentos comerciais (FRANCIS, 1984).

Devido à grande demanda de espaços para recreação e lazer nas vizinhanças, algumas secretarias municipais também apoiaram a iniciativa dos residentes na criação de pocket parks, parques infantis de aventura, praças e jardins comunitários.

Apesar de não haver dados hoje sobre o número de jardins comunitários nos Estados Unidos sabe-se que o movimento ainda é muito difundido. A ACGA, em 1999, divulgou um relatório que listou cerca de 700 associações que representavam meio milhão de pessoas em quase todos os Estados. Foram identificados cerca de 6.020 jardins somando os espaços públicos 
dentro das vizinhanças, jardins em escolas, casas de reabilitação e repouso etc. As cidades, na época do levantamento que possuíam a maior quantidade destes espaços, eram Nova lorque com 1906 jardins seguida por Newark com 1308, Filadélfia com 1135, Minneápolis com 536 e Boston com 148.

\subsection{O URBANISMO ECOLÓGICO E OS JARDINS COMUNITÁRIOS}

O debate sobre a aplicação do conceito de sustentabilidade no planejamento urbano não é recente. A conexão entre aspectos sociais, econômicos e ambientais é fundamental na criação de centros urbanos mais equilibrados e que deem condições saudáveis para as futuras gerações. Em uma escala relativamente pequena, tal conceito é claramente identificado nos projetos de jardins comunitários que, sob o aspecto produtivo, têm o objetivo da redução de consumo, consome-se apenas o que pode ser produzido.

Uma vez escolhido o terreno, na maioria das vezes através de um arrendamento por período curto e determinado, em propriedades privadas, sem uso, quando são negociados valores simbólicos ou até doações com a condição de deixarem o terreno em bom estado na devolução. Para os participantes, a contribuição de um dólar por ano é bem atrativa e por outro lado, para o proprietário e a Prefeitura, é uma boa forma de se manter o terreno sem prejudicar um possível empreendimento no futuro.

Outra forma de implantação dos jardins produtivos é a integração destes no sistema de espaços públicos, seja em propriedades ainda sem projeto pelo departamento de parques, seja na incorporação deste elemento em parques existentes. Neste caso, o jardim passa a complementar outras atividades como brincadeiras em parques infantis, esportes e usos culturais. A controvérsia em torno desta opção se relaciona com o fato de alguns indivíduos se incomodarem com apropriação individual para consumo próprio de um espaço público. Tal situação é comparada pelos participantes do programa com atividades esportivas excludentes como campos de golfe e quadras de tênis em parques e amenizada pela promoção de programas educacionais, oficinas, visitas guiadas e eventos especiais na área dos canteiros de hortaliças, frutíferas etc. 
Alguns grupos mais organizados adquirem a propriedade conjuntamente, como organizações não governamentais. Segundo dados oficiais, estas iniciativas representam cerca de $5 \%$ dos jardins comunitários em 38 cidades, embora positivas, elas geraram discussão a respeito de segregação, pois muitos habitantes desprovidos de recursos financeiros ou relações políticas continuaram não tendo acesso.

Atualmente, como forma de resolver esta questão, parcerias público privadas mostramse como alternativa para aquisição de terras. Em troca do investimento, os usuários se comprometem a criar uma estrutura organizada para manutenção, segurança e garantia de acesso público.

\subsection{O PROJETO DE JARDINS COMUNITÁRIOS}

O projeto dos jardins comunitários também é resultado de um processo participativo no qual os próprios participantes fazem a configuração do terreno, determinando as áreas destinadas à horta, pomar, parque infantis, acessos. Em outros casos, um plano diretor é elaborado para o lote com diretrizes de ocupação e a descrição das etapas por fase a serem executadas, quando os recursos não são suficientes para a elaboração total do projeto. Frequentemente, os futuros jardineiros recebem ajuda de instituições públicas para o projeto, através de cessão de profissionais, como arquitetos paisagistas de seus quadros para elaboração do plano diretor. Estes profissionais são contratados ou até mês doam os seus honorários.

Embora o programa de projeto varie de acordo com as necessidades da população local, há elementos comuns como a verificação das condições do solo, clima, ventos predominantes, acesso à água. Uma vez verificados estes fatores, elabora-se a configuração das áreas de produção, áreas para compostagem, caminhos e áreas comuns. O tamanho e a configuração dos canteiros variam de acordo com o terreno e a comunidade. Alguns têm jardineiras construídas com madeira, outros somente com canteiros de solo e acesso para pessoas com mobilidade reduzida. 

do jardim comunitário de Cascade em Seattle, diretrizes de sustentabilidade. Foto: Patrícia Akinaga.
O projeto do perímetro é cuidadosamente estudado, pois reflete a "fachada" do terreno, sua interface com a vizinhança. Através do desenho de bordas atraentes, organizadas, com ótimo estado de conservação e limpeza busca-se aguçar a percepção da comunidade com relação à importância da presença deste tipo de espaço dentro do bairro. Muitos projetos apresentam o plantio de espécies ornamentais, com flores, frutos e ervas de tempero ao longo do perímetro que não só tornam o local agradável, mas permitem que os pedestres possam ter acesso e até provar os frutos como parte da experiência. Em bairros onde a incidência de vandalismo é maior, verifica-se a instalação de cercas, por vezes altas e com portões o que prejudica a relação com a comunidade e pode induzir a mais violência (figura 8).

O programa ainda pode englobar pequenas construções para o abrigo de ferramentas, reuniões, quadros de aviso, arte pública e local para coleta de águas pluviais para reuso em irrigação, de forma a exercer a função de educação ambiental com placas de sinalização e comunicação visual projetada (figura 7).

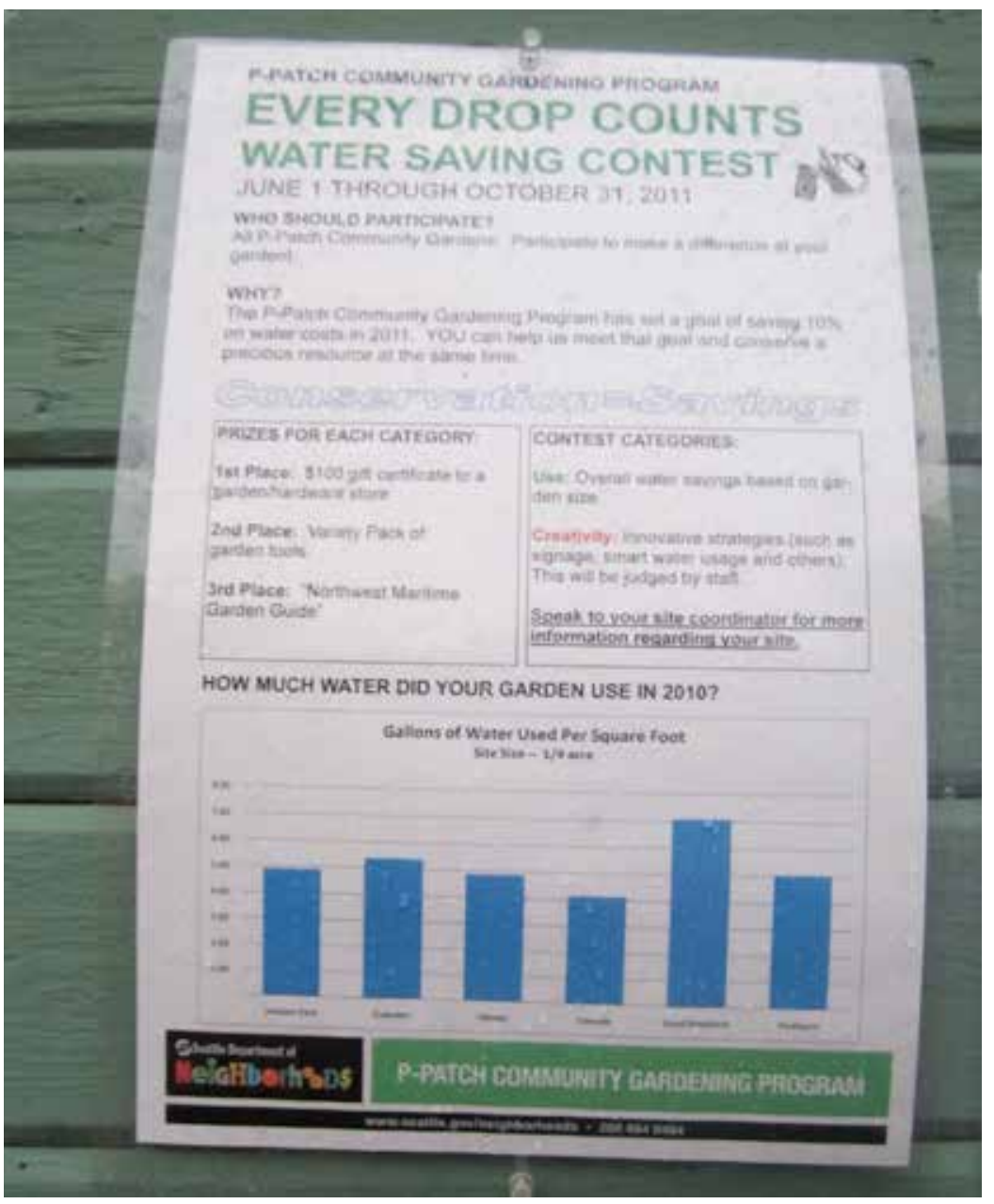


Spirn (1995) considera o projeto do jardim como reflexo do processo de sua elaboração, por exemplo, um jardim construído com eficiência e segmentado, criado por muitas pessoas, em contraponto a um projeto mais amorfo e fluído que ilustra um só conceito, resultado de um consenso.

Árvores ou espécies lenhosas normalmente não são permitidas junto aos canteiros de produção por produzirem sombra e prejudicar o crescimento de hortaliças e temperos, também é em alguns casos restringido o uso de pesticidas para a produção de orgânicos.

Árvores ornamentais e frutíferas são plantadas próximas ao parque infantil e outras áreas comuns para sombreamento e estruturação dos espaços. Ao contrário de quadras poliesportivas, subutilizadas em algumas estações do ano e abandonadas ao tempo, as áreas de jardim devem ser mantidas o ano inteiro, por isso a necessidade do envolvimento da comunidade como processo constante, com uma liderança definida e organizada.

Figura 8: Cascade P-Patch Garden, portal de entrada. Foto: Patrícia Akinaga.

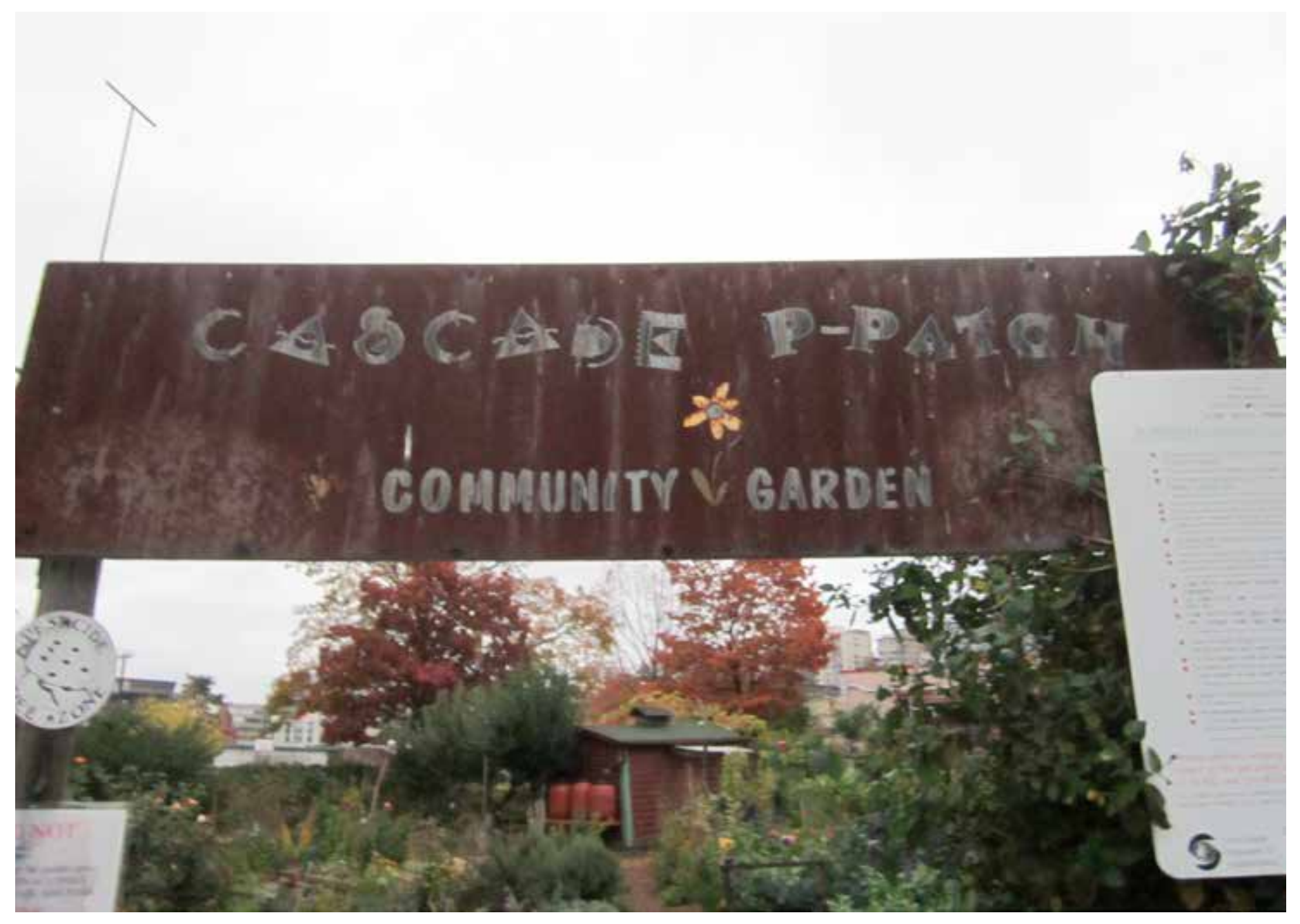




\subsection{ESTUDOS DE CASO NA CIDADE DE SEATTLE, ESTADOS UNIDOS}

\subsubsection{HISTÓRICO}

Os jardins comunitários em Seattle fazem parte de sua paisagem desde a década de 70, onde há condições favoráveis como clima ameno e estações do ano bem definidas. A topografia e hidrografia também foram fatores preponderantes, como os cursos d'água que formam uma rede com nascente nas montanhas Cascade e percurso até Puget Sound, irrigando terras férteis em seus vales.

A vocação para agricultura se firmou com mais de 3000 fazendeiros próximos ao centro de consumo no início do século XX. Conforme Seattle cresceu, não fugiu a regra do processo de muitas cidades onde as terras produtivas foram substituídas por usos industriais, residenciais, comerciais, entretanto, algumas propriedades foram mantidas para jardins comunitários, fruto do ativismo conhecido dos habitantes da cidade.

No final do século XIXe a corrida de ouro para o Alaska, a cidade assumiu posição estratégica militar e também recebeu imigrantes e migrantes em busca de novos desafios. Durante a Segunda Guerra Mundial a economia se sustentou com a indústria naval e aérea.

Atualmente a economia de Seattle é caracterizada pela indústria de biotecnologia, aeroespacial e tem como destaque a sede da empresa Boeing e a instalação de universidades importantes nas áreas de tecnologia e artes. Em termos de etnia, em 2000, de acordo com os dados do senso, $70 \%$ de sua população era constituída por brancos, sendo os asiáticos o primeiro grupo dominante nas minorias. Em 2005 sua população já atingia a marca de 573.000 pessoas na cidade e aproximadamente 3.5 milhões na área metropolitana (HOU; JOHNSON; LAWSON, 2009).

O fenômeno de gentrificação e a crescente disparidade entre ricos e pobres preocupa o poder público, principalmente com o aumento da pobreza. O número de pessoas vivendo abaixo da linha de pobreza é maior entre os imigrantes que chegaram à cidade após 1995. Apesar da retração na economia, o preço dos imóveis continuou a crescer e a população carente, antes habitante do centro, passou a ser deslocada para a periferia e suas áreas ocupadas por novos empreendimentos. 
As características do desenho urbano de Seattle estão relacionadas à topografia da cidade. Nos morros, localizam-se os bairros de Queen Anne Hill, Capitol Hill e Beacon Hill, nos vales ficam os bairros de Rainier Valley, Madison Valley e Interbay.

Seattle é conhecida por suas iniciativas inovadoras com relação ao meio ambiente que se refletiu na criação de um sistema consistente de áreas verdes e sistemas alternativos de drenagem através de jardins de chuva (rain gardens). A cidade é cercada por uma paisagem natural rica constituída de rios, o oceano Pacífico, áreas de mata preservadas e os bairros são servidos por parques, ciclovias e ruas adequadas ao pedestre, com calçadas amplas e arborização.

Os jardins comunitários da cidade, durante a Segunda Guerra Mundial, desempenharam papel importante junto ao esforço nacional de produção de alimentos local através da criação de jardins da vitória nos quintais, universidades e escolas, parques e outras propriedades públicas.

O primeiro deles surgiu em uma área antes ocupada por uma fazenda de Rainie Picardo e no Verão de 1971 foi mantido por uma escola como parte do programa Neighbors in Need. Com o apoio de uma cooperativa, em 1973, o proprietário considerou vendê-la devido aos impostos territoriais, mas a Câmara dos Vereadores resolveu arrendar como experimento sobre a supervisão do Departamento de Parques e Recreação e o Departamento de Juventude. $O$ terreno foi dividido em 195 canteiros de 37 metros quadrados cada e 14 canteiros para jovens. A primeira colheita foi celebrada com um almoço vegetariano com a presença do Prefeito, de representantes da Câmara e mais de 60 jardineiros (HOU; JOHNSON; LAWSON, 2009).

A divulgação ampla da mídia ajudou na difusão da iniciativa em outros bairros e uma comissão formada por membros indicados da Câmara e de representantes de outras agências públicas desenvolveu o Programa denominado P-Patch em homenagem a Picardo, liderado pelo Departamento de Recursos Humanos. O programa se expandiu com a Prefeitura cedendo inicialmente sementes, fertilizantes e água. Apesar de cortes no orçamento ao longo do tempo, o programa se manteve com uma equipe de dois profissionais da Prefeitura e muitos voluntários com programas para educação, fornecimento de alimentos para abrigos aos mendigos, capacitação de jovens, serviços para a terceira idade e para novos imigrantes. Em 1997, o programa foi transferido para o Departamento de Bairros onde permanece até hoje. 


\subsubsection{O PROGRAMA P-PATCH E SUA CONTRIBUIÇÃO PARA A INFRAESTRUTURA VERDE DE SEATTLE}

Os membros da equipe da Prefeitura auxiliam as comunidades que desejam ter um jardim do programa de diversas formas através de: coordenação de parcerias público privadas, arrecadação de fundos para programas, teste de solos e processo de projeto. Também arbitram sobre disputas e designam canteiros aos residentes interessados.

Desde 2006, o Programa P-Patch gerencia cerca de 67 jardins espalhados pela cidade, segundo Jeffrey Hou. As listas de espera para participar de um destes jardins em bairros de alta densidade pode chegar a três anos. A preferência é de quem já tem o direito de uso de um canteiro em renová-lo e um residente candidato pode se inscrever para mais de um jardim para aumentar a sua chance.

O lease é anual e o jardim deve ser mantido por todo o ano e custa de 34 dólares a 67 dólares, dependendo do tamanho do canteiro que começa com a modulação de 9 metros quadrados. A tarifa cobrada é paga pela água e fertilizantes fornecidos pela Prefeitura, e em alguns locais o usuário pode utilizar ferramentas também fornecidas por ela. Todos os jardins visitados para esta pesquisa possuíam um galpão de depósito de ferramentas identificadas com o nome do lugar.

O programa atualmente tem políticas para o cultivo de produtos orgânicos que se tornou um requisito. Os participantes não podem vender sua produção, mas podem doá-la. Além de cultivar um canteiro, o voluntário deve trabalhar no mínimo 8 horas a cada ano em áreas comuns do P-Patch para sua manutenção.

Durante 10 dias, foram visitados 06 jardins comunitários em Seattle: Danny Woo International Community Gardens, Bradner Gardens Park, Marra Farms, Belltown P-Patch, Cascade P-Patch e Interbay P-Patch. Os critérios utilizados para seleção dos estudos de caso foram a sua distinta implantação, o tipo de programa e a inserção do contexto urbano. Como parte da metodologia, foram tiradas fotografias e anotadas impressões com base em observação local. 


\subsubsection{DANNY WOO INTERNATIONAL COMMUNITY}

O jardim de Danny Woo foi inaugurado em 1976 e não faz parte do programa P-Patch. Seu entorno é caracterizado pela presença de imigrantes asiáticos e em sua maioria idosos, principais usuários do local. Gerenciado pela Associação Inter*Im de Desenvolvimento Comunitário, o jardim teve como projetistas Dan Rounds, que fez a implantação em 1980, Leslie Morishita, autora do projeto do galpão de ferramentas e a UW Neighborhood Design Build Studio.

O terreno é de propriedade de Wilma e Teresa Woo, Departamentos de Parques de Seattle e Departamento de Transportes. O terreno possui cerca de 0,60 hectares e aproximadamente 100 canteiros, conforme figura 9 . Serve uma população de 2.000 pessoas, sendo $56 \%$ desta população composta de asiáticos.

Figura 9: Mapa do jardim Danny Woo International. Foto: Patrícia Akinaga

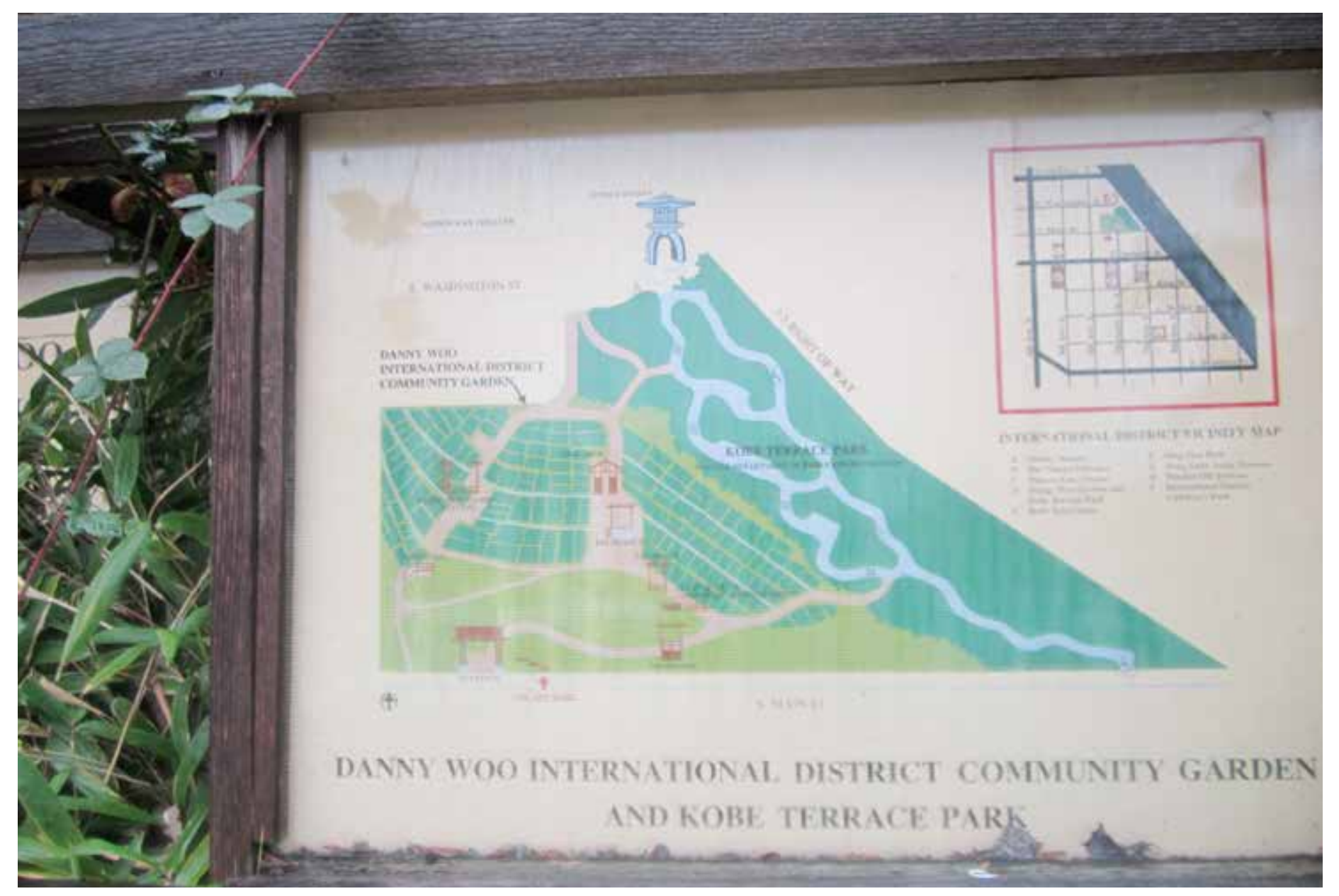


Junto ao Kobe Terrace Park, a área forma uma das mais importantes áreas verdes do Centro de Seattle. O terreno com declive acentuado foi terraceado com o uso de madeira de demolição proveniente de trilhos de trem. O cultivo é predominante de hortaliças orientais, como acelga japonesa, brotos de feijão, mostarda e agrião, produzidos por idosos asiáticos do entorno imediato. Há também árvores como cerejeiras, macieiras e pessegueiros. A herança cultural dos povos asiáticos reflete-se no desenho dos elementos como bancos, cercas e pórticos (HOU; JOHNSON; LAWSON, 2009).

$\mathrm{Na}$ área comum e social foi projetada uma churrasqueira e uma série de áreas de contemplação com decks e quiosques para visitantes e jardineiros. Por estar em uma área de morro, as vistas para a baía de Elliot são privilegiadas. Do jardim é possível avistar o centro da cidade, as Montanhas Olympic, o porto de Seattle e o estádio de futebol americano. O jardim recebe turistas e é aberto ao público, por pertencer ao Departamento de Parques.

O bairro onde está inserido International District é um dos bairros históricos mais importantes de Seattle. Recebeu desde o século XIX ondas de imigrantes como chineses, japoneses e filipinos. Durante a Segunda Guerra Mundial a comunidade perdeu muitos imigrantes japoneses bem como seus negócios, pois os mesmo foram enviados para campos de aprisionamento. Após a guerra, muitos residentes se mudaram para o subúrbio remanescendo no bairro, os mais velhos e de renda mais baixa.

No início da década de 70, em uma área de 0,60 hectares, o jardim comunitário foi criado como resultado do anseio da população idosa residente em permanecer fisicamente ativa. Nesta época, houve uma mobilização para a construção de habitação de interesse social e reação contra a construção de um estádio (HOU; JOHNSON; LAWSON, 2009).

Danny Woo era um comerciante, dono de restaurante e cedeu sua propriedade próxima à via expressa para a implantação do jardim comunitário, a princípio sob um contrato de curta duração, mas a família nunca pediu a propriedade de volta. $\mathrm{O}$ jardim recebeu seu nome como homenagem e parte de seu legado. 
Figura 10: Pórtico de entrada, desenho claramente oriental. Foto: Patrícia Akinaga

Figura 11: A comunicação visual é resultado do processo participativo. Foto: Patrícia Akinaga

No início o jardim tinha 40 canteiros. Em 1980 se expandiu para o parque Kobe Terrace, apesar de preocupar o poder público ao criar o precedente, cresceu para 100 canteiros. Foi a primeira vez que um parque foi usado para este fim na cidade.
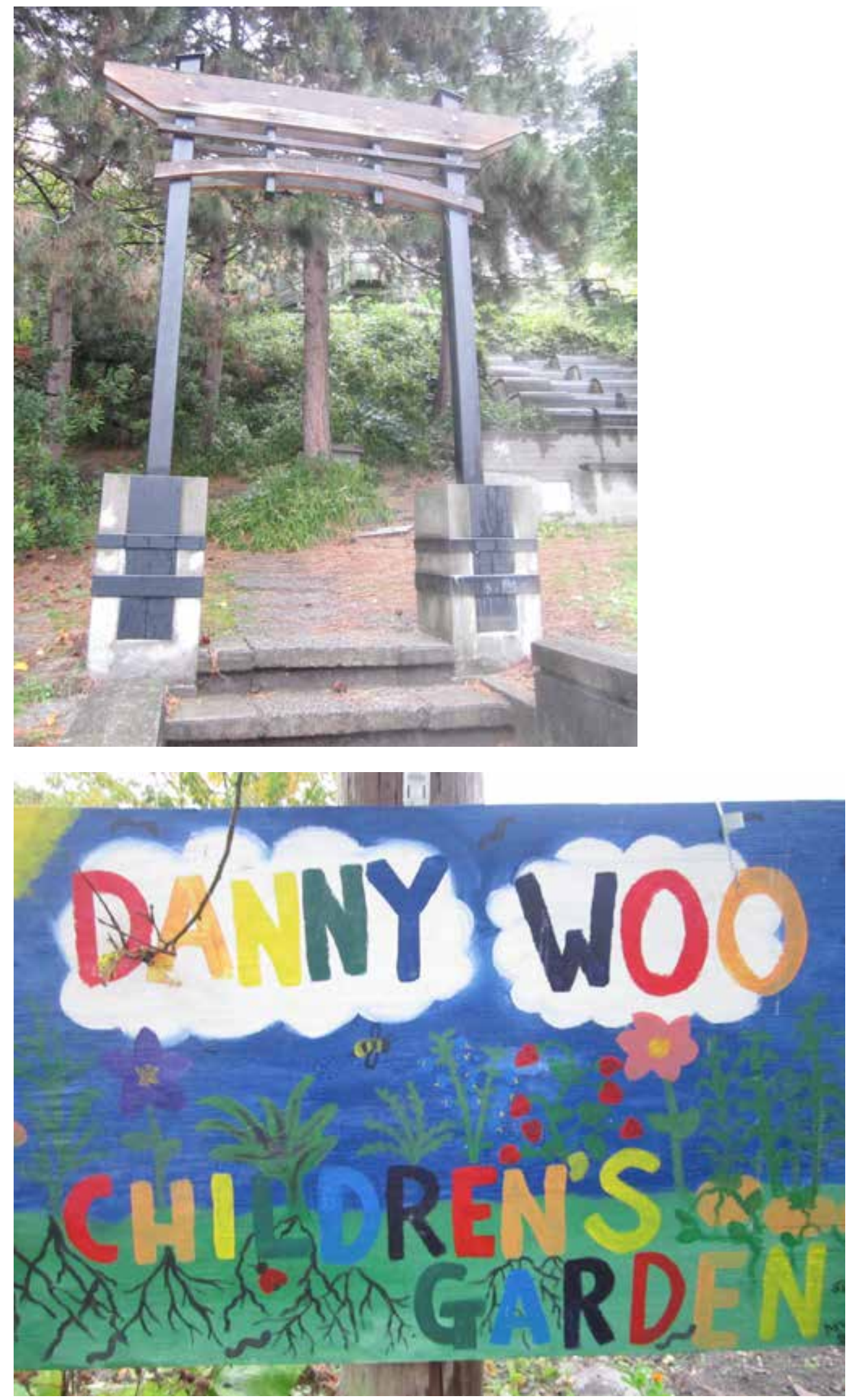

Capítulo 4 - O Conceito da agricultura urbana comunitária como estratégia de infraestrutura verde nos bairros 
Figura 12:

Canteiros em diferentes estágios de desenvolvimento. Foto: Patrícia Akinaga

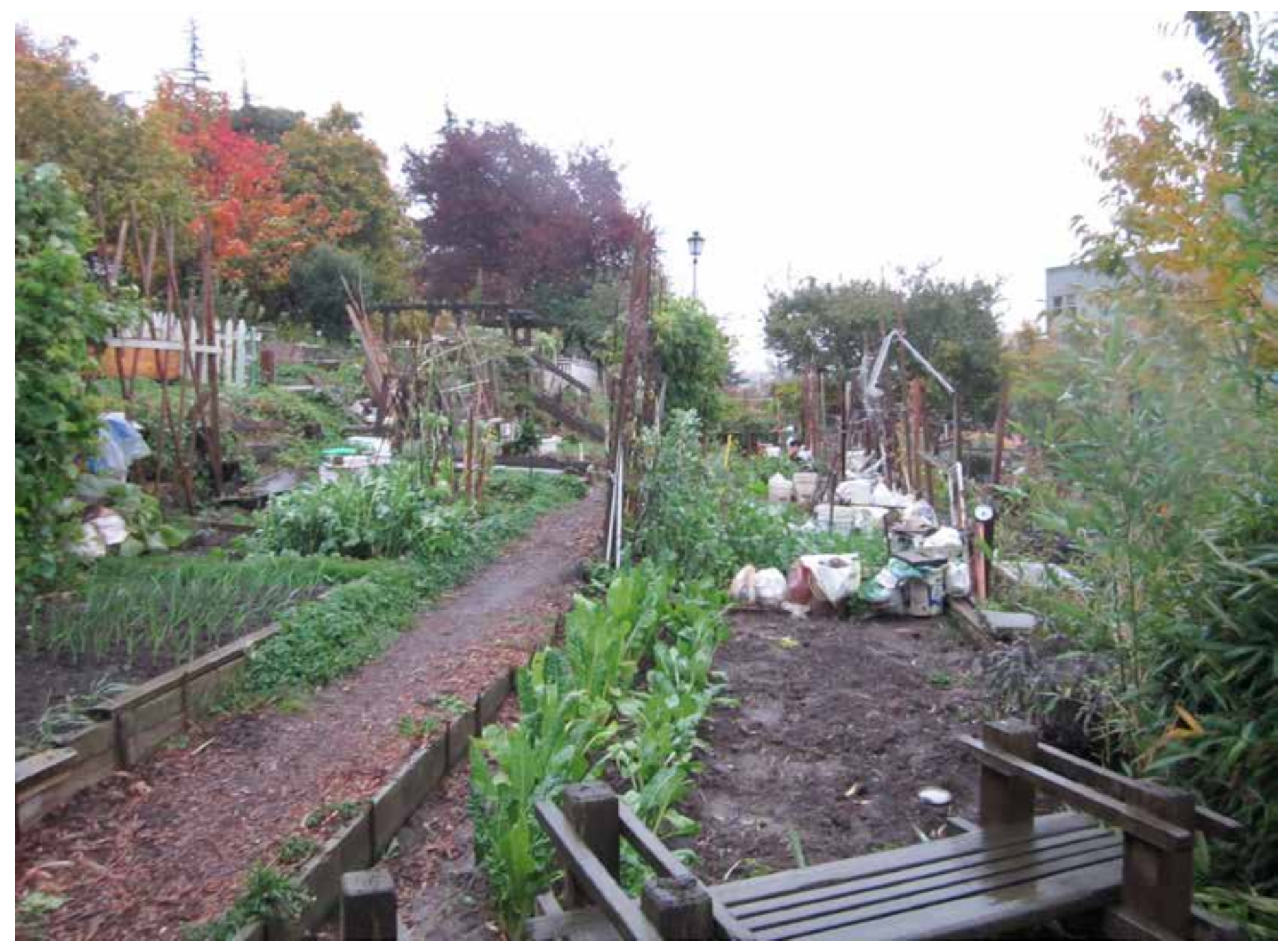

Em 1989, o Neighborhood Design Studio, com a colaboração da Universidade de Washington trabalhou com estudantes, residentes e professores que projetaram e implementaram novos elementos no jardim, como um galpão de ferramentas, um pórtico de entrada, uma churrasqueira, um local para lavagem de legumes e verduras, quiosques, recipientes para compostagem, áreas acessíveis e novos caminhos.

\subsubsection{BRADNER GARDENS PARK}

Inaugurado em 1995, o local é dividido entre as áreas de canteiros do Programa P-Patch e um parque com arte pública e áreas esportivas. $O$ projeto é resultado de um grupo e projetistas formado pelos escritórios Barker Arquitetos Paisagistas, responsável pelo Plano Mestre (Masterplan), Scott Carr do SHED Arquitetos, autor do Centro Comunitário e pela UW 
Figura 13: Arte pública como resultado do processo coletivo de construção do jardim comunitário. Fotos: Patrícia Akinaga.
Neighborhood Design/Build Studio, responsável pelo projeto e construção do pavilhão, ponte, treliças e pergolados.

A gestão é realizada pela Associação Friends of Bradner Gardens Park, com o Departamento de Parques e Recreação da Prefeitura de Seattle. O terreno possui 4.000m² e fica localizado no bairro de Mount Baker, com população de 5.717 residentes de diferentes etnias.

O espaço é rico em arte pública, seja no desenho de edificações ou mesmo na sinalização do jardim, com placas temáticas e esculturas. A vegetação e a composição com elementos lúdicos tornam este parque de vizinhança diferenciado. As vistas do parque para o centro da cidade também são privilegiadas e exploradas pelo projeto (figura 13).
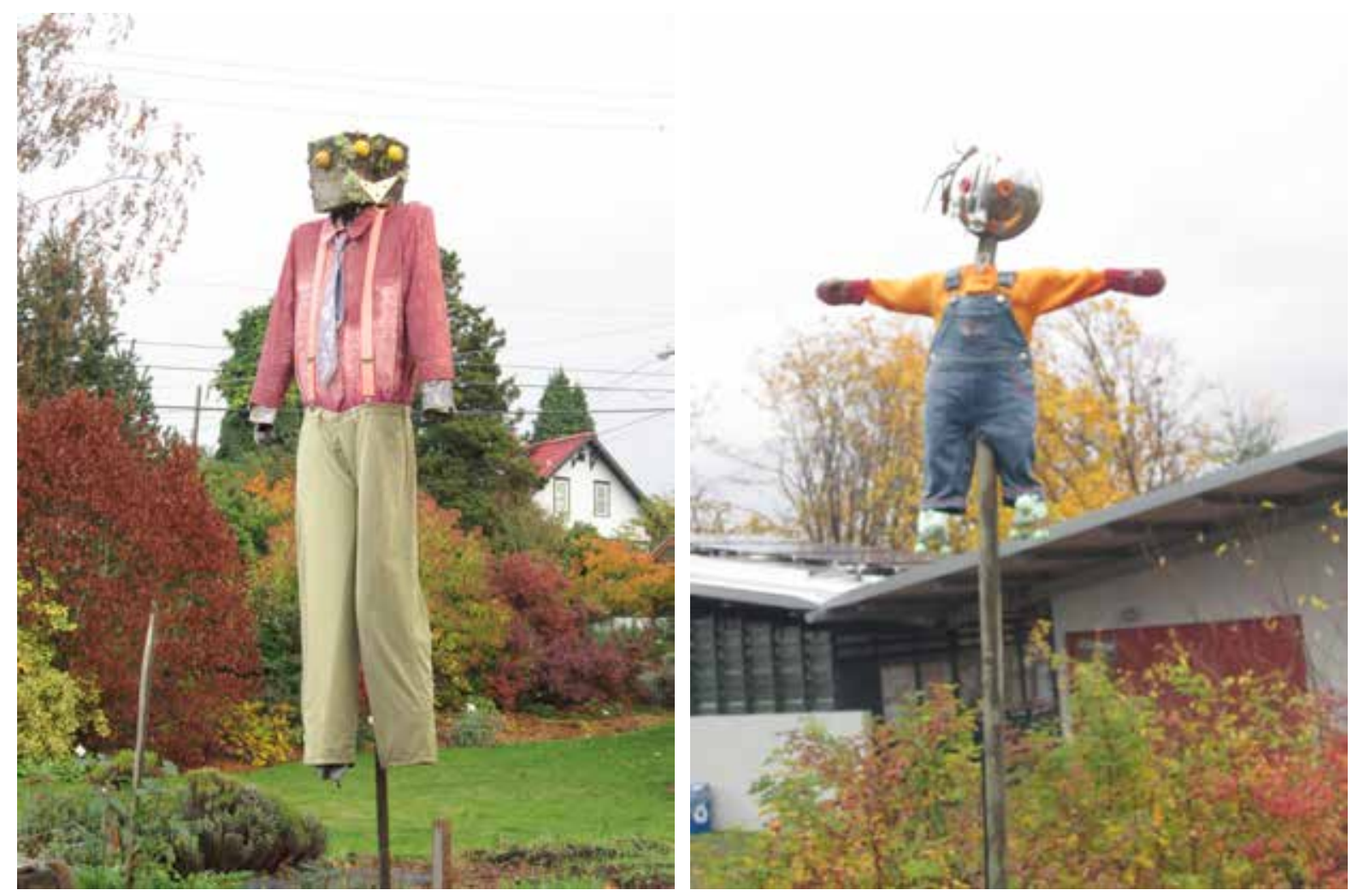

O parque tem acesso por três lados e suas entradas são valorizadas com pergolados e sinalização educativa. O tratamento paisagístico dos fechamentos é composto de plantas ornamentais e o espaçamento de plantio propicia transparência e consequente permeabilidade visual. 
Os canteiros possuem placas de identificação de espécies, o que atrai visitante e serve ao propósito educacional. Há uma série de jardins de demonstração, demonstration gardens, que são caracterizados por temas como jardins infantis, jardins orgânicos, de plantas suculentas, de clima tropical e de espécies nativas (figura 14).

$\mathrm{Na}$ entrada localizada na esquina sudeste, o visitante tem acesso através de escadas, sendo o melhor ponto de contemplação da vista para o centro da cidade de Seattle e também local para realização de eventos, reuniões etc. Além deste local, há um pavilhão central com cobertura e forma de folha, onde a comunidade pode utilizar para festas e outras confraternizações.

O parque tem um centro comunitário cuja arquitetura foi premiada pelo Instituto de Arquitetos Americanos e é utilizado para a guarda de ferramentas, reuniões e sanitários.

Na face norte do terreno, há um bosque repleto de espécies nativas com o objetivo de se tornar habitat da fauna local. Nota-se a presença de pássaros e esquilos. O plantio do bosque também funciona como zona de amortecimento entre o parque e as residências, uma vez que o parque tem atividade intensa, pois além do jardim possui quadra poliesportiva e áreas de parque infantil.

Figura 14:

Placas de sinalização e comunicação visual nos canteiros educativos. Fotos: Patrícia Akinaga.
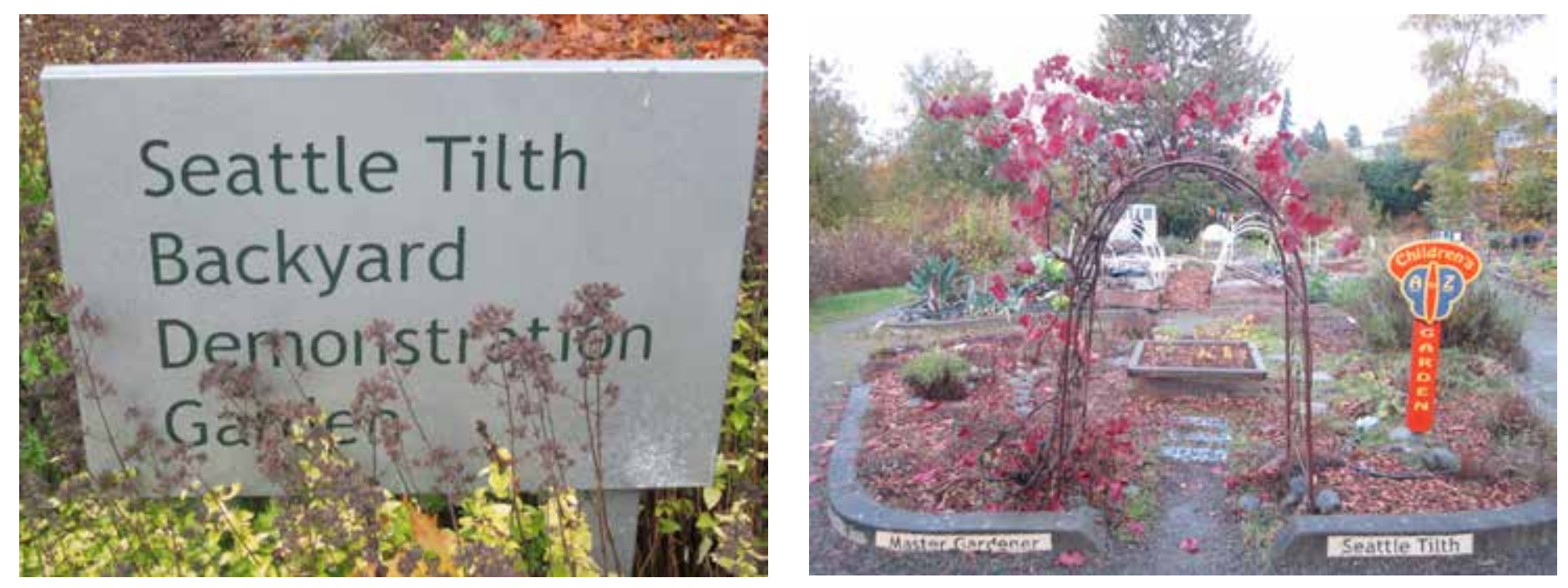
O parque infantil é temático, tendo como equipamento principal, um velho trator e uma série de ferramentas. A quadra é isolada por um alambrado temático, decorado por uma série de ferramentas de jardinagem que chamam a atenção dos pedestres. Atrás da quadra há uma pequena área de compostagem (figura 15).

Como os outros estudos de caso, o Bradner Park foi resultado do ativismo da comunidade. Inicialmente, de 1975 a 1983, o terreno foi utilizado para a construção de edifícios portáteis ligados a uma escola e abrigava o programa de centro de juventude e serviços à família. Em 1987, o programa P-Patch implantou uma horta comunitária para os residentes locais nos espaços livres do terreno. Entretanto, na década de 90 a Prefeitura, a fim de explorar as vistas do terreno, decidiu elaborar estudos para a venda e a implantação de um empreendimento residencial privado. A comunidade se mobilizou e atraiu a atenção de vereadores para a permanência da horta comunitária e para o estabelecimento de um parque na área. Através de um movimento chamado Protect our Parks, o grupo mobilizou comunidades de toda a cidade e coletou cerca de 24.000 assinaturas para que a distribuição de novos parques de vizinhança fosse prioritária e sobrepusesse interesses na venda de terrenos públicos. A Câmara de Vereadores aprovou uma lei que endossou a reivindicação (HOU; JOHNSON; LAWSON, 2009).

O plano desenvolvido por Barker contou com a participação através de tradutores de imigrantes do Laos, residentes na área, e de outros participantes locais e o número de canteiros passou de 39 para 61.

Figura 15: Elementos lúdicos no cercamento do parque infantil. Fotos: Patrícia Akinaga.
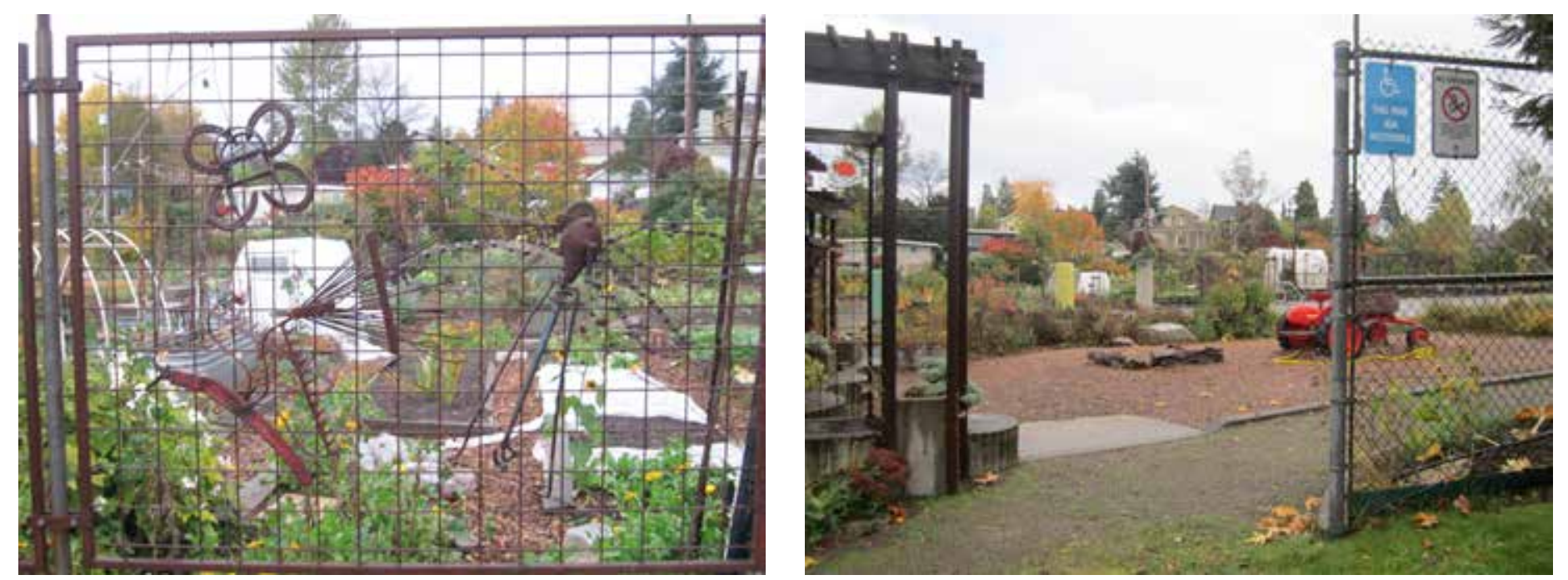
Figura 16:

As práticas sustentáveis estão presentes em placas de sinalização como "usar a água com consciência". Foto: Patrícia Akinaga.
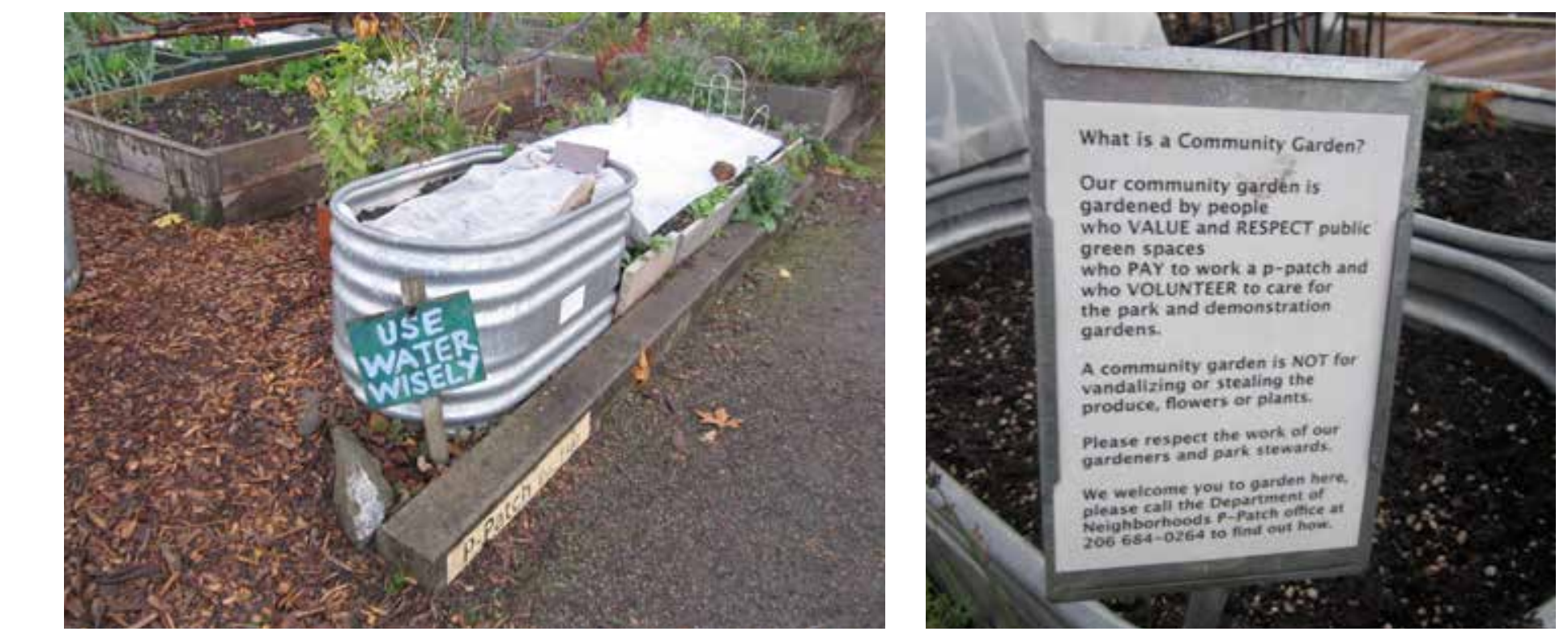

\subsubsection{BELLTOWN P-PATCH}

O jardim comunitário de Belltown fica localizado próximo ao centro da cidade e ocupa um terreno com declividade acentuada. Apesar de pequeno, há uma diversidade de espécies ornamentais e comestíveis. As vistas para o Oceano e a relação com a rua são características que tornam este local especial. A escala é comparável a de um pocket park e o seu contexto urbano de uso misto reforçam este caráter. $\mathrm{O}$ projeto aproveita a declividade da rua e uma "escada cisterna" é projetada na calçada.

O índice pluviométrico de Seattle é alto. No ditado popular, chove na cidade de 01 de Janeiro a 31 de Dezembro. 0 projeto incorpora as águas pluviais no desenho das escadas e dá vida a uma inusitada cascata que corre paralelamente aos degraus.

Outros elementos de arte pública estão distribuídos por todo o jardim e demonstra a participação da comunidade local na colocação de cada elemento. Os canteiros têm sua configuração em platôs e são interligados por um caminho estreito de pedrisco que dá acesso a todos eles e por onde toda a infraestrutura passa, como iluminação e torneiras para irrigação. 
Figura 17:

Entrada das "escadas cisternas" da Vine Street. Foto: Patrícia Akinaga

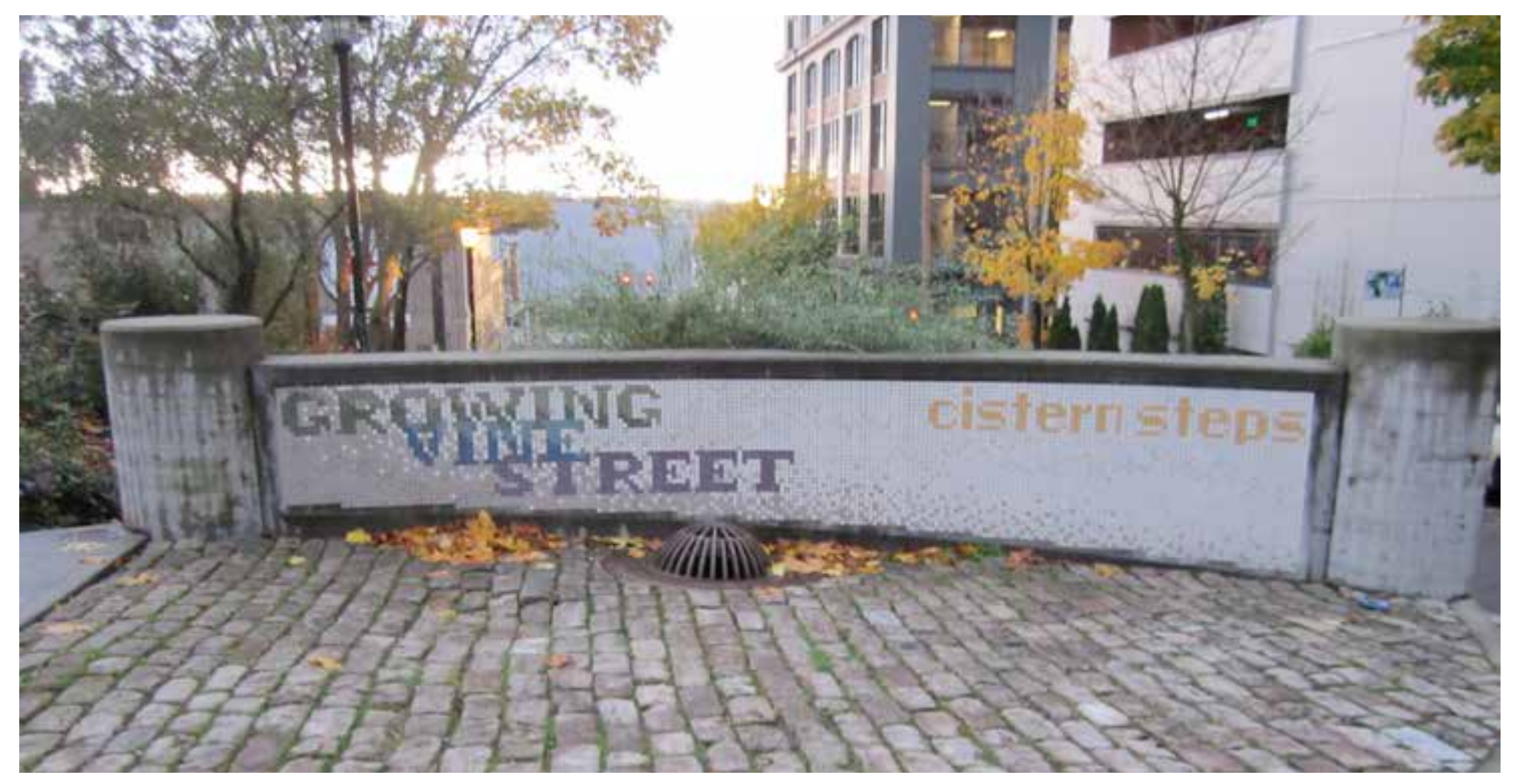

\subsubsection{INTERBAY P-PATCH}

O jardim Interbay P-Patch foi inaugurado em 1974. A gestão é do Programa P-Patch do Departamento de Bairros da Prefeitura de Seattle e da equipe Interbay P-Patch. Localiza-se em uma área distante do centro, parte de um aterro necessário para criar novas áreas de expansão urbana.

Este jardim é diferenciado por estar localizado entre dois bairros: Queen Anne, com 26.595 habitantes e Magnolia, com 21.579 habitantes, e seu acesso principal fica na Avenida 15, uma via arterial que liga o centro da cidade de Seattle e os bairros do norte. Um pomar e uma berma plantada constituem uma zona de amortecimento e até o visitante passar pelo portão, não percebe a imensidão verde e diversa que compõe o jardim (HOU; JOHNSON; LAWSON, 2009).

O projeto foi construído em fases, sendo a primeira e a segunda fase com o projeto do poder público e de voluntários da comunidade do P-Patch, representado pelo arquiteto paisagista da Prefeitura Joe Neiford, e a terceira fase, projetado por voluntários e o escritório CAST. O jardim é gerenciado pela Prefeitura e seu Departamento de Bairros. $O$ terreno pertence ao Departamento 
Figura 18: Sinalização dos caminhos entre canteiros, como parte do sistema de localização e referência wayfinding. Foto: Patrícia Akinaga.

de Parques e Recreação, com cerca de 0,40 hectares e 132 canteiros. Por estar localizado em um aterro coberto por argila, a primeira ação dos participantes foi fazer uma correção do solo com terra orgânica e fertilizantes além da instalação de sistema de irrigação e drenagem.

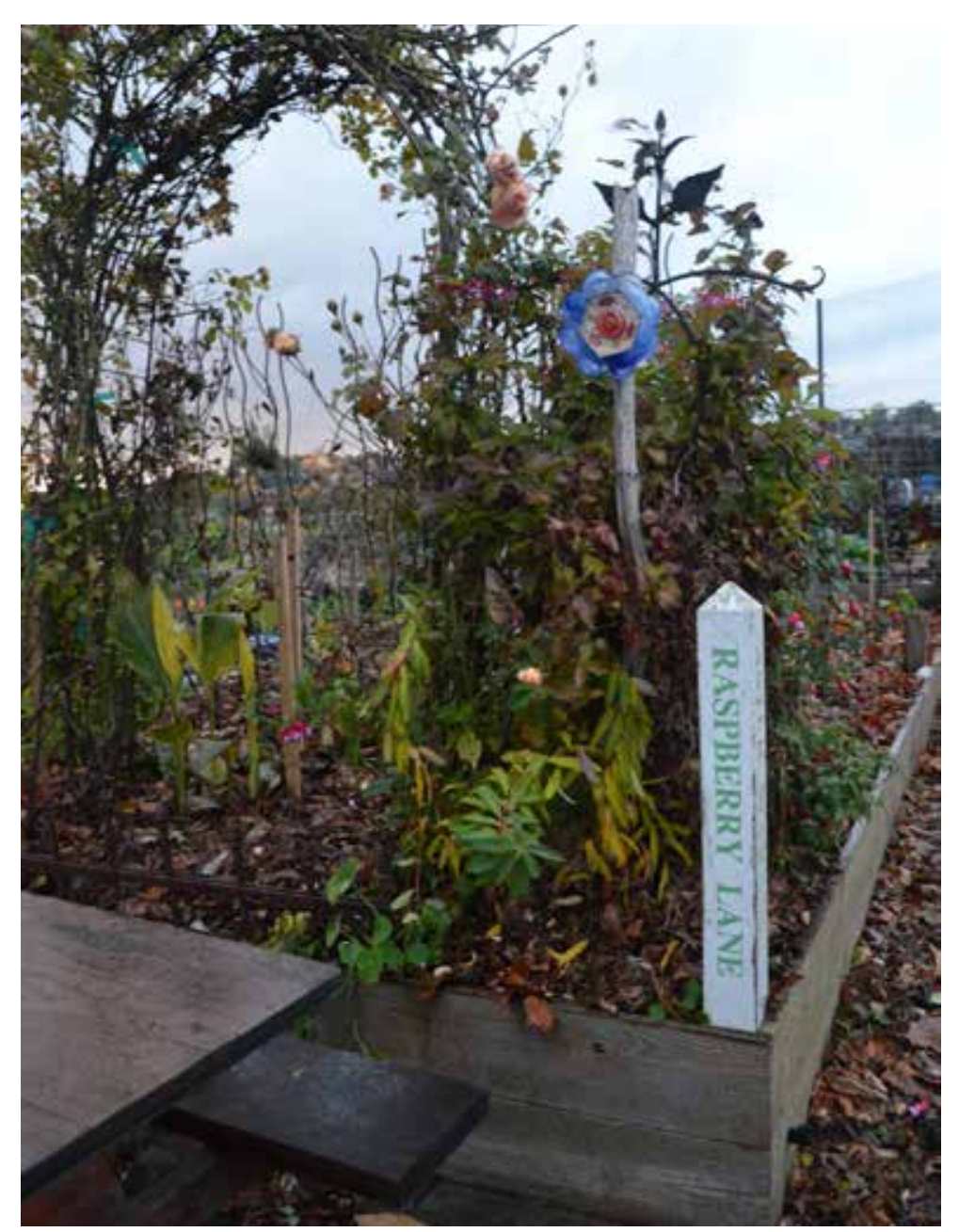

Em 1981, a Prefeitura efetivou seus planos para o estabelecimento de um campo de golfe no local, entretanto, a comunidade local conseguiu junto à Câmara dos Vereadores, a reserva de 4.000 metros quadrados para a manutenção do jardim comunitário. Os canteiros foram “transportados" para uma outra área, onde boa parte está plantada em jardineiras de madeira. Neste mesmo ano, um depósito de ferramentas, uma área para estocar a produção para doação e um espaço para compostagem foram criados e se tornaram elementos permanentes do jardim.

Em 1997, houve uma nova mudança devido à expansão do campo de golfe com o remanejamento de canteiros, mas desta vez a mobilização foi ouvida e os canteiros foram 
melhorados, todos com altura uniforme de cerca de $40 \mathrm{~cm}$ de profundidade, com qualidade do solo excepcional, entremeados por caminhos de 1 metro de largura, configuração que persiste até os dias de hoje (HOU; JOHNSON; LAWSON, 2009).

O local é utilizado para aulas de educação ambiental de escolas da vizinhança e frequentemente são promovidos eventos para socialização e para arrecadação de fundo para melhorias nas estruturas existentes.

O projeto concebido pelo arquiteto senior da Prefeitura Joe Neiford tem o funcionalismo como fio condutor. Nas áreas perimétricas, próximas à avenida arterial 15th, foram alocados o estacionamento, a área de depósito e compostagem. Ao longo de toda esta borda, foram plantadas no talude que separa o jardim da rua, árvores frutíferas em uma área de amortecimento. A propriedade é cercada em toda sua extensão que a divide do campo de golfe e da avenida movimentada que liga os bairros da região norte ao centro de Seattle. Há duas entradas marcadas por uma pérgola e trepadeiras floridas, uma na parte sul mais deserta, junto a um terreno vazio e outra de acesso direto ao estacionamento. Não é cobrada nenhuma taxa de visitação e os portões ficam abertos até o anoitecer.

Na parte sul, os canteiros são longos, retangulares, com 0,5 metros de altura, preenchidos por solo fértil. A configuração é ortogonal, com alamedas em ambos os sentidos de largura regular de um metro. O terreno, praticamente plano, permitiu o projeto de configuração de canteiro de forma bem racional, no sentido leste e oeste os caminhos recebem nome de flores , por exemplo, Tulip Way e no sentido norte e sul, as alamedas têm o nome de frutas como Raspberry Lane, sem qualquer relação direta com o cultivo, onde podemos identificar em sua maioria hortaliças para consumo. Os canteiros são bem mantidos pelos usuários que colocam placas de identificação e o seu toque pessoal com os acabamentos de borda em tijolo ou pequenas cercas decorativas e esculturas (figura 18).

A Avenida 15 é o principal acesso e abriga uma variedade de comércio, desde lojas de equipamentos para casa até pequenos cafés, petshops, lavanderias e farmácias. Sua escala é voltada para o automóvel e não para o pedestre, o que dificulta o uso dos jardins para pessoas não pertencentes ao programa P-Patch. As áreas comuns estão localizadas na parte central onde há uma grande pérgola com uma parreira, mesas com cadeiras, um quiosque com painel de avisos, um pequeno galpão para guarda de ferramentas e os canteiros para acesso de deficientes. A tenda 
Figura 19: Área para eventos no centro do jardim. Foto: Patrícia Akinaga. para doação de alimentos localiza-se próxima ao estacionamento e de fácil acesso pela avenida, resultado de uma imp lantação final, fruto de intenso processo participativo e de desenhos executivos desenvolvidos pela Prefeitura.

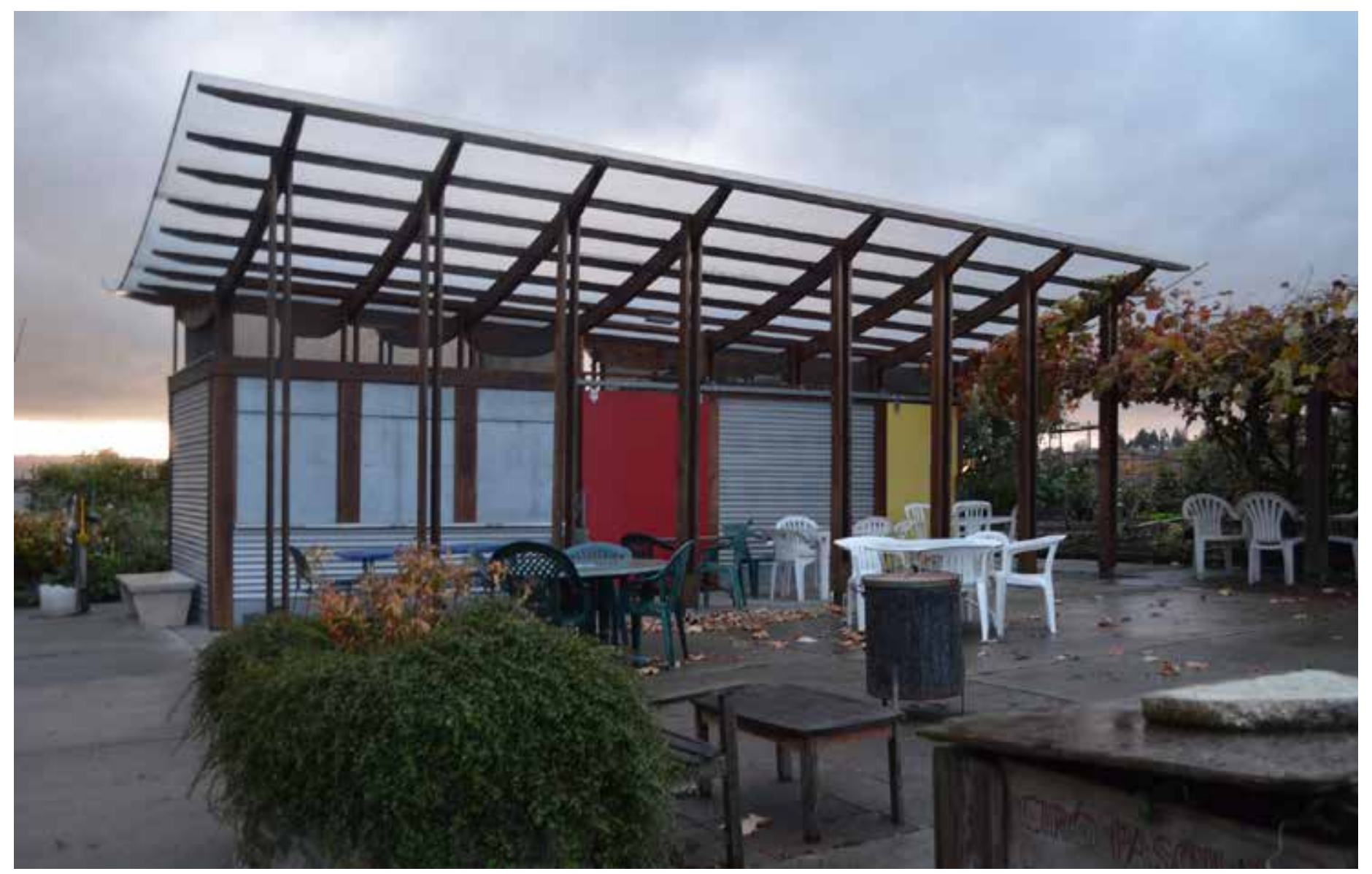

O Interbay P-Patch constitui-se em uma grande massa verde que funciona como área de amortecimento entre a zona residencial de Queen Anne e a zona industrial. A Prefeitura promove eventos sazonais para troca de experiências e fortalecimento do senso de comunidade. A iluminação noturna para estes eventos é produzida localmente por painéis fotovoltaicos que cobrem o galpão e a área de cozinha.

Há também eventos para arrecadação de fundos para manutenção do espaço com venda de flores e mel produzidos localmente. Devido ao seu tamanho e ao fato que alguns usuários não moram perto, o grupo aluga sanitários portáteis localizados próximos ao estacionamento e à estufa. Os materiais usados nas construções são fruto de doações ou compra com desconto e na maioria reciclados coletados por toda a cidade. 
Canteiros de produção com placas com nomes das espécies. Foto: Patrícia Akinaga.
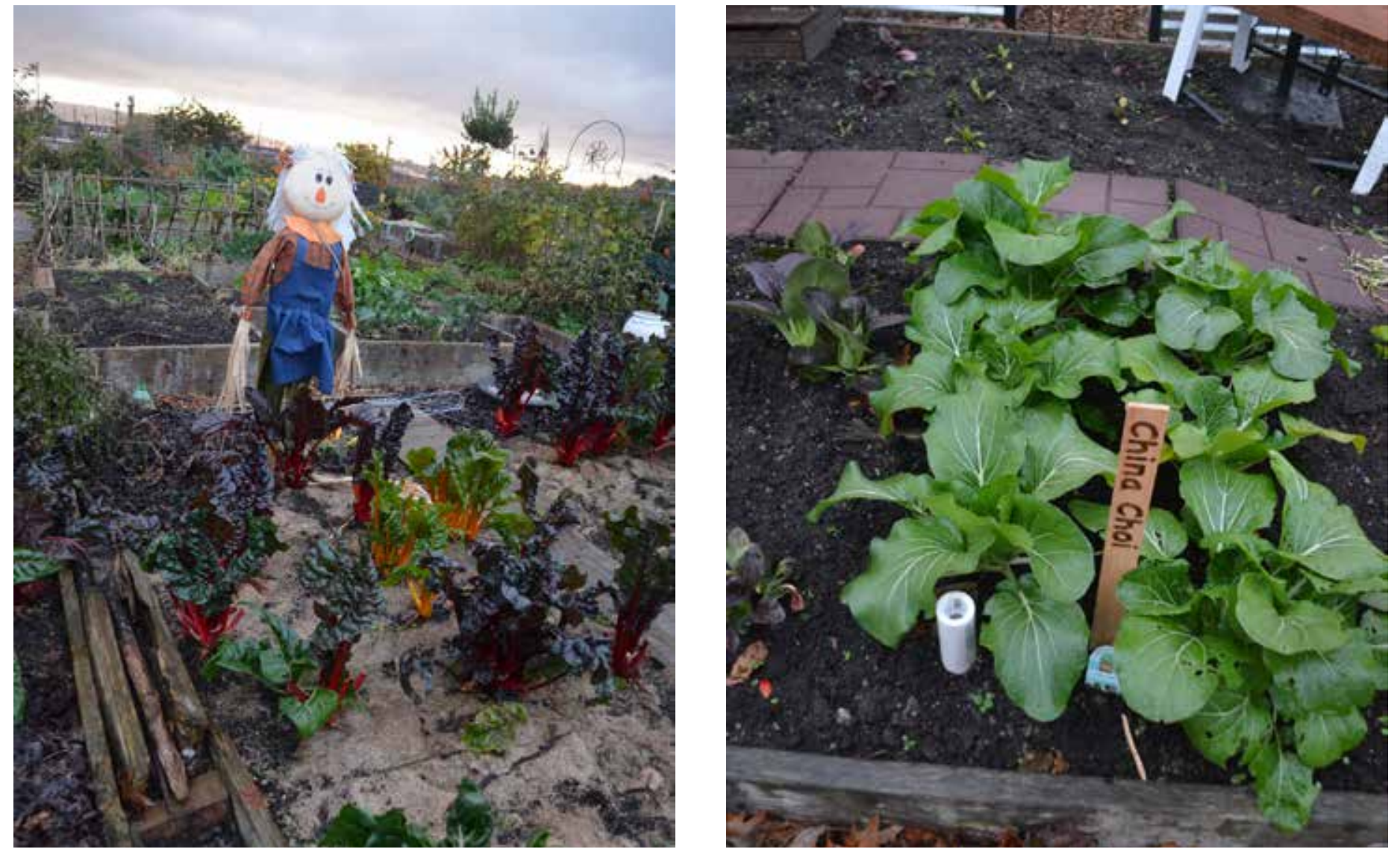

As atividades desenvolvidas no Interbay P-Patch enfatizam o caráter educacional e de interação social como a organização de eventos sociais e educacionais, estímulo à visitação/ turismo, desenvolvimento de programas para compostagem, enriquecimento de solos, além do programa de produção para o banco de alimentos, food bank, uso social dos espaços coletivos como o pomar, os jardins da entrada onde todos se reúnem para fazer manutenção, produção de mel também para arrecadação de fundos.

Nem tudo é positivo. O jardim sofre com roubos e despejo de entulho ilegal devido ao tecido sem uso de seu entorno. Alguns atribuem os roubos a mendigos de um abrigo próximo que vão ao jardim para usar os banheiros. Houve uma tentativa, para solucionar o problema de doar um canteiro para este grupo, mas leva tempo para que a relação seja construída. 
Figura 21: Área de compostagem junto a um dos pontos de irrigação. Foto: Patrícia Akinaga.

Apesar de facilitar o acesso, a avenida é um obstáculo para a área seja incorporada no cotidiano da vizinhança.

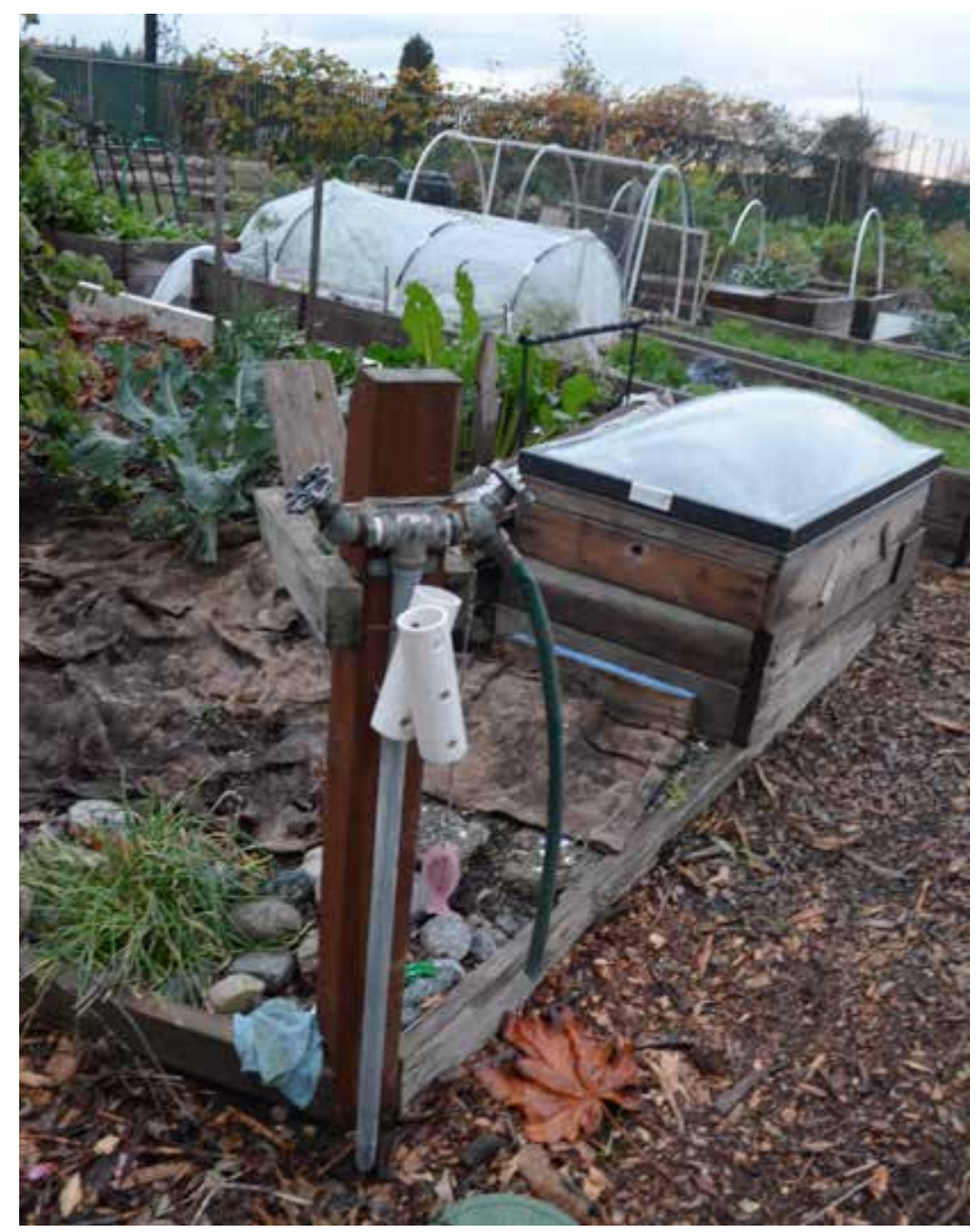

\subsubsection{CASCADE P-PATCH}

Este jardim comunitário fica localizado dentro de um parque com o mesmo nome na área central de Seattle. O terreno pertence ao Departamento de Parques e Recreação da Prefeitura.

Foi inaugurado em 1996 e possui cerca de 57 canteiros em uma área de 780 metros quadrados. Participantes têm que esperar cerca de um ano e meio para conseguir um canteiro. Os canteiros são de $3 \mathrm{~m} \times 3 \mathrm{~m}$ e de $3 \mathrm{~m} \times 4.5 \mathrm{~m}$ e possuem um sistema de coleta das águas pluviais para aproveitamento na sua irrigação (HOU; JOHNSON; LAWSON, 2009). 
Figura 22: Gradil baixo e transparente ao longo de todo perímetro. Foto: Patrícia Akinaga

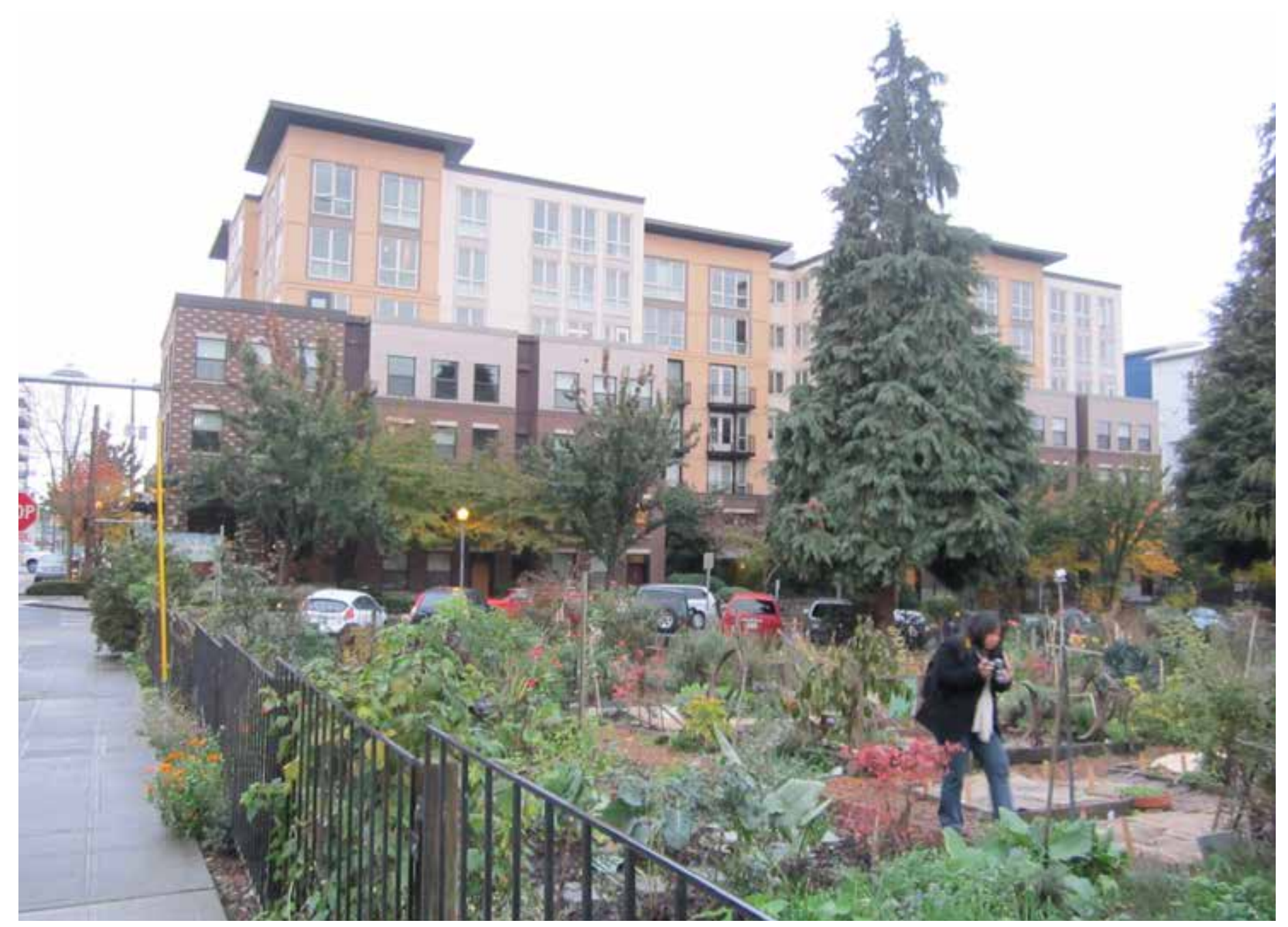

O cercamento baixo, de apenas 1,20 metros, cria um perímetro convidativo ao uso da comunidade, permitindo visualização de todos os espaços do jardim. Grupos escolares e turistas são vistos fotografando, lendo os painéis interpretativos distribuídos nos canteiros (figura 22).

Os edifícios ao redor do parque são de uso misto, sendo o térreo ocupado por pequenos comércios e serviços como padarias, lavanderias e sapatarias. O parque ocupa uma posição de destaque na vizinhança.

Os elementos lúdicos espalhados por todo parque fazem alusão à presença da horta e do jardim comunitário no parque. A área ocupada por eles é separada das demais áreas de lazer do parque através de uma cerca baixa e um portão de acesso, aberto durante suas horas de operação. $O$ parque só é fechado das 23:30 horas às 4:30 horas da manhã. 
Figura 23:

Placa padrão da Prefeitura de Seattle. Foto: Patrícia Akinaga.

Figura 24:

Sinalização para controle de comportamento no parque, placas regulamentadoras. Foto: Patrícia Akinaga.
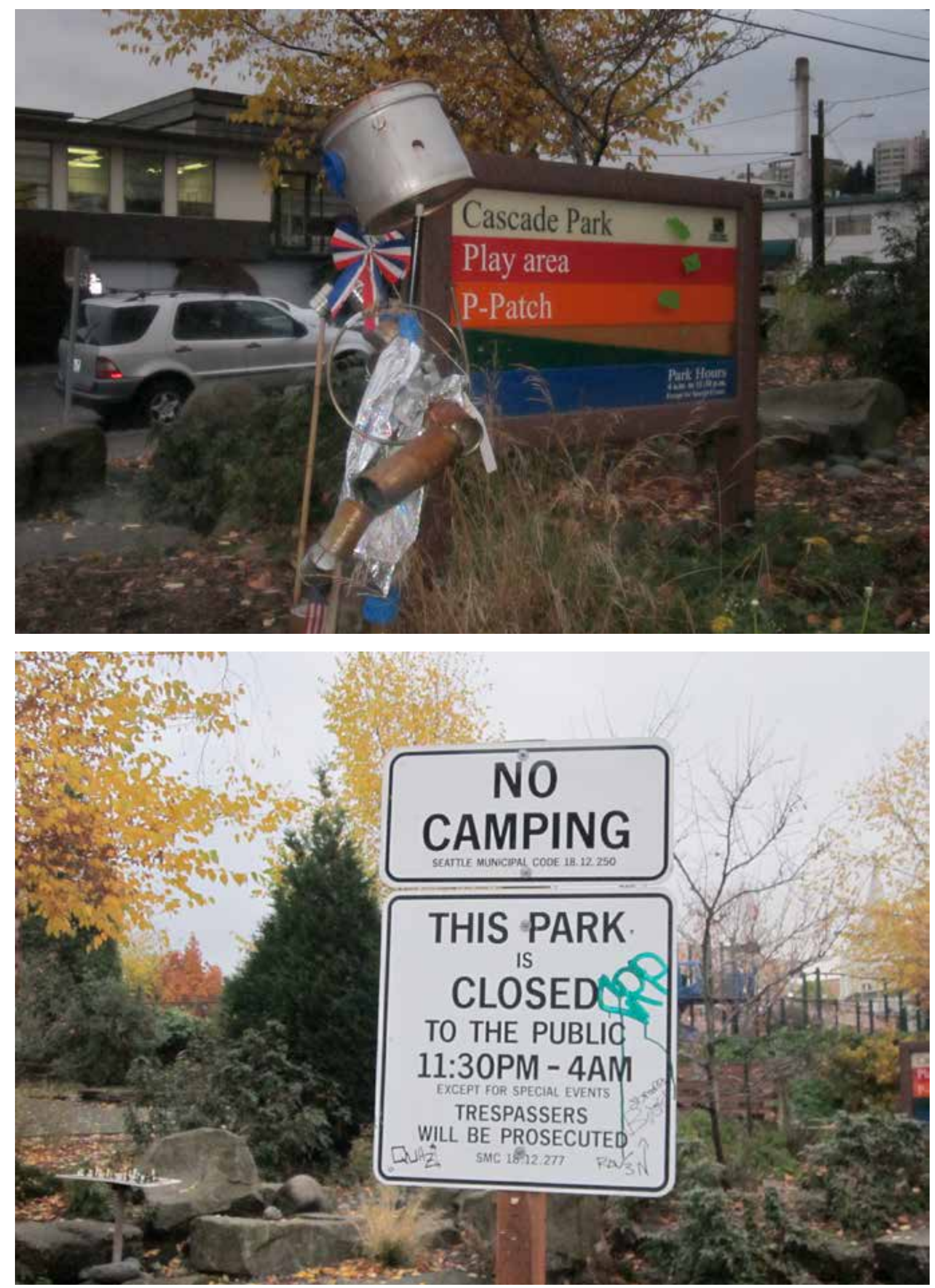

Capítulo 4 - O Conceito da agricultura urbana comunitária como estratégia de infraestrutura verde nos bairros 
Figura 25: As ferramentas de jardinagem estão disponíveis e devidamente identificadas. Foto: Patrícia Akinaga.

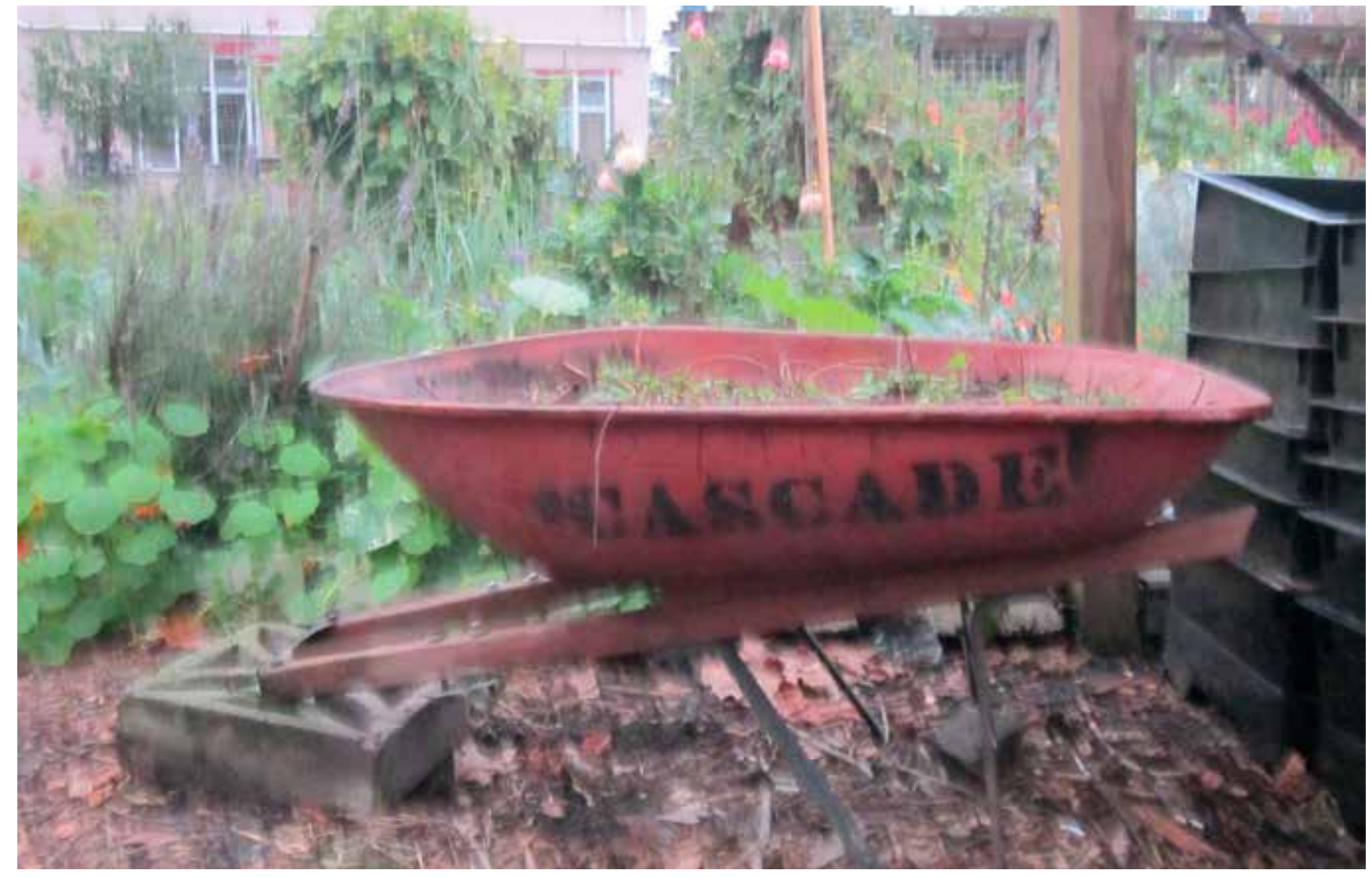

As ferramentas de jardinagem do programa P-Patch são identificadas com o nome do parque e as de maior porte como carrinhos não são guardadas no galpão, ficando próximas aos canteiros de produção, ilustrando a vitalidade do lugar, marcando a presença da comunidade.

As práticas de jardinagem são acompanhadas de diretrizes de sustentabilidade ambiental anotadas em cartazes que indicam o consumo de água, explicam a importância de seu uso racional, inclusive através da motivação de uma competição de quem economiza mais entre todos os jardins P-Patch da cidade.

O local também possui uma área de coleta de águas pluviais do telhado das edificações e uma área de estocagem em tambores. Tubulações são instaladas e chegam até as torneiras próximas dos canteiros. Junto aos tambores é colocada uma série de painéis educativos sobre o ciclo da água. Outra área de tambores é dedicada à compostagem e um grande painel indica o papel das minhocas e os ciclos de produção. 
Figura 26: Local para compostagem com placas de educação ambiental. Foto: Patrícia Akinaga.

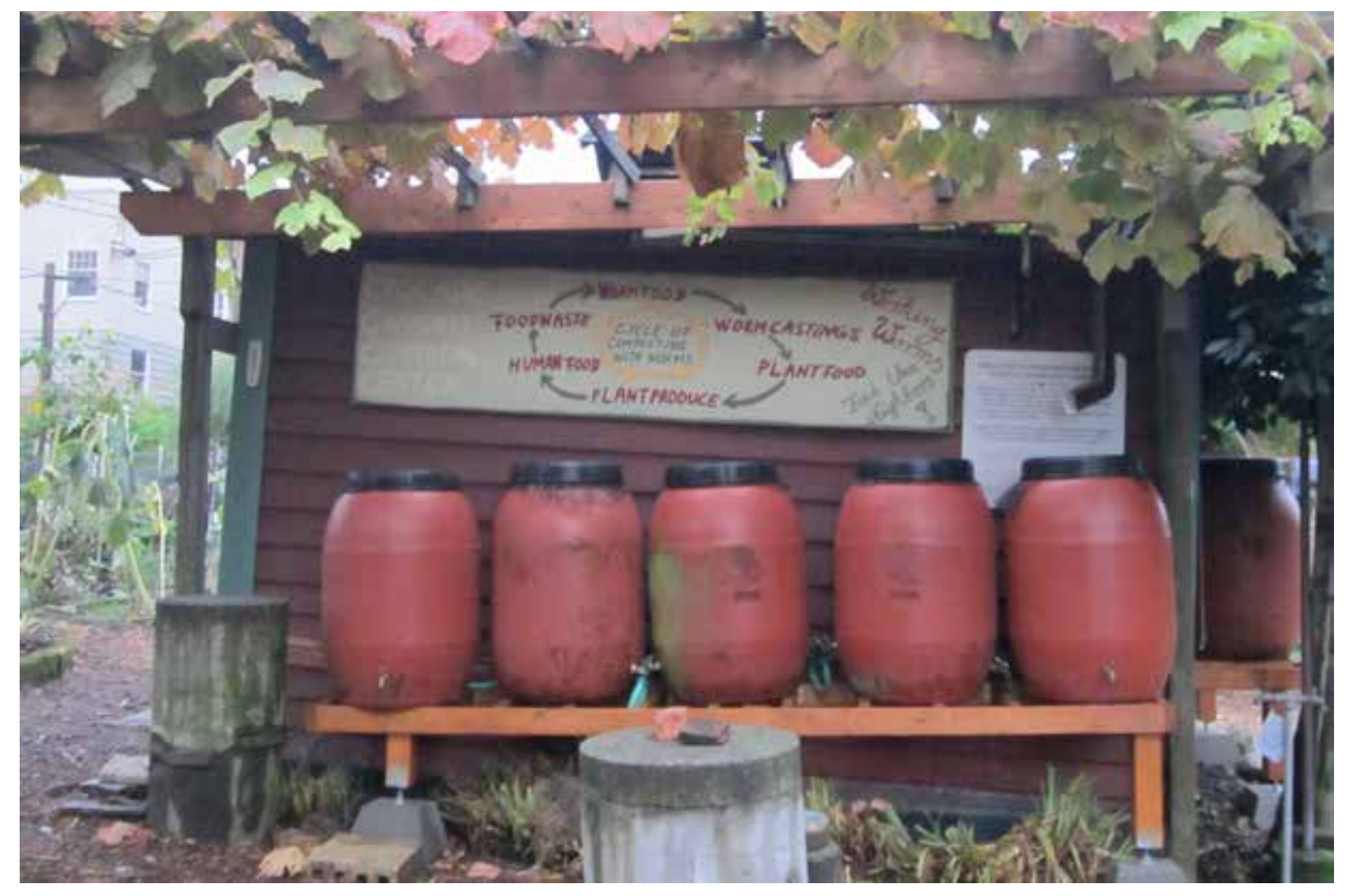

Na entrada há uma placa em diversos idiomas sobre as regras de utilização, não permitindo a colheita por terceiros e com informações caso o visitante queira participar do programa.

Figura 27:

Relatórios e placas regulamentadoras são colocadas próximas a uma das entradas. Foto: Patrícia Akinaga.
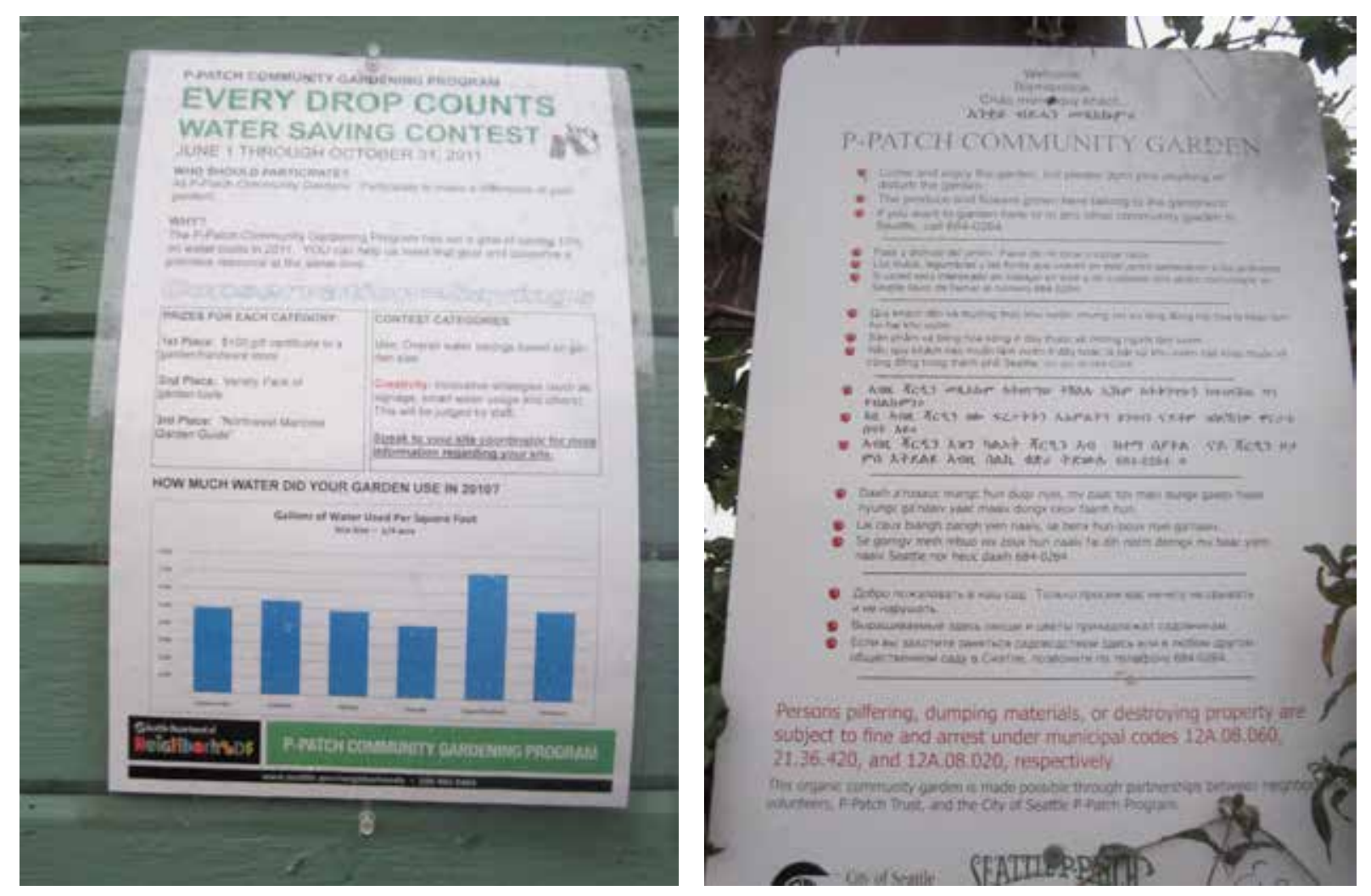
Figura 28: Sacos de juta de embalagem de café brasileiro cobrem os canteiros em fase de germinação. Foto: Patrícia Akinaga.

Os canteiros têm o toque pessoal de cada participante e encontram-se em estágios de produção diversos da semente à muda adulta, pronta para a colheita. As espécies plantadas são bem variadas. Podem ser identificadas verduras, legumes, frutas ou flores para corte.

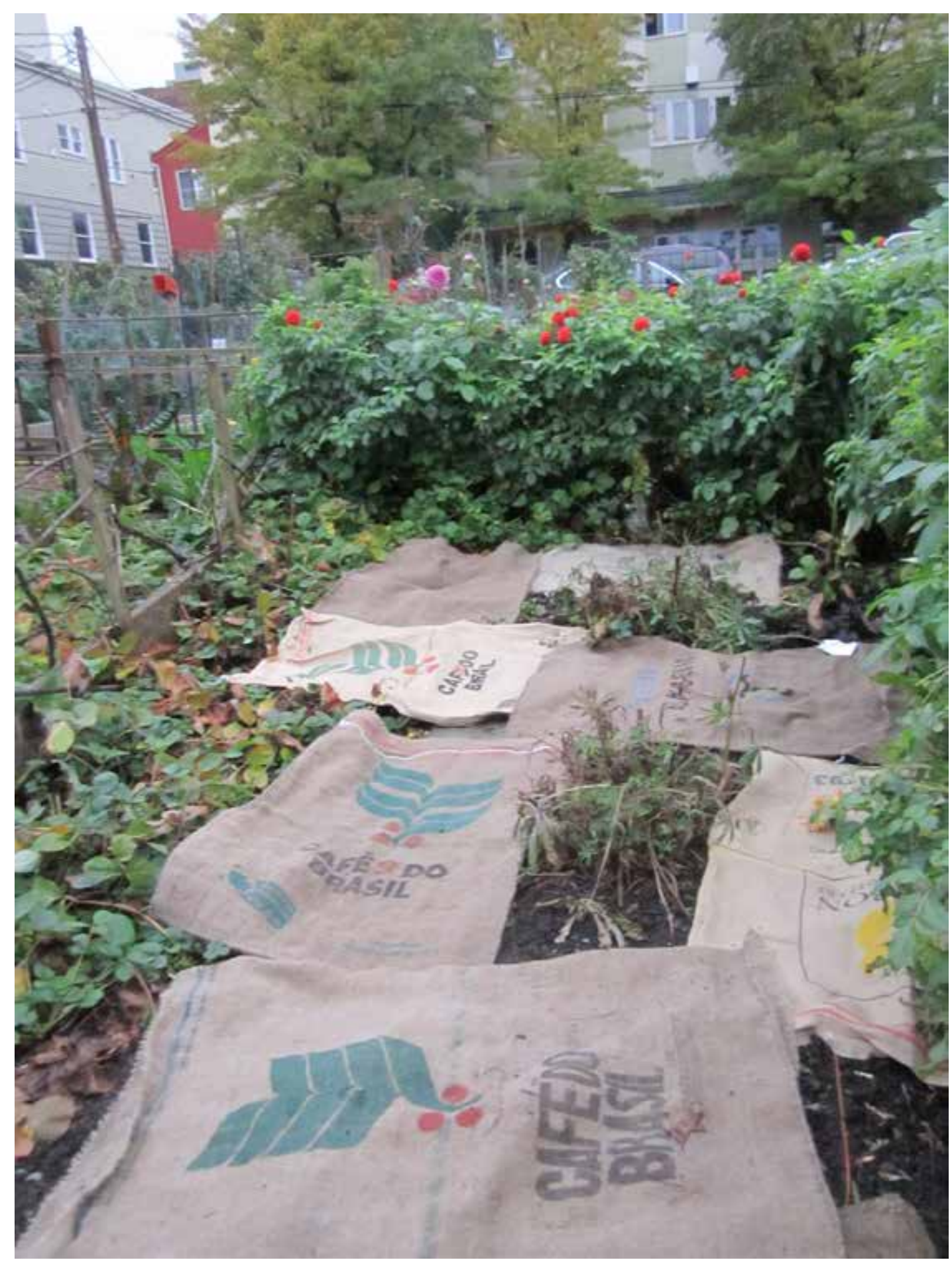


Figura 29:

Os canteiros de produção de legumes e verduras são para

consumo dos participantes

ou para doação. Foto: Patrícia

Akinaga.
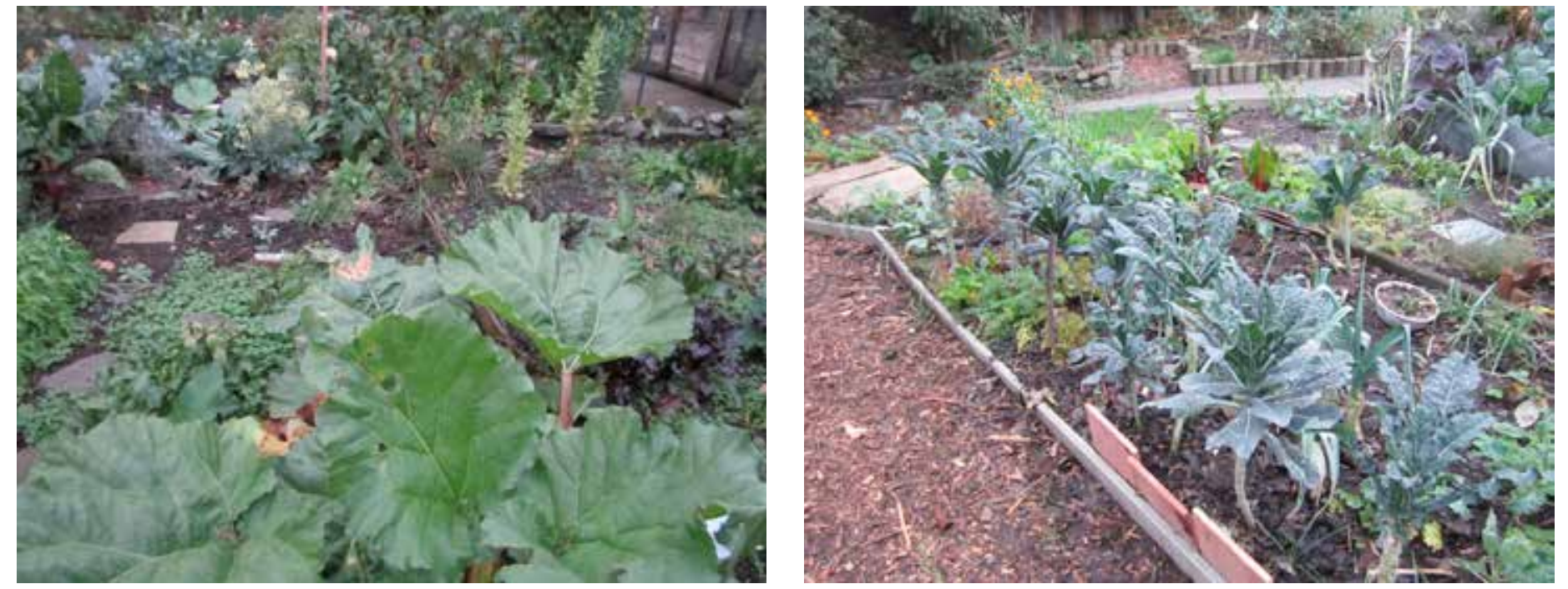

A variedade de cores, texturas e portes criam a riqueza do jardim e mostram a diversidade presente na comunidade, refletida em sua produção.

Figura 30:

A arte pública é uma atração à parte do jardim que atrai turistas. Foto: Patrícia Akinaga.

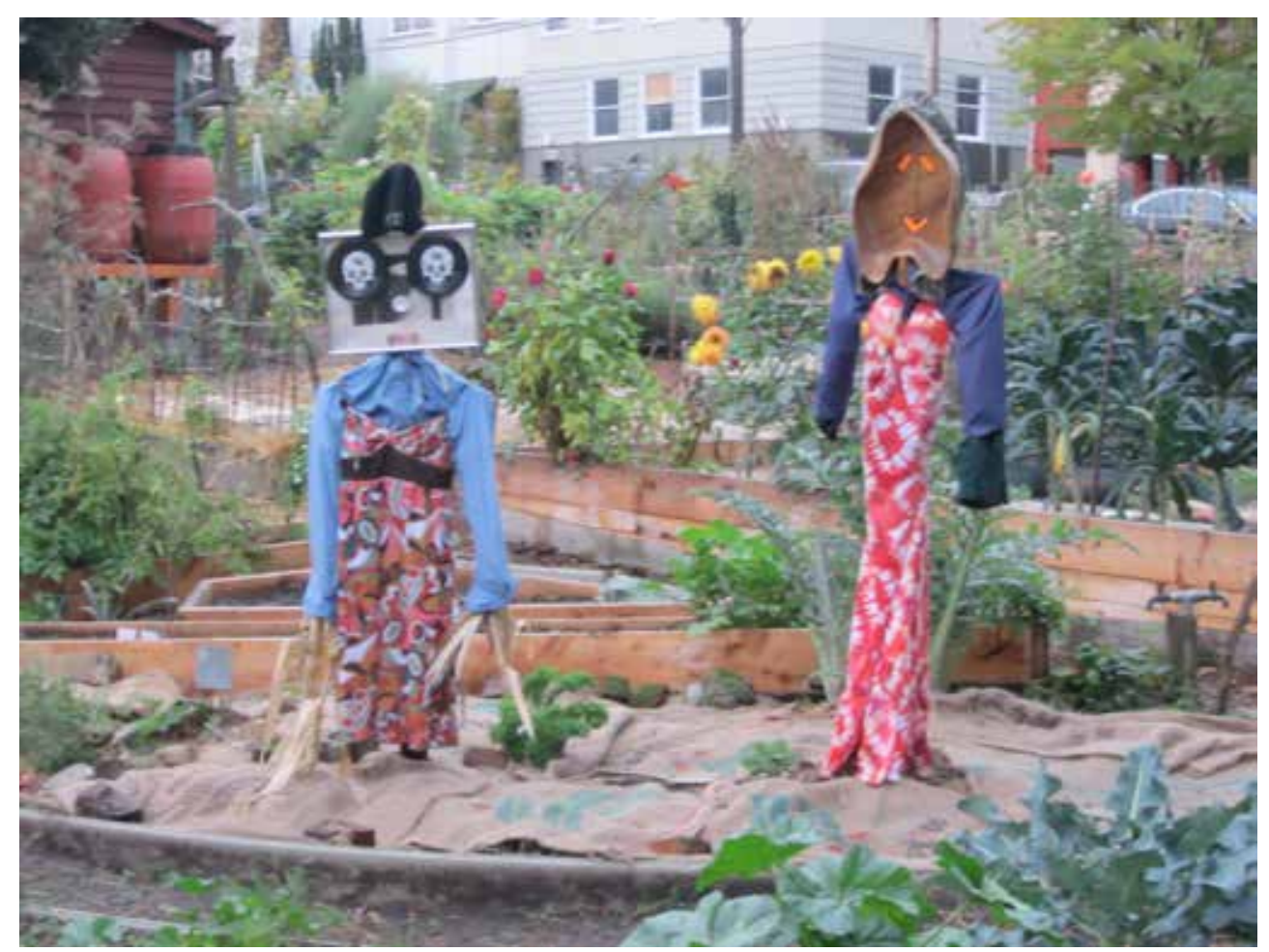

Elementos de arte são uma atração a parte do jardim e ilustram a construção coletiva do espaço. 
Figura 31:

Placas com mensagem dos participantes, parte do programa educativo. Foto: Patrícia Akinaga.

As placas educativas estão distribuídas por todos os canteiros com mensagens como: "Adiciono material de compostagem e cascas de árvore para alimentar meu jardim orgânico e proteger o solo de perder umidade. Isso ajuda o crescimento das raízes e beneficia uma variedade de animais e bactérias sob a camada superficial do meu solo."

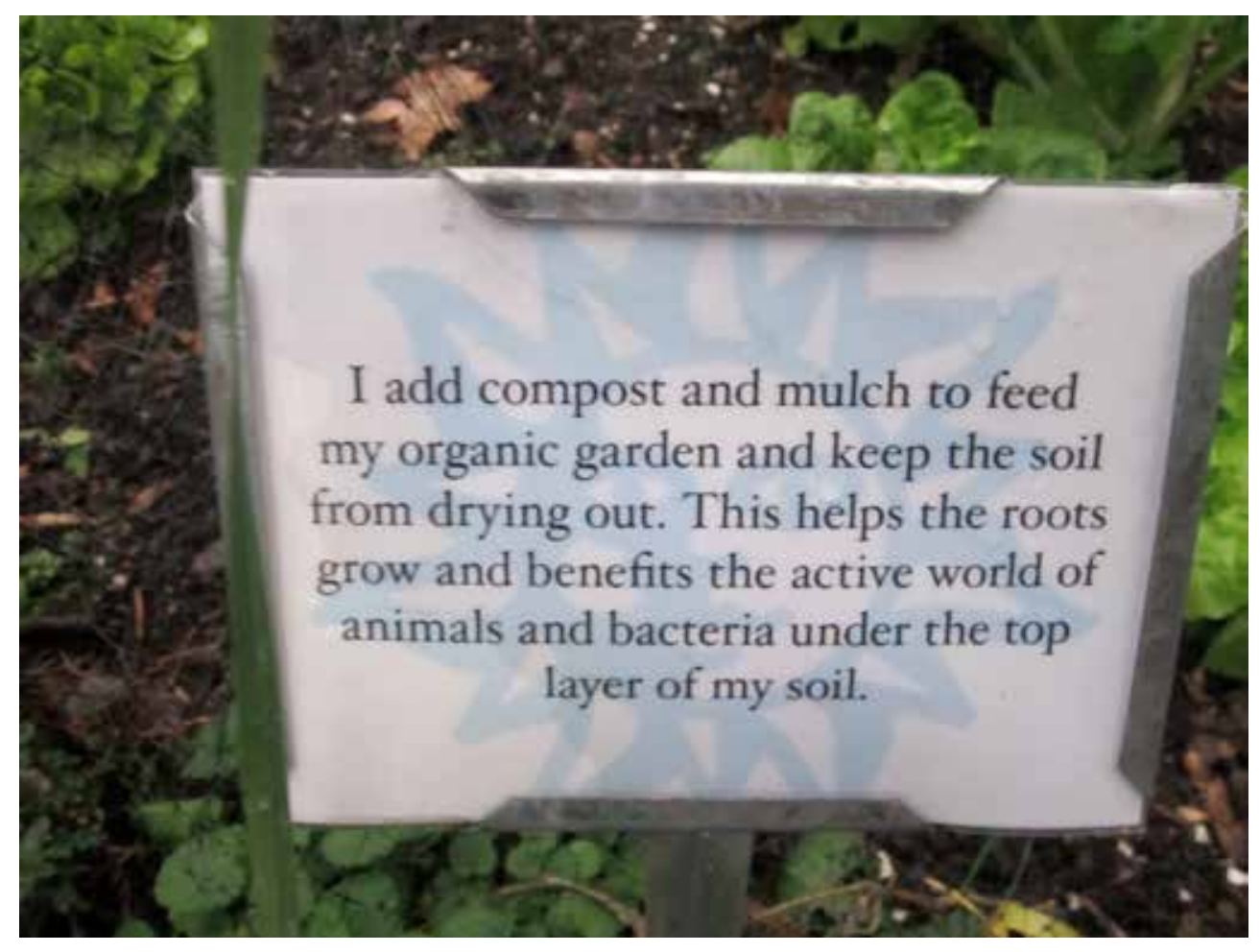

Figura 32: Placa com o telefone do programa para que as pessoas não peguem frutos, flores e verduras. Foto: Patrícia Akinaga.

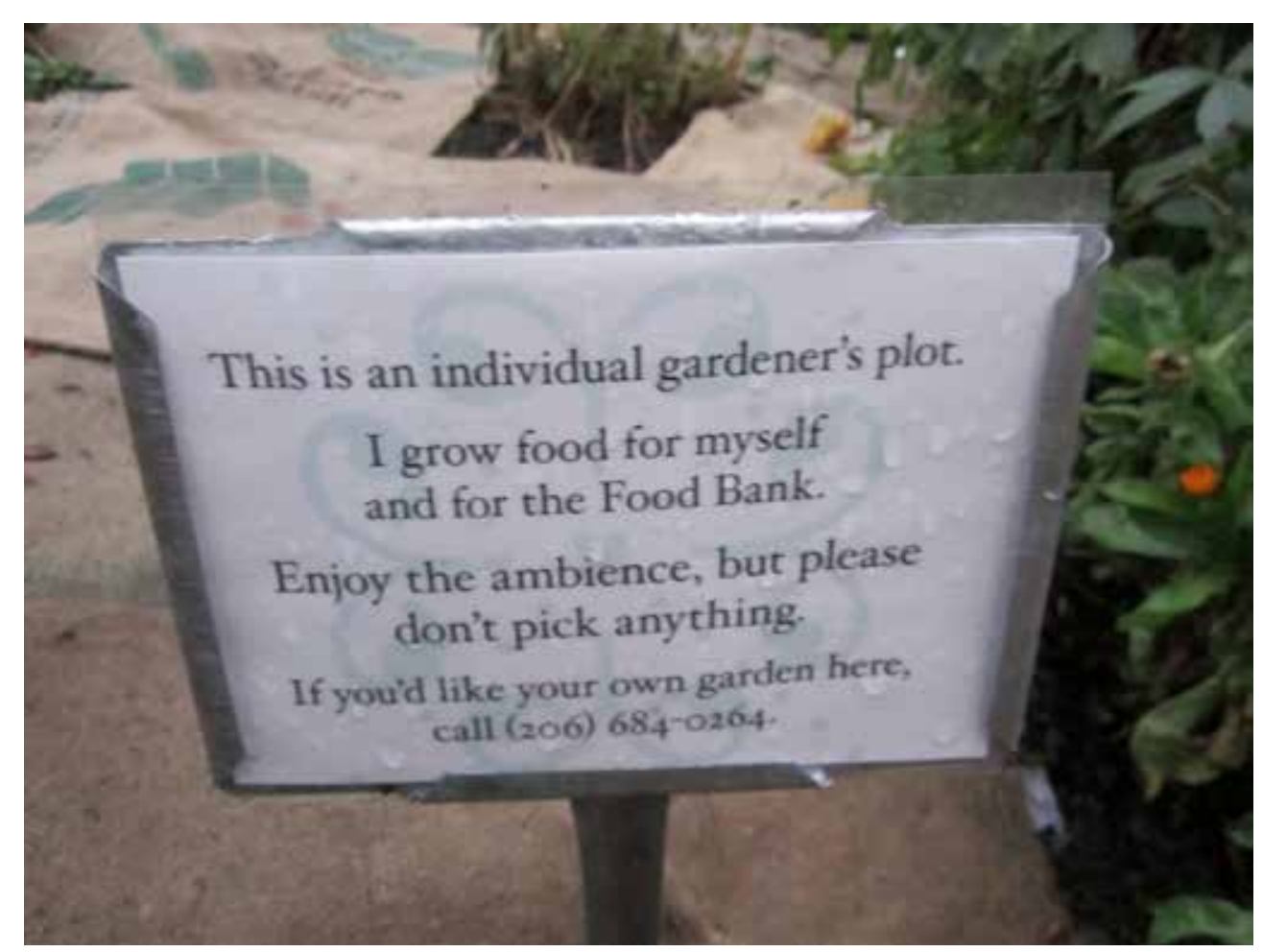




\subsection{CRESCIMENTO DA AGRICULTURA URBANA}

Em 2010, Seattle declarou o ano da Agricultura Urbana. Os estudantes de Arquitetura Paisagística da Universidade deWashington, da Faculdade do Ambiente Construído organizaram uma oficina com a comunidade para explorar ideias de projeto para agricultura urbana.

Muitos países asiáticos produzem mais de $60 \%$ de seus alimentos na cidade. A Prefeitura de Seattle considera rever a sua legislação atual para incorporar cada vez mais a agricultura na cidade e também modificar a lei que proíbe a venda de alimentos produzidos nos quintais.

O professor Parwinder S. Grewal, do Centro para o Ambiente Urbano e Desenvolvimento Econômico (Center for Urban Environment and Economic Development) calculou que se 80\% de cada lote vazio da cidade americana de Cleveland fosse convertido para o uso agrícola seria possível produzir entre $22 \%$ e $44 \%$ do total da demanda da cidade por produtos frescos e cerca de $25 \%$ da demanda por frango e ovos (HOU; JOHNSON; LAWSON, 2009).

Pesquisas como esta se tornam cada vez mais relevantes e derivam da busca de soluções para problemas contemporâneos dos centros urbanos: alimentos a preços mais acessíveis, diminuição da distância entre produção e centros de consumo, o aproveitamento de vazios urbanos, construção de comunidades mais saudáveis e com espírito colaborativo e consequente redução da criminalidade e aumento da conscientização da importância de se preservar as áreas verdes e os recursos naturais.

A presença de jardins comunitários nos bairros tem grande valor ambiental, pois representa um maior número de áreas verdes reduzindo a poluição, servindo de habitat para a fauna local e contribuindo para diminuição de ilhas de calor. Do ponto de vista econômico, há uma redução do consumo de energia, pois a produção local propicia economia no custo de transporte e no armazenamento de produtos. Consumir alimentos produzidos a menos de 160 km resulta em reduções das emissões de carbono proveniente dos automóveis e da indústria de embalagens. Outro aspecto importante está no aproveitamento de águas pluviais para a irrigação e o uso de resíduos orgânicos na fabricação de fertilizantes. 
Tendo como foco o desenvolvimento urbano, o fato de se dar uso a terrenos antes subutilizados na cidade, com a produção de alimentos, é uma estratégia interessante e como nos jardins comunitários de Seattle, pode-se adotar ciclos de produção de curta duração, um ano ou dois para que em alguns casos este uso possa ser uma alternativa até que a área e seu tecido em volta se regenerem e possam ganhar novos usos.

No caso do jardim Interbay, por exemplo, ele se transformou, realocou-se devido a planos da Prefeitura, mas, por fim, remanesceu na área e hoje mais do que uma área de produção, representa uma área verde importante.

No âmbito social, a produção local permite acesso a alimentos frescos a populações de baixa renda, cria empregos, locais de capacitação e constrói o espírito de coletividade. Replicar o modelo, desde o pequeno cultivo nos quintais de residências e escolas, até um plantio em escala de vizinhança, é uma estratégia que conduz a um crescimento urbano mais sustentável e à melhoria da qualidade de vida.

Em 2012, mais de 38\% das residências americanas, representando 41 milhões de pessoas, cultivaram uma horta e colheram seu próprio alimento, o que melhorou sua qualidade e educação das crianças. Outro exemplo é o da cidade de Chicago, que implementou jardins comunitários em seu programa de tetos verdes.

A Prefeitura de Los Angeles criou um sistema chamado Urban Farming Food Chain Project, que consiste na fabricação de painéis de alumínio ou aço para serem fixados nas paredes externas dos edifícios, com espessuras que variam de 3 a 6 polegadas preenchidos de solo orgânico produzidos pela Green Living Technologies. Uma parceria da empresa com o escritório do arquiteto de Nova Iorque Elmslie Osler instalou quatro destes painéis no centro de Los Angeles para alimentar a população de baixa renda e os mendigos.

O escritório local Mia Lehrer + Associates concebeu o projeto Farms on wheels para distribuição de mercadorias de pequenos produtores através de um sistema de furgões de baixa emissão, estrategicamente alocados nas vizinhanças, de acordo com seu perfil de consumo em substituição ao consumo de alimentos nas redes de supermercado para onde as pessoas no geral dirigem seus veículos para comprar produtos provenientes de lugares distantes. 
A Prefeitura de Miami, através do programa Iniciativa de Agricultura Urbana, criou novas leis para regulamentar jardins, como jardins comunitários, tetos verdes, estufas e jardins nos quintais, sendo o objetivo motivar a criação dos mesmos.

Estas ações na escala municipal são alguns exemplos de agricultura urbana e que, se implantadas em uma escala regional, podem garantir um futuro mais sustentável. Cabe aos arquitetos e urbanistas a função de melhor compreender esta tipologia de ocupação do solo urbano como projetistas e organizadores de oficinas na mobilização de comunidades. 


\section{CAPÍTULO 5}

SEATTLE E LOS ANGELES: PROJETOS DE INFRAESTRUTURA VERDE NA ESCALA DO BAIRRO

5.1 PROJETO DAS BACIAS HIDROGRÁFICAS DA CIDADE DE SEATTLE

5.1.1 OS BENEFÍCIOS DO SISTEMA DE DRENAGEM NATURAL (NDS)

5.1.2 O SISTEMA DE DRENAGEM 101 DE SEATTLE

5.1.3 O PROJETO PILOTO SEA STREET

5.1.4 A REQUALIFICAÇÃO DO BAIRRO HIGH POINT

5.1.4.1 BENEFÍCIOS

5.1.4.2 CRONOGRAMA DE IMPLANTAÇÃO

5.2 RUA CASCADE E A RUA NOROESTE 110

5.3 A MALHA VERDE BROADVIEW

5.4 A MALHA VERDE DE PINEHURST

5.5 DESAFIO

5.6 O CASO DO PROJETO PIGGYBACK YARD EM LOS ANGELES, CALIFÓRNIA 


\subsection{PROJETOS DAS BACIAS HIDROGRÁFICAS DA CIDADE DE SEATTLE}

Cerca de um terço da cidade de Seattle não possui rede de captação e tratamento de águas pluviais. Nestes lugares, as águas percorrem o meio fio, se acumulam no final das quadras poluídas por óleo das pistas, pesticidas dos gramados e por fim deságuam em lagos e cursos d'água gerando um grave problema ambiental em Puget Sound e o Lago Washington.

Com o aumento da consciência ambiental, a comunidade se mobilizou e pressionou a Prefeitura por soluções, pois os problemas como o assoreamento de riachos começaram a afetar a reprodução do salmão e a mata ciliar. Uma solução tradicional de captação de águas pluviais poderia resolver o problema com as enchentes, mas ao mesmo tempo desaguaria um volume grande de águas poluídas nos lagos e cursos d'água locais, além de consumir um alto investimento, recursos indisponíveis para a cidade de Seattle.

A solução veio com a criação de um tipo diferente de bairro, com ruas onde canteiros pudessem funcionar como biovaletas e substituir sarjetas e bocas de lobo na captação da água, permitindo sua percolação gradativa e filtração através de espécies vegetais, de forma a reduzir as águas superficiais a quase zero, com exceção da vazão provocada por chuvas mais intensas. O projeto piloto foi chamado de SEA Street, Street Edge Alternatives, alternativas para condições de borda da rua, com aplicação de uma série de técnicas de baixo impacto. A primeira SEA Street foi implantada em Seattle em 2001.

\subsubsection{OS BENEFÍCIOS DO SISTEMA DE DRENAGEM NATURAL (NDS)}

Dentre os benefícios oferecidos à comunidade pela implantação do sistema de drenagem natural (NDS) do qual fazem parte as ruas "SEA Streets" podem ser citados:

- Controle da drenagem através do desenho de ruas mais estreitas que reduzem a quantidade de superfícies impermeáveis e criam mais espaço para canteiros, jardins de chuva, que temporariamente retêm e absorvem a água da chuva; 
- Melhoria da qualidade da água através da biofiltração, promovida por plantas e solos nas biovaletas, que removem poluentes provenientes da lavagem de ruas e áreas de estacionamento;

- Projetos de arquitetura paisagística, plantio de calçadas, embelezamento e incremento de valor aos bairros através implantação das áreas verdes;

- Redução da velocidade de tráfego devido à arborização e à redução das áreas pavimentadas, traçados mais curvilíneos que ainda permitem o acesso de veículos de emergência;

- Aumento da interação dentro das comunidades em virtude da colaboração para manutenção dos jardins, da proteção da bacia hidrográfica e a relação cordial dos pedestres nas novas calçadas e ruas;

- Programas de educação ambiental através de exemplos dentro da própria comunidade de como reduzir o problema com as águas pluviais e melhorar a qualidade da água com estratégias inovadoras.

Figura 33: Exemplo de SEA Street em Seattle (2nd Ave.). Foto: Priscilla Tiba. 
A Prefeitura de Seattle tem trabalhado em projetos para o gerenciamento de águas pluviais a fim de recuperar sua qualidade dos cursos d'água e lagos que permeiam toda a cidade. O projeto denominado "Restore our Waters", Recupere nossas Águas, da Secretaria de Infraestrutura, SPU (Seattle Public Utilities) conta com 23 áreas urbanas, de diferentes escalas. Através da diminuição da velocidade de fluxo e filtração das águas de superfície chamadas de runoff, e a recuperação do habitat, a Prefeitura criou uma verdadeira rede de infraestrutura verde e porque não chamar infraestrutura verde e azul, tendo obtido resultados positivos. 0 projeto, mais amplo, incorpora as SEA Streets e consiste na implantação de jardins de chuva, rain gardens, em vias públicas, praças e parques.

A cidade de Seattle possui oito bacias hidrográficas descritas a seguir (figura 34).

O Rio Duwamish é o maior rio de Seattle. Origina-se nas montanhas Cascade e flui pelo Condado de King até atingir a Baía de Elliott. Nas suas margens, o uso do solo é predominantemente industrial, no entanto, o rio é um importante habitat para salmões e trutas, protegido pela comunidade e pelo governo que mantém dois parques principais, o Herring House Park e o South Park Duwamish Waterway Park.

A maior bacia de Seattle é a do Riacho Thornton e é também a mais desenvolvida. O lago de Meadowbrook recebeu melhoramentos em seu habitat e oferece atrações para a comunidade, gerencia e controla aproximadamente vinte e dois milhões de litros na prevenção de enchentes, cria alagados e habitat para uma diversidade de espécies de peixes e aves migratórias.

A segunda maior bacia é a do Riacho Longfellow. Possui uma série de trilhas no vale Delridge, parques e propriedades privadas onde as áreas verdes são conservadas por voluntários com a proteção de coiotes, raposas e outros animais. A terceira bacia é a do Riacho Piper, onde se localiza o parque Carkeek, local onde o salmão retorna todo ano e onde foi implantado um projeto SEA Street Natural Drainage System, o sistema de drenagem natural na via pública ilustrado neste capítulo como estudo de caso. 
Figura 34:

Mapa que ilustra as bacias hidrograficas de Seattle.

Disponivel em: <http:// www.ci.seattle.wa.us/util/ naturalsystems/>. Acesso em: 20 de Setembro de 2011.

\section{Seattle Watershed Projects}

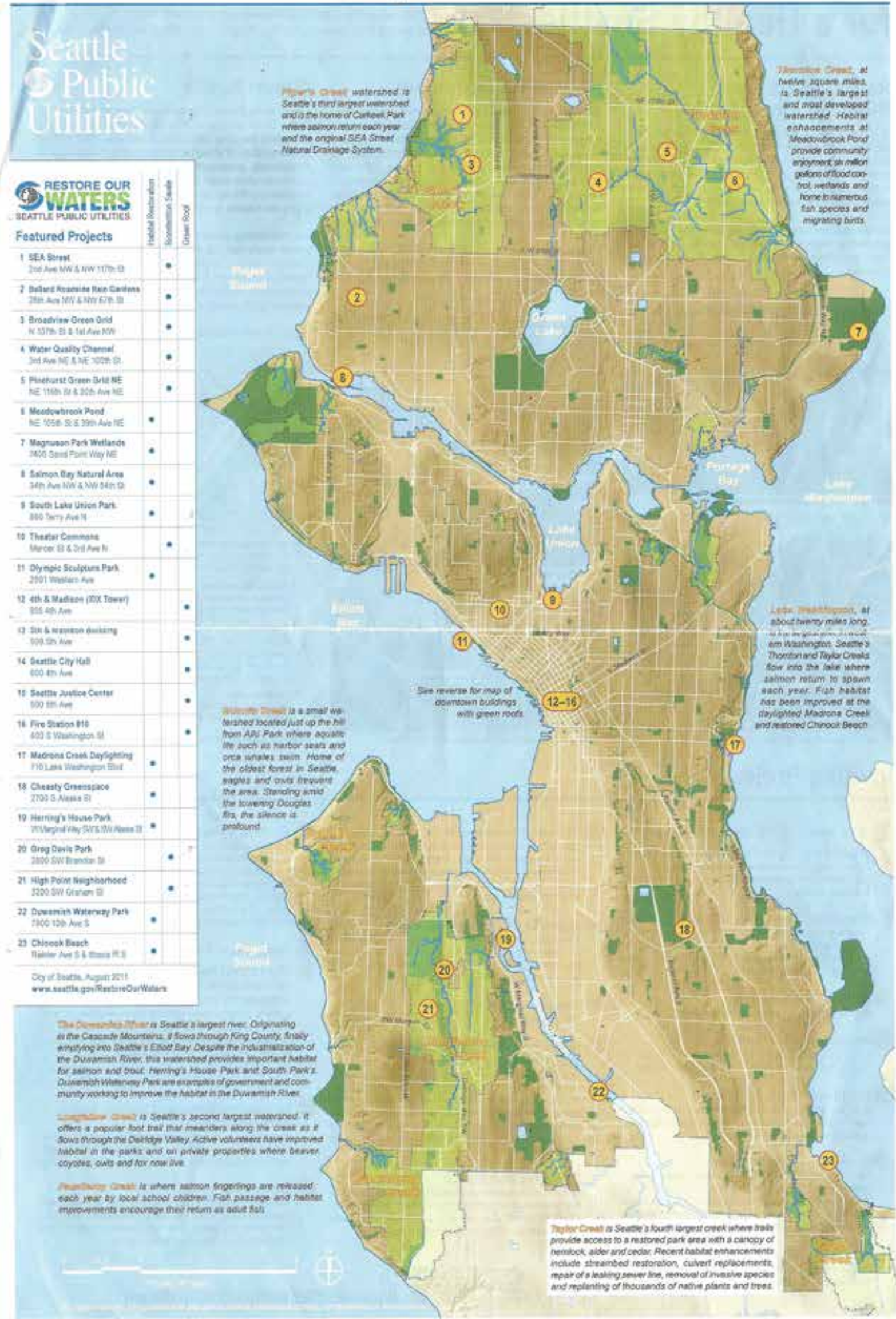


A quarta bacia é a do riacho Taylor com uma série de trilhas que oferecem acesso para um parque recuperado com diversas espécies de árvores. Entre as melhorias implantadas, são destacadas a recuperação do leito do riacho, a substituição do sistema de drenagem, a remoção de espécies invasivas e o replantio de centenas de espécies nativas e árvores.

O riacho Schmitz possui uma bacia pequena, localizada próxima do Parque Aiki, onde a vida selvagem aquática como leões marinhos e baleias orcas domina a paisagem. É onde se localiza também uma das florestas mais antigas de Seattle, com a presença de espécies como águias e corujas. Outro riacho, o Fauntleroy serve de passagem para peixes e a recuperação do habitat os estimula a retornar na vida adulta.

\subsubsection{O SISTEMA DE DRENAGEM 101 DE SEATTLE}

Atualmente a cidade de Seattle possui três tipos distintos de sistema de águas pluviais, cada um cobrindo cerca de um terço da área urbana, de acordo com técnicas e recursos disponíveis na época de implantação dos bairros e durante seu desenvolvimento.

A área mais antiga é constituída do centro e dos bairros e de seu entorno e é atendida por uma rede de esgoto que faz a coleta de escritórios e residências, e quando chove também acumula as águas pluviais de ruas e telhados, ou seja, não há separação. As águas passam pela estação de tratamento de esgoto antes de ser despejadas no oceano em Puget Sound.

Durante as chuvas mais intensas, o sistema se sobrecarrega e, para evitar enchentes ou refluxo, a água é rapidamente encaminhada para o oceano sem nenhum tratamento ou para o Lago Washington. A solução encontrada para minimizar o problema e para atendimento de normas nacionais foi a criação de tubulações mais largas e cisternas subterrâneas para retenção das águas.

A segunda área inclui os bairros fora da área central, mas que já faziam parte da cidade antes de 1950. Nestes bairros, foram construídas novas tubulações para condução do esgoto, direto para as estações de tratamento e novos ramais independentes para o sistema de águas pluviais. 
No entanto, as águas pluviais não são tratadas e são diretamente despejadas no lago Washington e Puget Sound e as águas coletadas em telhados de muitas residências e edifícios comerciais são misturadas ao esgoto. A Secretaria de Infraestrutura de Seattle (SPU), atualmente estuda a possibilidade de implantar nestas áreas o sistema de drenagem natural de baixo impacto, apesar da dificuldade em se obter espaços livres para esta finalidade. Pensase em pequenas áreas de calçada e novas técnicas nas propriedades privadas.

O terceiro sistema de drenagem está implantado no lado norte de Seattle, também anexado na década de 50. O esgoto é tratado, mas não há captação de águas pluviais na maioria das áreas residenciais. As águas correm pelas ruas até encontrar grelhas e são conduzidas diretamente para os lagos e Puget Sound ou para alguns córregos, poluídas pelo material carreado das ruas e nocivas aos peixes e pequenas criaturas integrantes do ciclo alimentar, além de destruir a mata ciliar. Esta área norte recebeu o primeiro projeto piloto do sistema de drenagem natural SEA Street.

\subsubsection{O PROJETO PILOTO SEA STREET}

Os engenheiros e planejadores da Secretaria de Infraestrutura de Seattle SPU, tinham como objetivo criar um sistema inovador que reproduzisse a desempenho do sistema de drenagem natural, antes da ocupação urbana, em meio a capins e árvores onde a água da chuva percolava o solo, com pouco volume de água superficial, alimentando o lençol freático, aquíferos e gradativamente chegando aos cursos d'água. Nestas condições, o nível dos córregos se mantém constante e perfeito para os peixes.

Nas áreas urbanizadas, devido à impermeabilização dos solos, as águas correm em grande velocidade, causando problemas, tais como: o assoreamento de cursos d'água, a poluição e o baixo desempenho na recarga de águas subterrâneas; além disso, o baixo nível das águas prejudica os peixes no Verão.

O objetivo do projeto foi atingir metas superiores às que as leis impunham aos empreendedores. Até então, a Prefeitura os obrigava a reduzir, mas não eliminar as águas pluviais de superfície para uma chuva de período de retorno de dois anos, com tempestade de 
24 horas com a precipitação equivalente a 4,3 cm, em 24 horas e para uma chuva de período de retorno de 25 anos, com a precipitação de $8 \mathrm{~cm}$ em 24 horas.

No final dos anos 90, como parte do Projeto Millenium, do Legado dos Riachos Urbanos, Urban Creeks Legacy Millennium Project, projetos de recuperação entraram em fase de execução em quatro córregos da cidade, como parte do sistema de drenagem. Entre os quatro estão: Piper Creek, Thornton Creek, Taylor Creek e Longfellow Creek. Foi decidido que o Piper Creek apresentava a melhor localização para o projeto piloto, porque sua bacia drenava grandes áreas dos bairros de Broadview e Greenwood, através do Parque Carkeek até Puget Sound.

A comunidade foi fundamental para a implantação do projeto. Um grupo local chamado Carkeek Watershed Community Action Project, é um dos mais ativos em promover a recuperação de cursos d'água e habitat do salmão e havia elaborado um plano de ação para a bacia. Funcionários da Secretaria, através de consultas públicas apresentaram à população os desenhos das ruas com as biovaletas de drenagem e plantio nos dois lados, áreas onde temporariamente a água poderia se acumular, em pequenas lagoas durante as chuvas mais intensas até serem absorvidas vagarosamente pelo solo.

Durante o estudo preliminar, foram identificadas mais de vinte quatro quadras que poderiam receber as obras de melhoria, de acordo com critérios como a declividade.

Através de uma petição assinada por todos os residentes das quadras selecionadas, estes poderiam exprimir o desenho de prosseguir com o projeto. Aliadas à vontade dos residentes, as características específicas da quadra determinaram a escolha da rua mais adequada para receber o projeto. Nenhum custo de implantação do sistema foi repassado aos proprietários. A rua escolhida foi a localizada entre as ruas NW 117th e as ruas NW 120th, na avenida Second Ave.

Após a escolha deu-se início ao processo participativo de projeto, através de uma série de reuniões entre funcionários da Prefeitura e proprietários. Uma das preocupações era a manutenção do número de vagas de estacionamento, com a redução da largura da rua e o 
Figura 35: Biovaleta na 2nd Ave. Foto: Priscilla Tiba

Figura 36:

Second Ave depois da implantação do projeto. Figura extraída do Natural

Drainage System booklet, elaborado pela Secretaria de Infraestrutura de Seattle (SPU)

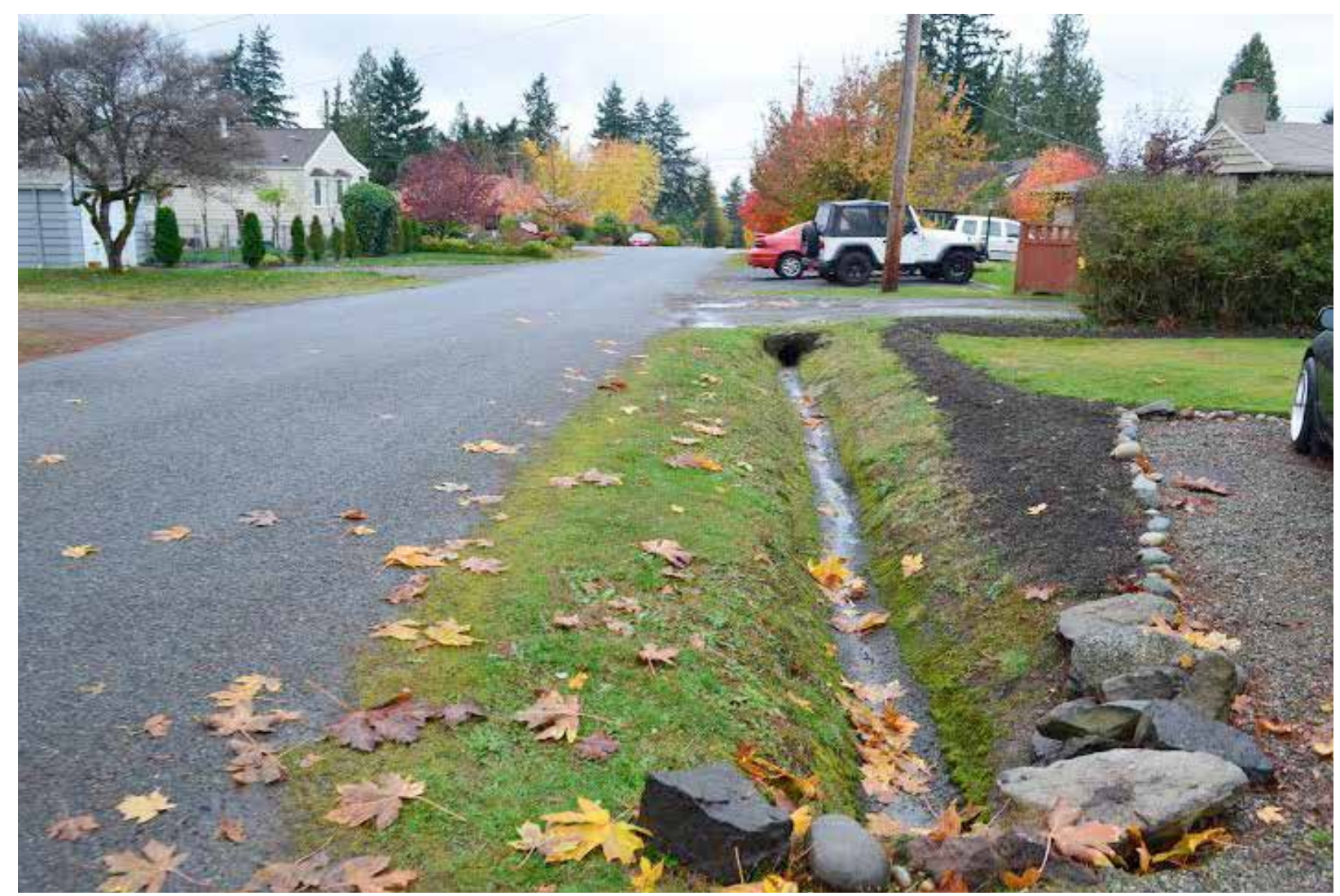

aumento da calçada. Outro aspecto importante foi a de envolver os residentes na manutenção das áreas plantadas, com cerca de 100 árvores novas, perenes e 1.100 arbustos ao longo das biovaletas. Grande parte do sucesso do projeto se deveu ao envolvimento comunitário.

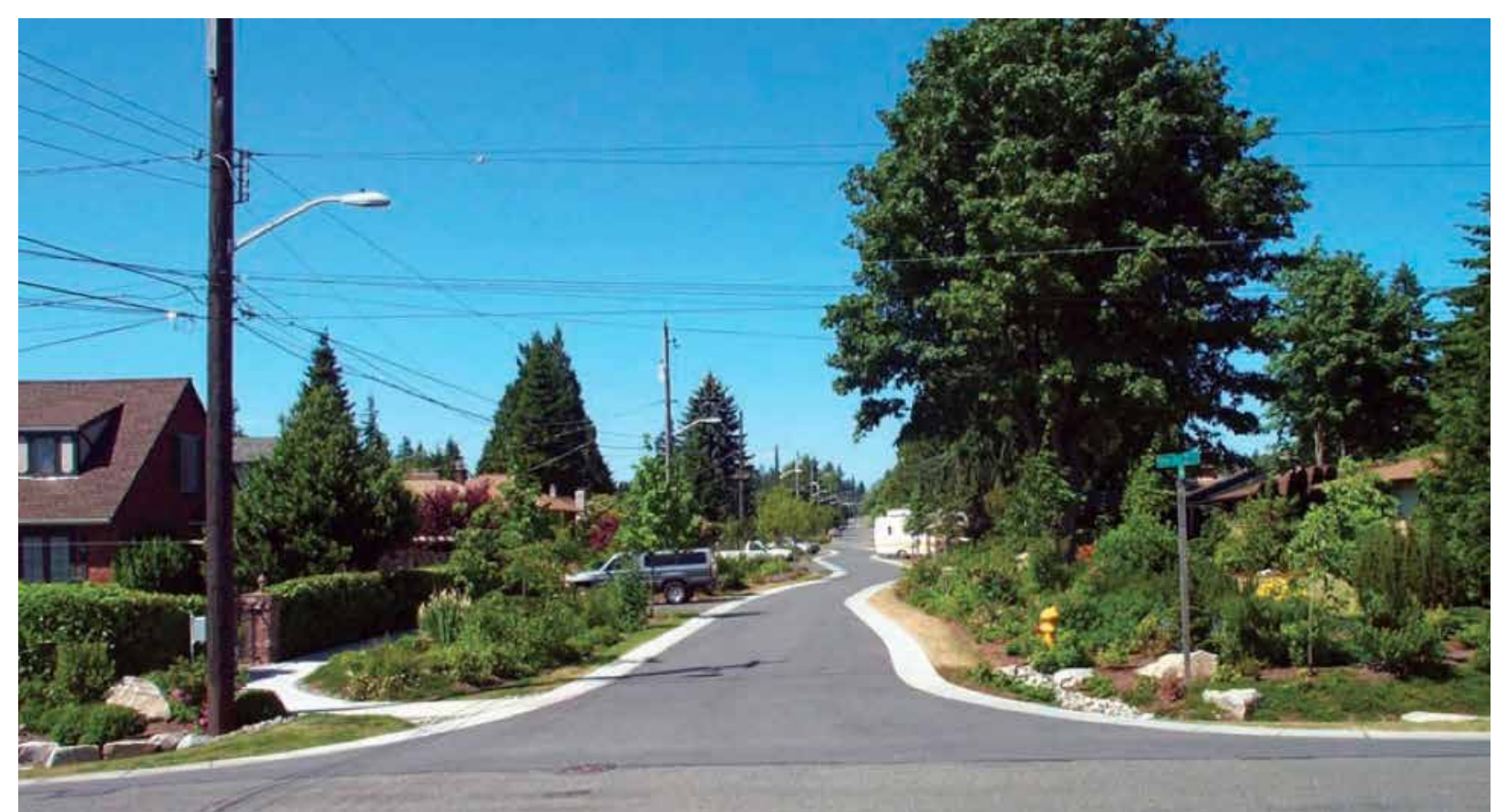

Capítulo 5 - Seattle e Los Angeles: projetos de infraestrutura verde na escala do bairro 
A área impermeabilizada foi reduzida em $11 \%$ na SEA Street e as águas pluviais superficiais foram reduzidas a $1 \%$, demonstrando o alto desempenho dos jardins de chuva projetados ao longo das calçadas somados à ação da copa das árvores em reter as águas.

\subsubsection{REQUALIFICAÇÃO DO BAIRRO HIGH POINT}

O bairro de High Point teve início durante a Segunda Guerra Mundial, com a construção de 750 casas para operários, entre casas térreas e sobrados, na região oeste de Seattle. Como projeto de requalificação desta área, foi implantado o projeto HOPE VI da Secretaria de Habitação, Seattle Housing Authority (SHA), com a criação de um empreendimento com variedade de rendas que incluía moradias de aluguel social, conjuntos habitacionais para idosos e casas de valor de mercado. Na primeira fase, foram entregues 419 moradias para aluguel e 411 para venda a preço de mercado e todas foram inauguradas entre 2005-2007, com um total de 1.600 unidades em 2010.

A fim de criar melhores conexões com a cidade, os cul-de sacs, ruas sem saída, foram eliminadas e por fazer parte de $8 \%$ do cinturão verde da bacia do Longfellow Creek surgiu uma ótima oportunidade para se implantar o sistema de drenagem natural em todo o bairro.

O sistema de drenagem natural de High Point faz parte do Projeto de requalificação de High Point e se estende por 34 quadras, da avenida 35th Ave SW à High Point Drive SW e SW Juneau St. à SW Myrtle St. O projeto é do escritório da SvR Design localizado em Seattle. O plano geral do bairro de High Point foi concebido antes da decisão de torná-lo parte do sistema de drenagem natural da cidade de Seattle. São 34 quadras com novas ruas, 485.640 metros quadrados dotados de nova infraestrutura, com arborização urbana, calçadas, parques e espaços abertos, 1.600 unidades habitacionais, centro comunitário, biblioteca e uso misto. 
Figura 37:

Corte de rua típica do bairro High Point desenvolvido pelo escritório SvR Design Company de Seattle.

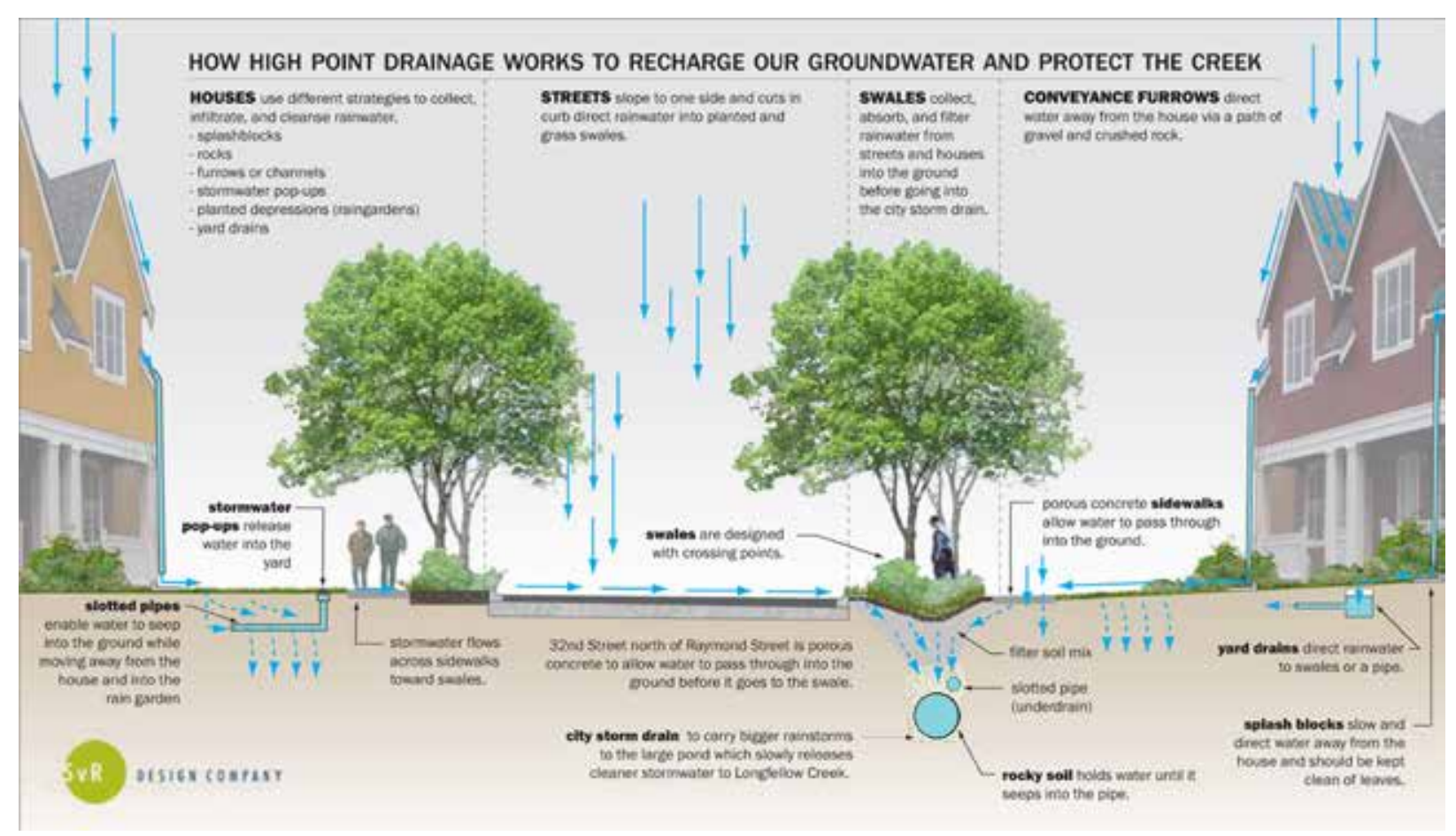

Devido ao seu tamanho e sua relação com o riacho Longfellow, o bairro de High Point, no lado oeste de Seattle se tornou, para a SPU, Secretaria de Infraestrutura, uma oportunidade única para se implementar um sistema de drenagem natural em grande escala no meio urbano.

O projeto preservou aproximadamente 107 árvores, por seu papel na drenagem e contribuição para a qualidade visual do bairro e, ao completar a segunda fase, cerca de 3.000 árvores novas foram plantadas. As águas pluviais, das chuvas de período de retorno de dois anos, não são mais despejadas no Longfellow Creek e o bairro inteiro funciona como uma grande área verde para infiltração das águas pluviais.

Dentre as técnicas aplicadas em High Point destacam-se:

- Biovaletas plantadas com ralos de fundo em um dos lados da rua provêem filtração e bioremediação de poluentes. Elas também retêm a água, diminuindo a velocidade de vazão para as lagoas e para o Longfellow Creek. O fluxo das ruas entra nos jardins de chuva através de interrupções nas guias de acabamento da pavimentação.

- O sistema atinge os padrões de qualidade da água ao tratar as águas de superfície de 6 meses, tempestades de 24 horas; 
Jardim de chuva no bairro de High Point. Foto: PriscillaTiba.

- Dispositivos projetados por artistas conduzem as águas de telhado por infiltração nos jardins de chuva e nos gramados.

- Área de playground gramada entre blocos residenciais retém as águas pluviais;

- Metade das calçadas e uma quadra da rua residencial foram pavimentadas com concreto permeável para testar a eficiência do novo material. A maioria dos estacionamentos do bairro já utilizam pisos de concreto intertravado ou pedrisco, para auxiliar na infiltração.

- As vias foram projetadas com 8 metros de largura, mais estreitas do que o usual para ruas residenciais, a fim de reduzir áreas impermeáveis e a velocidade do tráfego. As guias apresentam interrupções para a captação das águas e os jardins de chuva possuem em média 4 metros de largura entre a rua e a calçada;

- Foi instalado um sistema convencional de drenagem para conter as águas de chuvas de período de retorno de 25 anos ou tempestades mais intensas;

- Boa parte da água captada na área do projeto vai para uma lagoa de retenção que foi dimensionada para tempestades de período de retorno de 25 anos e 100 anos.

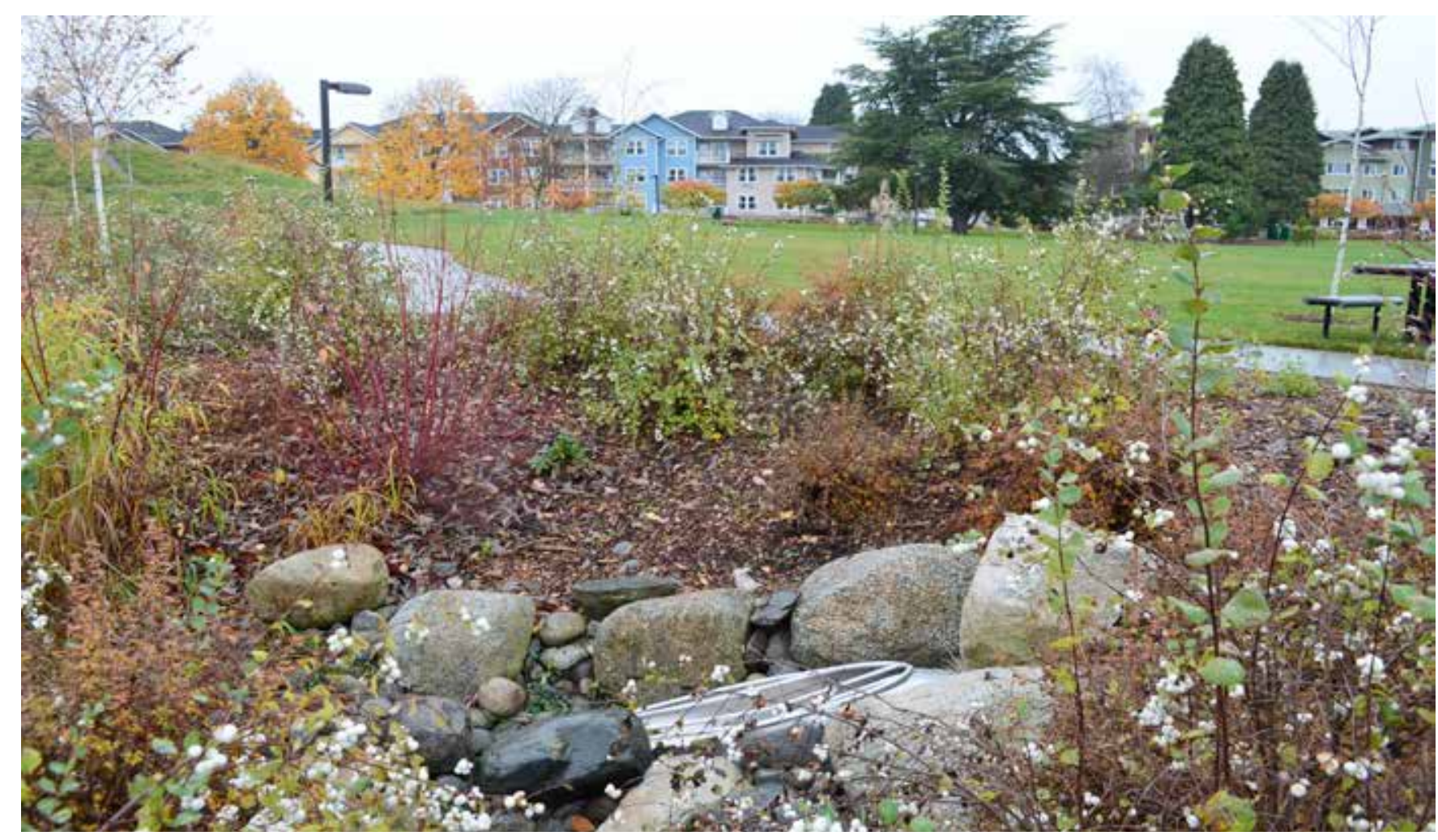




\subsubsection{Benefícios}

O sistema de drenagem natural de High Point foi projetado em parceria com a Seattle Housing Authority, que planejou a requalificação do bairro em 2003, equivalente a uma Secretaria de Habitação. O sistema trata cerca de 10 por cento da bacia do riacho Longfellow, uma das bacias hidrográficas prioritárias da cidade de Seattle.

O sistema de drenagem natural reproduz a natureza de diversas formas e através de biovaletas, canaletas de drenagem superficial com vegetação, absorve e filtra naturalmente as águas pluviais e as lagoas vegetadas ou pequenos alagados retêm as águas, a fim de prevenir enchentes. Como resultado, o bairro de High Point desempenha a mesma função que uma floresta de planície ao processar a água; corresponde à forma de ocupação urbana que adota como princípio do Urbanismo Ecológico, paisagem de alto desempenho, a natureza e suas funções como base conceitual para implantação do desenho urbano.

O projeto de High Point é considerado como exemplo e referência para outros empreendimentos em grande escala, tanto na cidade de Seattle como para empreendimentos em outras cidades dos Estados Unidos.

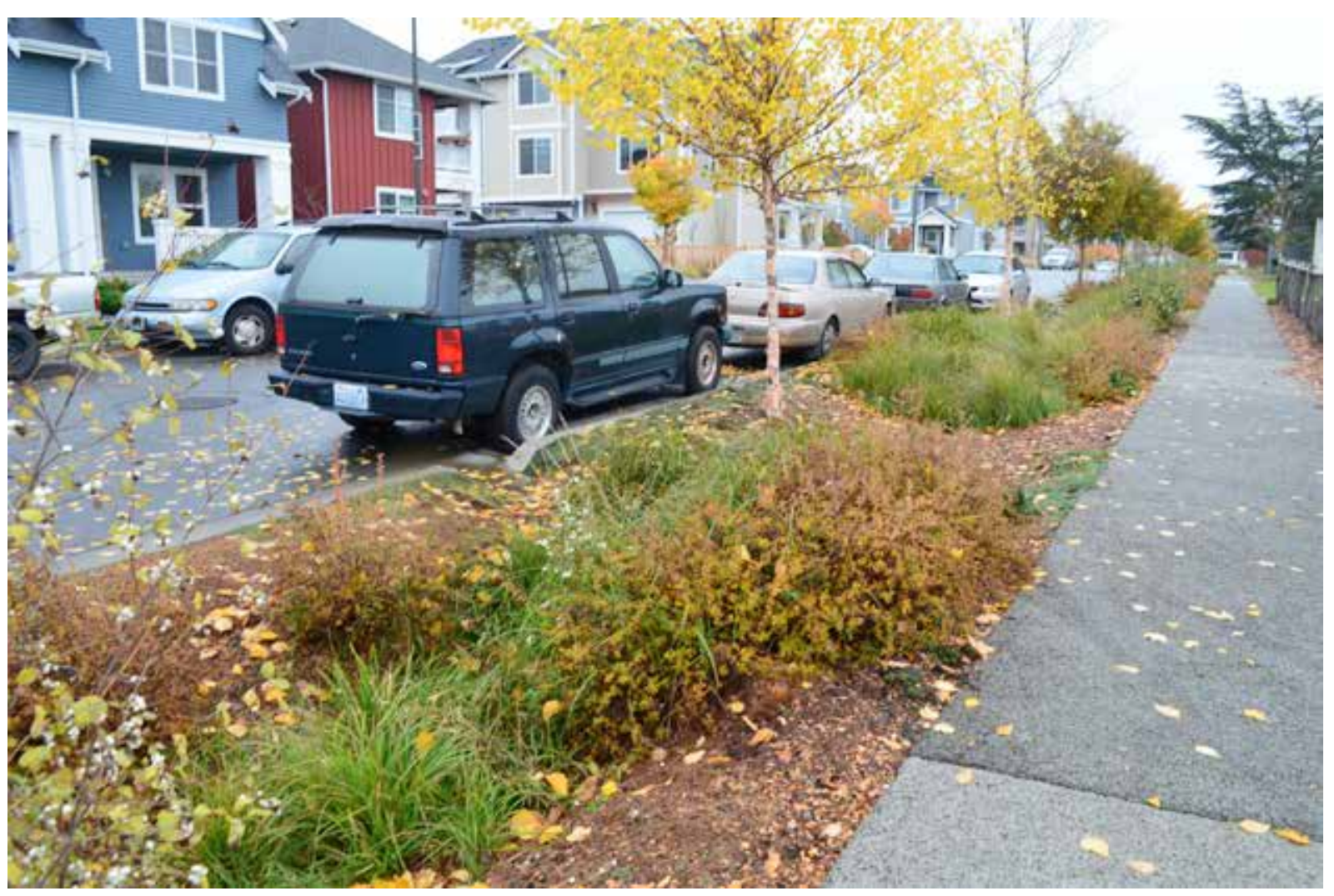




\subsubsection{Cronograma de implantação}

A construção da primeira fase do Projeto foi concluída na Primavera de 2005 e a segunda fase foi implantada em 2009. A Seattle Public Utilities iniciou o monitoramento da primeira fase do High Point em Janeiro de 2007. O financiamento das obras veio através da parceria entre a Seattle Public Utilities, Washington State Department of Ecology e a U.S. Environmental Protection Agency, Agência Americana de Proteção Ambiental.

Como resultado do monitoramento, a taxa de infiltração de água foi medida de 10,66 $\mathrm{cm}$ por hora a $15,50 \mathrm{~cm}$ por hora, o dobro do que inicialmente havia sido calculado. $O$ monitoramento é muito importante, pois suas informações permitem um aperfeiçoamento do sistema, a redução de custos e determina os requisitos mínimos para uma manutenção de longo prazo.

\subsection{RUA CASCADE E A RUA NOROESTE 110}

A Avenida Greenwood Avenue North fica próxima ao projeto piloto SEA Street, uma via arterial de uso do solo predominantemente residencial, com edifícios de apartamentos e condomínios. As águas pluviais de superfície deságuam no riacho Piper Creek e o sistema de drenagem implantado encontrava-se sobrecarregado.

A topografia local constitui-se de declividades que variam de $1 \%$ a $8 \%$, o que demandou um projeto de drenagem natural mais robusto em virtude da velocidade de vazão das águas. A valeta existente era de asfalto a fim de prevenir erosões e durante chuvas intensas enchia e extravasava para a Avenida Third NW, outra arterial importante no eixo norte e sul. O modelo projetado de sistema natural aproxima-se de um riacho de montanha.

A fim de reduzir a velocidade das águas, as calçadas da Rua Noroeste 110 e da Rua Cascade foram projetadas com uma série de "piscinas" rasas, com seixos no fundo, escalonadas gradativamente ladeira abaixo e intercaladas com uma série de pequenas barragens projetadas para temporariamente reter o fluxo dentro de cada biovaleta. Ao diminuir a velocidade de vazão, partículas sólidas e poluentes decantam e se separam da água ficando presas ao solo 
no fundo de cada "piscina". A vegetação nas laterais se desenvolveu e escondeu a maior parte do sistema cuja construção terminou em 2002.

\subsection{A MALHA VERDE BROADVIEW}

A malha verde Broadview teve seu projeto de drenagem natural implantado em grande escala para servir de laboratório e fornecer dados de monitoramento da bacia de Piper Creek. O grid incorpora a SEA Street e a Rua 110th Street Cascade. São no total 15 quadras, formando um grid verde que inclui 4 vias paralelas SEA Streets entre a Rua Cascade, Rua 110th Street e 6 quadras Rua 107th Street. As quadras entre a 107th e a Cascade coletam as águas superficiais do grid verde das SEA Streets, uma área de aproximadamente 40 hectares, além disso, diminuem a velocidade de fluxo e infiltram boa parte da água de 88 hectares ao longo da movimentada Avenida Greenwood North.

O sistema funciona de forma descentralizada com a atenuação do fluxo e a melhoria da qualidade da água através de lagoas de retenção e jardins de chuva. $\mathrm{O}$ padrão de qualidade da água é o mesmo que o exigido para qualquer empreendimento com novas superfícies impermeáveis pelo código de drenagem da Prefeitura de Seattle: tratamento completo de uma tempestade de 24 horas, a cada 6 meses mas obtida a partir de sistemas naturais.

As biovaletas e as piscinas em cascata ajudam na redução do pico e duração dos fluxos de eventos com período de retorno de dois anos e chuvas menos intensas. Os solos utilizados são especiais, com uma mistura de composto orgânico a fim de controlar a infiltração, dependendo do local e do objetivo. As biovaletas do sistema de grid verde absorvem cerca de 1,2 cm a 3,8 cm de água por hora. A água retida nas biovaletas se infiltra dentro de 72 horas após o final da tempestade, o que previne a proliferação de mosquitos.

O sistema possui uma tubulação na Avenida Fourth Ave que conduz as águas da 107th Cascade morro abaixo até o riacho Piper Creek.

A construção das obras civis da malha verde Broadview terminou em 2004 e o projeto de arquitetura paisagística de plantio foi implantado em 2005. 

Imagem de implantação do jardim de chuva das ruas 67 th Street e 28th Avenue (NW). Foto: Priscilla Tiba.

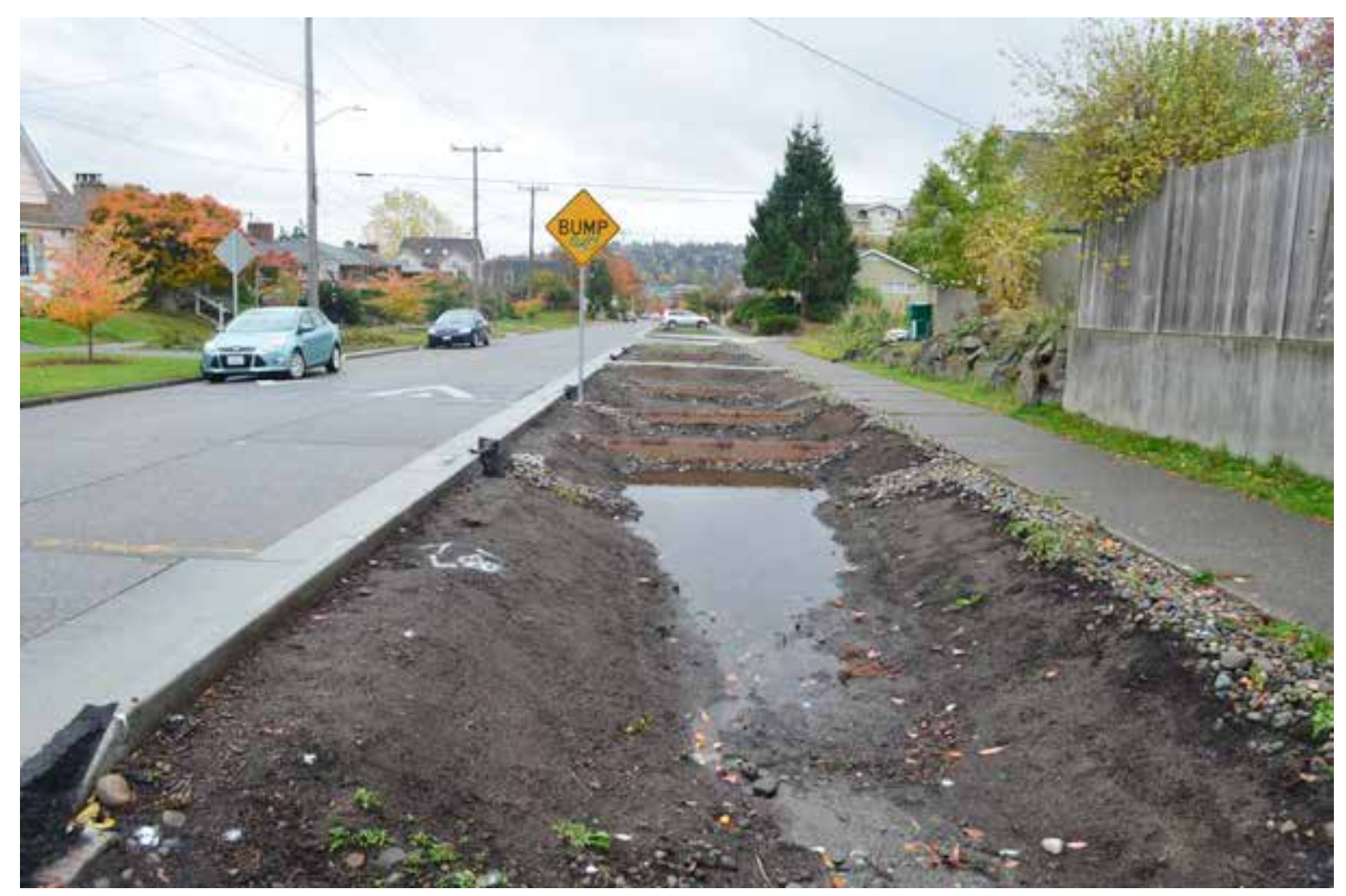

\subsection{A MALHA VERDE PINEHURST}

Os diversos cursos d'água que se ramificam do riacho Thornton drenam boa parte da área compreendida entre o nordeste da cidade de Seattle e a sua orla norte. Nesta área há uma série de empreendimentos comerciais e corporativos, dentre os quais se destaca o Northgate Mall, onde foi implantado em 2004 um sistema de drenagem natural na área do estacionamento.

Como na bacia do riacho Piper Creek, onde foi construída a primeira SEA Street, as grandes áreas residenciais próximas ao riacho Thornton Creek contribuíam com toda a água pluvial superficial diretamente para o curso d'água sem nenhum tipo de tratamento. Devido ao dimensionamento das bocas de lobo existentes, o bairro sofria com enchentes.

Em 2004, a Secretaria de Infraestrutura (SPU) projetou a malha verde de Pinehurst a partir da experiência acumulada na implantação da malha verde de Broadview Green Grid. Os projetistas aproveitaram os dados disponíveis de monitoramento e puderam dimensionar o sistema para um melhor desempenho. Como resultado, eles testaram novas formas de 
abordagem para o desenho de biovaletas e elementos desenvolvidos para o modelo de SEA Streets e para o sistema de grandes volumes de Cascades.

No modelo adotado em Pinehurst, a pavimentação foi executada em um dos lados da via, com isso, a área de canteiros de jardins de chuva e biovaletas ganhou largura para infiltração no lado oposto. Através de cálculos, os projetistas concluíram que a área a ser drenada extrapolava a rua de implantação para uma área de três a cinco vezes do seu tamanho, o que eliminou a necessidade de construção de biovaletas em ruas próximas. Um grande ganho, uma vez que a implantação do sistema em ruas existentes depende da vontade da comunidade e da coordenação de toda a infraestrutura, a fim de viabilizá-la.

Devido a estas mudanças de projeto, as seis ruas SEA Streets, com quadras de aproximadamente 220 metros de comprimento no bairro de Pinehurst, são capazes de reter, tratar e drenar as águas de seis quadras adicionais que receberam melhorias na infraestrutura tradicional de drenagem como grelhas, mas não tiveram implantadas biovaletas e plantio.

As estratégias empregadas promoveram a redução dos custos de implantação das malhas verdes. Com exceção do piso permeável que foi usado pela primeira vez na reconstrução de algumas rampas de acesso a garagens da malha verde de Pinehurst, os demais elementos seguiram o projeto já desenvolvido para a primeira SEA Street.

As ruas que antes não possuíam calçadas ganharam uma nova calçada em um dos lados, uma nova pavimentação viária, com a largura menor para diminuir a área de superfície impermeável, áreas plantadas dentro das biovaletas e ao redor das mesmas, nos jardins de chuva e nova arborização ao longo de todas as vias.

O projeto da malha verde Pinehurst incluiu 12 quadras urbanas, entre a Rua 113th St. a Rua 117th St. e as Avenidas 16th Ave. e 23rd, além do projeto no cruzamento da rua 113th St. com a 25th que foi reconstruída e plantada. 


\subsection{DESAFIO}

O atual desafio da Secretaria de Infraestrutura Seattle Public Utilities é a implantação do sistema de drenagem natural em áreas mais densas. $O$ modelo foi bem sucedido em ruas onde não havia guias, sarjetas e calçadas além da ausência de um sistema de drenagem convencional. No entanto, estas não são as únicas ruas com problemas de drenagem na cidade. Em algumas áreas, onde o sistema de águas pluviais é combinado com a rede de esgotos, durante chuvas muito intensas, as tubulações podem extravasar e despejar esgoto sem tratamento no Lago Washington e em Puget Sound.

Seattle está sob a pressão de diretrizes federais e estaduais para reduzir o problema da poluição das águas. $O$ enquadramento dentro dos padrões exigidos é possível através da eliminação de tanques de retenção e da implantação do sistema de drenagem natural a montante.

Em 2008, a Prefeitura lançou o código de drenagem revisado com a implementação do sistema de crédito de drenagem Rainwise, com o foco na redução do impacto das águas pluviais provenientes das propriedades privadas.

O programa de drenagem natural continua canalizando esforços na implantação do sistema nas vias públicas, o que representa mais de $25 \%$ da área urbana e nas propriedades privadas que despejam suas águas sobre a via pública. Atualmente, o desafio encontra-se na implantação do sistema em bairros mais densos. A seguir, apresenta-se uma série de técnicas propostas para tal implantação:

- Manter as árvores existentes de grande porte para manter a cobertura vegetal que intercepta a água da chuva e facilita a infiltração;

- Instalar grelhas de infiltração e captação nos canteiros, a fim de prover retenção ou infiltração dependendo do projeto;

- Reduzir o fluxo de superfície através de infiltração direta no pavimento permeável de ruas e calçadas; 
- Construir sistemas de bioretenção lineares nos canteiros ou nas áreas contínuas de plantio de árvores ao longo da rua;

- Construir biovaletas plantadas interconectadas similares a SEA Streets com o plantio linear, eliminação de parte das áreas de estacionamento da rua de um lado nos bairros residenciais. A água entra nos jardins de chuva através de interrupções das guias;

- Onde é possível se separar o fluxo de sistemas combinados, tratar as águas através de bioretenção ou biofiltração até a descarga em cursos d'água.

\subsection{O CASO DO PROJETO PIGGYBACK YARD EM LOS ANGELES, CALIFÓRNIA}

Com o objetivo de transformar a cidade de Los Angeles através da melhoria da relação da ecologia com a comunidade, o Plano Geral Conceitual para o Piggyback Yard teve como objetivo regenerar um terreno pós-industrial degradado através da transformação do Rio Los Angeles como um corredor vital para a cidade. O projeto é resultado da colaboração de uma equipe multidisciplinar que trabalhou pro bono com a visão de melhorar a qualidade de vida urbana e criar um novo paradigma para a expansão urbana de Los Angeles. A equipe foi formada por Michael Maltzan, Marc Salette, Perkins + Will, Jackie Kain, e Mia Lehrer + Associates e teve como cliente a organização Friends of the Los Angeles River.

O plano para revitalização urbana transformou uma área intermodal pertencente à companhia ferroviária Union Pacific em uma área estratégica para a várzea do rio e seu fluxo e provê cerca de 32 hectares de espaços livres, empreendimentos de uso misto ao longo de seu perímetro, além de estabelecer conexões importantes entre o rio e a área central da cidade. O projeto tem como característica a bioengenharia, no que tange à hidrologia, a criação de 6 hectares de vegetação ripária recuperada e o uso de boa parte do terreno para o controle de enchentes.

A fase 2 do projeto aprofundou aspectos hidráulicos e possibilidades hidrológicas e de desenvolvimento econômico com a colaboração das empresas Geosyntec Consultants, ELP Advisors e com os arquitetos paisagistas da equipe original do plano geral Mia Lehrer e Benjamin Feldmann. 
O projeto reflete os princípios do Plano de Revitalização do Rio Los Angeles, organizado pela Prefeitura de Los Angeles e elaborado por uma equipe multidisciplinar da qual fez parte a arquiteta paisagista Mia Lehrer. São eles: fornecer oportunidades para a revitalização do rio através de recuperação ecológica, transformar espaços livres subutilizados ou vagos ao longo do leito do rio em áreas verdes para uso comunitário e, desta forma, fortalecer conexões da comunidade com o rio, identificar oportunidades para melhoria e reinvestimento nos bairros e criar valor através da melhoria da qualidade de vida dos residentes, aumentando a atratividade da cidade como um lugar para morar e trabalhar.

A visão do projeto Piggyback Yard fornece diretrizes de modo a atender todos os princípios para criar oportunidades de regeneração ecológica, desenvolvimento sustentável e de reinvestimento na comunidade. O projeto tem como foco a relação holística entre infraestrutura, desenvolvimento e paisagem, princípio do Urbanismo Ecológico de forma a equilibrar benefícios econômicos, culturais, ecológicos e hidrológicos.

O programa hidrológico inclui elementos para a melhoria da qualidade da água, através da biofiltração com o incremento da permeabilidade e da vegetação de mata ciliar e aumento da capacidade de retenção das águas pluviais na várzea. Tais elementos estabeleceram uma conexão forte entre o Piggyback Yard e o Rio Los Angeles tornando o sítio um importante destino ao longo do rio para a comunidade.

O programa de projeto, em uma área total de 71 hectares, engloba empreendimentos de uso misto, campus educacional para University of Southern California, USC, e um distrito de arte. Por estar próximo da estação de trem Union Station, no centro de Los Angeles, os usuários são estimulados a caminhar e a utilizar o transporte público, o que fortalece a ideia de se criar espaços públicos interessantes em toda a vizinhança.

O plano geral apresenta uma extensa área verde central que tem origem na margem do rio onde foram criadas ilhas rodeadas por alagados e um habitat ripário que desempenham uma importante função para o controle de enchentes. 
Figura 41:

Plano geral do Piggyback Yard, área verde central e alagados para controle de enchentes. Fonte: Piggyback Yard Feasibility Study, créditos: MLA e Geosyntec.

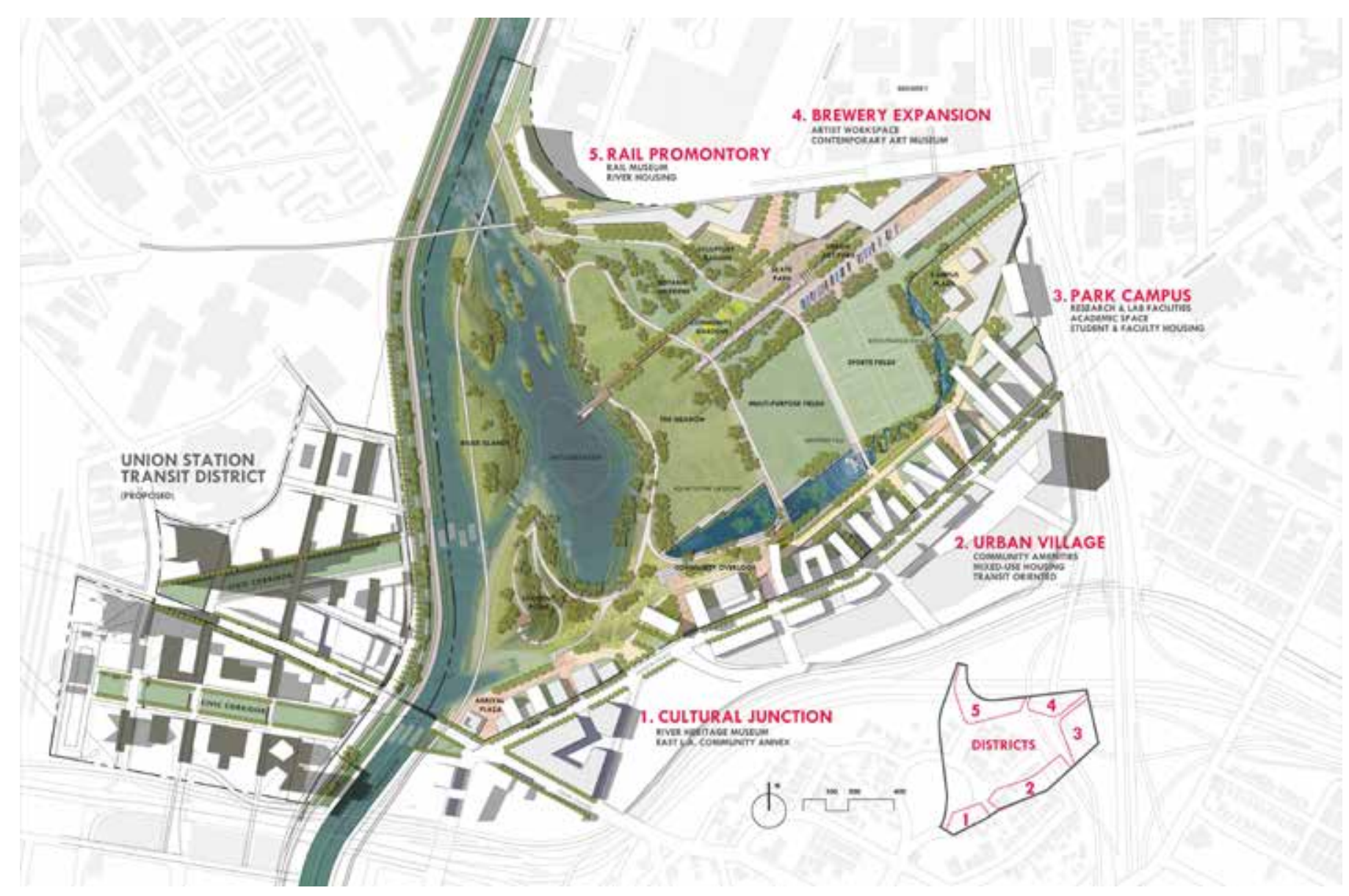

Ao longo da Mission Road, o projeto propõe empreendimentos de uso misto, áreas institucionais e um distrito de arte. São previstas atividades durante 24 horas, 7 dias por semana, propiciadas pela localização do terreno próximo ao centro e de terminais intermodais. Este novo destino no rio simboliza a renovação econômica da área, ao mesmo tempo em que incrementa as áreas verdes e recreacionais como apoio aos esforços de recuperação ambiental do rio.

O projeto cria uma interação significativa entre as pessoas e a natureza através da criação de acessos ao rio e a revitalização de suas margens, com a implantação da vegetação ripária. As áreas verdes propiciaram a valorização da terra, o que despertou o interesse do mercado imobiliário pelo desenvolvimento da área. O projeto exemplifica a noção de regeneração urbana e emprega um sistema baseado na infraestrutura verde que maximiza os benefícios da ecologia para as pessoas e para o lugar. 
Figura 42:

Imagem área do Piggyback Yard ilustrando sua proximidade com a rede de infraestrutura de transportes e a área central da cidade de Los Angeles. Fonte: PBy Masterplan, PBy Collaborative Design Group (MLA, Perkins+Will, Michael Maltzan e Chee Salette)

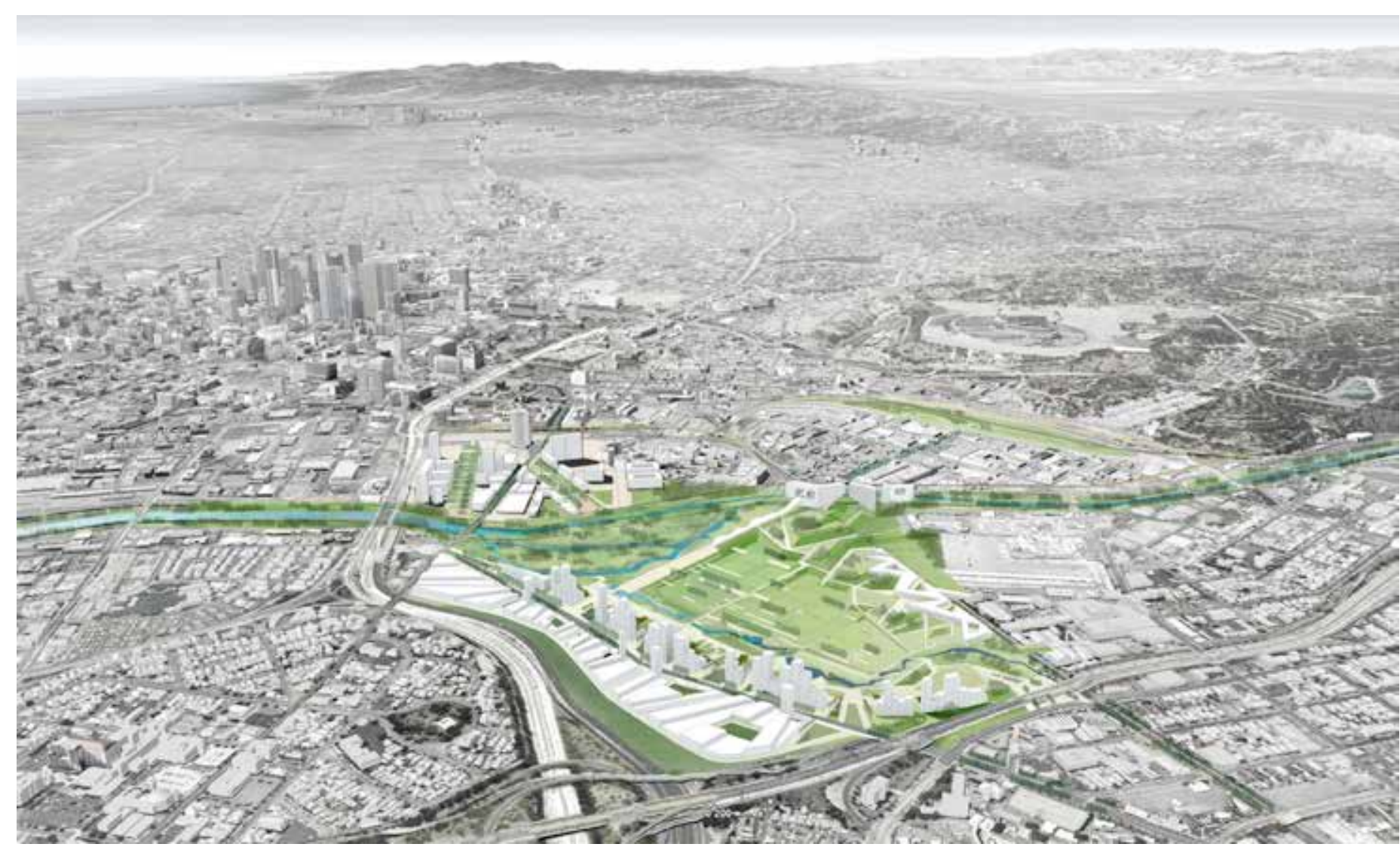

A transformação de áreas industriais centrais em áreas de expansão para o crescimento metropolitano representa um processo de mudança do século 21. A cidade de Los Angeles aproveita a oportunidade de reconverter usos de áreas subutilizadas e dotadas de infraestrutura, ao mesmo tempo em que não elimina o uso industrial próximo à ferrovia e o concilia com outros usos como o residencial, através do estímulo à instalação de indústria limpa.

O planejamento para o futuro das cidades deve recalibrar o seu sistema de infraestrutura com a urbanização crescente e o aumento de chuvas intensas devido às mudanças climáticas. Os recentes eventos nos Estados Unidos das tempestades Sandy e Katrina ilustram as consequências e a severidade da destruição que os mesmos podem causar. O Urbanismo deve incorporar os sistemas naturais em seu desenho a fim de minimizar impactos e conflitos. 
Figura 43:

Vista dos alagados. Fonte: PBy Masterplan, PBy Collaborative Design Group (MLA, Perkins+Will, Michael Maltzan e Chee Salette).

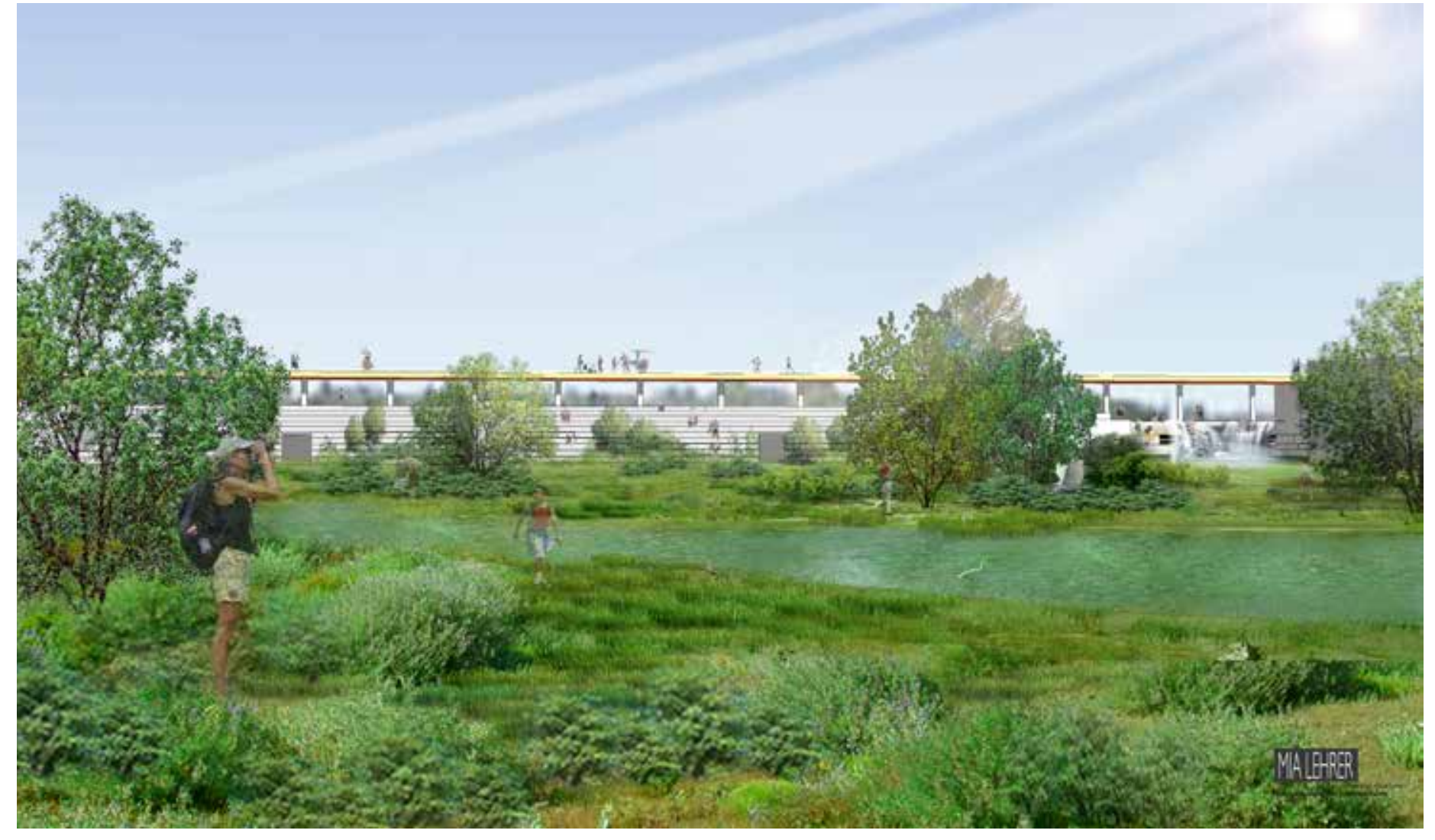

Figura 44:

Vista da belvedere.

Fonte: PBy Masterplan, PBy

Collaborative Design Group

(MLA, Perkins+Will, Michael Maltzan e Chee Salette).

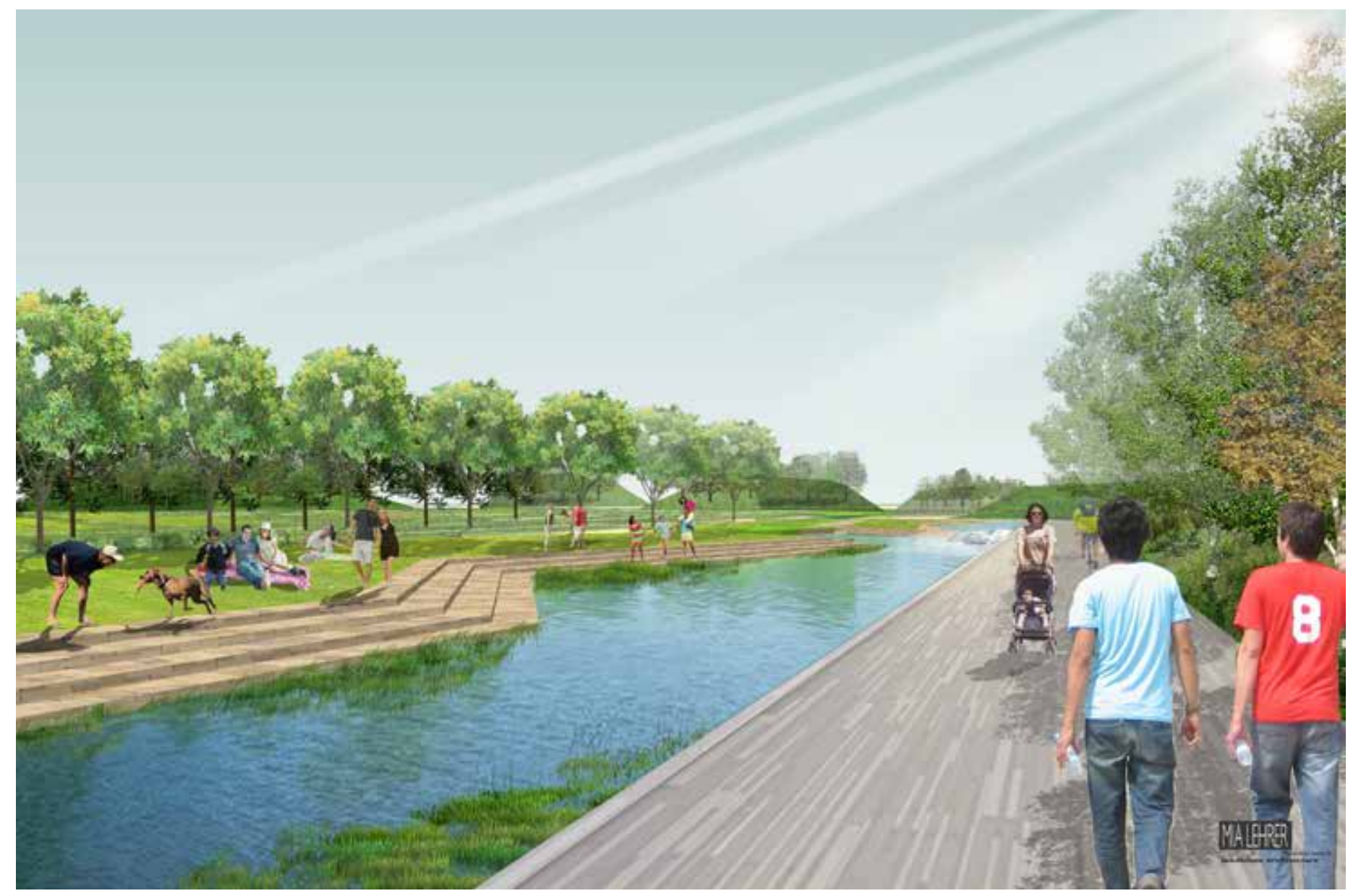





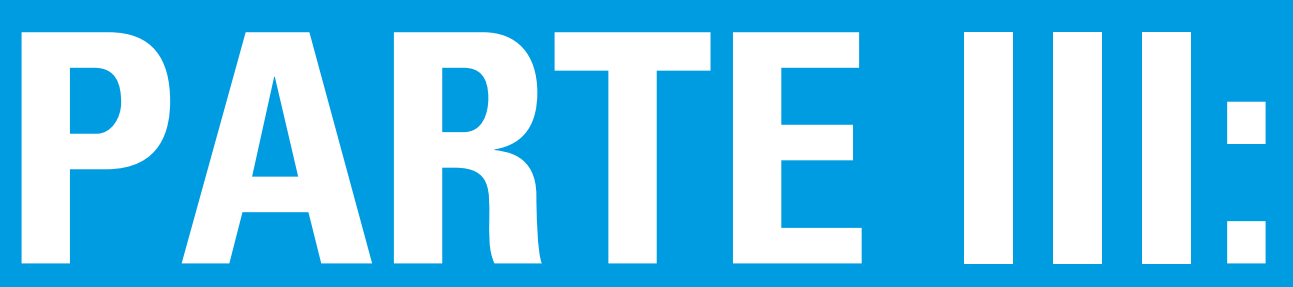

ESTÁDIOS COMO ELEMENTOS CATALISADORES DE TRANSFORMAÇÃO URBANA, OPORTUNIDADES PARA O SURGIMENTO DO URBANISMO ECOLÓGICO 


\section{CAPÍTULO 6 \\ O CASO DO AT\&T PARK EM SÃO FRANCISCO E DA ARENA STAPLES CENTER EM LOS ANGELES}

6.1 AT\&T PARK, ESTÁDIO DE BEISEBOL NA ÁREA DO PORTO DE SÃO FRANCISCO

6.2 ARENA STAPLES CENTER E O PLANO DE ESPAÇOS LIVRES PARA O CENTRO DE LOS ANGELES

6.2.1 PROTÓTIPOS PROPOSTOS PARA FUTUROS ESPAÇOS PÚBLICOS NA ÁREA DE INTERVENÇÃO

6.2.1.1 PROTÓTIPO 1 - PEQUENO PARQUE

6.2.1.2 PROTÓTIPO 2 - PEQUENO PARQUE EM VIELA

6.2.1.3 PROTÓTIPO 3 - PARQUE MÉDIO

6.2.1.4 PROTÓTIPO 4 - PARQUE GRANDE 
Em áreas urbanas já consolidadas e degradadas, uma das estratégias do poder público é a implantação de grandes equipamentos esportivos como elementos de atração de público e capital de investimento. As cidades de São Francisco e Los Angeles possuem dois exemplos de políticas bem sucedidas na reorganização e valorização de áreas urbanas originalmente subutilizadas e dotadas de infraestrutura, respectivamente, China Basin, na área portuária em revitalização e na área central da metrópole.

Os vazios urbanos foram ocupados por empreendimentos com multiplicidades de rendas e múltiplas áreas verdes com desempenho importante na infraestrutura da região, locais antes preenchidos com extensas "áreas cinzas" de concreto e asfalto, sem vitalidade. Ambos os estádios foram elementos catalisadores desta transformação urbana, pautada por princípios de Crescimento Inteligente e Urbanismo Ecológico com a implementação de áreas verdes e atividades de recreação e lazer e outros usos para atração de visitantes e novos residentes do entorno, por se tratarem de equipamentos multifuncionais, além de promoverem a melhoria da qualidade ambiental urbana.

\subsection{AT\&T PARK, ESTÁDIO DE BEISEBOL NA ÁREA DO PORTO DE SÃO FRANCISCO}

O Porto de São Francisco é uma agência pública responsável por gerenciar 12 quilômetros da orla da Baía de São Francisco na Califórnia, do píer Hyde Park Street até Indian Basin, no sul. Dentre as responsabilidades do Porto está a promoção do comércio marítimo, navegação e pesca, a recuperação ambiental e a oferta de espaços públicos destinados à recreação. $A$ área total sob sua jurisdição compreende 404 hectares.

A história do Porto inicia-se no século XIX com a corrida do ouro e a chegada de centenas de navios do mundo inteiro à Baía de São Francisco. No século $X X$, a área portuária já havia se consolidado como área industrial, repleta de terminais ferroviários, armazéns e píeres. Com a Segunda Guerra Mundial, o porto tornou-se importante centro logístico militar e na década de 50, continuou a representar uma importante área para cargas na costa oeste americana.

Ainda hoje oferece terminais de carga de alta tecnologia, áreas de armazéns cobertos e as águas profundas da baía como atrativos às atividades portuárias. Em 1968, o Estado transferiu 

São Francisco. www.sfport.com/index.aspx?pa ge $=1497 \&$ recordid $=105 \&$ returnU $\mathrm{RL}=\% 2$ Findex. asp $x>$. Acesso em: 21 de Outubro de 2012.

a responsabilidade do porto para a Prefeitura e para o Condado de São Francisco, através do Ato Burton. Como condição para transferência, a Prefeitura teve que criar a Comissão do Porto responsável por gerenciar a orla. Apesar de ser um departamento da Prefeitura, o porto não recebe recursos financeiros da mesma e se sustenta com a verba proveniente do leasing de suas propriedades.

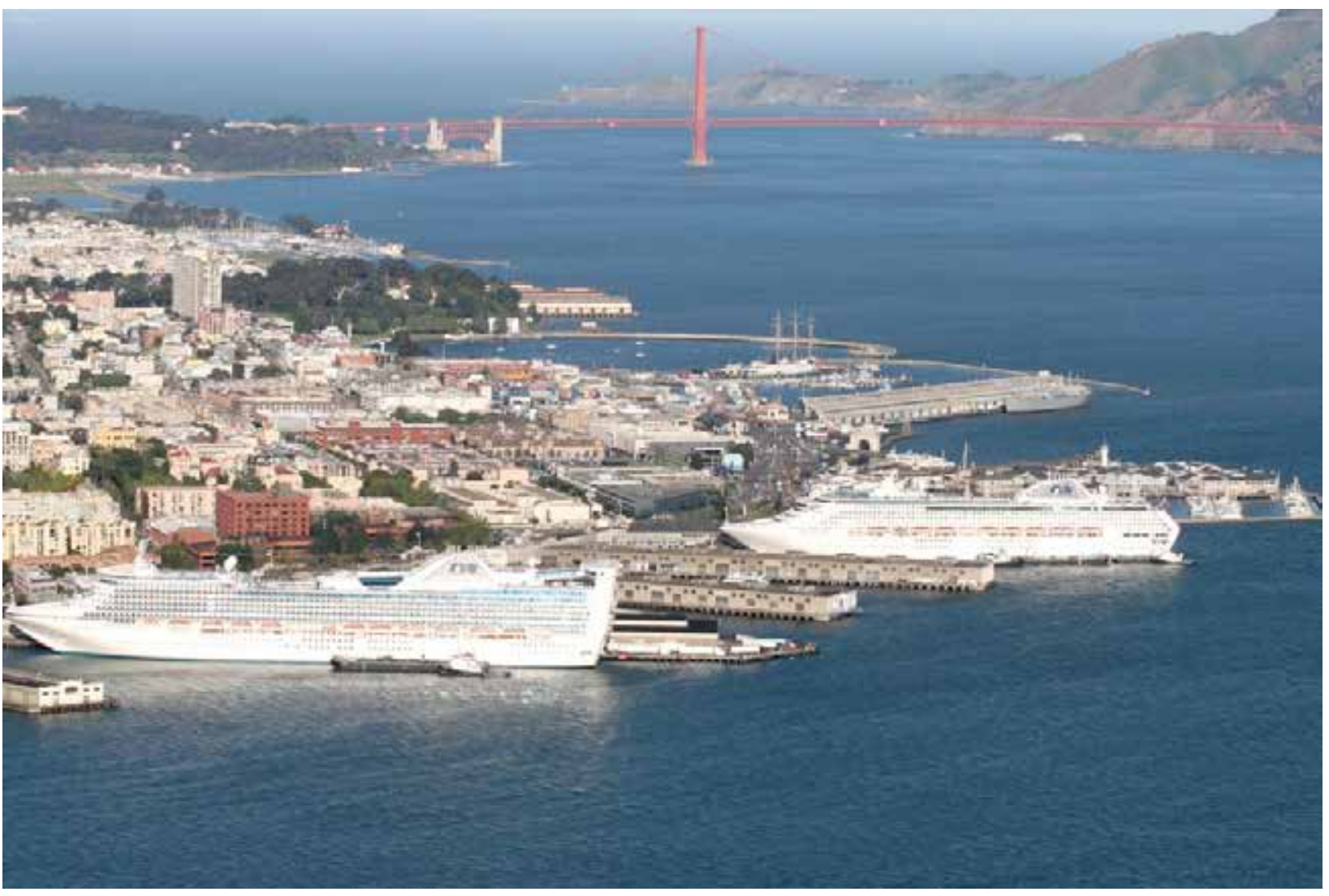

Nos últimos trinta anos, o centro da cidade cresceu em direção à orla, com a implantação de novos usos em áreas anteriormente ocupadas por indústrias. As atividades portuárias ainda se mantêm ao sul de China Basin, e ao norte prevalecem os cruzeiros marítimos turísticos, barcos de passageiros, atividades de pesca e outras atividades comerciais marítimas. Devido à qualidade visual e à vitalidade da variedade de usos a área atrai milhões de turistas por ano.

Em 1990, devido à mobilização popular, o porto criou um Plano de Uso do Solo para a Orla, Waterfront Land Use Plan, com o objetivo de equilibrar os usos e recursos. O plano reservou a maioria das propriedades do porto para a expansão de operações marítimas e encorajou novo acesso público à Baía. O plano identificou terrenos para novos empreendimentos comerciais 
a fim de incrementar as atividades na orla e ajudar a subsidiar a indústria marítima, financiar o acesso público e novos espaços livres com amplas áreas verdes e também auxiliando na contenção da degradação da área portuária.

A implantação do novo estádio AT\&T Park na região de South Beach/China Basin que se estende do Píer $221 / 2$ ao Seawall Lot 345 catalisou a transformação da área industrial subutilizada em uma área vibrante de uso misto residencial e comercial, unificada por áreas verdes contínuas ao longo da orla marítima e no sistema viário (figura 48). O estádio é conectado à cidade através do BRT (Bus RapidTransit) e de espaços livres revitalizados como o Brannan Street Wharf, um dos principais parques públicos da área (figura 47).

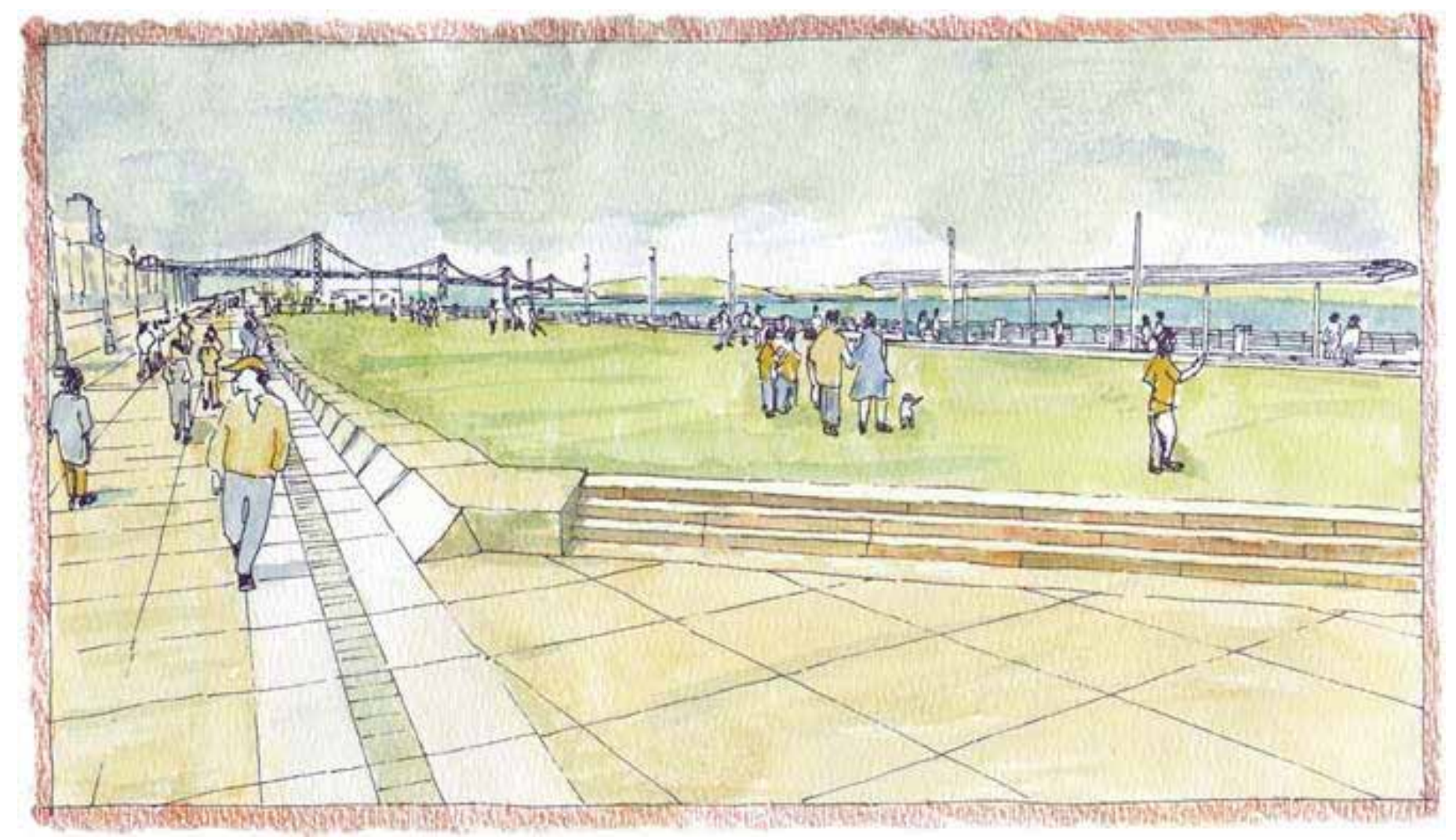


AT\&T PARK - SÃO FRANCISCO, CALIFORNIA, EUA

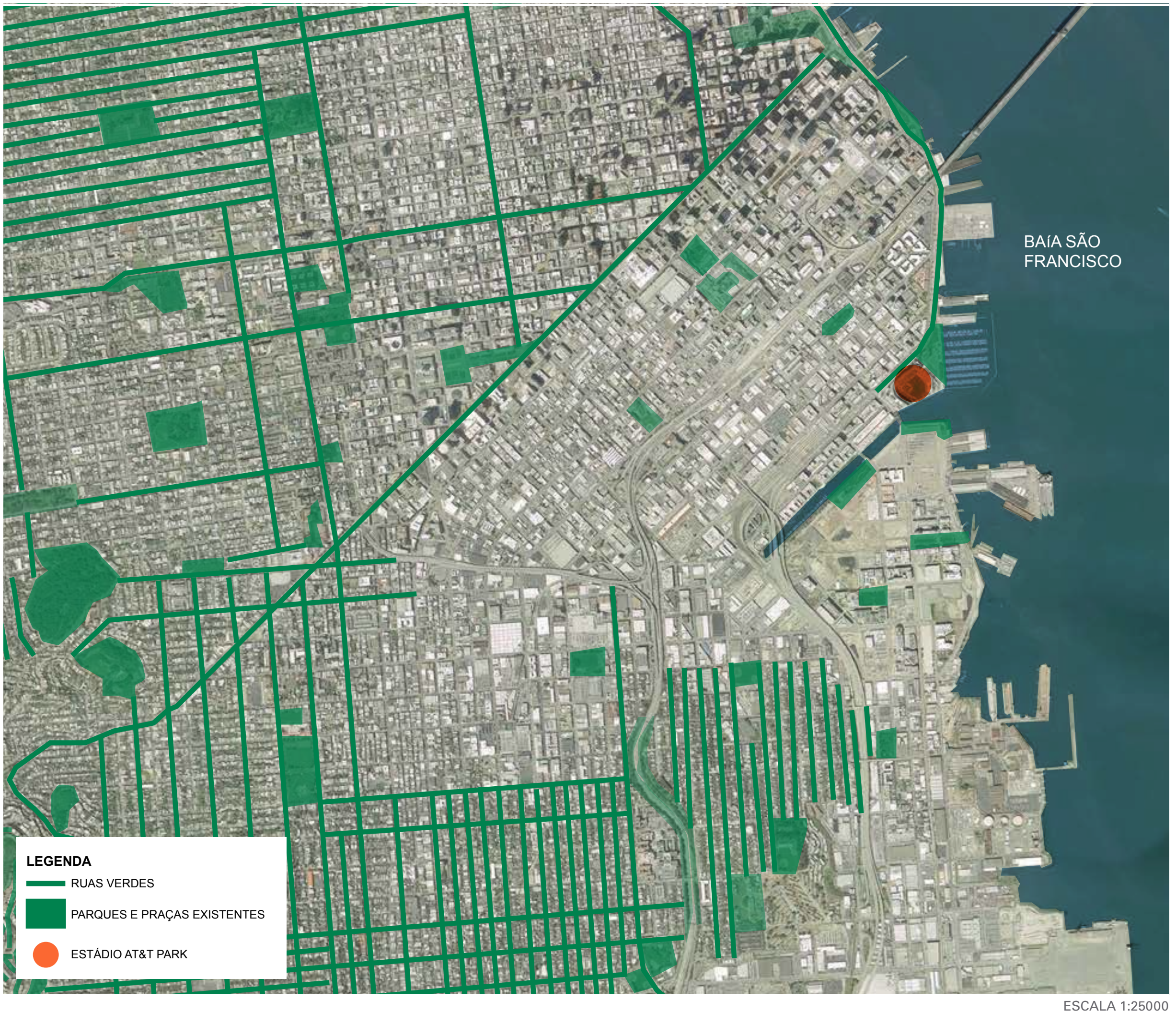

Figura 48: Espaços públicos verdes no entorno do estádio AT\&T Park. Mapeamento Patrícia Akinaga. Base: Google Earth 2013. 
Dentre os objetivos do plano para South Beach/China Basin estão:

- Respeitar as necessidades dos novos residentes;

- Criar novas atividades para atrair os residentes da Cidade de São Francisco;

- Criar conexões e acessos públicos entre South Beach e China Basin;

- Estimular o uso de barcos para recreação;

- Prover novos parques.

Figura 49:

Vista do estádio inserido na orla de China Basin. Fonte: <http:// www.sanfrancisco.giants.mlb. com>.Acesso em: 21 de Outubro de 2013.

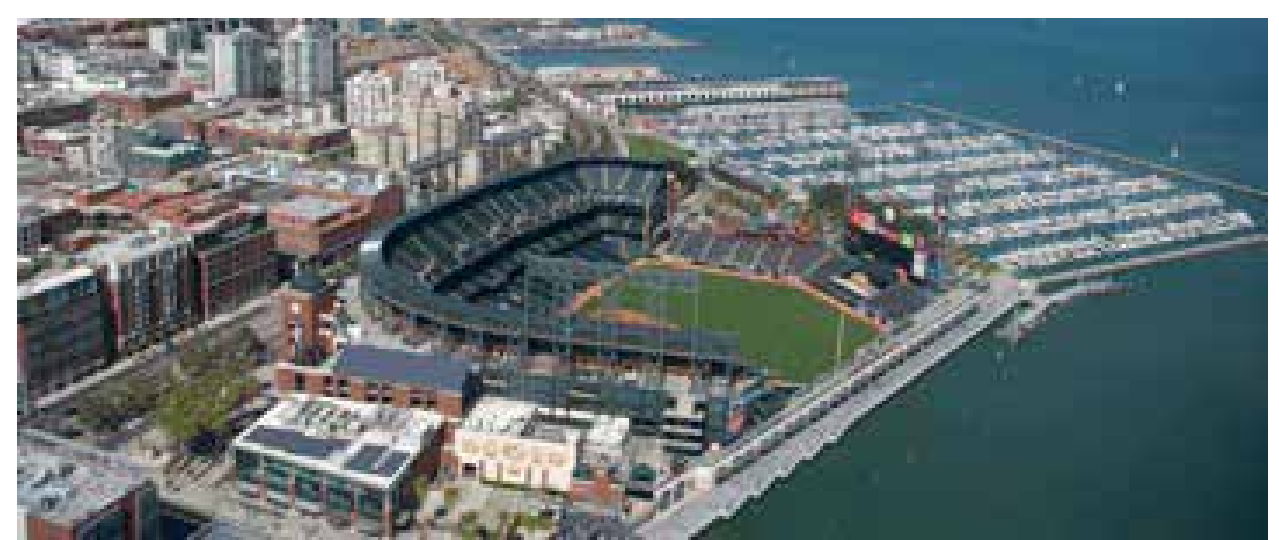

Figura 50: Vista geral do estádio e de seu entorno. Fonte: <http://www. seemyseats.com>. Acesso em: 21 de Outubro de 2013.

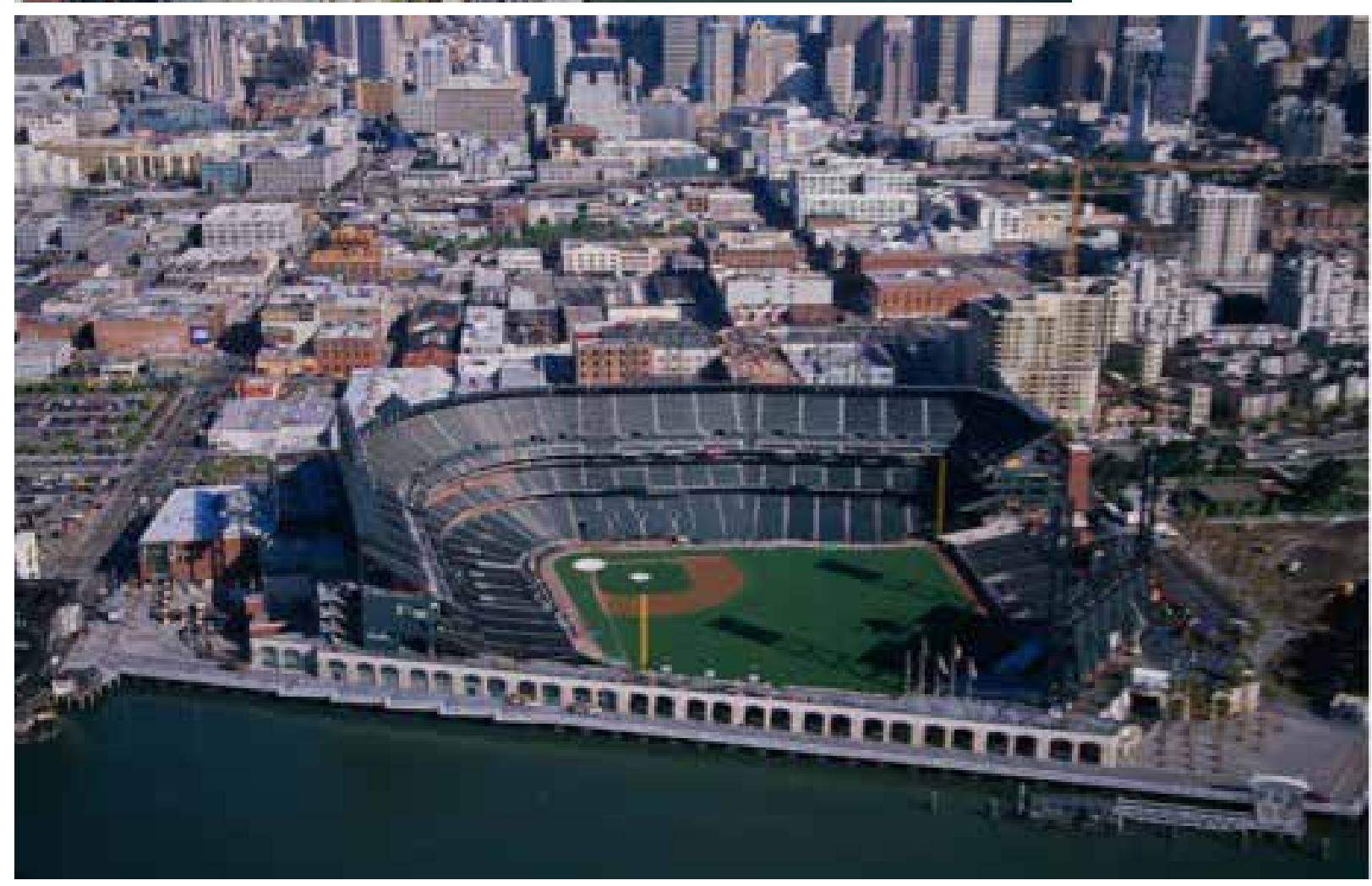

O estádio é a sede dos SF Giants, time de beisebol e foi inaugurado em 11 de Abril de 2000. Oferece vistas de todos os assentos para a Baía de São Francisco e tem capacidade para 41.503 pessoas. 
A Arena STAPLES Center faz parte do empreendimento L.A. Live, um projeto de uso misto que inclui comércio, residências, escritórios e equipamentos de entretenimento implantado no centro de Los Angeles e de autoria dos escritórios americanos Gensler e RTKL.

Em contrapartida à implantação da arena, o empreendedor L.A. Arena Land Co. comprometeu-se com a Prefeitura a implementar um programa de benefícios para a comunidade, que incluiu incrementar as áreas verdes da vizinhança, estimular o emprego local e criar novos empreendimentos habitacionais para mercado popular.

Como resultado de um acordo entre o empreendedor e a organização não governamental Figueroa Corridor Coalition for Economic Justice foi comissionado um estudo para o entorno imediato da arena. Este estudo teve como objetivo levantar as condições dos parques existentes e a necessidade por novas áreas verdes para recreação e lazer e melhorar a qualidade ambiental da área. O estudo compreendeu as áreas dos bairros densamente povoados de Pico Union, Westlake e South Park, entre outros. Estes bairros são mal servidos por equipamentos públicos e parques. Eles têm uma média de menos de 0,2 hectares de parque por mil habitantes, quando a Associação Nacional de Recreação e Parques dos Estados Unidos recomenda o mínimo de quatro hectares.

O objetivo do projeto foi desenvolver opções e protótipos de espaços livres para o uso da comunidade no entorno da arena. Tais protótipos teriam o investimento de um milhão de dólares para sua implantação durante o período de cinco anos. $O$ objetivo do estudo foi atingido através do levantamento dos equipamentos existentes, do entendimento das necessidades da comunidade e da identificação de uma série de opções para a criação de espaços livres no tecido urbano já consolidado e densamente ocupado.

$\mathrm{O}$ estudo também documentou recursos adicionais que poderiam complementar $\mathrm{O}$ aporte inicial da L.A. Arena Land Co. e incorporou um estudo de mercado imobiliário dentro da área de intervenção, que levantou custos de aquisição de propriedades e examinou estudos de caso para balizar custos de implementação. 
Figura 51:

Perímetro da área de estudo definido a partir do centro da arena STAPLES.

Fonte: Parks and Recreation Assessment Study STAPLES Center. Mia Lehrer + Associates. Base: Google Earth, 2001
O recurso deveria ser investido em uma área dentro de um raio de 1,6km de distância do centro da Arena STAPLES, no entanto, a equipe definiu um perímetro maior, de $5 \mathrm{~km}$ para o levantamento dos equipamentos existentes e dados demográficos. Verificou-se que boa parte da população residente dentro do perímetro de estudo era de baixa renda, em áreas densamente povoadas, o que ratificou a importância do estudo e do investimento. Aproximadamente 420.000 pessoas vivem na área de estudo.

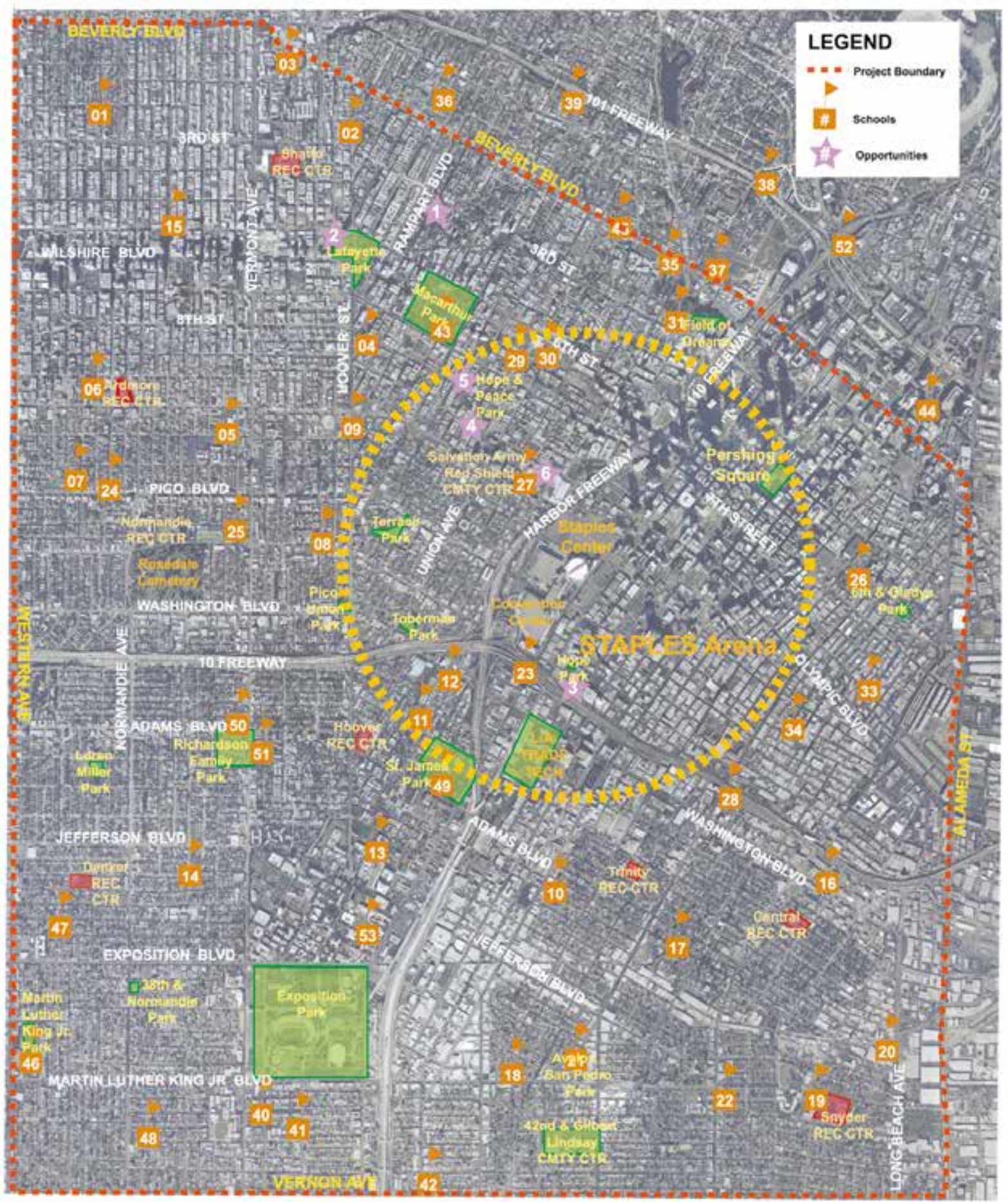


Os limites da área de estudo estabelecidos a partir de $5 \mathrm{~km}$ do centro da arena foram definidos pela Beverly Boulevard/expressa 101 ao norte, Avenida Western no lado oeste, Avenida Vernon ao sul e Rua Alameda no lado leste. (figura 51).

A participação comunitária foi fundamental para adicionar informações relevantes no processo de análise e de projeto. A participação foi estruturada através da realização de uma série de oficinas com a comunidade e stakeholders. Uma metodologia específica foi criada com a elaboração de material gráfico direcionado, a fim de se obter resultados mais efetivos. Mais de 250 pessoas atenderam duas oficinas realizadas na sede do exército da salvação e mais duas oficinas que tiveram como público a população jovem foram realizadas nos bairros de Koreatown e Pico Union. Nestas oficinas os participantes eram divididos em grupos menores e eram solicitados a expressar os seus desejos e pensamentos sobre os parques existentes, equipamentos em potencial e áreas de maior carência de investimento.

Para a análise demográfica, a equipe selecionou o mapeamento referente ao censo de 2000 dos Estados Unidos, com dados de idade, densidade, renda, número de habitantes por unidade e etnia. Os dados foram combinados de forma a identificar áreas prioritárias e de maior carência: grande número de população jovem, em áreas densamente povoadas e de baixa renda. O mapeamento identificou as áreas de Westlake, Pico Union e South Park como prioritárias para o investimento. A comunidade ratificou a informação concluída a partir dos dados e o levantamento de campo reforçou a necessidade da criação de espaços públicos verdes nestas áreas. 
Figura 52:

Mapa elaborado a partir do censo de 2000. Concentração de população por idade. Autor: PCR consultants. Fonte: Parks and Recreation Assessment Study STAPLES CENTER. Mia Lehrer + Associates.

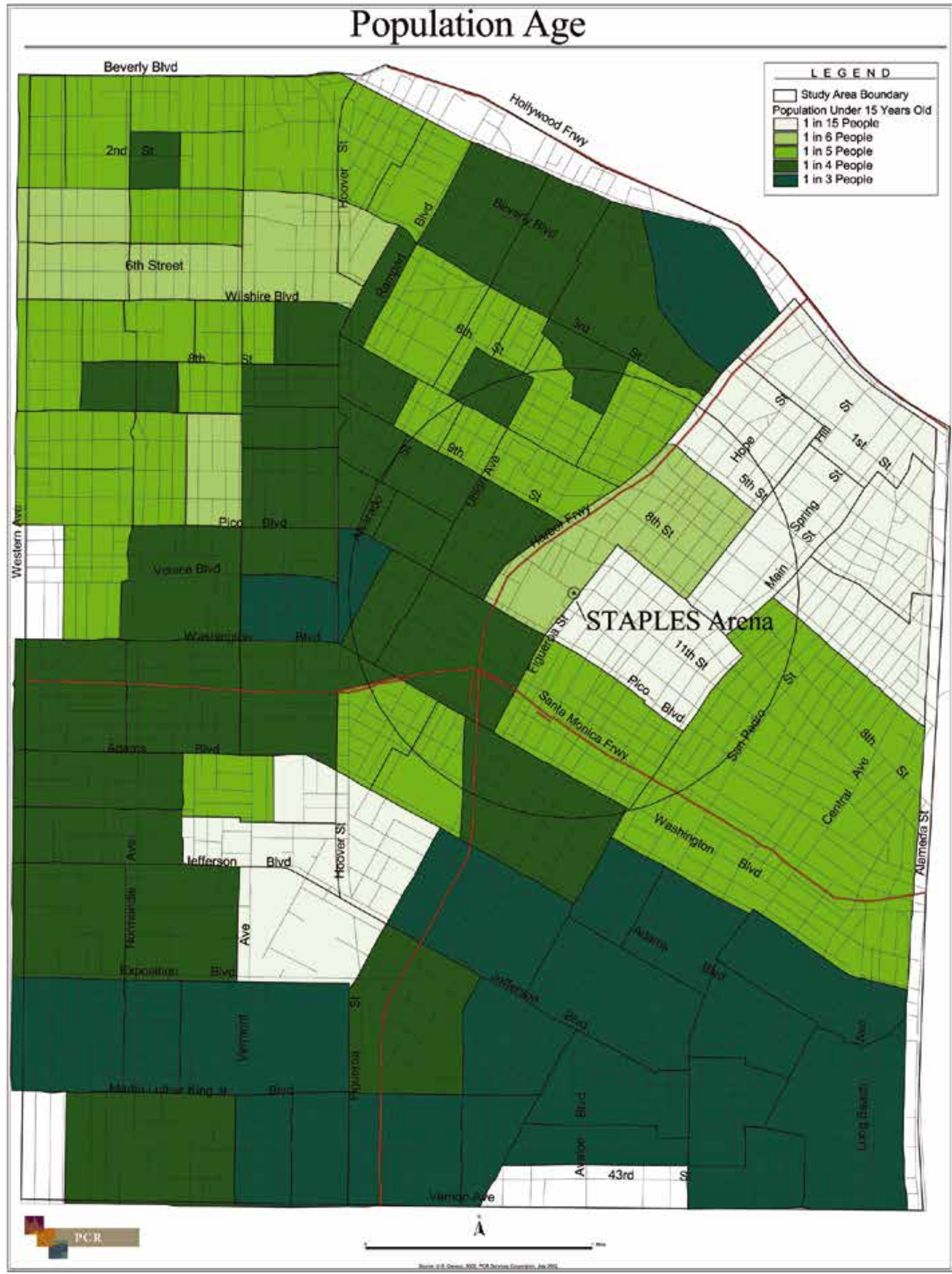


Figura 53:

Mapa elaborado a partir

do censo de 2000. Mapa

de densidades. Autor: PCR

consultants. Fonte: Parks and

Recreation Assessment Study STAPLES CENTER. Mia Lehrer + Associates.

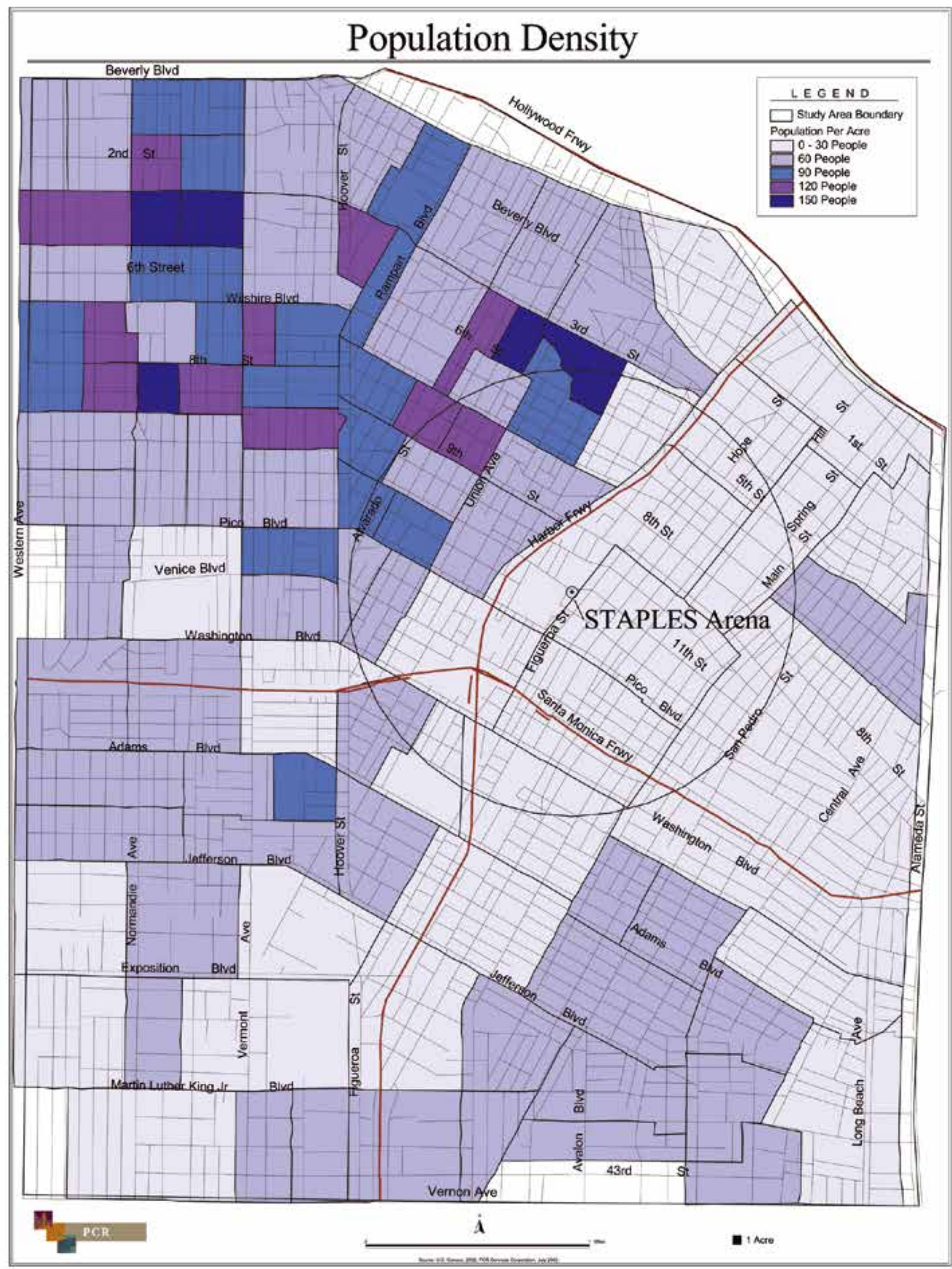


Figura 54:

Mapa elaborado a partir do censo de 2000. Concentração de população por renda. Autor: PCR consultants. Fonte: Parks and Recreation Assessment Study STAPLES CENTER. Mia Lehrer + Associates.

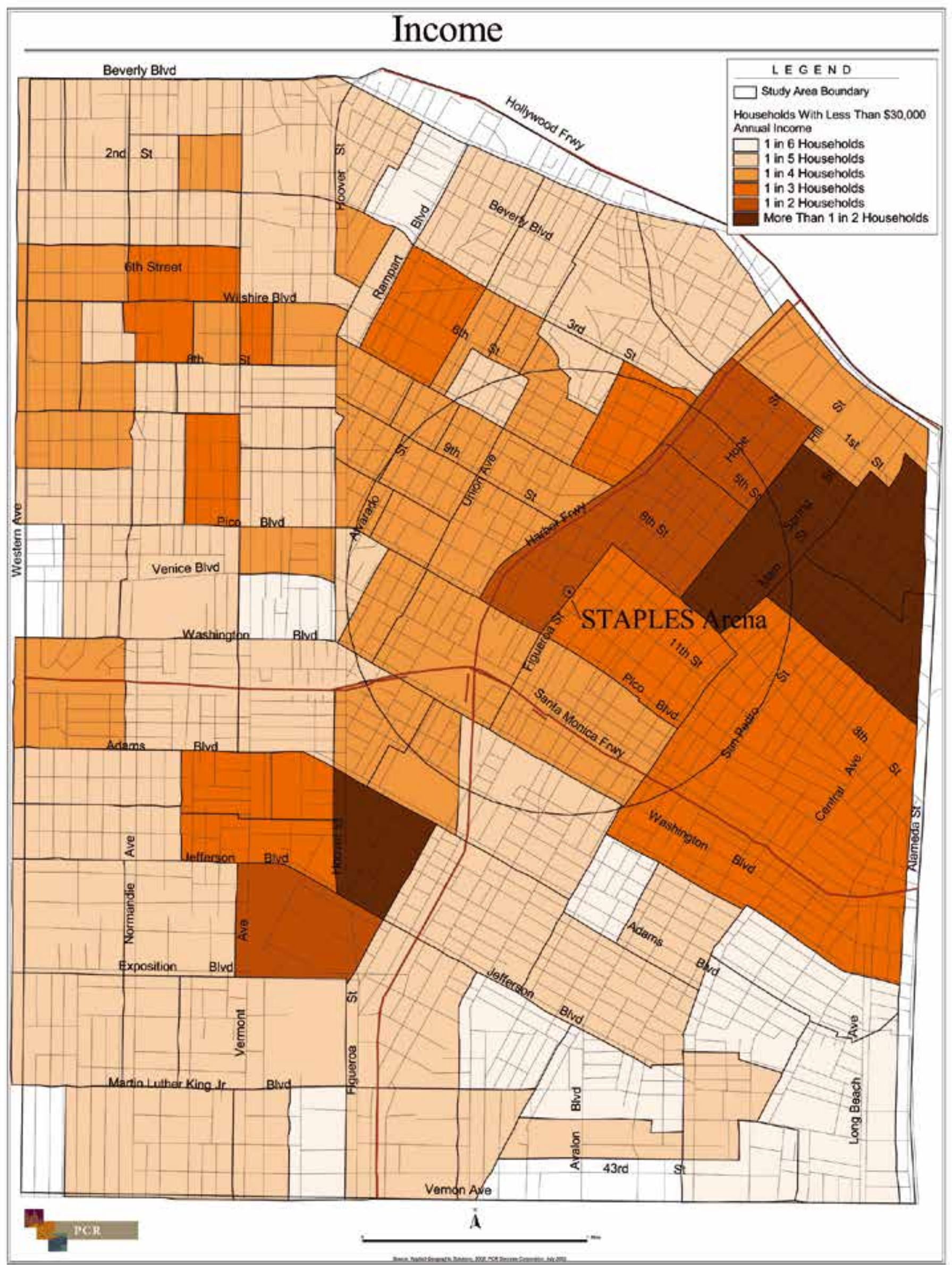

Capítulo 6 - O caso do AT\&T Park em São Francisco e da Arena STAPLES Center em Los Angeles. 
Figura 55:

Mapa elaborado a partir

do censo de 2000. Mapa

de prioridades. Autor: PCR consultants. Fonte: Parks and

Recreation Assessment Study STAPLES CENTER. Mia Lehrer + Associates.

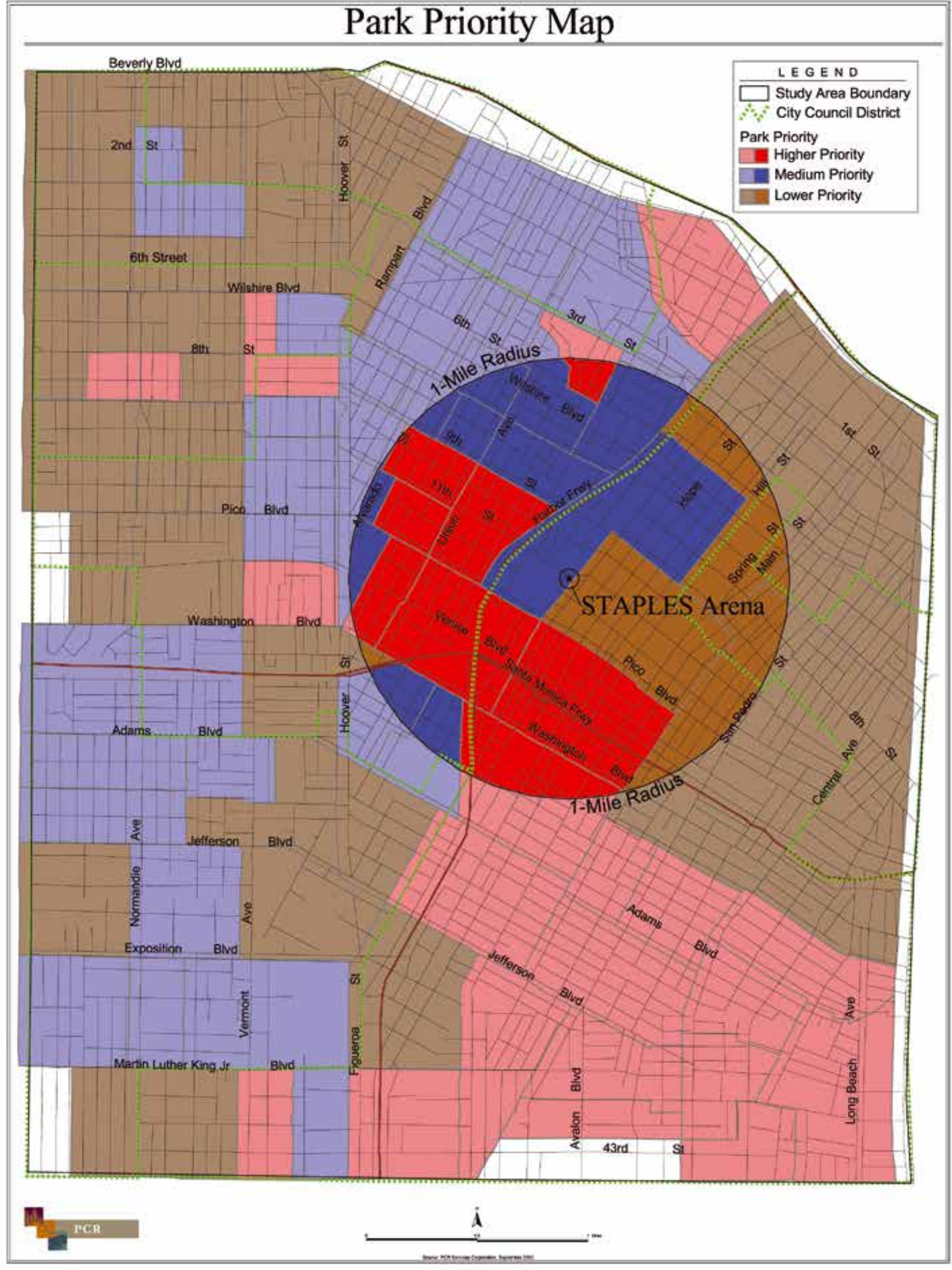

Capítulo 6 - O caso do AT\&T Park em São Francisco e da Arena STAPLES Center em Los Angeles. 
Nas oficinas de participação comunitária, os residentes eram solicitados a examinar fotos aéreas e mapas com dados demográficos e contribuir com suas opiniões a respeito dos locais mais adequados para receber novos equipamentos públicos. Os participantes elaboraram os seguintes critérios para a escolha do local de implantação dos novos parques:

- Localização dentro dos bairros predominantemente residenciais;

- Próximo a escolas;

- Em terrenos vagos ou estacionamentos para evitar gastos com aquisições caras e desapropriações;

- Em áreas carentes de parques existentes;

- A uma distância a pé de suas casas para se evitar outros modos de transporte;

- Proporcionar uma distribuição de áreas verdes equilibrada dentro de áreas densamente povoadas.

Figura 56: Arena STAPLES Center implantada na área central de Los Angeles. Fonte: Mia Lehrer + Associates.

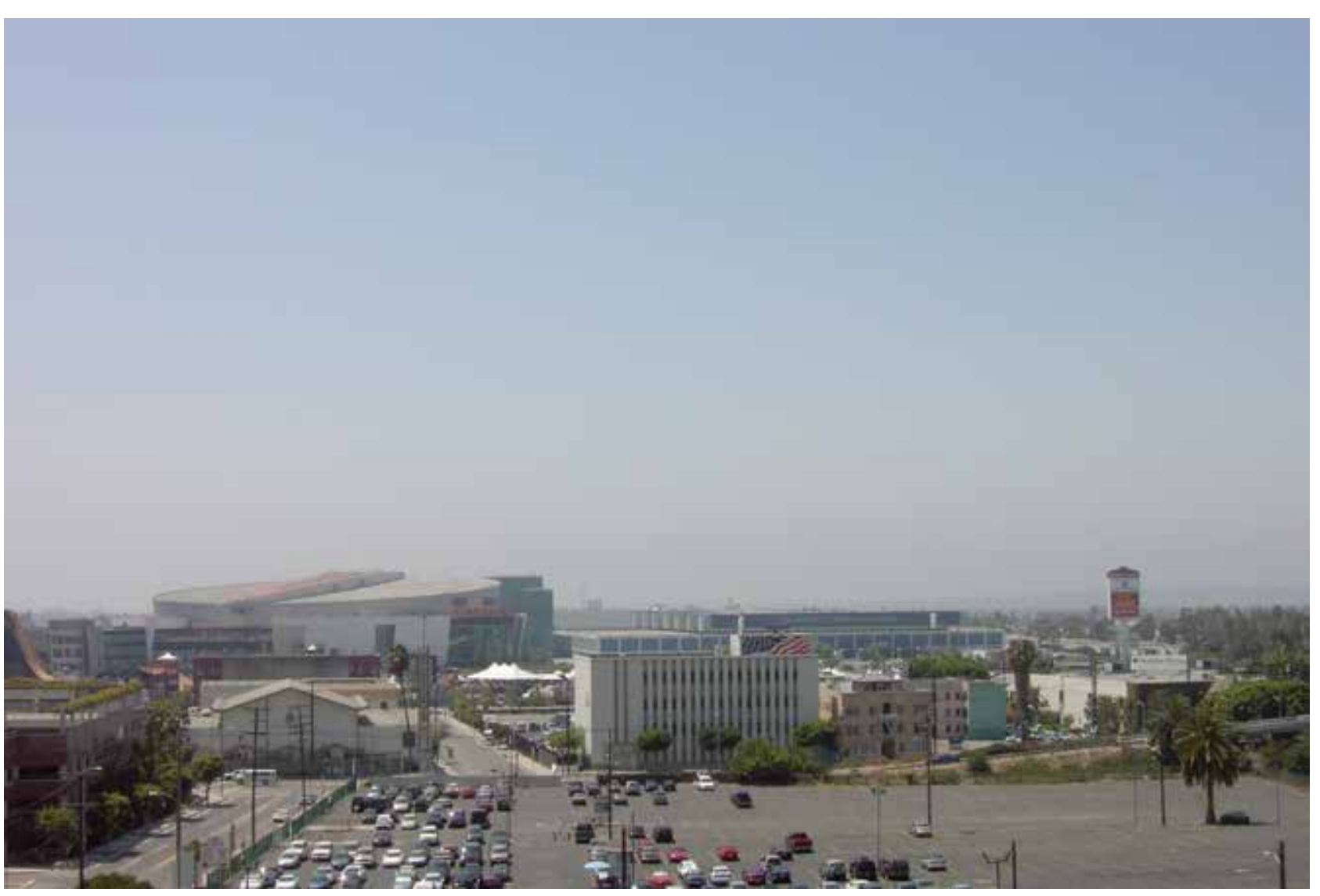


Figura 57:

Mapa com ilustração das áreas verdes desejadas pela comunidade sobre foto aérea do Google. Fonte: Parks and Recreation Assessment Study STAPLES Center. Mia Lehrer + Associates.

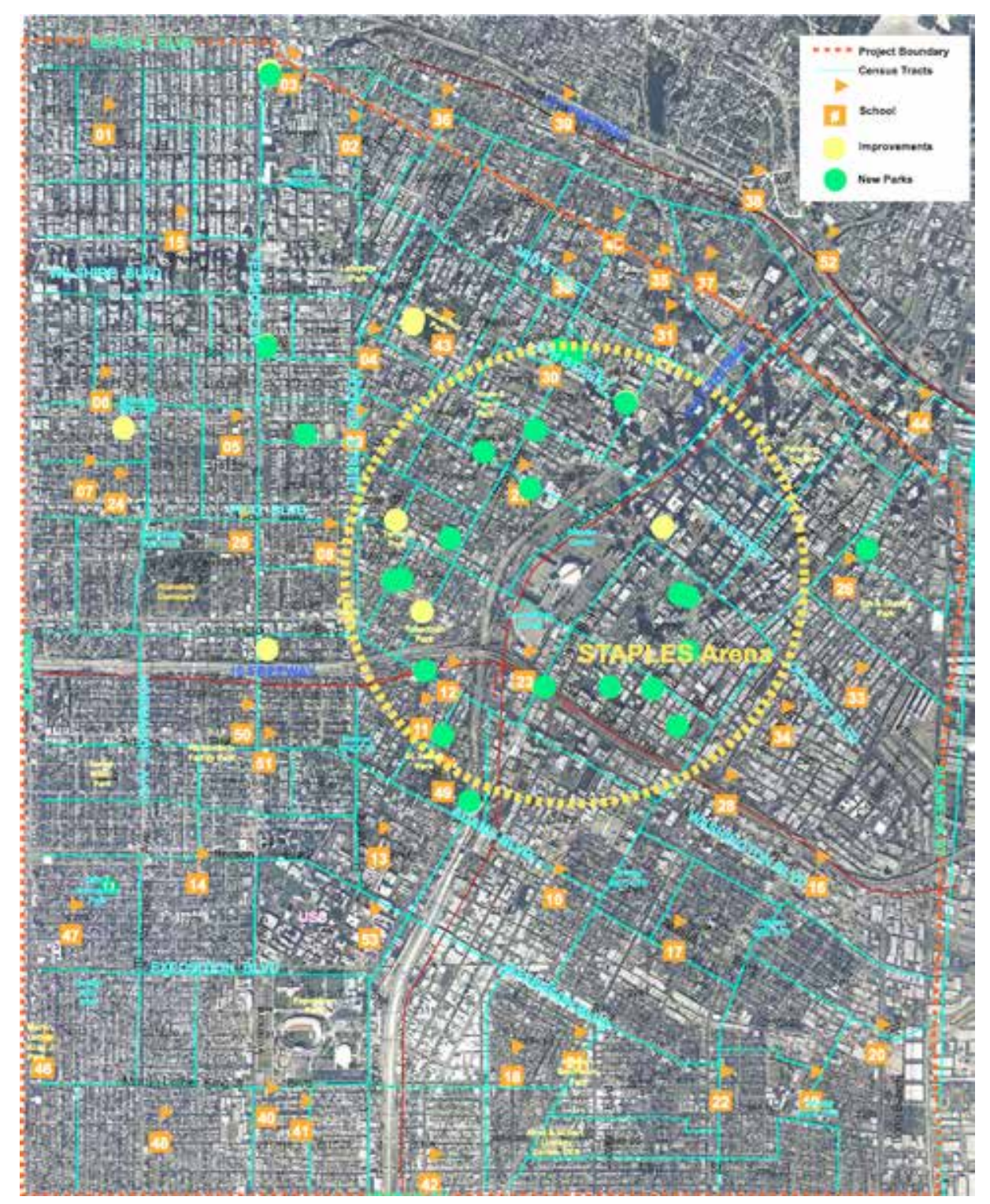

A equipe de projeto entrou em contato com o Departamento de Parques e Recreação da Prefeitura de Los Angeles, a Agência de Desenvolvimento (CRA) e a Secretaria de Educação (LAUSD), para obter informações sobre projetos já planejados para a área de 1,6 km do centro da arena. Embora não houvesse planos para implantação de novos parques na área, a Prefeitura dispunha de recursos para a melhoria dos equipamentos públicos existentes para investimento no curto e longo prazo, além de um convênio com o Departamento de Polícia para melhorar a segurança dos parques existentes. Parte da área de estudo faz parte do Projeto de Revitalização do City Center e um terreno em potencial foi localizado pela Agência de Desenvolvimento CRA para a instalação de um novo parque dentro da área de estudo na esquina das ruas Venice e Hope. 
A Secretaria de Educação planejou a implantação de uma série de novas escolas dentro da área de estudo. Potencialmente as escolas poderiam abrir as suas áreas de esporte e lazer para a comunidade durante os finais de semana e, desta forma, serem incorporadas como áreas de investimento. No entanto, haviam desafios a serem enfrentados para a viabilidade deste uso conjunto como a responsabilidade pela gestão e a zeladoria dos espaços fora do período escolar.

\subsubsection{PROTÓTIPOS PROPOSTOS PARA FUTUROS ESPAÇOS PÚBLICOS NA ÁREA DE INTERVENÇÃO}

A equipe de projeto desenvolveu uma série de protótipos em terrenos hipotéticos para ilustrar o potencial das áreas subutilizadas dentro da área de estudo, bem como propiciar a simulação de custos de implantação.

\subsubsection{Protótipo 1 - Pequeno parque}

O programa do pequeno parque inclui área de playground, um jardim comunitário, um espelho d'água, áreas de estar e um espaço para apresentações artísticas ao ar livre. A área necessária para implantação deste programa foi calculada em $420 \mathrm{~m}^{2}$ e o custo estimado para sua execução variava de cento e cinquenta mil a cento e setenta e cinco mil dólares.

Figura 58: Imagem ilustrativa do pequeno parque. Fonte: Parks and Recreation Assessment Study STAPLES Center. Mia Lehrer + Associates.

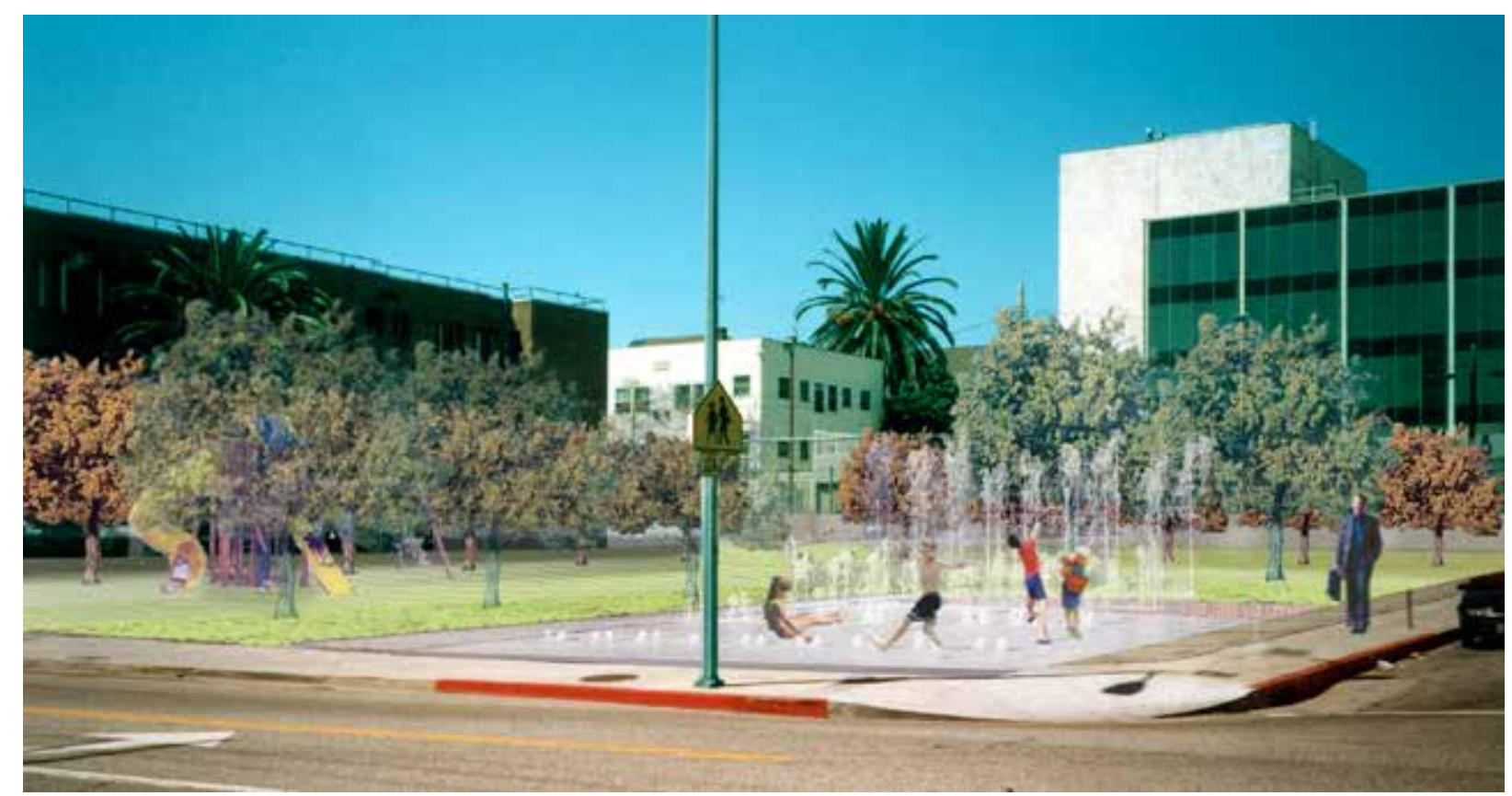




\subsubsection{Protótipo 2 - Pequeno parque em viela}

Estudou-se a transformação de vielas de serviço também em pequenos parques de área aproximada de $800 \mathrm{~m}^{2}$. O programa poderia incluir áreas de playground, fonte, áreas de estar, sanitários públicos, quadra de basquete e áreas de piquenique. O custo estimado para este protótipo foi de duzentos mil a duzentos e cinquenta mil dólares.

Figura 59:

Viela de serviço antes da intervenção. Fonte: Mia Lehrer + Associates.

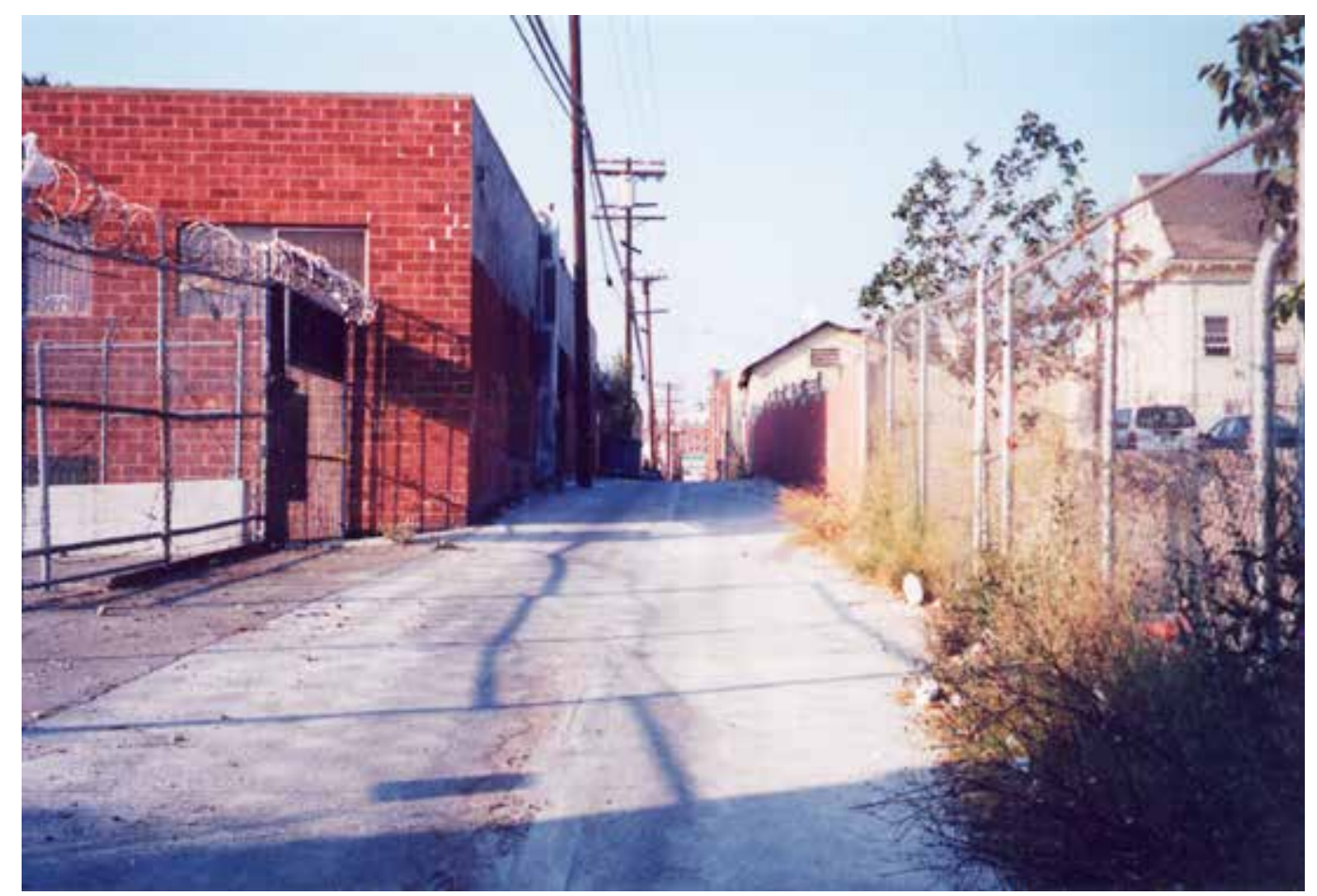

Figura 60: Vila após a intervenção. Fonte: Mia Lehrer + Associates.

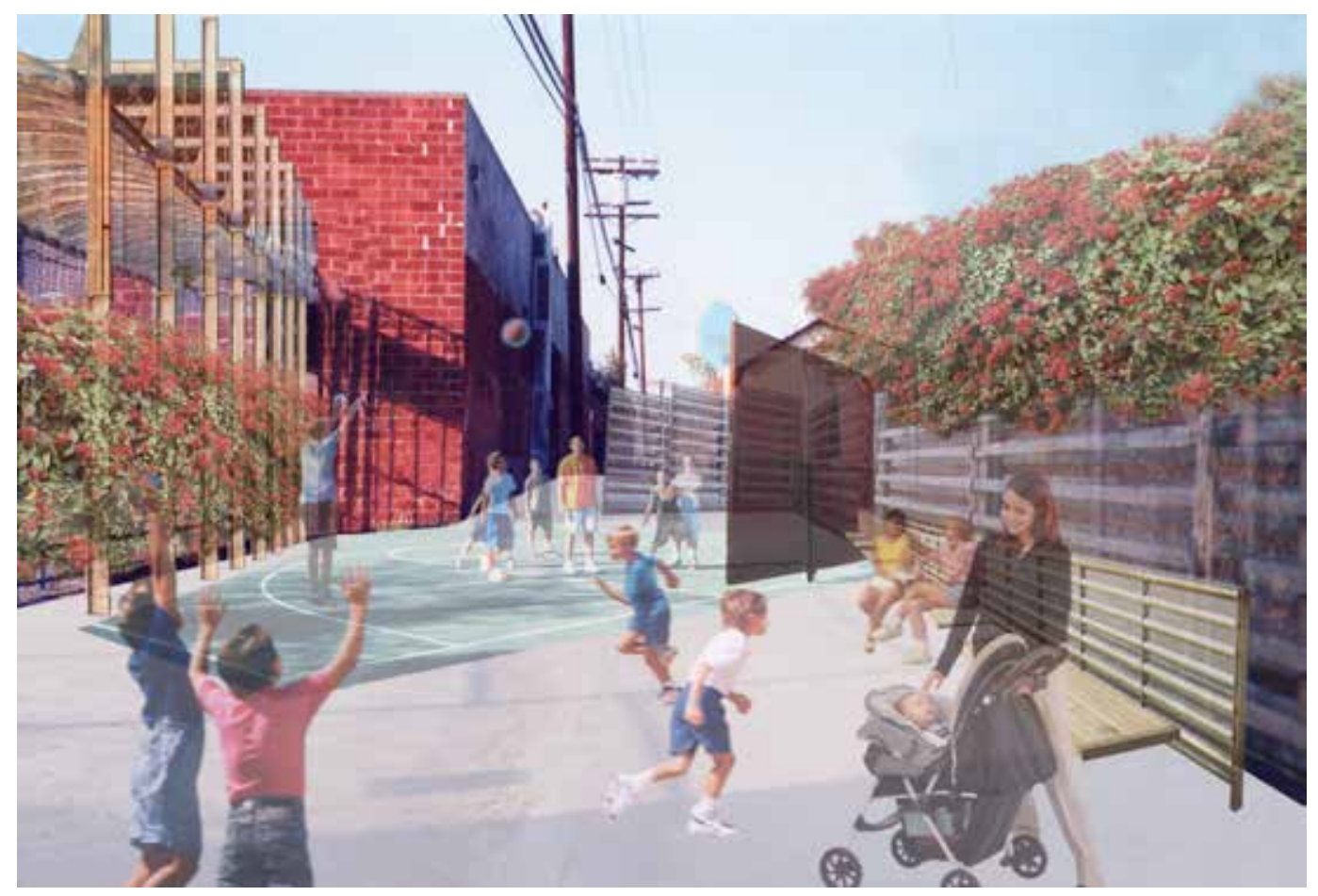




\subsubsection{Protótipo 3 - Parque médio}

Outro protótipo estudado foi a implantação de parques médios em áreas de estacionamento subutilizadas. A área necessária para este protótipo foi calculada em 3.000 $\mathrm{m}^{2}$, com o custo aproximado de duzentos mil a duzentos e cinquenta mil dólares. O programa deste protótipo inclui um campo de futebol, áreas de estar, sanitários públicos e áreas de piquenique.

Figura 61:

Área de estacionamento subutilizada antes da intervenção. Fonte: Mia Lehrer + Associates.

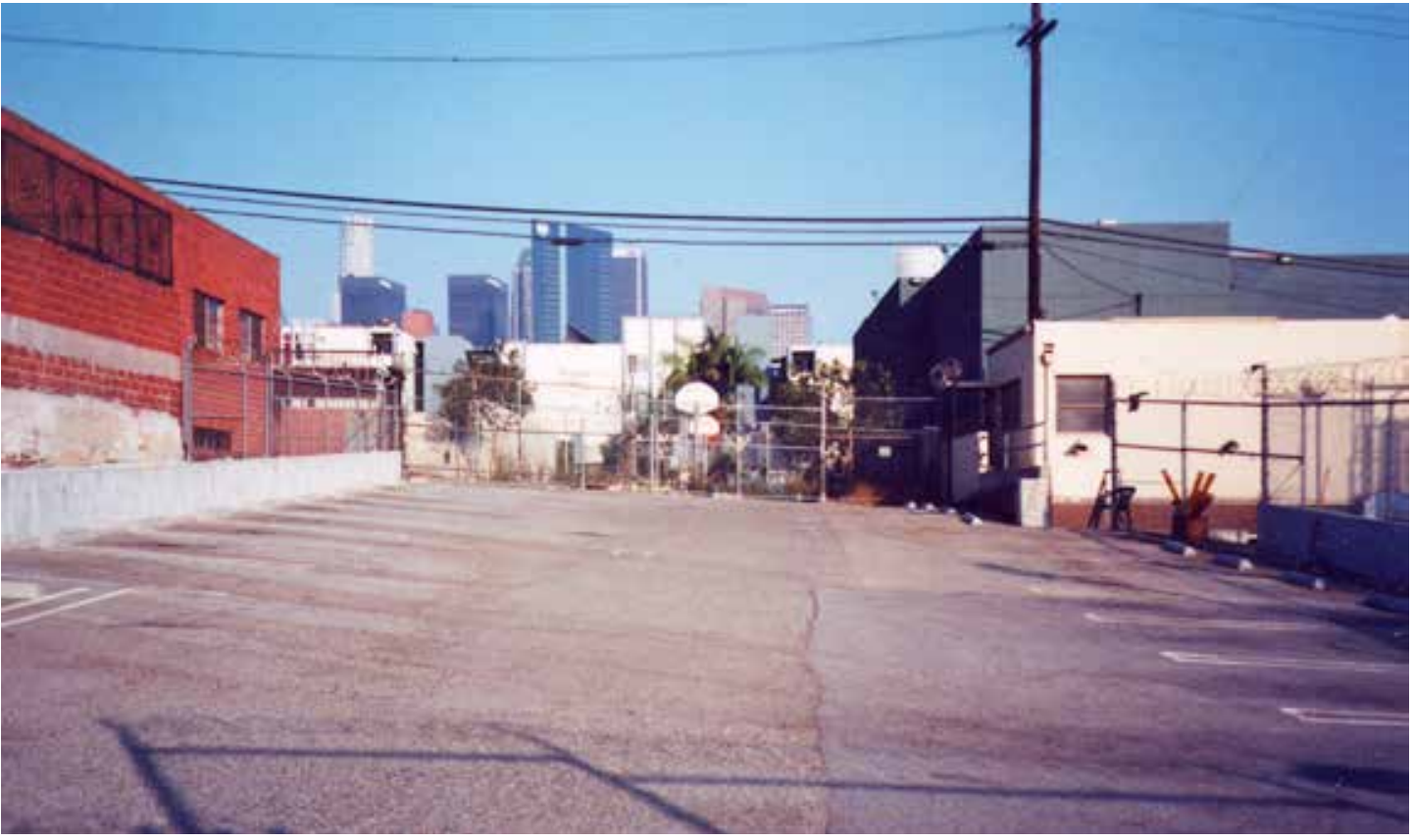

Figura 62:

Parque médio implantado em área de estacionamento subutilizada. Fonte: Mia Lehrer + Associates.

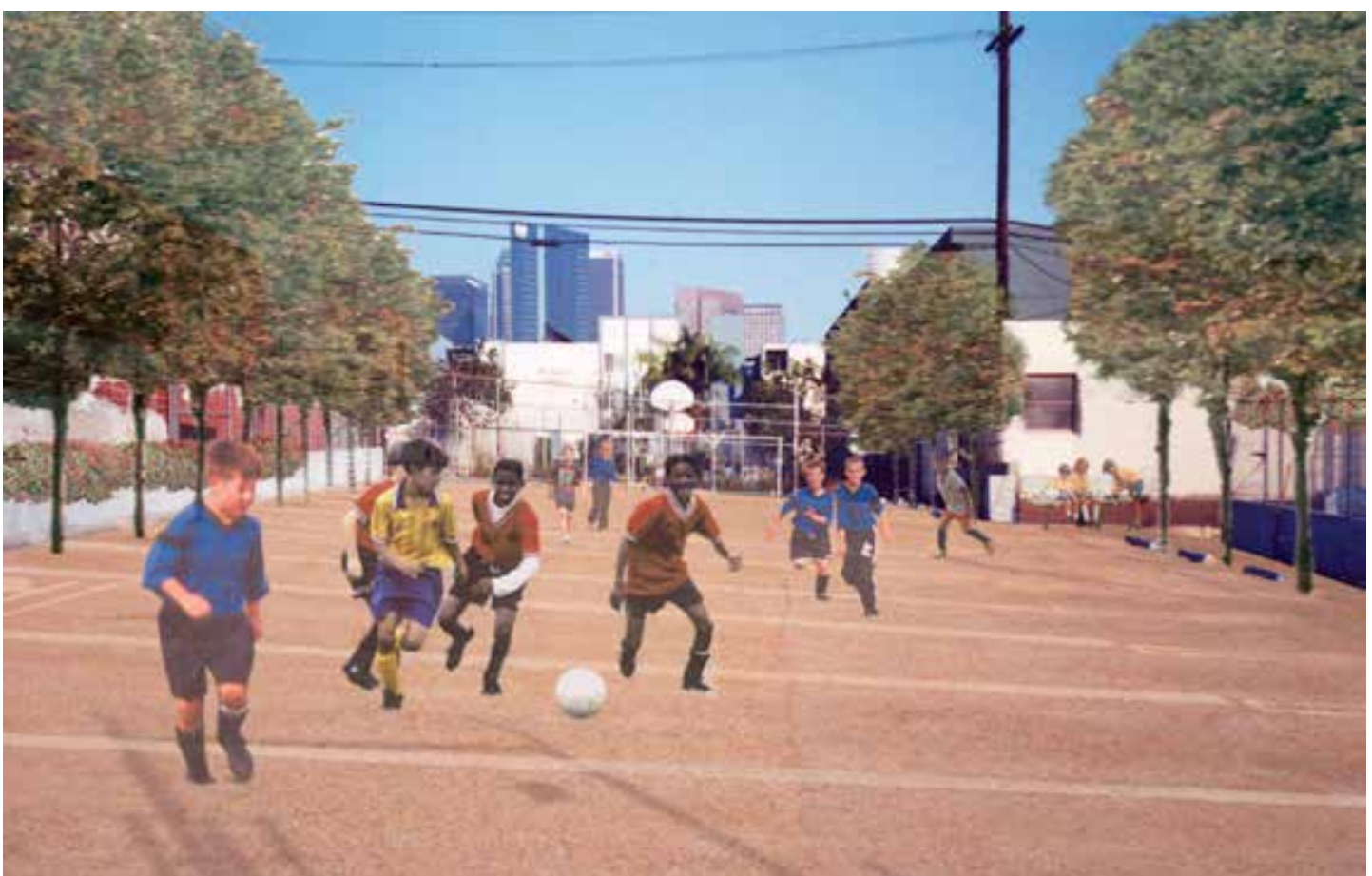


Figura 63: Área potencial para implantação de um parque grande antes da intervenção. Fonte: Mia Lehrer + Associates.

\subsubsection{Protótipo 4 - Parque grande}

O último protótipo proposto foi para áreas maiores, com cerca de $6.000 \mathrm{~m}^{2}$ e custo de implantação calculado em oitocentos mil dólares, sem o centro comunitário e de dois milhões, com o centro comunitário. O programa inclui um campo de futebol, dois playgrounds, duas quadras de basquete, um espelho d'água, sanitários públicos, áreas de estar, campo de softball, centro comunitário e áreas de piquenique.

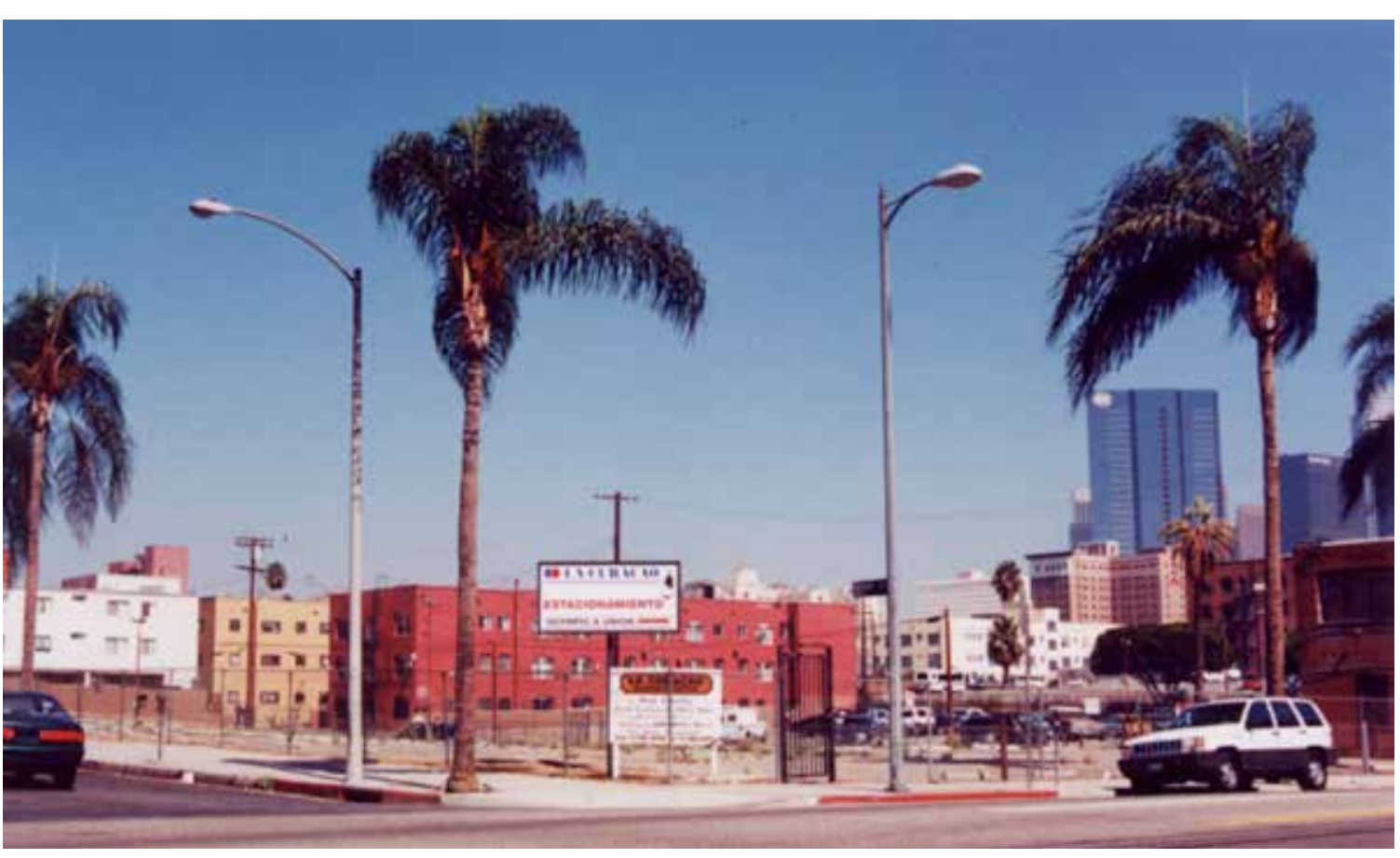

Figura 64:

Parque grande implantado em área subutilizada dentro da área de estudo.

Fonte: Mia Lehrer + Associates.

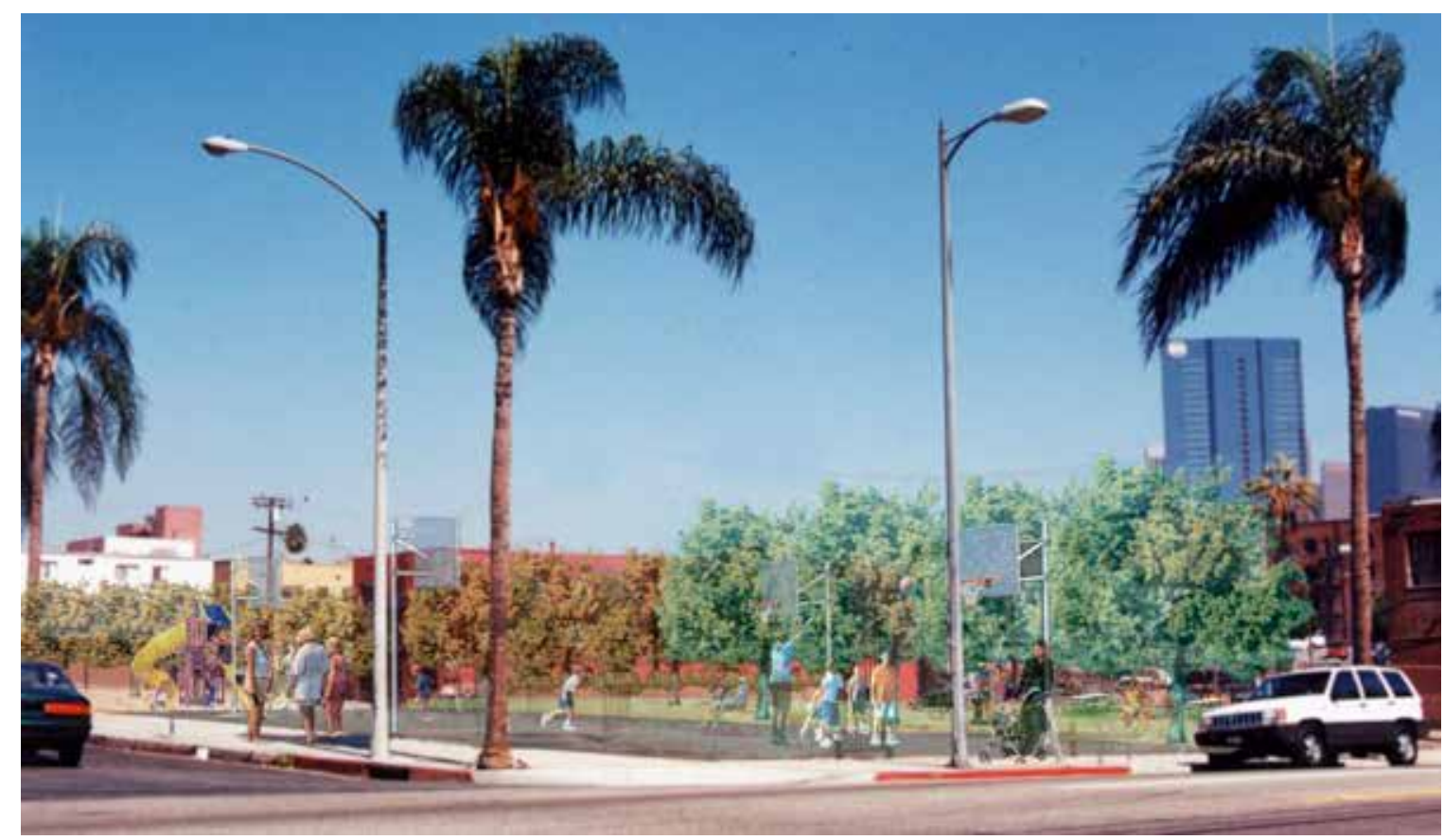


O estudo identificou centros comunitários que poderiam receber o investimento para reformas e espaços públicos existentes que poderiam ser melhorados e/ou ampliados.

Em conclusão, verificou-se que a área de estudo possuía várias carências e que o recurso reservado para o investimento não era suficiente para suprir todas elas, no entanto, o estudo foi usado como instrumento para arrecadação de fundos federais e estaduais para implantação de outros projetos.

A arena promove até hoje a dinamização do tecido urbano de seu entorno e atraiu a atenção do poder público e da iniciativa privada para o potencial da área central da cidade de Los Angeles, anteriormente em processo de degradação. Com o Plano de Revitalização do Rio Los Angeles, em fase de implantação, há um grande potencial para a expansão de uma infraestrutura verde em toda a área central da cidade (figura 65).

A população de baixa renda permaneceu no local e é beneficiada pelas políticas públicas de contrapartidas geradas pela intervenção crescente do mercado privado. Terá a Arena Corinthians em Itaquera o mesmo potencial? 


\section{ARENA STAPLES - LOS ANGELES, CALIFORNIA, EUA}

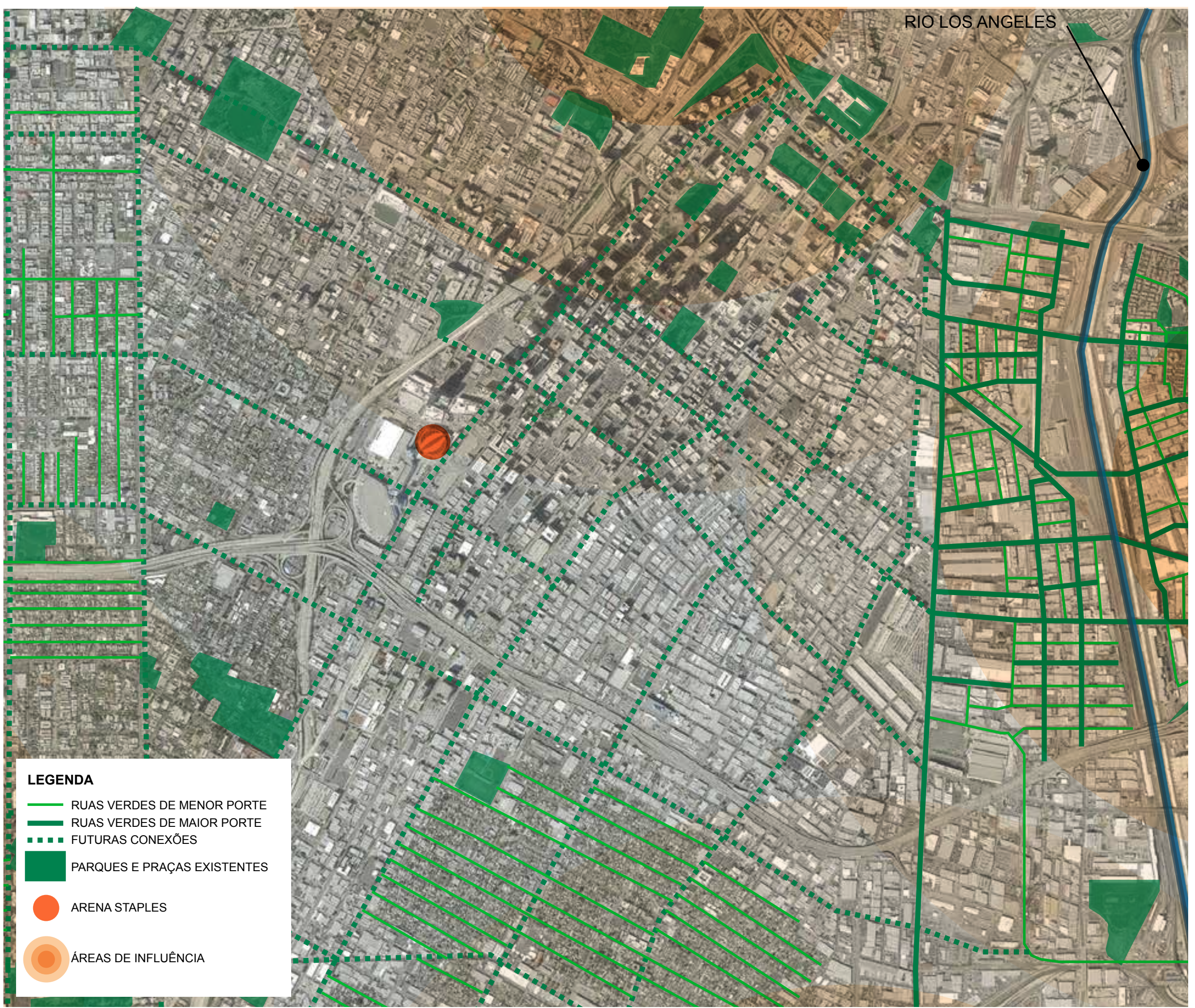

ESCALA 1:2500

Fiqura 65: Espaços verdes públicos no entorno da Arena Staples e parte da área da influência do Rio Los Angeles. Mapeamento: Patrícia Akinaga. Base: Google Earth, 2013. 


\section{CAPÍTULO 7 \\ 0 IMPACTO AMBIENTAL DO ESTÁDIO SOCCER CITY DA AFRICA DO SUL}

7.1 O ESTÁDIO SOCCER CITY E OS PROJETOS PÚBLICOS COMO LEGADO

7.2 A REGIÃO F DE JOHANNESBURGO 


\subsection{O ESTÁDIO SOCCER CITY E OS PROJETOS PÚBLICOS COMO LEGADO}

O estádio Soccer City localiza-se na cidade de Johannesburgo, no bairro de Nasrec na área de Soweto, África do Sul. Ele também é conhecido como de FNB, First National Bank Stadium. O estádio tem capacidade para 94.736 pessoas, no entanto, durante a Copa do Mundo da FIFA de 2010, esta capacidade foi reduzida para 84.490 para o público, devido aos assentos reservados para a imprensa e para convidados.

O estádio foi inaugurado em 1989 e foi palco do primeiro discurso de Nelson Mandela após sua libertação da prisão. Em 2009, a fim de abrigar os jogos da Copa, foi inteiramente renovado e ampliado e seu entorno sofreu alterações significativas tornando-se uma grande área desocupada (figura 66).

O estádio pertence à Prefeitura de Johannesburgo e é gerenciado pela empresa Stadium Management South Africa. O projeto da reforma e expansão foi do escritório Boogertman \& Partners e do escritório Populous (HOK Sports). Na reforma, o estádio recebeu uma "nova pele" inspirada pela forma de uma cesta africana tradicional composta por um mosaico de cores em tons de terra. 


\section{ARENA SOCCER CITY - JOHANNESBURG, AFRICA DO SUL}

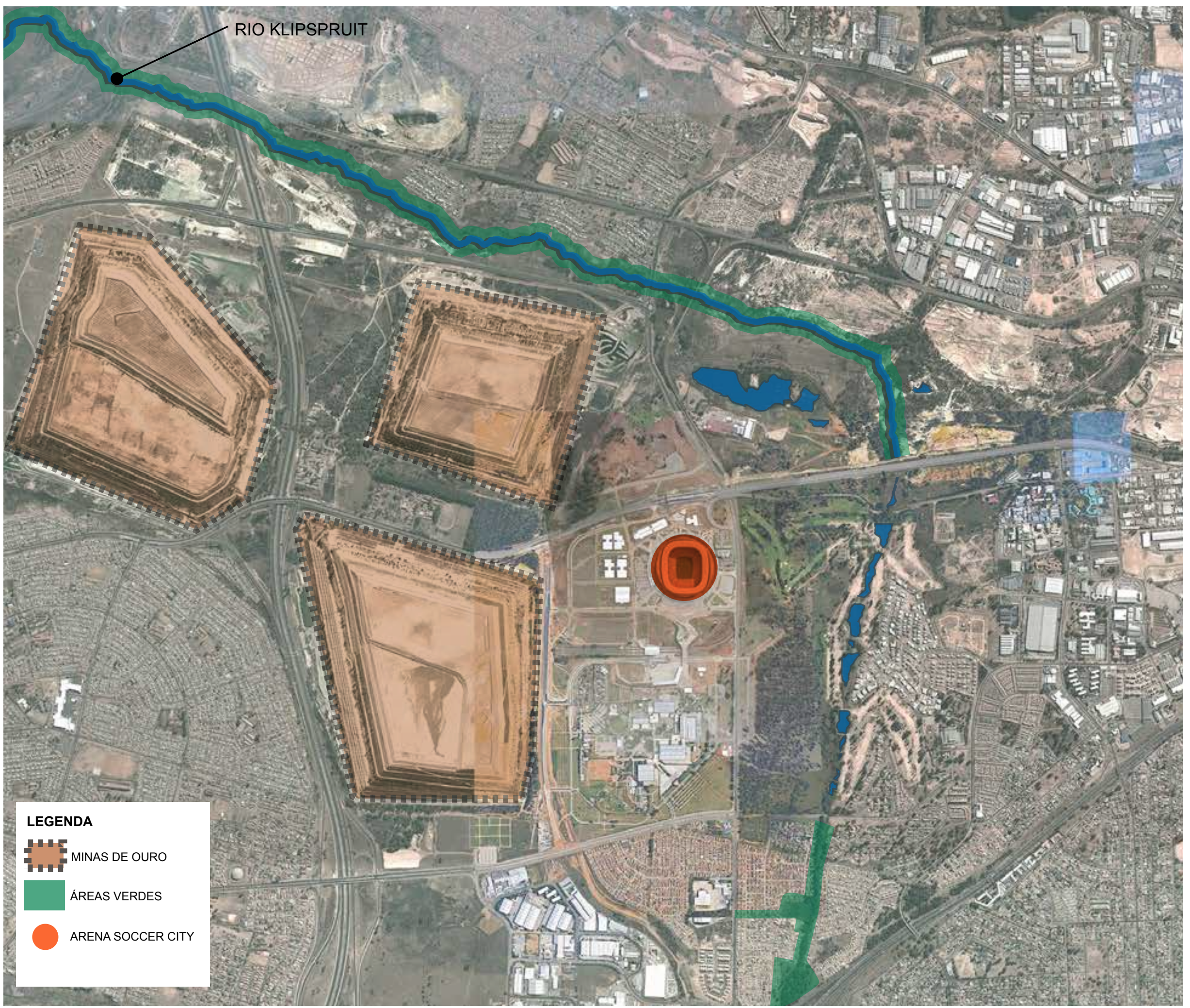

ESCALA 1:2500 
Figura 67: Estádio Soccer City, fachada principal. Foto: Patrícia Akinaga, Janeiro de 2013.

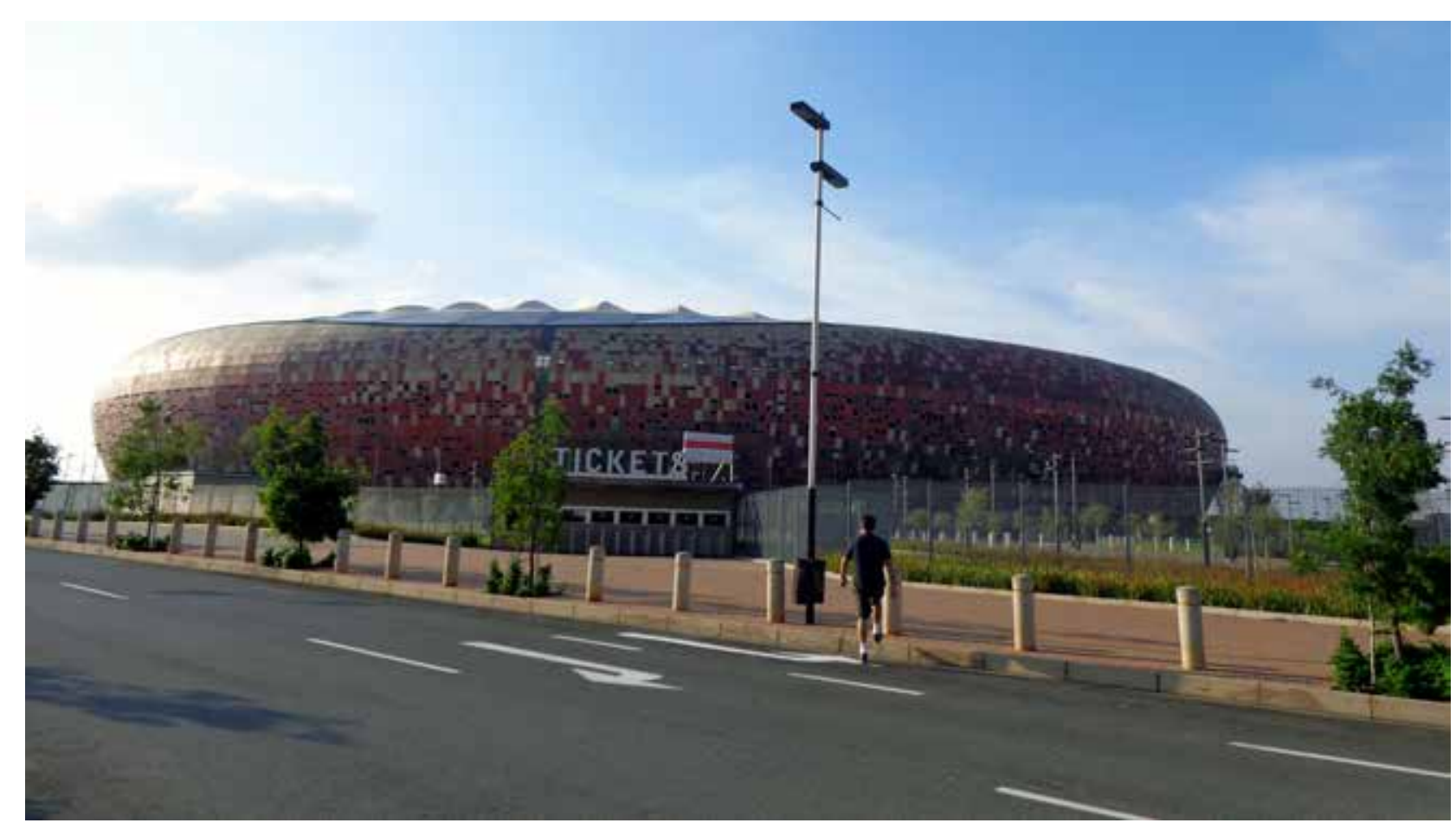

Como legado da Copa do Mundo, segundo a Prefeitura de Johannesburgo, foram identificados vários projetos para estimular o desenvolvimento econômico e social em áreas anteriormente negligenciadas pelo poder público, com o objetivo de capacitar a comunidade e criar empregos. Sete projetos foram propostos como: a instalação de mobiliário urbano, a reforma de campos de futebol existentes nos bairros, a construção de um centro esportivo, a reforma do albergue Diepkloof, a implantação de áreas verdes ao longo do rio Klipspruit, a implantação do sistema de ônibus expressos BRT (Bus Rapid Transit) e a construção de um teatro em Soweto.

Com o projeto de implantação de áreas verdes ao longo do rio Klipspruit e seus tributários surgirão outras oportunidades ainda em estudo, que incluem os parques Lenasia Vlei Wetland Park, Orlando WestWetland Park, Mapetla Wetland Park e os corredores ecológicos dos alagados Kliptown.

Segundo os objetivos da Prefeitura, as áreas verdes do rio Klipspruit somarão 120 quilômetros de reabilitação ecológica e terão impacto em toda Soweto, com melhoria da qualidade da água através da implantação de estações de tratamento e da rede elétrica, com efeitos positivos sobre a qualidade ambiental, minimizando o desperdício da água e a poluição dos rios de Soweto por águas negras. 
1 Descrição extraída do website oficial da Prefeitura de Johannesburgo. Fonte: <www.joburg.org.za> Acesso em: 18 nov. 2013
O sistema de transporte implantado SPTN (Strategic Public Transport Network), Rede Estratégica de Transporte Público foi substituído pelo sistema de BRT para a Copa de 2010. Houve o aproveitamento dos dados de demanda da SPTN para dimensionamento e projeto do BRT. Em visita à cidade em 2013 realizada pela autora, foi verificada a implantação parcial de corredores de ônibus com plataformas à esquerda da via e estações para aquisição de bilhetes antes do embarque.

\subsection{A REGIÃO F DE JOHANNESBURGO}

O estádio Soccer City localiza-se na denominada Região F do subúrbio de Johannesburgo. Seus limites constituem-se do Killamey Ridge ao norte, com as Regiões E de Houghton e Orange Grove e B, Parktown, a leste com a Municipalidade Metropolitana Ekurhuleni, ao sul com o Rio Klip e a oeste com as Regiões D, Soweto e G, Joburg Sul.

Estas áreas são predominantemente residenciais e de baixa densidade a leste do centro da cidade. O limite sul da Região F possui a parte sudeste da linha de metrô e é comumente denominada de Johannesburgo Sul. Ao norte, encontram-se a via expressa M2 e o cinturão de mineração, elementos importantes da paisagem da cidade. A Região F constitui-se de vários bairros suburbanos, dentre eles, o bairro de Nasrec, onde se localiza o estádio Soccer City.

A Região $\mathrm{F}$ é considerada uma área de contrastes. ${ }^{1} \mathrm{~A}$ paisagem é marcada por áreas residenciais degradadas como a do bairro de Bertrams e de áreas comerciais consolidadas como a de Braamfontein, em contraste com os bairros das classes médias e altas de Glenvista, Mulbarton e Bassonia no limite sul da região.

A área central da região tem muita vitalidade e estima-se que cerca de um milhão de pessoas em trânsito passem por ela diariamente. Funciona como uma centralidade regional para compras de residentes do entorno de Johannesburgo e até de visitantes de outros países africanos.

Devido a sua infraestrutura, a Região F é bem integrada com as áreas de seu entorno, não só pelo transporte público através do BRT e do metrô, mas também através de vias arteriais 


\footnotetext{
2 Extraído do website oficial da Prefeitura de Johannesburgo. Fonte: $<$ www.joburg.org.za>. Acesso em: 18 nov. 2013.
}

importantes que lá se originam e se dirigem a outras partes da cidade. Há também terminais de ônibus, pontos de táxi e a linha de trem.

Apesar de existirem, os pequenos parques de vizinhança não suprem a necessidade da Região por mais áreas verdes. O principal parque é o Joubert, onde se localiza a galeria de arte de Johannesburgo.

A Região F possui população estimada em 433.054 habitantes, segundo o censo de $2001^{2}$. $\mathrm{Na}$ área central há predominância da comunidade negra de baixa renda, em contraste com a área ao sul, onde $66 \%$ da população é branca, com 38\% de jovens com menos de 25 anos. A população nesta área está crescendo, atraída por melhores empreendimentos habitacionais, valor da terra, equipamentos públicos e acesso conveniente aos centros de emprego.

Um dos objetivos da Prefeitura para a região é aumentar e sustentar o investimento privado nas áreas mais desfavorecidas a fim de promover o aumento do valor da terra. Os pontos principais do plano de revitalização da região incluem a revitalização de edifícios degradados e infraestrutura deteriorada; a melhoria da segurança pública; a zeladoria de espaços públicos atualmente abandonados; o resgate do valor das propriedades; a implantação de programas habitacionais para reduzir a ocupação irregular, as invasões de terra e edifícios vagos e atenção à presença de imigrantes e a tendência de xenofobia associada à imigração.

$\mathrm{Na}$ área sul da Região, o plano atualmente visa focar nas questões ambientais, como a poluição proveniente das áreas de mineração através da poeira e das águas de superfície; na segurança pública e nas áreas subutilizadas do entorno do Soccer City, em Nasrec. 
Figura 68:

Via de acesso principal ao estádio com vários terrenos

vagos em ambos os lados.

Foto: Patrícia Akinaga, Janeiro

de 2013

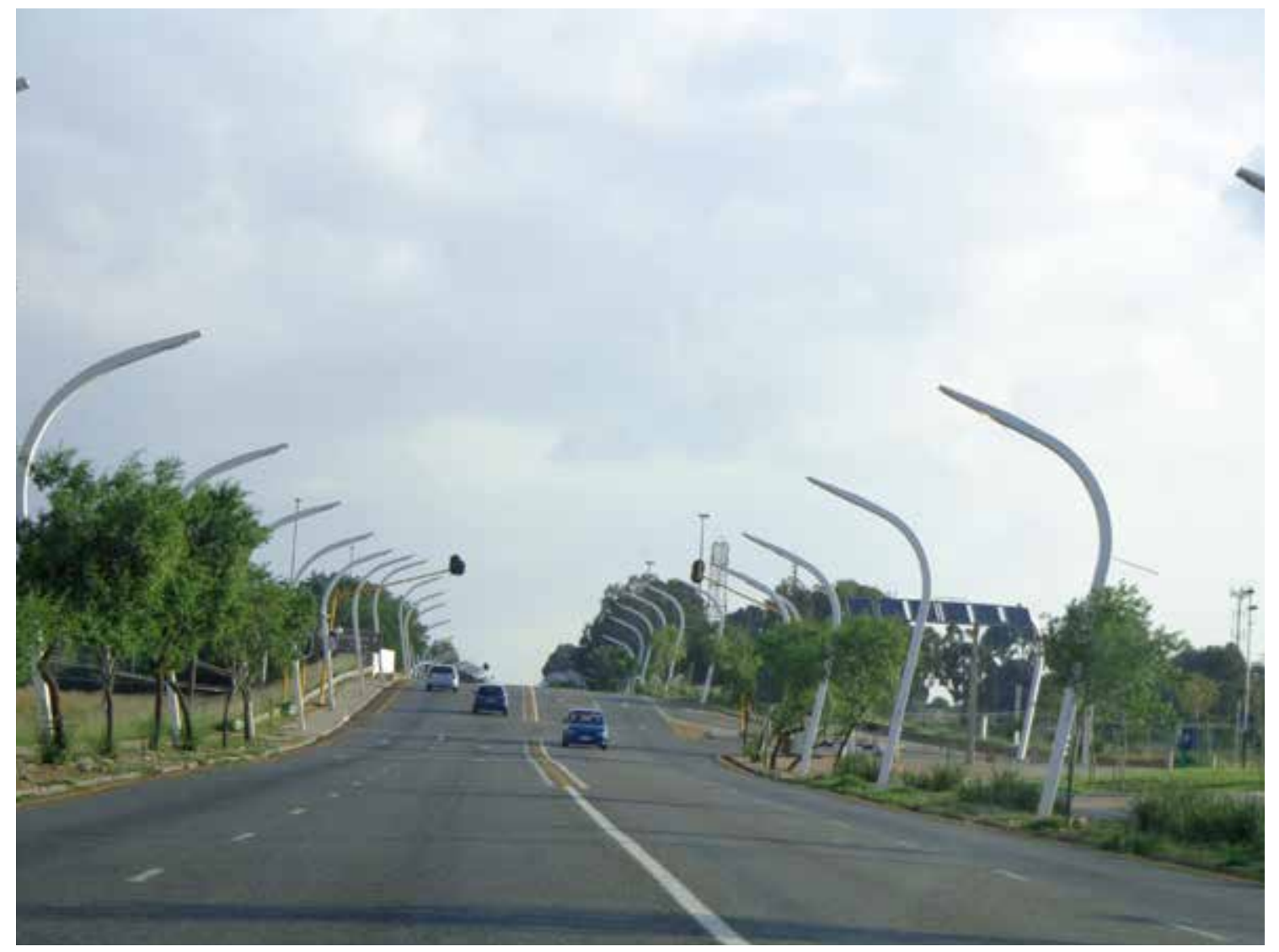

Figura 69:

Terreno vago no entorno do

Soccer City.

Foto: Patrícia Akinaga, Janeiro

de 2013.

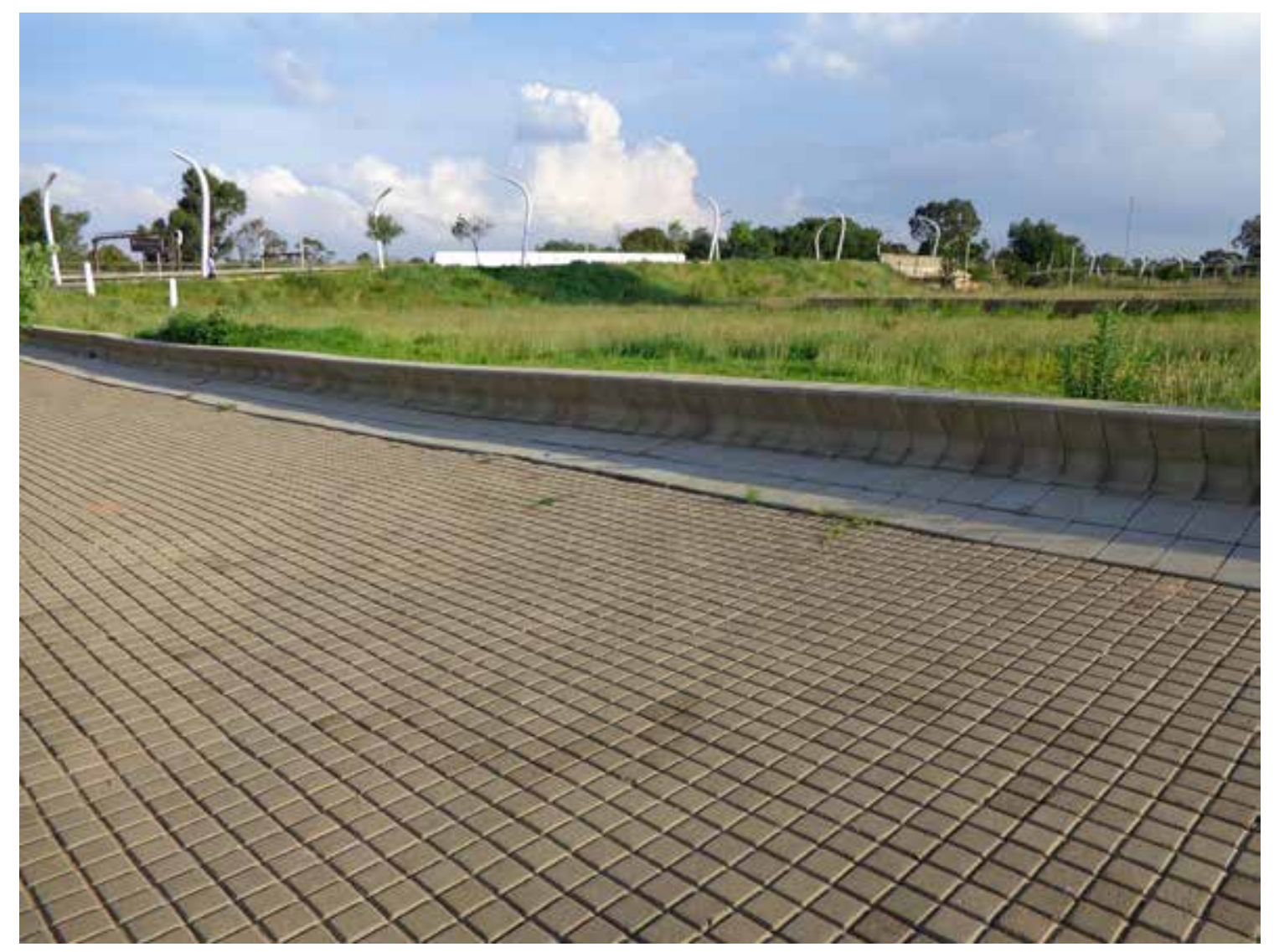

Capítulo 7 - O impacto ambiental do estádio Soccer City da África do Sul. 
Figura 70:

Acesso principal ao estádio Soccer City, entorno sem

desenvolvimento.

Foto: Patrícia Akinaga,

Janeiro de 2013.

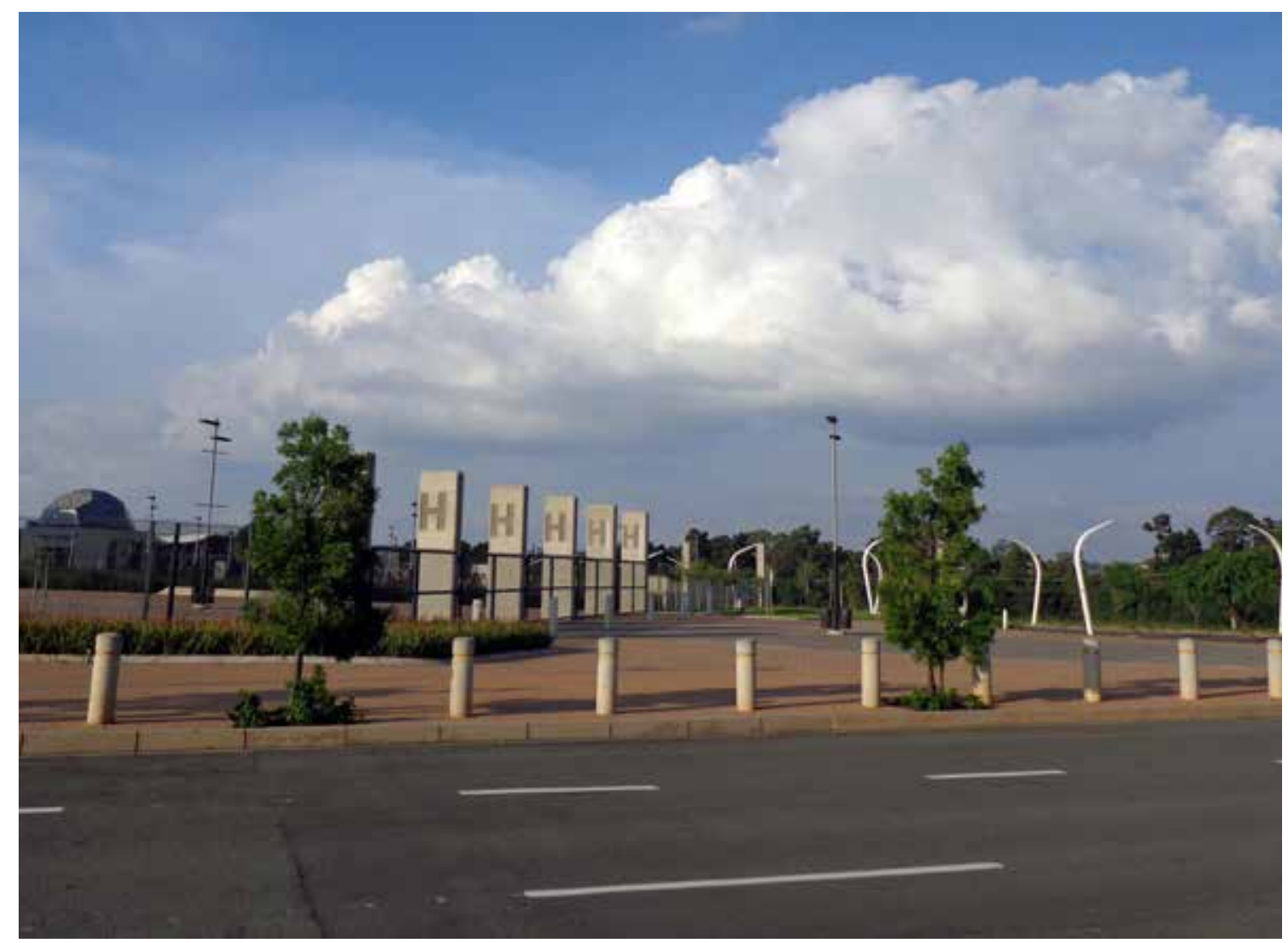

Figura 71:

Totem de sinalização da Copa ainda presente no local em

terreno vago.

Foto: Patrícia Akinaga, Janeiro de 2013.

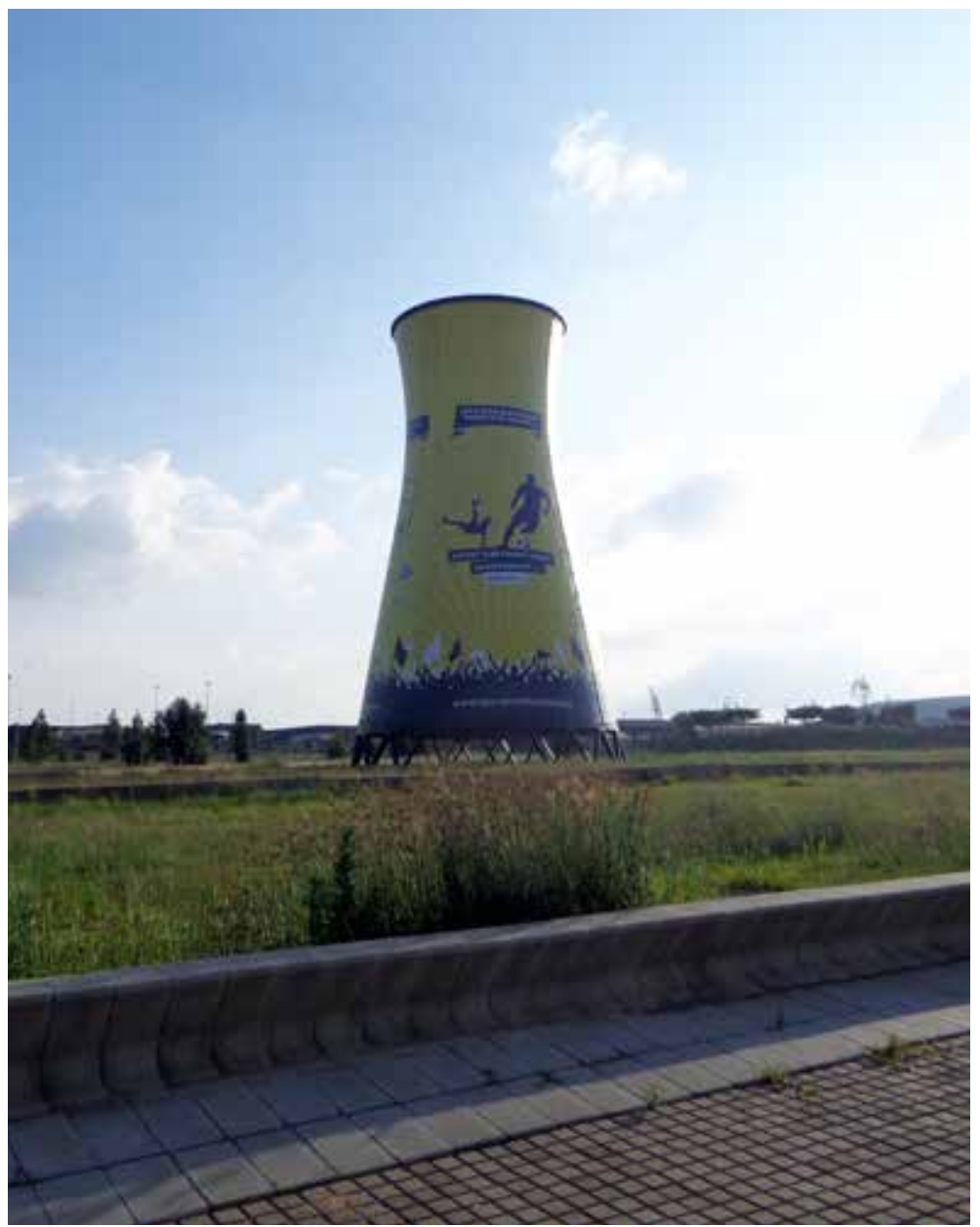



na área da vizinhança do estádio Soccer City. Disponível em: $<$ http://wetlands.sanbi.org/ gumboot_article.php?id=169>. Acesso em: 20 de Agosto de 2013.
O potencial para transformação existe e com uma ação articulada no poder público, ela pode acontecer. Muito se investiu nos estádios em atendimento às exigências da FIFA para a realização da Copa do Mundo na África do Sul. O que se vê, é uma série de equipamentos esportivos de grande escala com pouco uso por todo o país. Os estádios são usados, em sua maioria, para concertos e jogos exibição de futebol.

O investimento em infraestrutura de transporte foi considerável, bem como a recuperação de bairros carentes como Soweto, que se transformou em atração turística da cidade de Johannesburgo, com tours para a casa nata de Nelson Mandela e outros espaços públicos. No entanto, os bairros contíguos ao estádio não receberam nenhum projeto. Criaram-se imensas áreas vazias, usadas durante a Copa para estacionamentos e instalações temporárias que permaneceram, mesmo depois do megaevento, ao lado de grandes passivos de áreas de mineração em meio urbano.

O rio Klipspruité um elemento da paisagem de grande potencial e se os projetos planejados pelo Governo se concretizarem, pode-se transformar em um eixo de desenvolvimento para toda a região e parte do legado da Copa do Mundo na cidade (figuras 72 e 73).

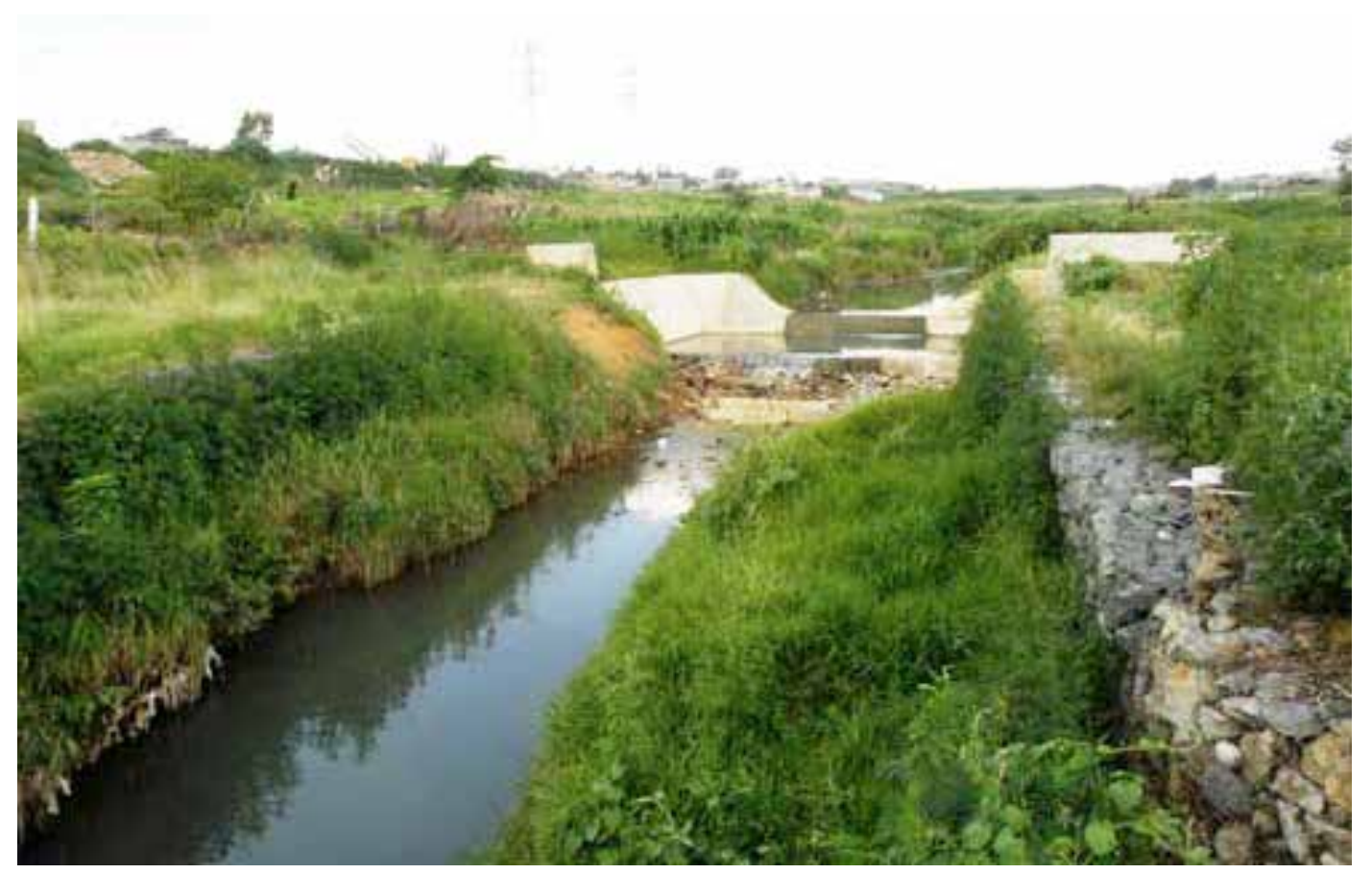




\section{ARENA SOCCER CITY - JOHANNESBURG, AFRICA DO SUL}

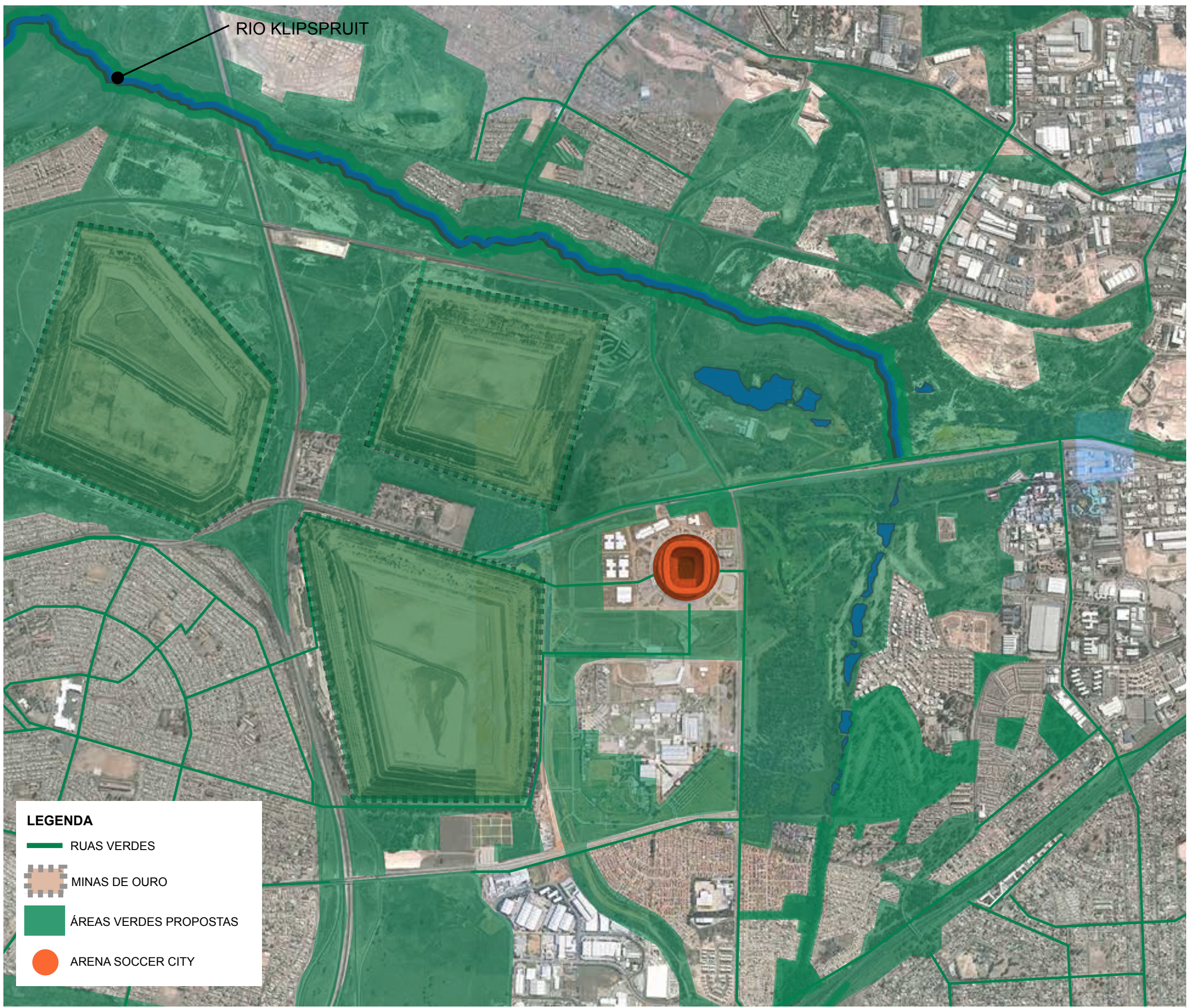

ESCALA 1:2500

Figura 73: Potencialidade para a configuração de uma infraestrutura verde para o entorno do Soccer City ao longo do Rio Klipspruit. Mapeamento: Patrícia Akinaga. Base: Google Earth, 2010. 


\section{CAPÍTULO 8 \\ O CASO DA ARENA CORINTHIANS EM ITAQUERA, SÃO PAULO}

8.1 UMA NOVA ARENA EM ITAQUERA

8.2 ARENA COMO UM ÍCONE E ELEMENTO DE IDENTIDADE

8.3 A EXPANSÃO DA ZONA LESTE DE SÃO PAULO

8.4 O BAIRRO DE ITAQUERA, REFERÊNCIAS HISTÓRICAS

8.50 ENTORNO DA ARENA CORINTHIANS, UM CENÁRIO PARA O URBANISMO ECOLÓGICO EM ITAQUERA 


\subsection{UMA NOVA ARENA EM ITAQUERA}

O Brasil foi escolhido como país sede da Copa do Mundo de Futebol de 2014 pela entidade internacional FIFA. Doze cidades sediarão os jogos: Belo Horizonte, Brasília, Cuiabá, Curitiba, Fortaleza, Manaus, Natal, Porto Alegre, Recife, Rio de Janeiro, Salvador e São Paulo.

Em São Paulo, optou-se pela construção de um novo estádio denominado Arena Corinthians, no bairro de Itaquera, na Zona Leste de São Paulo. O estádio faz parte do polo institucional, junto à estação de Metrô Corinthians-Itaquera, projetado pela Secretaria Municipal de Desenvolvimento Urbano da Prefeitura de São Paulo, SMDU.

A Arena Corinthians tem como responsável por sua construção a empreiteira Odebrecht Infraestrutura. O estádio terá capacidade para 48 mil lugares permanentes, sendo que durante o evento da Copa este número será acrescido de 20 mil assentos removíveis. A Odebrecht e o clube de futebol Corinthians iniciaram as negociações em 2004 para a construção da nova arena. Em 2010, como parte das comemorações do centenário corintiano, foi firmado o acordo entre as duas partes. A obra foi orçada em R\$ 820 milhões e o empreendimento foi iniciado em 30 de maio de 2011. O projeto arquitetônico da Arena Corinthians é de autoria do escritório carioca Coutinho, Diegues, Cordeiro Arquitetos. (Disponível em: <http://www.portal2014.org. br>. Acesso em: 4 de Março de 2012 e 20 de Agosto de 2013).

O programa do novo estádio, segundo publicado no site da Odebrecht, possui na área de terreno de 198 mil metros quadrados, 189 mil metros quadrados de área construída com: 3.520 estacas que compõem a fundação, 900 pilares pré-moldados, 2.500 vigas pré-moldadas, 9.700 lajes pré-moldadas, 4.000 degraus pré-moldados, 1.943 vagas de estacionamento descoberto, 990 vagas de estacionamento coberto, 89 camarotes, 48.000 assentos, 502 sanitários, 59 lojas, 15 elevadores, 10 escadas rolantes, auditório, 4 restaurantes, cozinha industrial, 8.900 metros quadrados de fachada em vidro (prédio oeste), ar condicionado (prédios leste e oeste) e 31.500 metros quadrados de cobertura metálica.

A área escolhida para a implantação da arena e do polo era originalmente ocupada pelo leito ferroviário da Estrada de Ferro Central do Brasil em 1970 ao norte, por uma pedreira ao sul, tendo a parte central totalmente desocupada e banhada por córregos, entre eles o Rio Verde. 
Nos anos de 1980, a área recebeu a construção da estação de Metrô/CPTM Corinthians-Itaquera e as obras do pátio de manobras do Metrô. Em 2003, consolida-se na área o Poupatempo Itaquera, a implantação de glebas públicas da Prefeitura Municipal de São Paulo da COHAB, uma gleba da Prefeitura então cedida para a construção da nova arena e a destinação da área para empreendimento privado, originalmente ocupada pela pedreira já desativada. Em 2007, a área recebe a implantação do Shopping Itaquera e verifica-se o parcelamento executado pelo empreendimento privado na porção sul (figura 74). (Secretaria Municipal de Desenvolvimento Urbano (SMDU), 2012)

O Rio Verde (figura 75) que corta a área, próximo à favela da Paz e do pátio do Metrô, receberá o Parque Linear Rio Verde, atualmente em projeto. A Prefeitura projetou um novo sistema viário de acesso ao shopping e transposição em desnível da via férrea, conectada à principal via expressa da região, a Radial Leste. As demais ruas são estreitas e congestionadas, pois o dimensionamento é adequado apenas para o tráfego local. Com a implantação do polo e da arena, já nota-se a alteração da dinâmica do entorno, que pode se tornar uma oportunidade de transformação da paisagem de toda a região com o incremento de recursos. É importante salientar que em cidades como Los Angeles e São Francisco, ambas no Estado da Califórnia, nos Estados Unidos, a construção das arenas foi indutora de desenvolvimento econômico e ambiental de suas vizinhanças como já apresentado no capítulo 6 desta tese. Itaquera terá a mesma oportunidade?

Em 2007, a área do polo institucional possuía 647.617 metros quadrados de glebas vazias, sendo 198.501 metros quadrados cedidos pela Prefeitura para construção da arena. Foram projetadas pela Secretaria Municipal de Desenvolvimento Urbano, SMDU, equipamentos públicos e áreas verdes nas áreas pertencentes à Prefeitura como um Fórum, uma Rodoviária, uma FATEC/ETEC, um Centro de Capacitação e Formação Profissional do SENAI, uma Incubadora e Laboratórios para o Parque Tecnológico da Zona Leste, um Centro de Convenções e Eventos, um Batalhão da Polícia Militar, uma obra social/assistencial e o Parque Linear Rio Verde. 
Figura 74

Arena Corinthians e polo

institucional.

Fonte: SMDU
Figura 75

Córrego Rio Verde no entorno da

Arena Corinthians.

Foto: Patrícia Akinaga,

23 outubro de 2013
Polo Institucional Itaquera - Plano Geral (proposta)

G. PREFEITURA DE SÁO PAULO

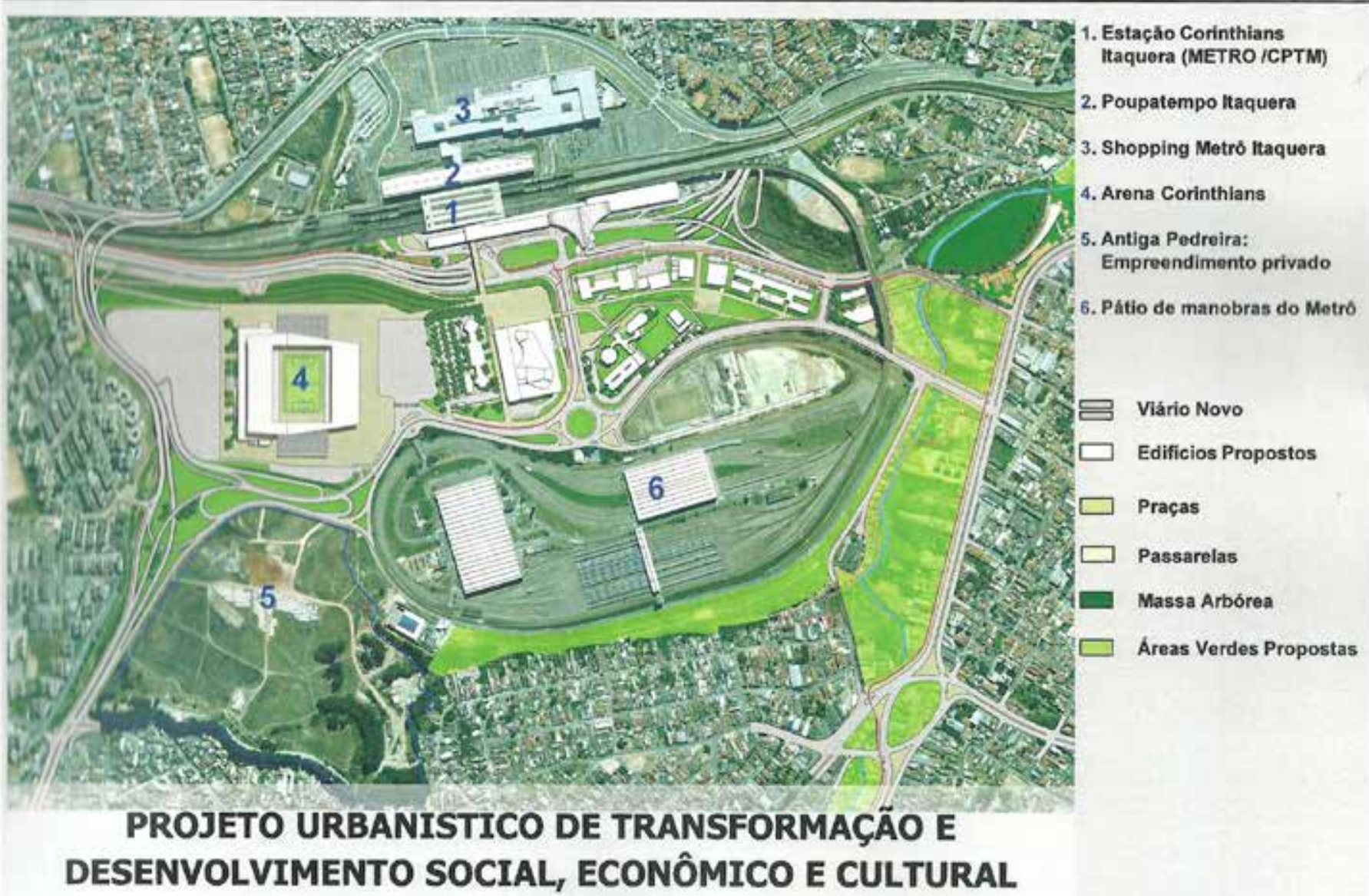

DESENVOLVIMENTO SOCIAL, ECONÔMICO E CULTURAL

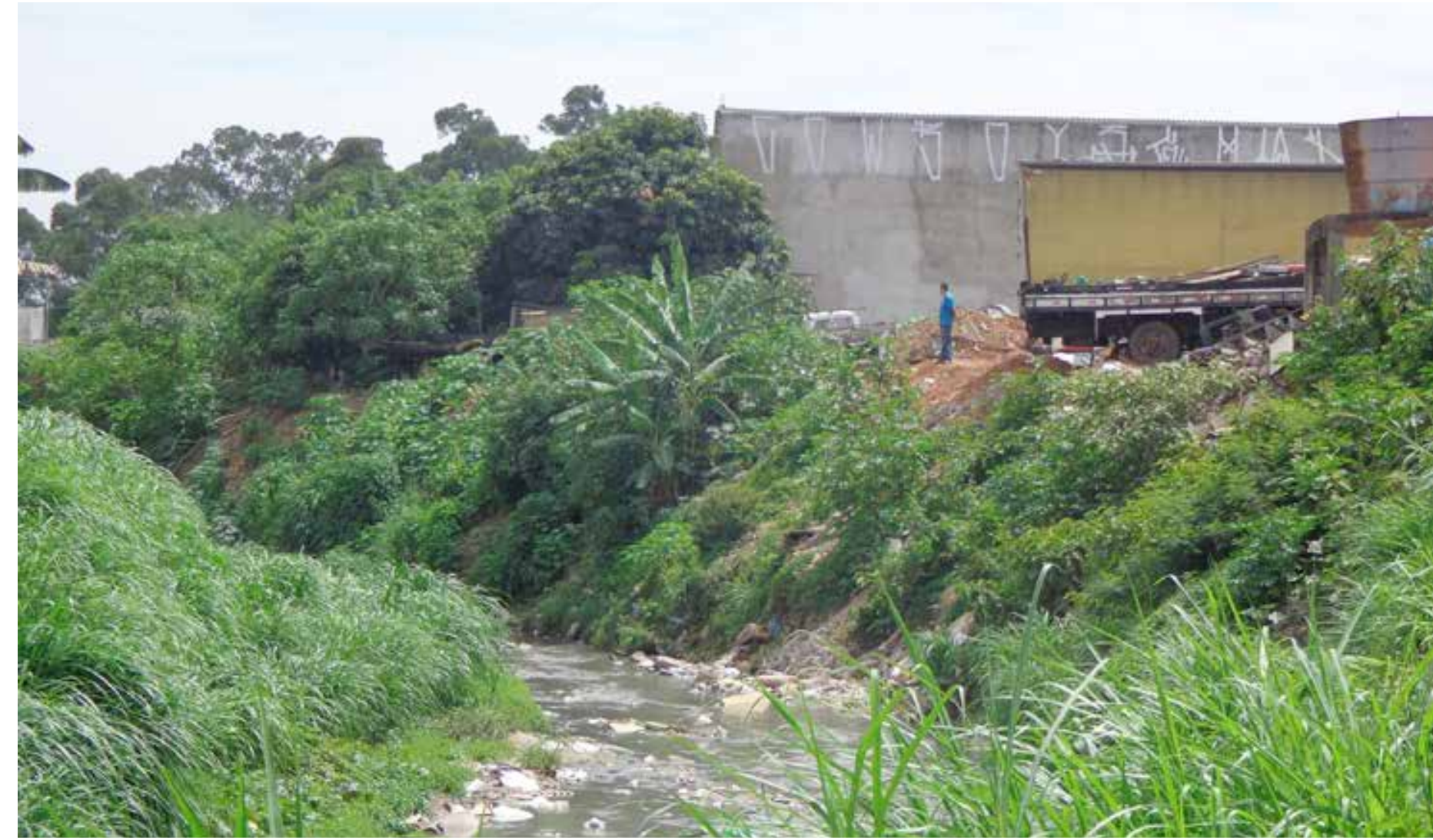




\subsection{ARENA COMO UM ÍCONE E ELEMENTO DE IDENTIDADE}

A Arena Corinthians poderá se tornar um ícone e fortalecer a identidade de Itaquera, bairro afastado do centro, caracterizado pela ocupação densa de suas várzeas, terras antes ocupadas por chácaras destinadas à agricultura organizada pela colônia japonesa. Nomes de vias importantes como a Avenida Jacu-Pêssego carregam a memória da importância das águas e das plantações no início do povoamento e posterior consolidação do bairro de Itaquera.

“Novos ícones podem ajudar a cidade a sobreviver - possivelmente através da criação de uma nova identidade urbana", segundo o autor Albert Speer, em A Manifesto for Sustainable Cities, "um ícone não precisa ser resultado do desperdício de recursos financeiros. Infelizmente, alguns arquitetos, vereadores e empreendedores evidentemente confundem ícone com glamour ou despesa e projetam o edifício de acordo com esta ideia. Ao invés disso, um ícone poderia ser modesto e ainda assim preencher a função de identidade, oferecer aos cidadãos um ponto de identificação com a sua cidade ou com a sua futura casa" (GAINES; JÄGER, 2009).

O impacto causado por ícones é reconhecido, se a cidade puder investir na transformação urbana, o ícone poderá se transformar em um bom investimento e que servirá de marco para a criação de uma nova identidade. Um estádio, segundo Albert Speer, é um ícone clássico urbano, ele cita a identificação de Roma com o Coliseu e de Londres com Wembley. Segundo Paul Henry, arquiteto do escritório HOK Sports, equipamentos esportivos refletem emoções de glórias do presente e do passado, e compara o efeito da arquitetura contemporânea dos estádios ao papel da arquitetura das catedrais na Idade Média.

A Arena Corinthians (figura 76) destaca-se na paisagem de Itaquera por sua arquitetura contemporânea, mas, sobretudo, pela sua escala e posição geográfica. Mesmo antes de sua abertura, tornou-se um ícone do bairro e parte de uma nova identidade desejada, o bairro de Itaquera como futuro polo de desenvolvimento para a Zona Leste da cidade de São Paulo. 

Foto: Patrícia Akinaga, 23 outubro de 2013.

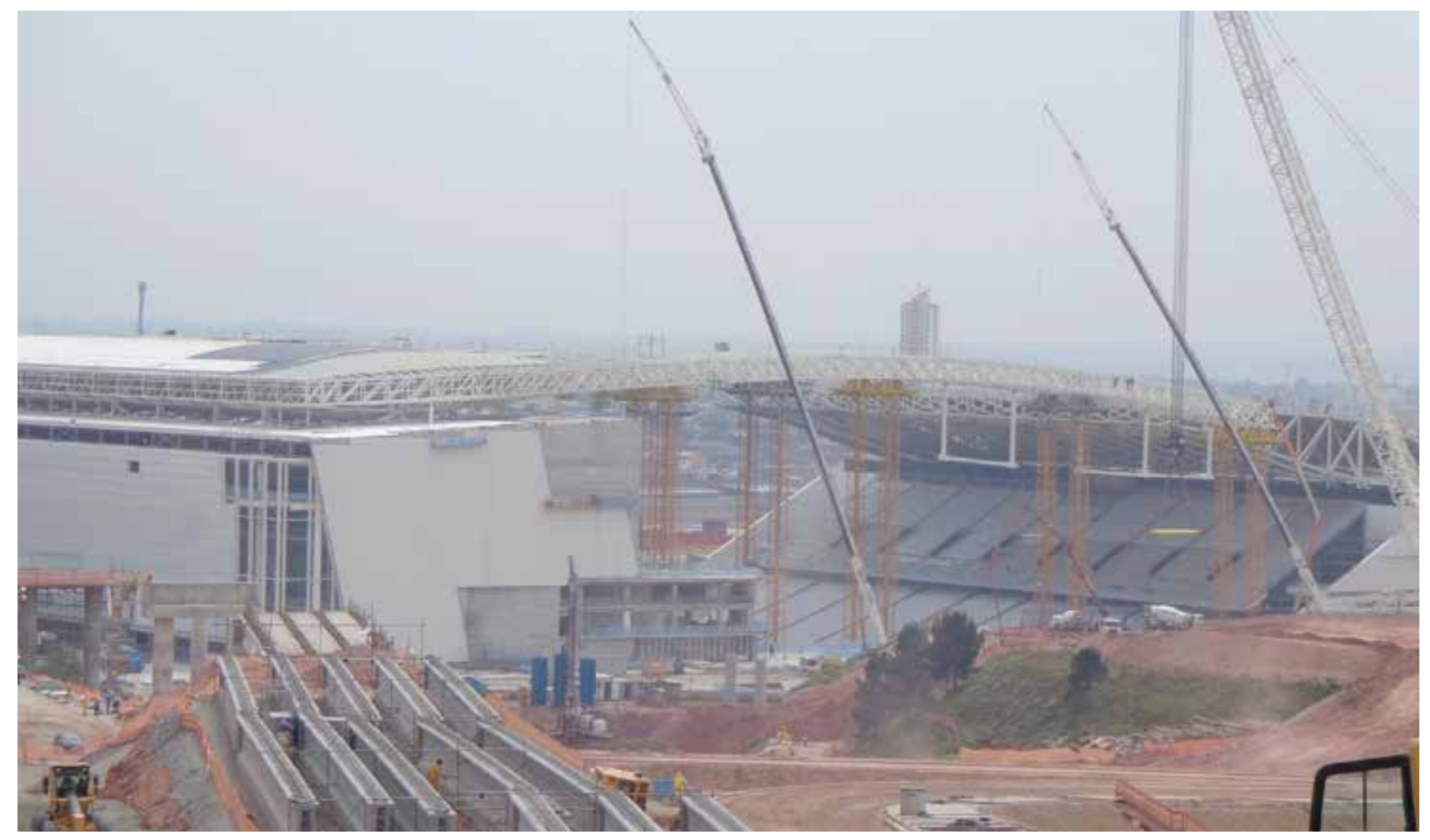

\subsection{A EXPANSÃO DA ZONA LESTE DE SÃO PAULO}

Em seu livro "A Leste do Centro", Meyer e Grostein (2010) identificam três fatores associados à expansão a leste do Município de São Paulo. O primeiro refere-se à implantação da ferrovia e suas estações nas várzeas e baixos terraços fluviais no final do século XIX e nas duas primeiras décadas do século $X X$, o que propiciou nos terrenos planos e baratos a instalação de indústrias e bairros operários como Brás, Belém, Mooca e Ipiranga. A ferrovia também proporcionou a formação de subúrbios residenciais cruzados pelos trilhos e polarizados por suas estações como foi o caso de Itaquera, Poá, Guaianases e São Miguel Paulista, resultando, segundo as autoras, em dois padrões distintos de ocupação urbana.

O segundo fator responsável pela expansão leste de São Paulo apontado pelas autoras foi a introdução do ônibus como modo de transporte público, que sob pneus, deu liberdade para o desenvolvimento em qualquer direção do território. Como consequência, estavam dadas, a partir dos anos 1940 e 1950, as condições suficientes para a instalação do padrão de urbanização precária da periferia, da qual faz parte o bairro de Itaquera (figuras 77 e 78) (MEYER; GROSTEIN, 2010). 
Figura 77:

Conjuntos habitacionais no entorno da Arena Corinthians.

Foto: Patrícia Akinaga, 23 outubro de 2013.

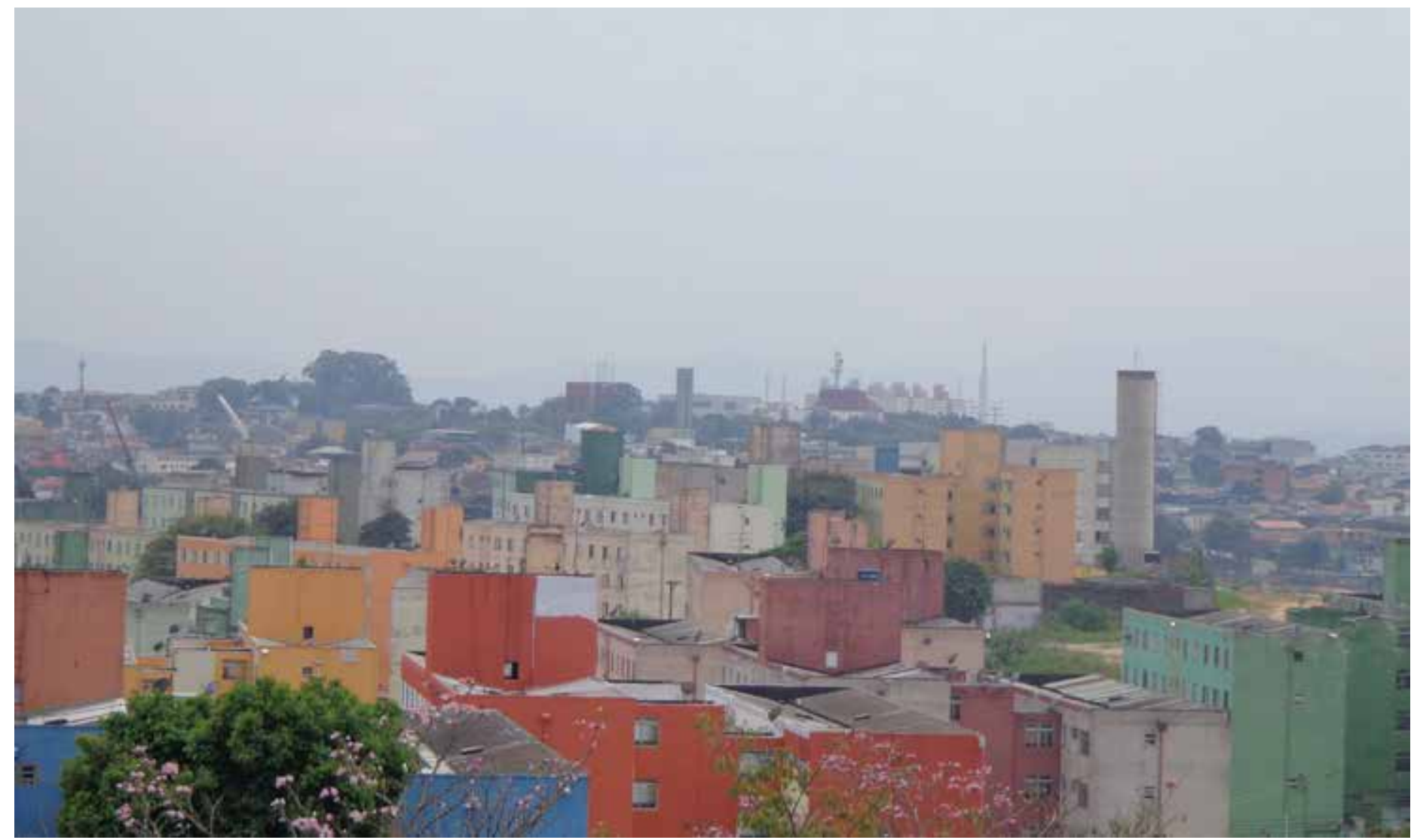

Figura 78:

Tipologia representativa das ruas do entorno da Arena Corinthians em Itaquera. Foto: Patrícia Akinaga, 23 de outubro de 2013.

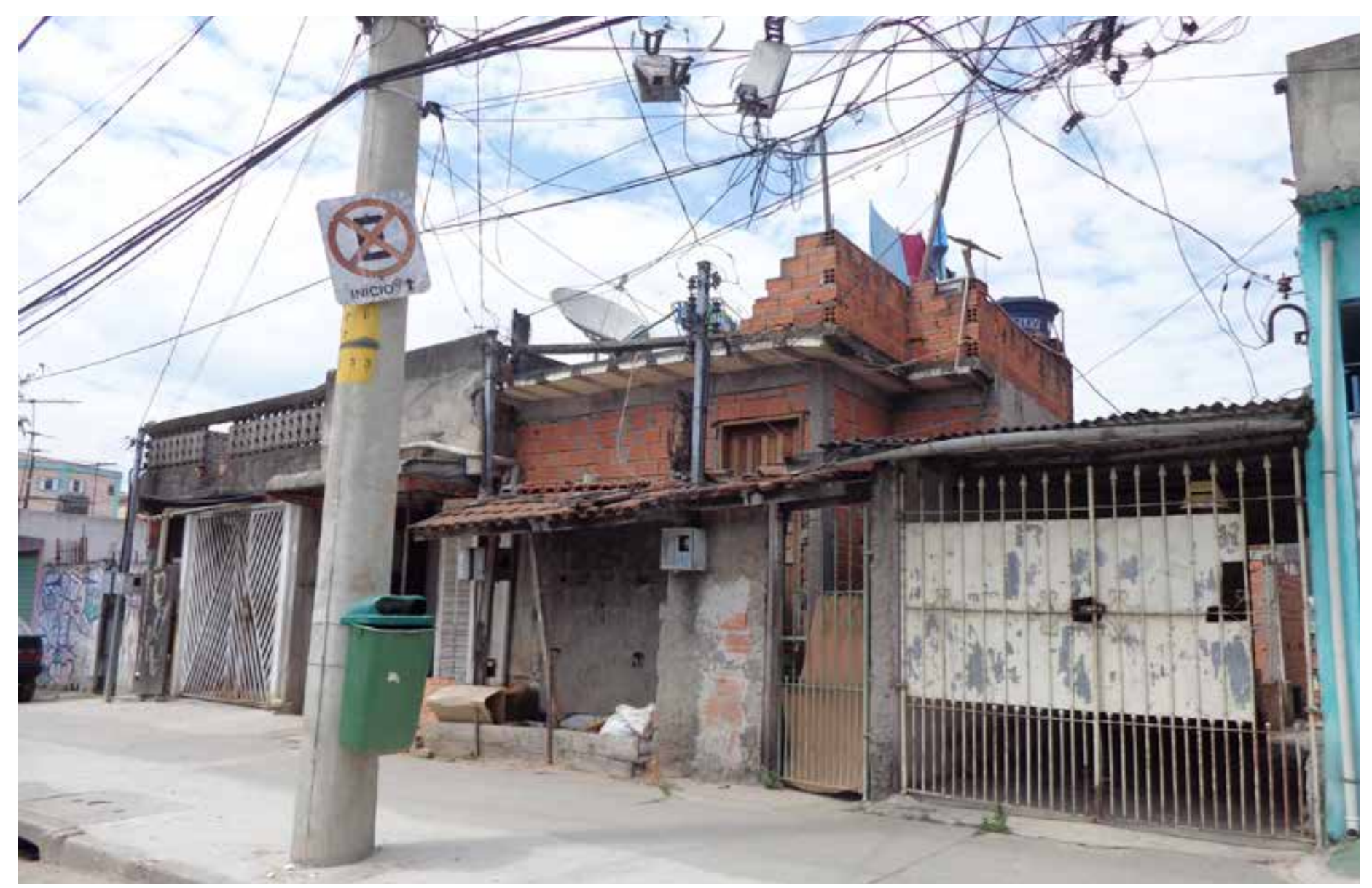


${ }^{1}$ Evento esportivo mundial de futebol organizado pela FIFA, entidade que estabelece padrões para as cidades sede quanto à infraestrutura e para a construção das arenas.

Figura 79: Imagem extraída do livro "A Leste do Centro" que ilustra o perímetro do Vetor Leste do Centro. Itaquera se desenvolve ao longo da Linha 3.
Segundo Meyer e Grostein (2010), o terceiro fator que contribuiu para a expansão da Zona Leste foi a aquisição por parte do poder público do estoque de propriedades rurais para a construção de conjuntos habitacionais de interesse social em meados da década de 1970, fato que colaborou para o crescimento populacional, além de replicar o padrão de urbanização que se tornou parte integrante da paisagem urbana de Itaquera e de toda a Região Leste.

A consequência imediata da reprodução dos conjuntos habitacionais na periferia é o problema de acessibilidade e mobilidade agravado pelo fato de estes bairros servirem somente como bairros dormitórios quando, devido à demanda populacional, juntamente com o investimento em infraestrutura, poderiam se transformar em polos de desenvolvimento da metrópole. Itaquera apresenta grande potencial de transformação a partir da construção da nova Arena Corinthians, uma das sedes da Copa do Mundo ${ }^{1}$ de 2014 e do polo institucional adjacente, planejado pela Secretaria Municipal de Desenvolvimento Urbano da Prefeitura de São Paulo.

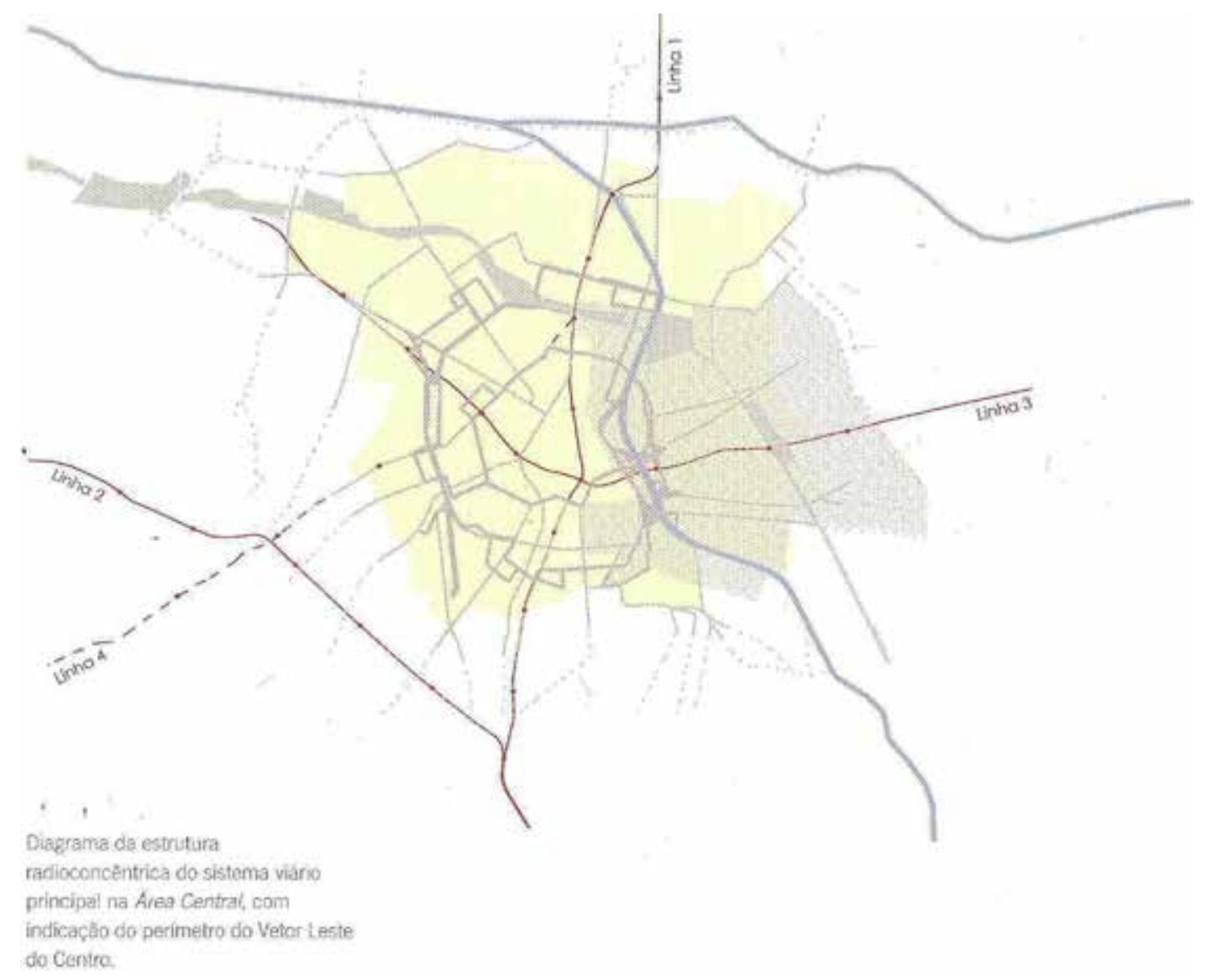


2 Companhia de Desenvolvimento Habitacional e Urbano, empresa do Governo Estadual vinculada à Secretaria de Habitação do Estado de São Paulo. Executa programas habitacionais em todo o Estado e atende a população de baixa renda de 01 a 10 salários mínimos.

3 Leste 1 compreende os distritos de Água Rasa, Aricanduva, Artur Alvim, Belém, Cangaíba, Carrão, Mooca, Penha, Ponte Rasa, São Lucas, Sapopemba, Tatuapé, Vila Formosa Vila Matilde e Vila Prudente. $O$ Leste 2 engloba CidadeTiradentes, Cidade Líder, Ermelino Matarazzo, Guaianases, Iguatemi, Itaim Paulista, Itaquera, Jardim Helena, José Bonifácio, Lajeado, Parque do Carmo, São Mateus, São Miguel, São Rafael, Vila Curuçá e Vila Jacuí (MEYER;GROSTEIN, 2010, p. 52).

Evolução populacional dos distritos da subprefeitura de Itaquera. Disponível em: <http:// www.prefeitura.sp.gov.br/cidade/ secretarias/subprefeituras/subprefeituras/dados_demograficos/ index.php? $p=12758>$ Acesso em: 28 out. 2013.
Dentre os argumentos mais frequentes usados pelo poder público para justificar a construção dos conjuntos habitacionais na Zona Leste e não nas áreas centrais, já dotadas de infraestrutura, estão a falta de recursos, a escassez e o valor elevado da propriedade. Verifica-se desde 2008 uma mudança nesta política com a construção de edifícios destinados à habitação popular, tendo a $\mathrm{CDHU}^{2}$ como responsável nas áreas centrais de Santa Cecília e Bela Vista, em substituição aos cortiços, o que não reduz, devido à alta demanda, a construção de conjuntos habitacionais em áreas periféricas.

O Plano Diretor Estratégico de São Paulo de 2002, Lei Municipal número 13.430, estabeleceu e mapeou as Zonas Especiais de Interesse Social (ZEIS 3), com o objetivo principal de reservar áreas centrais para produção de habitação. Tanto a Zona Leste 1 como a Leste $2^{3}$, conforme a Zona Leste é subdividida pela administração pública, foram beneficiadas; na primeira, a experiência de construção é mais recente.

O poder público promoveu cerca de 21 quilômetros quadrados de urbanização na Zona Leste, sem um plano de expansão urbana, com grande concentração de conjuntos que abrigam, aproximadamente 600 mil habitantes (MEYER; GROSTEIN, 2010).

Apesar da diminuição da taxa de crescimento, a tendência é o aumento do número absoluto de residentes nos distritos localizados na Região Leste 2, devido aos fatos expostos e à presença de áreas disponíveis para construção de novos empreendimentos. Como consequência, temos uma demanda crescente pelo investimento em transporte público.

A tabela abaixo foi extraída do site da Subprefeitura de Itaquera e mostra a evolução populacional de seus distritos:

\begin{tabular}{|llccccc|}
\hline Subprefeitura & Distritos & Área $\left(\mathbf{k m}^{2}\right)$ & $\begin{array}{c}\text { População } \\
(\mathbf{1 9 9 6 )}\end{array}$ & $\begin{array}{c}\text { População } \\
(\mathbf{2 0 0 0 )}\end{array}$ & $\begin{array}{c}\text { População } \\
(\mathbf{2 0 1 0 )}\end{array}$ & $\begin{array}{c}\text { Densidade } \\
\text { Demográfica } \\
\left(\mathbf{H a b} / \mathbf{k m}^{2}\right)\end{array}$ \\
\hline Itaquera & Cidade Líder & 10,2 & 107.913 & 116.666 & 126.597 & 12.411 \\
& Itaquera & 14,6 & 189.775 & 201.291 & 204.871 & 14.032 \\
& José Bonifácio & 14,1 & 105.808 & 107.069 & 124.122 & 8.803 \\
& Parque do Carmo & 15,40 & 59.838 & 63.985 & 68.258 & 4.432 \\
& TOTAL & 54,30 & 463.334 & 489.011 & 523.848 & 9.647 \\
\hline
\end{tabular}


4 Disponível em: <http://www. ambiente.sp.gov.br/apa-parque-efazenda-do-carmo $>$. Acesso em: 30 out. 2013.
Apesar do investimento do poder público em serviços como abastecimento de água e de saneamento nos anos de 1980 e das melhorias na acessibilidade e no transporte público da década de 1990, a precariedade da urbanização do trecho Leste 2, que engloba Itaquera, ainda persiste. O sistema de transporte urbano sobre trilhos sofreu investimentos como as obras de prolongamento da linha 3 (Vermelha) do Metrô até Guaianases, melhorias no sistema de trens metropolitanos (leste-oeste), construção de corredores metropolitanos de ônibus e de avenidas perimetrais de alcance regional, como a Jacu-Pêssego (MEYER; GROSTEIN, 2010).

Além das vias expressas, dos trilhos e dos conjuntos habitacionais, o bairro de Itaquera possui atributos naturais importantes por estar localizado entre o Parque Ecológico doTietê e a Área de Proteção Ambiental (APA) do Carmo, importante reserva verde com 867,60 hectares de Mata Atlântica. A APA, Parque e Fazenda do Carmo foram criados pela Lei Estadual $n^{\circ} 6409$, de 5 de abril de 1989 e regulamentados pelo Decreto Estadual n³7678, de 20 de outubro de 1993, que estabeleceu o seu zoneamento e o seu Conselho Gestor que tem como tarefa principal mobilizar a comunidade da região para recuperação das áreas degradadas e urbanização das glebas ocupadas, além de manifestar-se sobre os projetos que interferem na APA.

Esta APA tem como objetivo proteger a extensa área coberta com remanescentes da Mata Atlântica, que abriga espécies da flora como o jequitibá, pau d'álho, canela, bromélias e de fauna como inhambu, pitiguari, jacu, gambá, tatu-galinha, morcegos e serpentes. ${ }^{4}$

A área ocupada pelo Parque do Carmo, com mais de 1,5 milhão de metros quadrados, integrava originalmente a Fazenda Caguassu, cuja área total ultrapassava os sete milhões de metros quadrados (figura 80).

Os carmelitas dividiram a fazenda em várias glebas no começo do século XX. Uma delas foi adquirida em 1919 pelo Coronel Bento Pires de Campos, que ali instalou a Companhia Comercial Pastoril e Agrícola e abriu um loteamento. Uma imagem de Nossa Senhora do Carmo encontrada na capela da casa sede inspirou o nome do lugar: Fazenda Nossa Senhora do Carmo ou, simplesmente, Fazenda do Carmo. 
Figura 80: Parque do Carmo. Foto: Patrícia Akinaga, 23 de outubro de 2013.

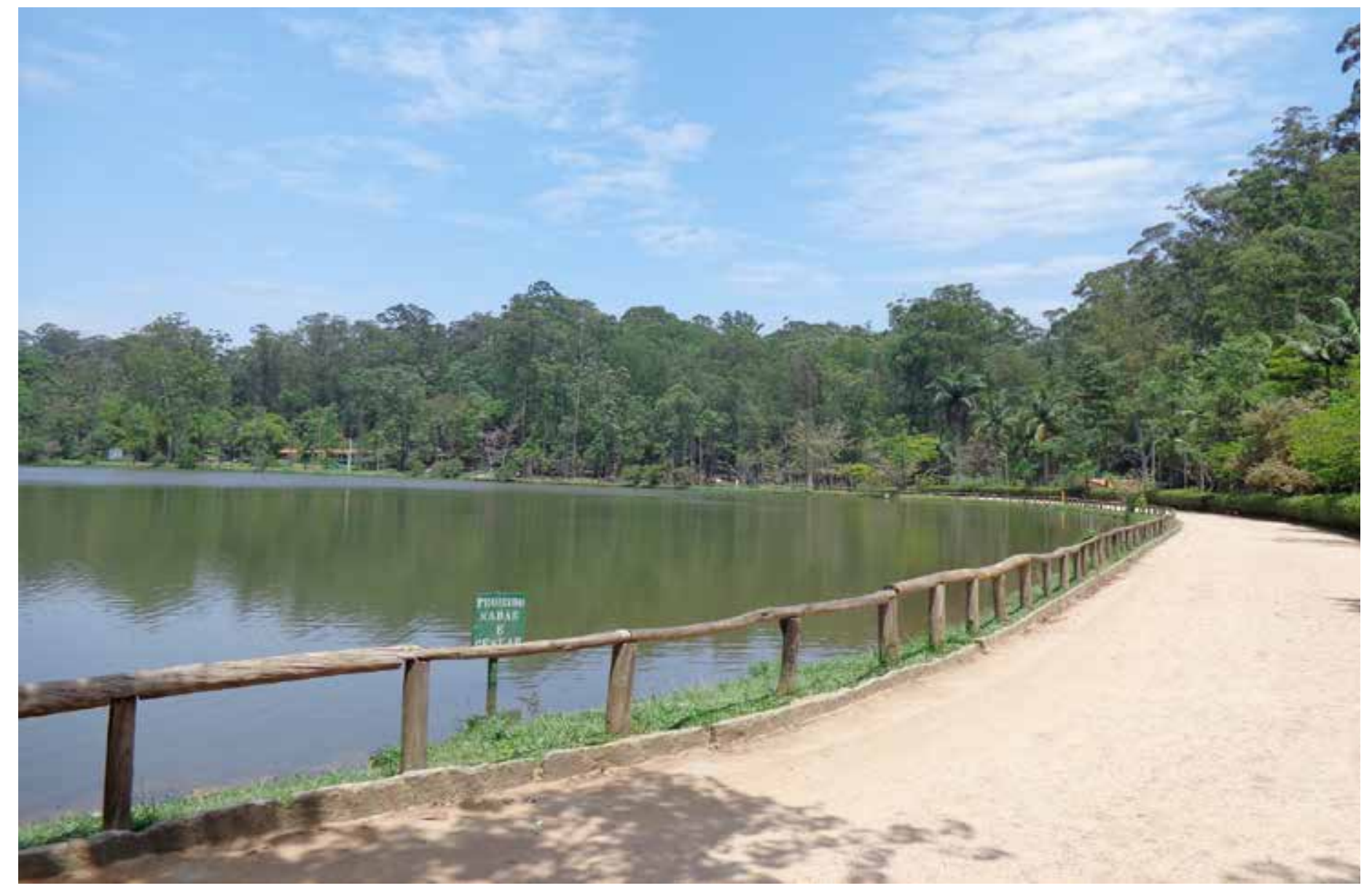

O que restou da antiga fazenda foi vendido para o empresário paulista Oscar Americano, em 1951. Finalmente, em 1976, a área foi desapropriada pela Prefeitura para ser transformada em parque público, oferecendo lazer aos moradores de Itaquera e da Zona Leste em geral.

Nos últimos 10 anos, o Parque do Carmo passou por reformas estruturais para proporcionar opções de lazer aos seus milhares de visitantes. Uma área de 6 milhões de metros quadrados reúne o Centro de Educação Ambiental, um museu, uma horta com espécies medicinais, uma biblioteca, churrasqueiras, aparelhos de ginástica, campo de futebol, ciclovia, anfiteatro, um planetário, construído com a parceria da iniciativa privada em 2004, e um parque infantil. Uma extensa área verde está preservada, com cafezais e cerejeiras japonesas, seis lagos com pequenas ilhas e fauna diversa. 
${ }^{5}$ Disponível em: <http://www. prefeitura.sp.gov.br/cidade/ secretarias/subprefeituras/itaquera/ historico/>. Acesso em: 28 out. 2013.

\subsection{O BAIRRO DE ITAQUERA, REFERÊNCIAS HISTÓRICAS}

Segundo dados da Subprefeitura de Itaquera, a primeira referência da povoação do bairro data de 1820, local onde existia um pequeno rancho conhecido como a "Casa Pintada", parada de abastecimento de provisões para os viajantes. O nome Itaquera é de origem tupi e quer dizer "pedra dura".

A data de aniversário escolhida pela comunidade é 6 de novembro de 1875, quando o bairro começa a se desenvolver a partir da inauguração da estação de trem local.

A Arena Corinthians localiza-se na Subprefeitura de Itaquera, na zona leste do município de São Paulo (figuras 81, 82 e 83). Segundo dados da Subprefeitura, a estrutura geológica da área é constituída de rochas antigas do tipo cristalino, como granitos da era arqueozóica, rochas metamórficas, gnáissicas que propiciam uma base sólida para ocupação urbana e micaxistos micáceos, áreas propensas a escorregamentos de terra (figura 84). A unidade estrutural é representada por um conjunto de superfícies elevadas cristalinas conformadas pela erosão que causou a redução de altitude entre 700 e 800 metros.

A topografia é caracterizada por morros cujas elevações mamelonares evidenciam o intenso trabalho erosivo das águas superficiais presentes na área. O principal rio que banha o bairro de Itaquera é o rio Jacu, e na área de implantação da futura arena Corinthians há uma série de córregos, característica da hidrografia da região, formada por uma rede rios afluentes e subafluentes do rioTietê que fazem parte da Bacia do AltoTietê. Além do rio Jacu destacamse os rios Itaquera, Aricanduva e Verde (ver figura 85).

No final do século XIX, chega ao bairro a primeira "Maria-Fumaça" pertencente à antiga Estrada de Ferro do Norte e os trilhos ferroviários passaram a se tornar evidentes elementos da paisagem local ao cortar planícies e montanhas.

A industrialização crescente de São Paulo e a ferrovia impulsionaram o crescimento populacional do bairro e sua urbanização ocupou as várzeas e morros, transformando o povoado de Caaguassu na Itaquera de hoje ${ }^{5}$. 


\section{CONTEXTO GERAL}

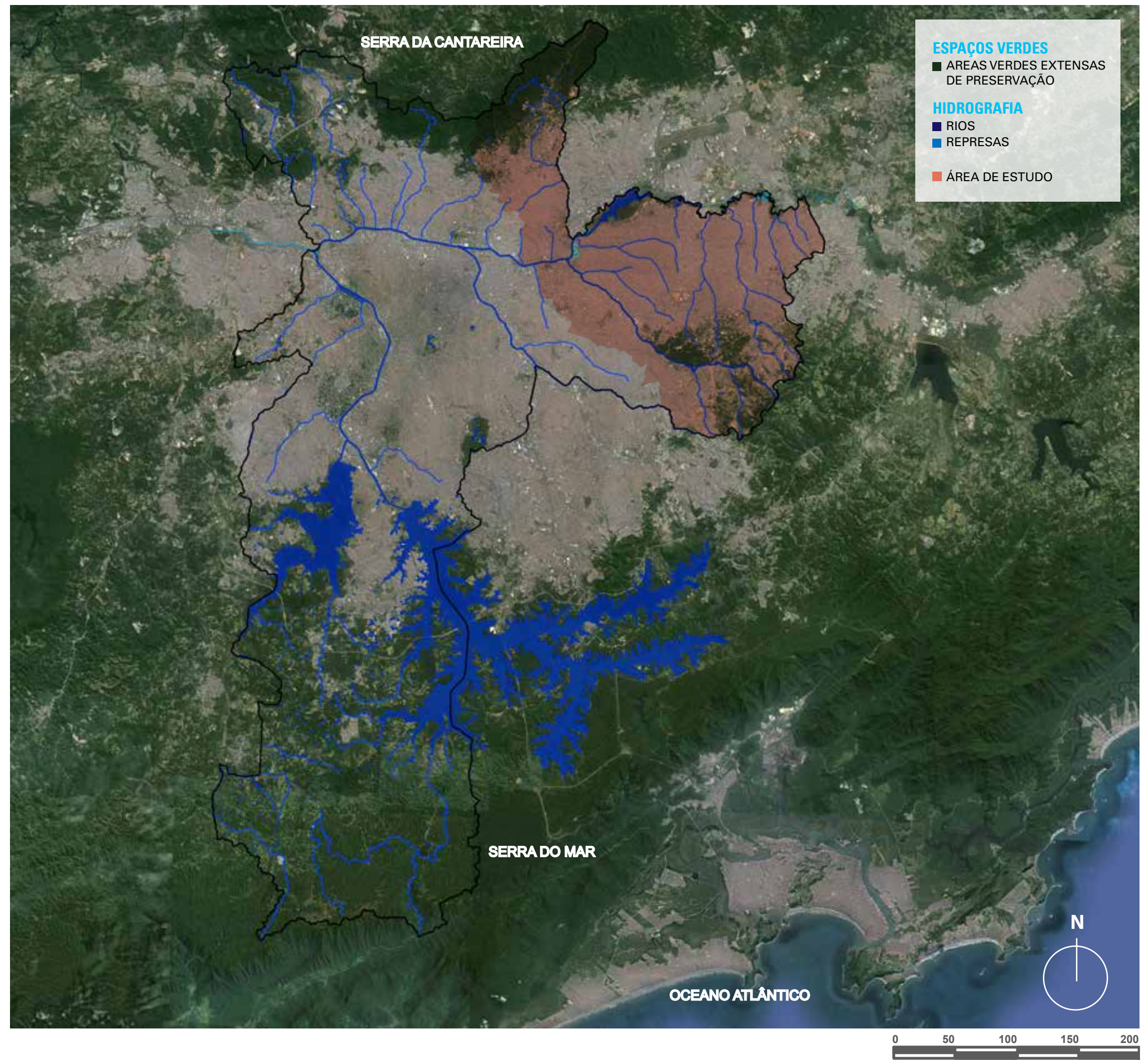

Figura 81: Contexto geográfico da área de estudo localizada entre a Serra da Cantareira e a Serra do Mar. Fonte: Prefeitura de São Paulo: http://infocidade.prefeitura.sp.gov.br/mapas/3_regioes_subprefeituras_e_distritos_2013_10338.pdf. Base: Mapa Digital da Cidade, SMDU, Prefeitura de São Paulo, 2004. Mapeamento: Patricia Akinaga. Imagem de satélite: Google Earth, 2011 
REGIÕES, DISTRITOS

E SUBPREFEITURAS DE SÃO PAULO

$\begin{array}{ll}01 & \text { PERUS } \\ 02 & \text { PIRITUBA }\end{array}$

03 FREGUESIA /BRASILÂNDIA

04 CASA VERDE/CACHOEIRINHA

5 SANTANA/TUCURUVI

JAÇANÃ/TREMEMBÉ

VILA MARIA/VILA GUILHERME

LAPA

SÉ

BUTANTÃ

VILA MARIANA

VILA MARIAN

SANTO AMARO

JABAQUARA

CIDADE ADEMAR

CAMPO LIMPO

M'BOI MIRIM

CAPELA DO SOCORRO

PARALHEIROS

PENHA

ERMELINO MATARAZZO

SÃO MIGUEL

ITAIM PAULISTA

MOOCA

ARICANDUVA/FORMOSA/CARRĀO

ITAQUERA

GUAIANAZES

VILA PRUDENTE

SÃO MATEUS

CIDADETIRADENTES

2 SAPOPEMBA

REGIÃO

DISTRITO

ÁREA DE ESTUDO

Figura 82:

Localização da abrangência da área de estudo na zona leste do município de São Paulo. Fonte: Prefeitura de São

Paulo: <http://infocidade. prefeitura.sp.gov.br/mapas/3_

regioes_subprefeituras_e

distritos_2013_10338.pdf> Base: Mapa Digital da Cidade, SMDU, Prefeitura de São Paulo, 2004

\section{GRANDE SÃO PAULO}

\section{(}

\{

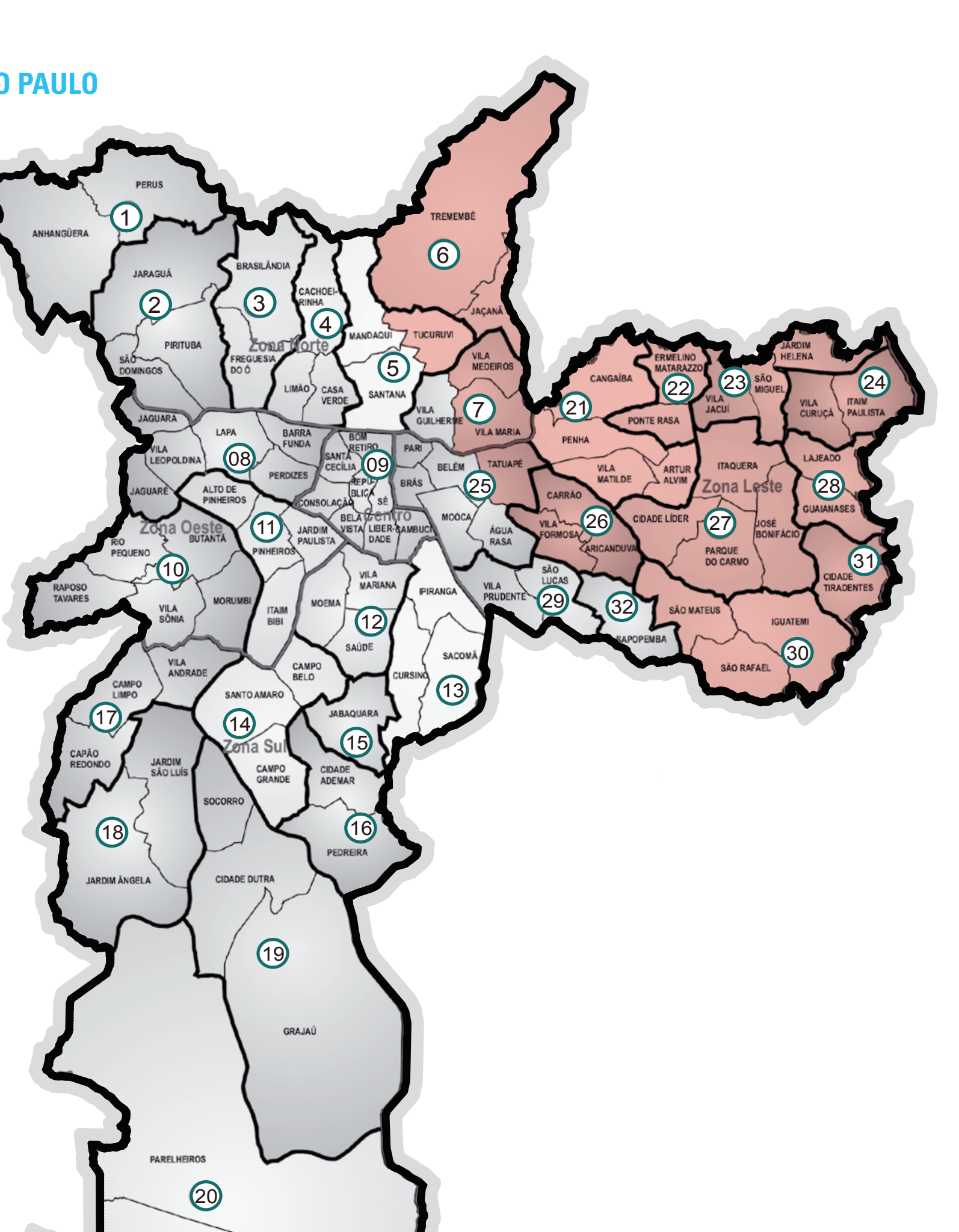

(6)

(6)

7

(2) (3)

5

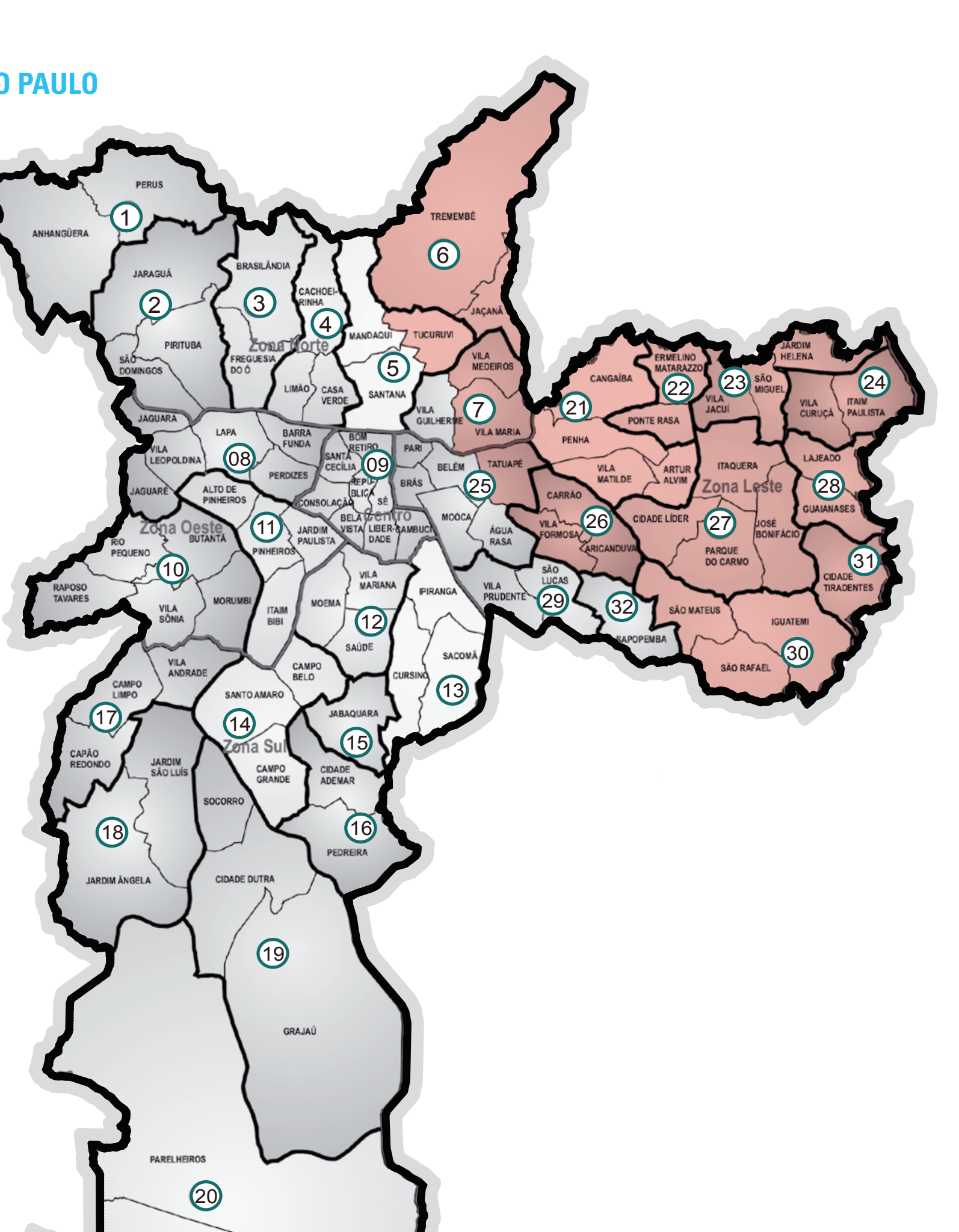

PIRTUBA

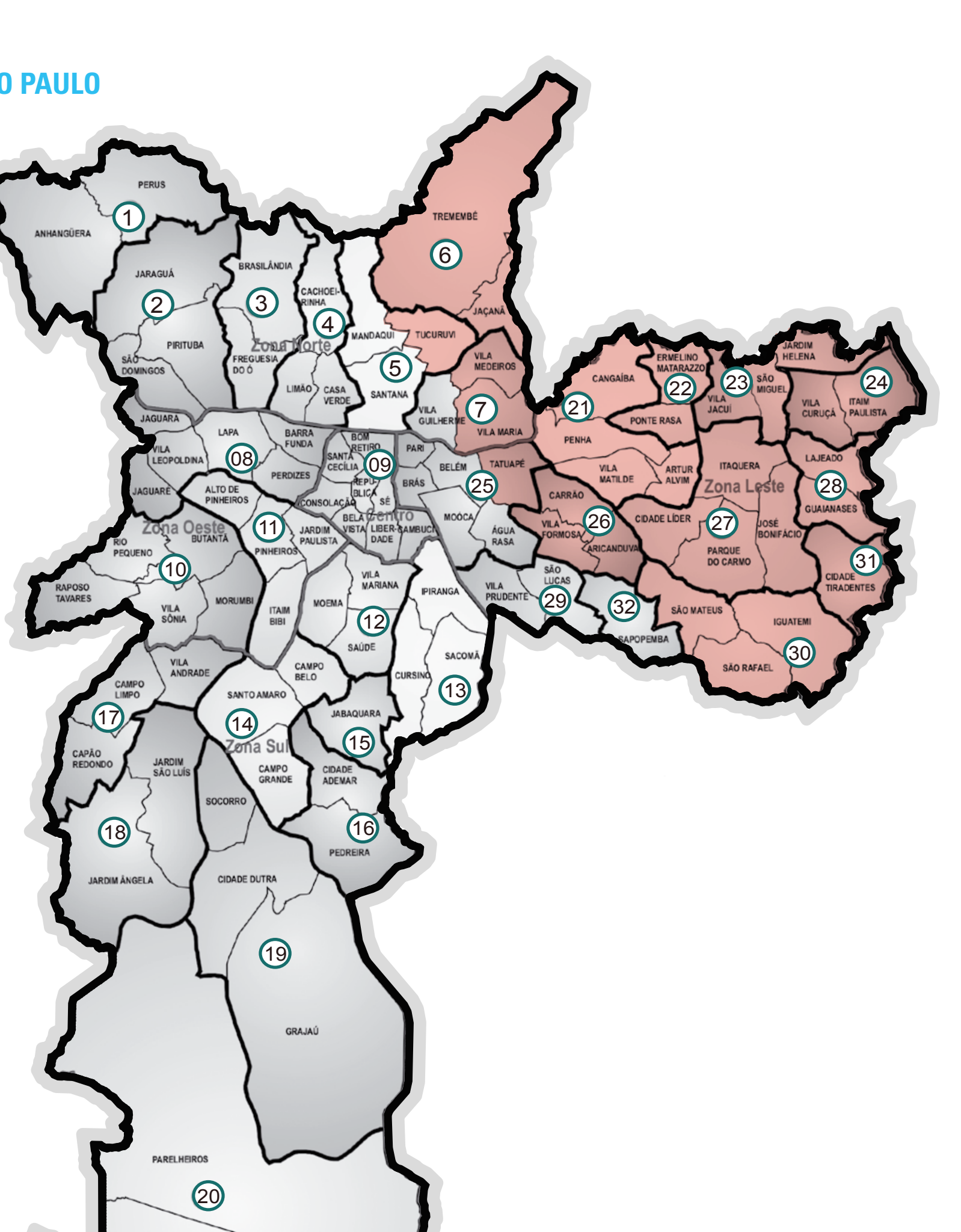

$\left\{\begin{array}{c}\text { EREGUESAM } \\ \text { Do }\end{array}\right.$

(n)
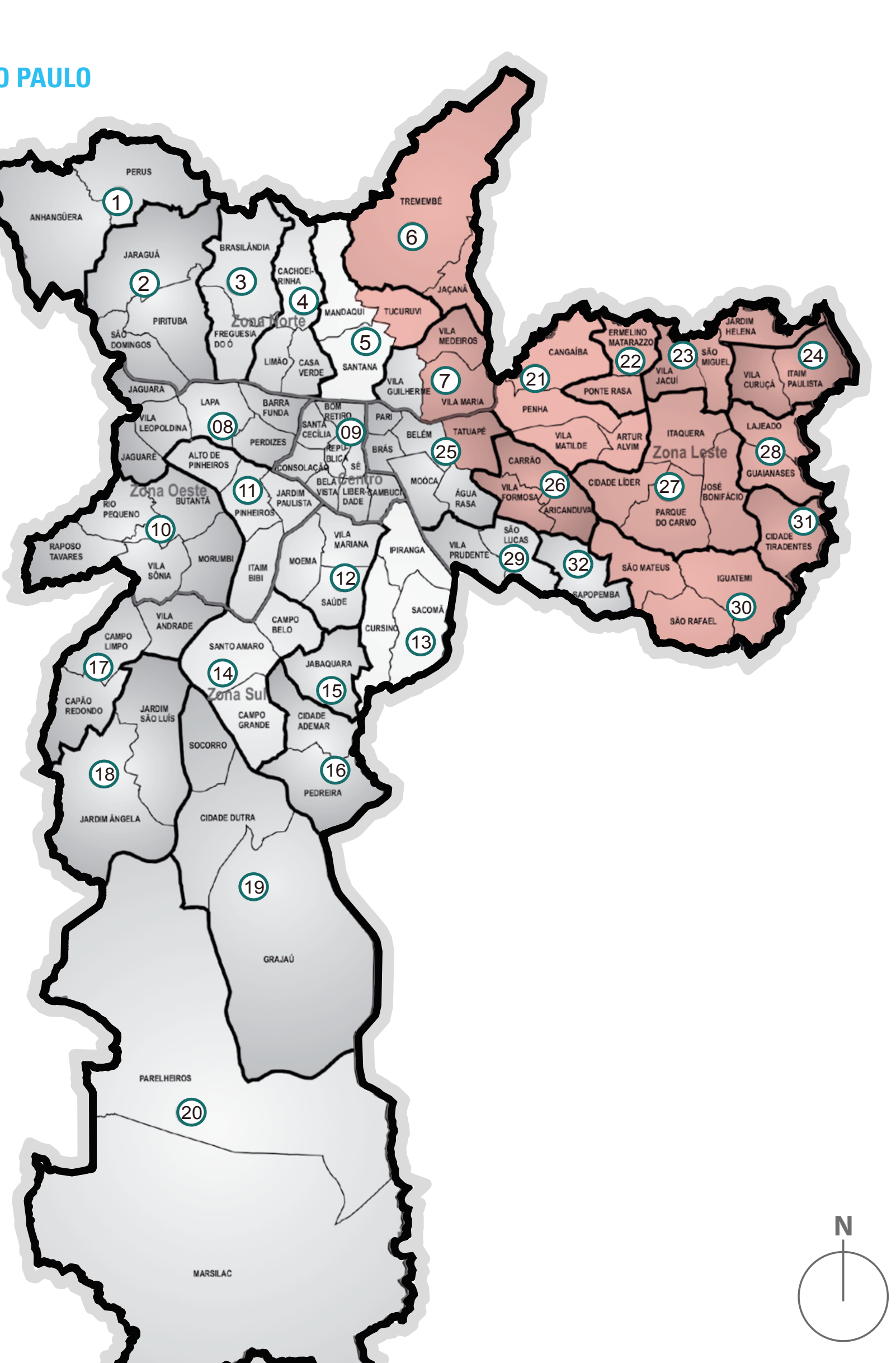
LEGENDA

SUBPREFEITURAS DE SÃO PAULO

01 - JAÇANÃ̃TREMEMBÊ

02 - SANTANA/TUCURUVI

03 - VILA MARIA

05 - ARICANDUVA/FORMOSA/CARRÃO

06 - PENHA

07 - ERMELINO MATARAZZO

08 - ITAQUERA

09 - SÃO MATEUS

10 - CIDADE TIRADENTES

11 - GUAIANAZES

12 - SAO MIGUEL

13 - ITAIM PAULISTA

MUNICÍPIOS

14 - GUARULHOS

15 - FERRAZ DE VASCONCELOS

ARENA CORINTHIANS

\section{LOCALIZAÇÃO}

1

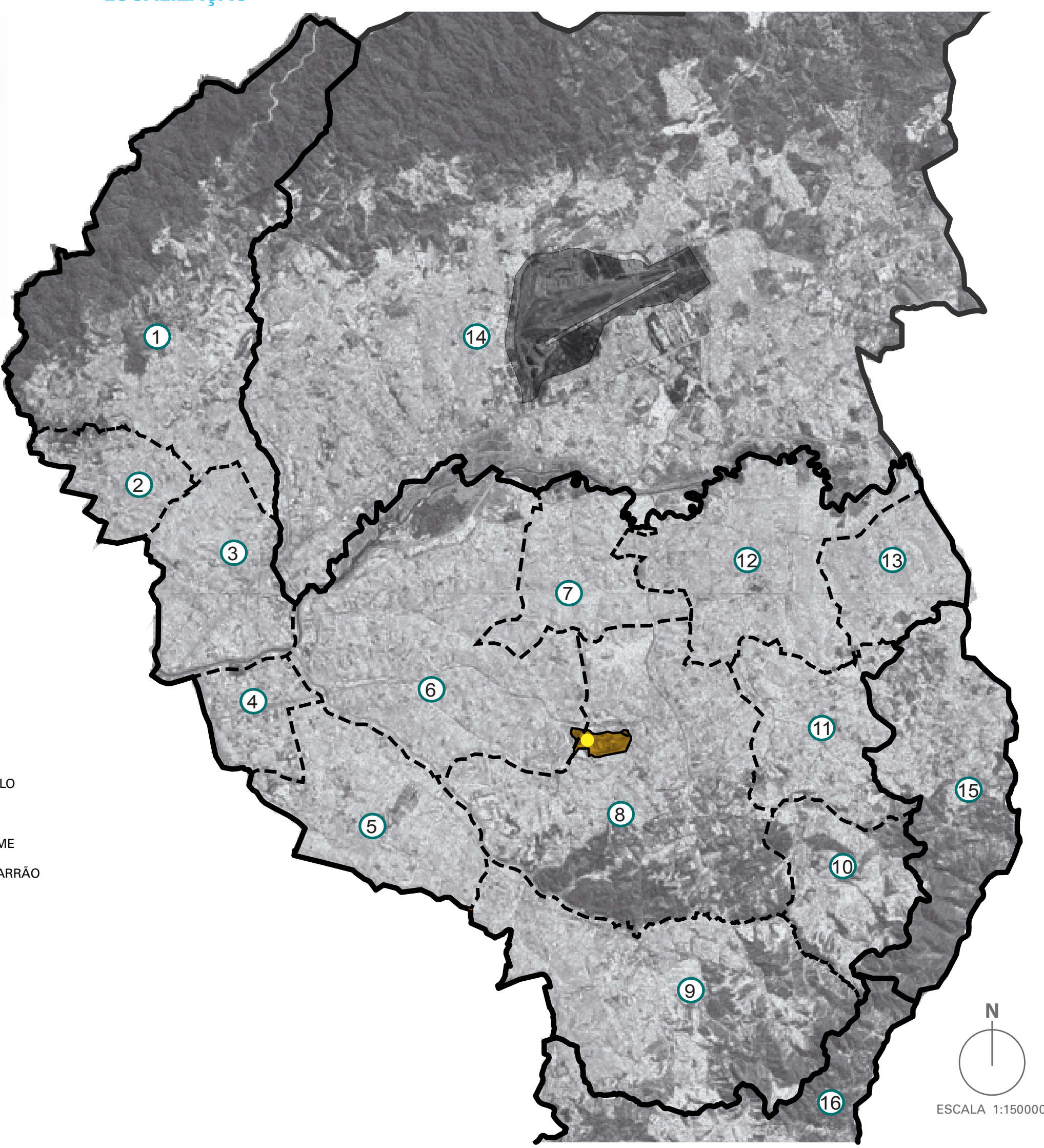

Figura 83: Localização da Arena Corinthians e sua área de influência entre a Serra da Cantareira, a APA do Carmo, e a Serra do Mar. Fonte: Prefeitura de São Paulo: http://infocidade.prefeitura.sp.gov.br/mapas/3_localizacao_do_municipio_de_sao_paulo_2013_10294.pdf. Base: Mapa Digital da Cidade, SMDU, Prefeitura de São Paulo, 2004. Mapeamento: Patricia Akinaga. Imagem de satélite: Google Earth, 2011 


\section{GEOLOGIA}

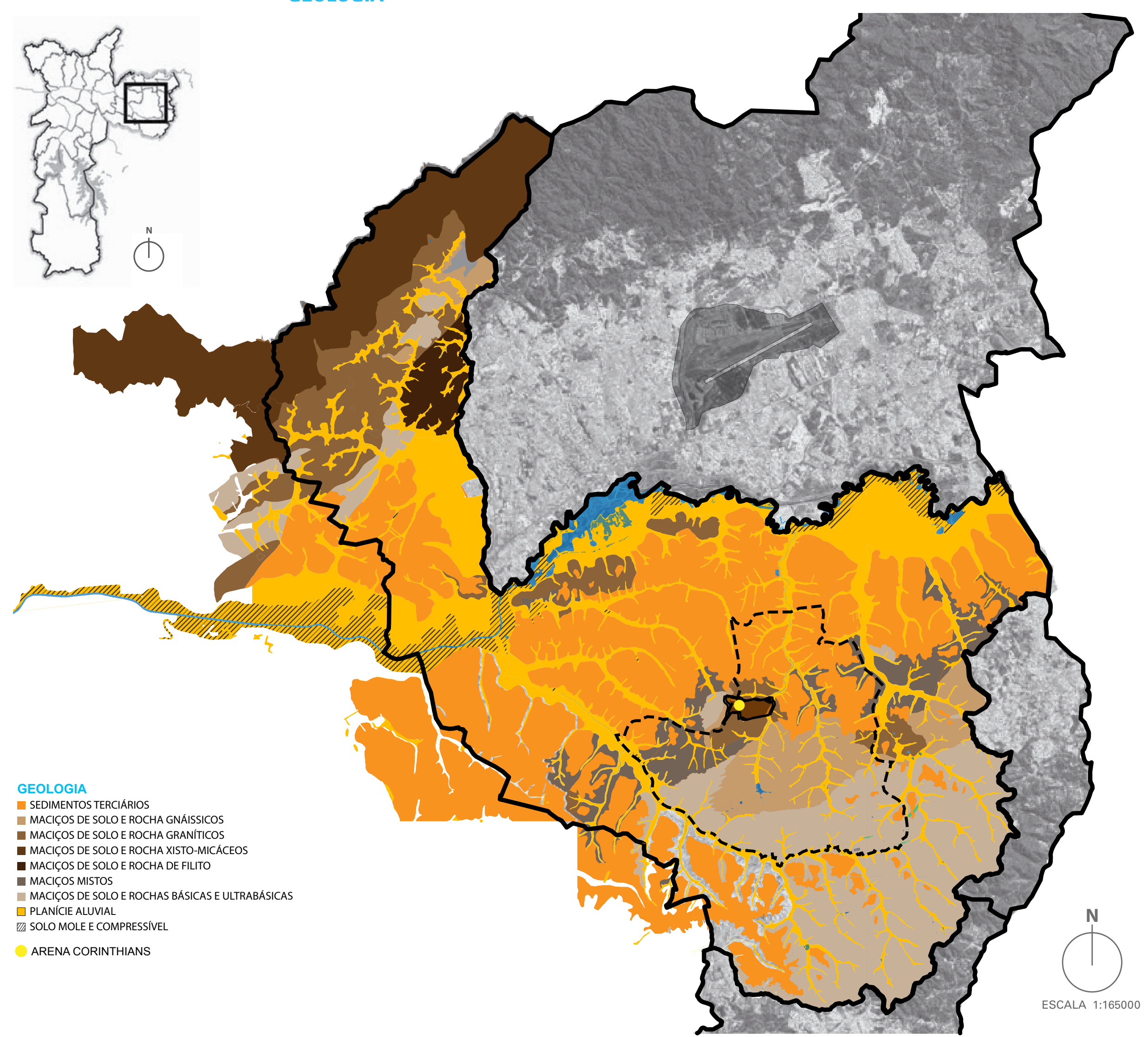

Figura 84: Estrutura geológica da área. Base: Mapa Digital da Cidade, SMDU, Prefeitura de São Paulo, 2004. Mapeamento: Patricia Akinaga. Imagem de satélite: Google Earth, 2011. 


\section{HIDROGRAFIA}
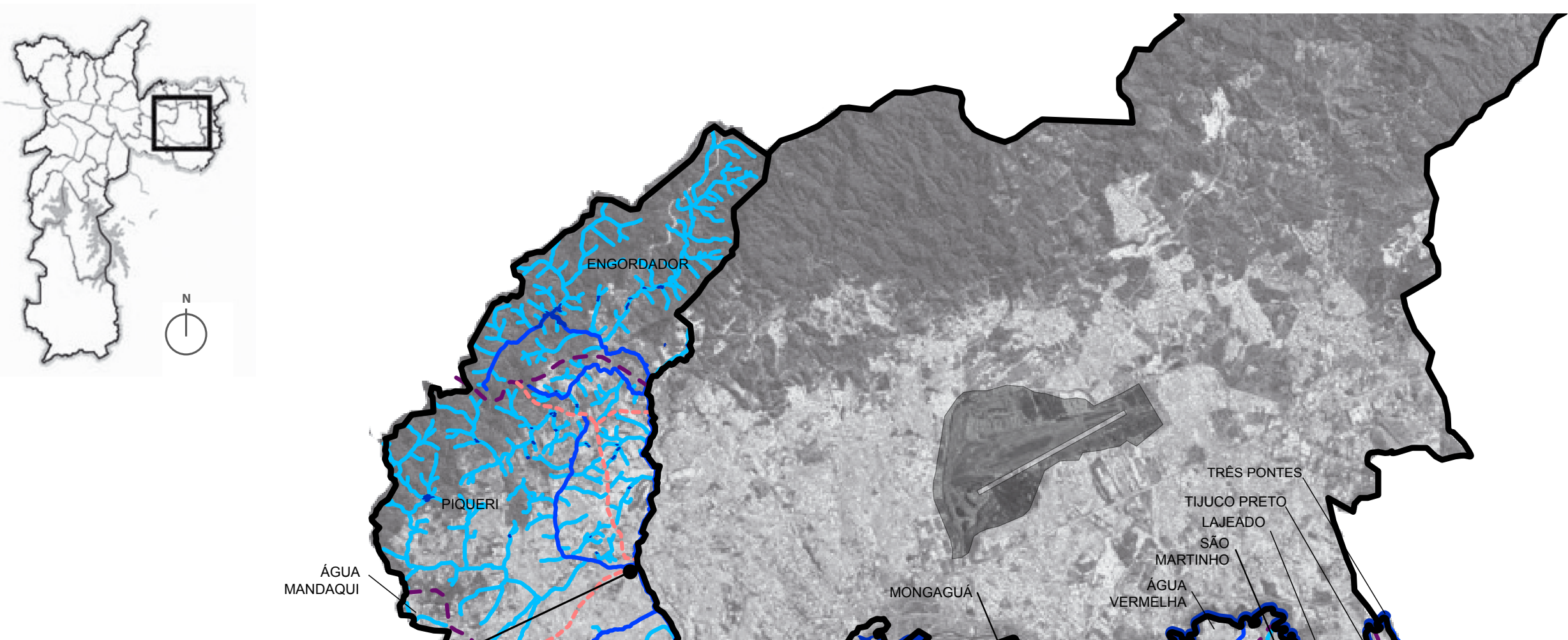

HIDROGRAFIA

- RIOS PRINCIPAIS E ALAGAMENTOS

- RIOS SECUNDÁRIOS E AFLUENTES

CORREGOS

- SUB-BACIAS (BROCADO CABUCU DE CIMA, PACIÉNCIA, GUAIÚNA)

ARENA CORINTHIANS

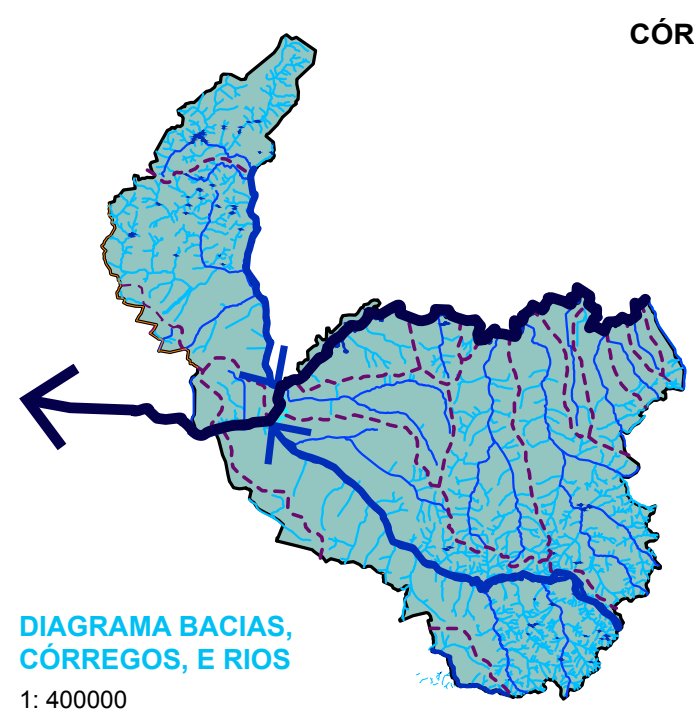

CÓRREGO GUAIÚNA

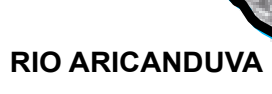

$$
\text { CARANDIRU }
$$

RIO TIETE

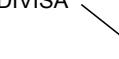

RIO ARICANDUVA

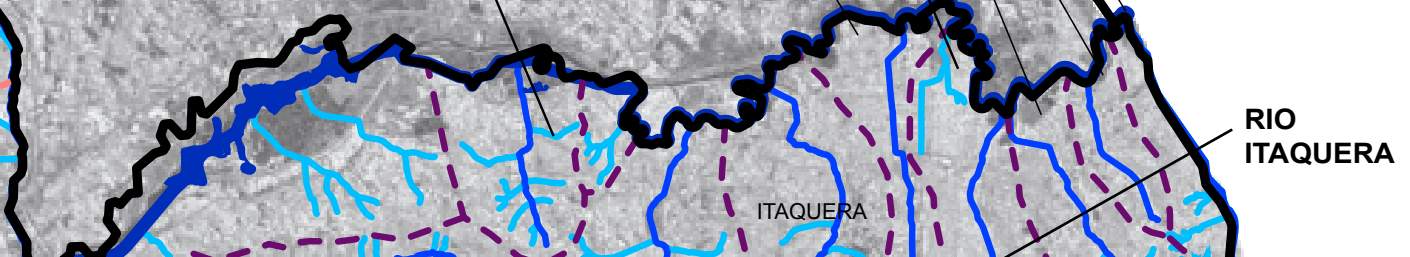
prefeitura.sp.gov.br/mapas/2_bacias_hidrograficas_2012_10651.pdf. Base: Mapa Digital da Cidade, SMDU, Prefeitura de São Paulo, 2004. Mapeamento: Patricia Akinaga. Imagem de satélite: Google Earth, 2011. 
A área do entorno da Arena Corinthians é caracterizada pela presença de muitos cursos d'água, alguns canalizados e outros verdadeiros canais de esgoto a céu aberto. Algumas chácaras, herança da época de formação do bairro, resistem próximas à APA do Carmo e outras isoladas no tecido urbano. Com a implantação da Arena Corinthians, a transformação urbana é inevitável, catalisada pelas obras viárias e pelo interesse crescente do paulistano pela região, desde que foi eleita sede da abertura da Copa do Mundo FIFA 2014.

Segundo os empreendedores da Arena Corinthians, ela potencializará a transformação de seu entorno através da atração de visitantes e do apelo aos residentes da área por seu aspecto multifuncional. É certo que houve a valorização imobiliária do bairro e muitos terrenos já foram alvos de especulação. A transformação gera oportunidades para se pensar uma nova forma de ocupação baseada nos conceitos de Crescimento Inteligente, Urbanismo Paisagístico e Urbanismo Ecológico, em que a paisagem é fator determinante para a configuração do desenho urbano, com a implantação de uma infraestrutura verde de alto desempenho, constituída de áreas verdes contínuas.

O impacto da implantação da arena reflete-se na criação de um sistema viário projetado para o automóvel, inadequado para a escala do pedestre e do usuário do transporte público. Como conciliar a necessidade de mobilidade com os atributos naturais existentes, para criar uma ocupação urbana comprometida com a qualidade ambiental e de vida?

Como já mencionado, a área do entorno da Arena é predominantemente residencial, densamente povoada e é caracterizada por condomínios de baixa renda e autoconstrução nas margens dos córregos do bairro (figura 86). O Parque do Carmo constitui-se em uma das áreas verdes mais importantes do bairro e da cidade, no entanto, é um grande fragmento isolado de outras áreas verdes como o Parque Ecológico doTietê e a Serra da Cantareira. Com os novos investimentos, a arborização urbana poderia ser melhorada e o tecido urbano mais diversificado, a fim de prover as necessidades básicas da população sem que ela precisasse se deslocar grandes distâncias aos centros de compras e empregos. 


\section{USO DO SOLO EXISTENTE}

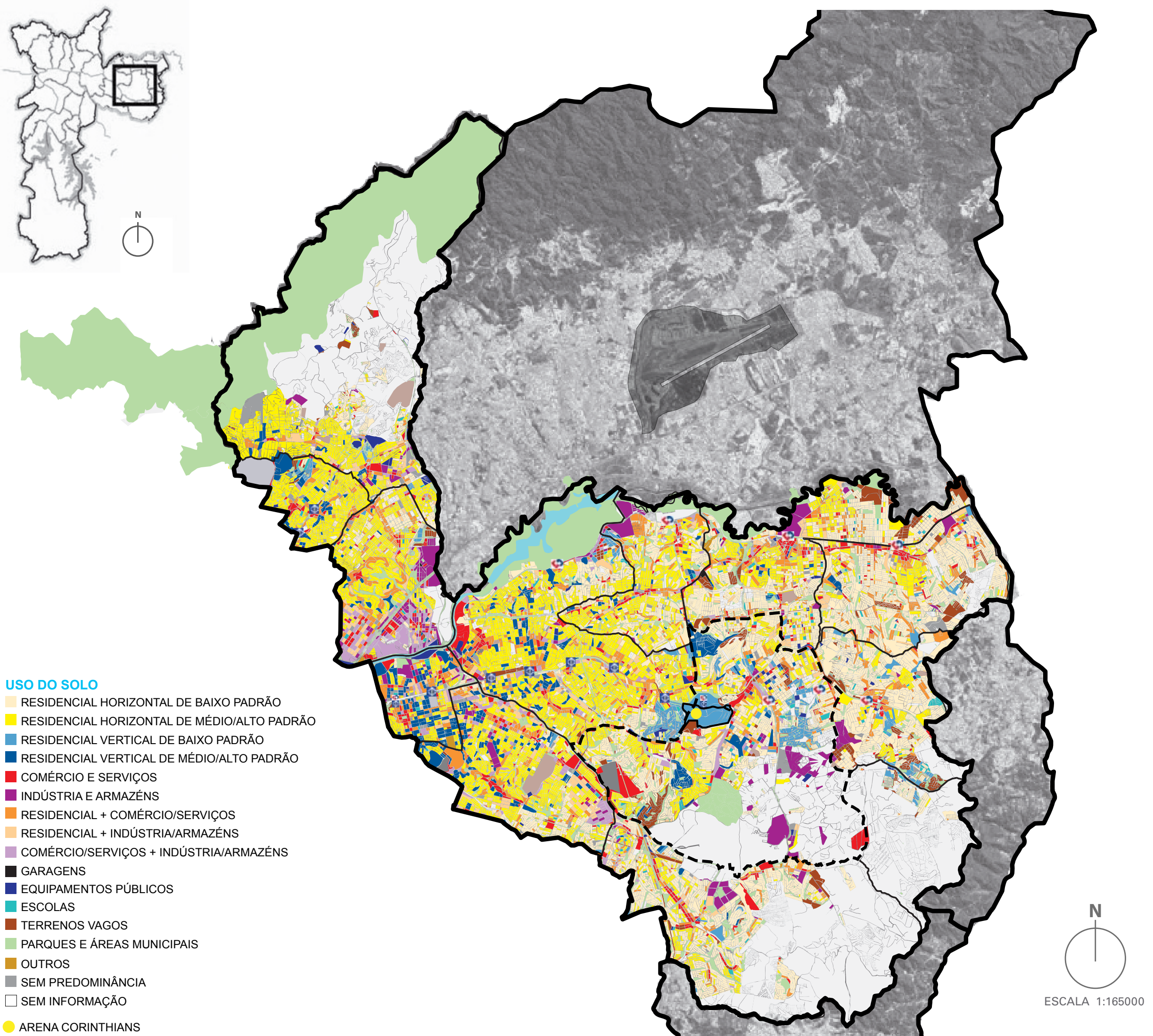

Figura 86: Uso de solo da área de influência da Arena Corinthians. Fonte: Prefeitura de São Paulo: Mapa do Uso do Solo Predominante, 2005, http://sempla.prefeitura.sp.gov.br/mm/panorama/pdf/pag06.pdf. Base: Mapa Digital da Cidade, SMDU, Prefeitura de São Paulo, 2004. Montagem: Patricia Akinaga. Imagem de satélite: Google Earth, 2011 
Promover o Urbanismo Ecológico em um tecido urbano consolidado é difícil e oneroso, mas a oportunidade de transformação gerada pela implantação da Arena apresenta-se como estudo de caso válido para se provar a tese de que a implementação do Urbanismo Ecológico em São Paulo é possível, bem como a melhoria da qualidade de vida urbana através da aplicação de seus princípios.

O perímetro estabelecido para a área a ser focada neste trabalho baseou-se nas características do uso do solo, nas áreas verdes significativas como a Serra da Cantareira, ao norte e a APA do Carmo, ao sul, com a complementação da área compreendida entre a APA e o limite com o município de Itaquaquecetuba, onde se encontra parte da Serra do Mar e na área de influência da Arena Corinthians, estabelecida pelas distâncias possíveis a serem percorridas a pé com abrangência em escalas denominadas: pequena, a uma distância de 1,6 km do centro da Arena Corinthians (20 minutos de caminhada), média, $5 \mathrm{~km}$ do centro da Arena (60 minutos de caminhada) e a macroescala, que engloba a área compreendida entre a Serra da Cantareira (2,5 horas de caminhada do centro da Arena) e a APA do Carmo (ver Figura 87).

Com base no mapa de geologia elaborado pela Prefeitura de São Paulo, verifica-se na macroescala que há domínio das planícies aluviais, constituídas na área do entorno da Arena Corinthians pelos rios Cabuçu, Tietê, Tiquatira, Guaiúna, Aricanduva, Verde, Itaquera e Jacu. O sistema viário principal da área estrutura-se a partir destes vales, o que resultou na canalização de boa parte destes cursos d'água, como por exemplo, o Aricanduva.Tal sistema apresenta-se como potencialidade de conexão entre os fragmentos verdes existentes (figura 88).

Dentro da área de estudo há grandes espaços subutilizados e assentamentos precários (figura 89) que potencialmente poderiam se transformar em novas âncoras da infraestrutura verde, juntamente com as áreas verdes existentes como a Serra da Cantareira, o Parque Ecológico Tietê e a APA do Carmo (figura 90), conectadas pela arborização viária e jardins de chuva a serem criados nas vias (figura 91). 


\section{EQUIPAMENTOS URBANOS E A ÁREA DE INFLUÊNCIA DA ARENA CORINTHIIANS}

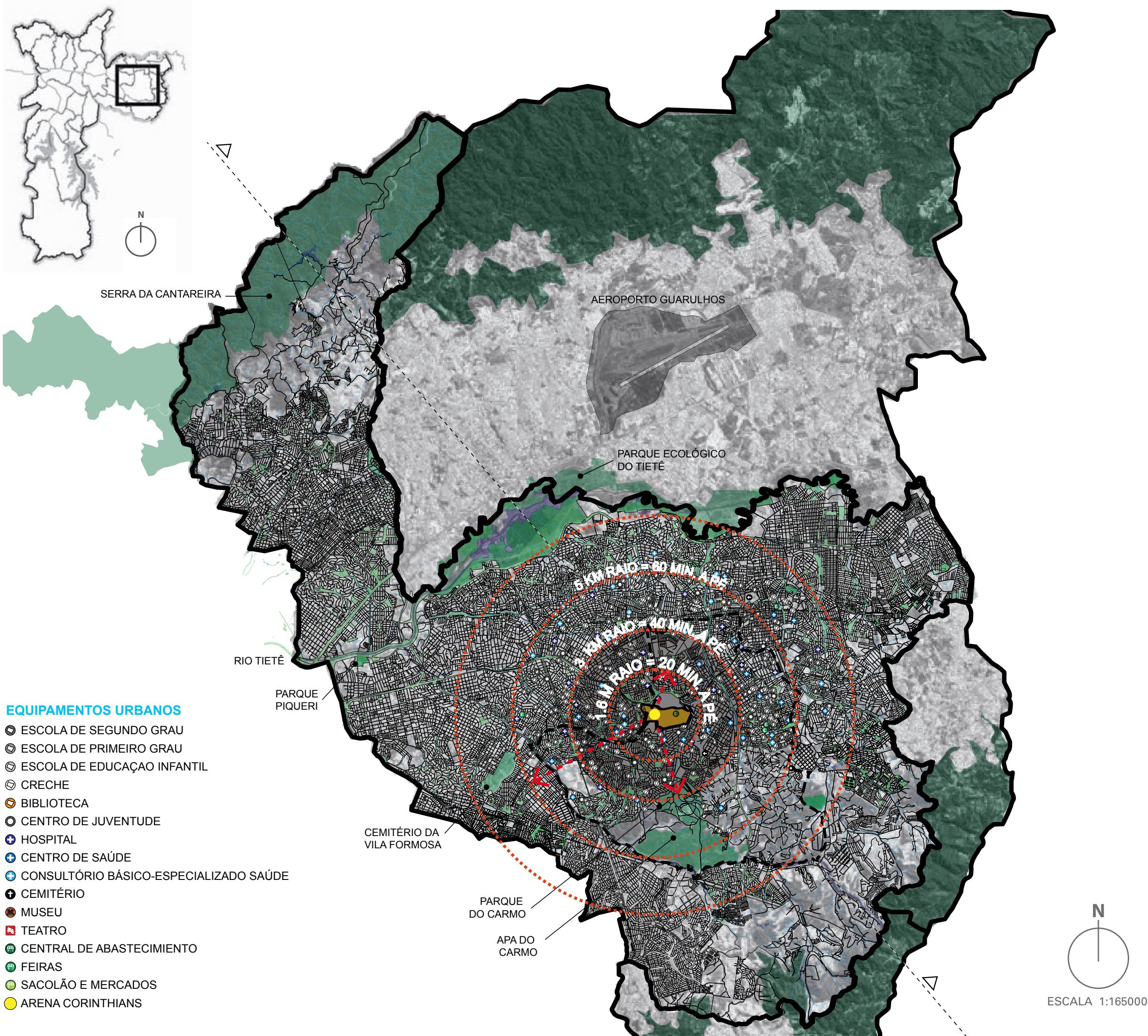

Figura 87: Área de influência da Arena Corinthians. Fonte: Prefeitura de São Paulo: Mapa de Equipamentos Sociais, 2006: http:// sempla.prefeitura.sp.gov.br/mm/panorama/pdf/pag05.pdf. Base: Mapa Digital da Cidade, SMDU, Prefeitura de São Paulo, 2004. Diagrama:

Patricia Akinaga. Imagem de satélite: Google Earth, 2011 


\section{SISTEMA DE TRÂNSITO E TRANSPORTE}

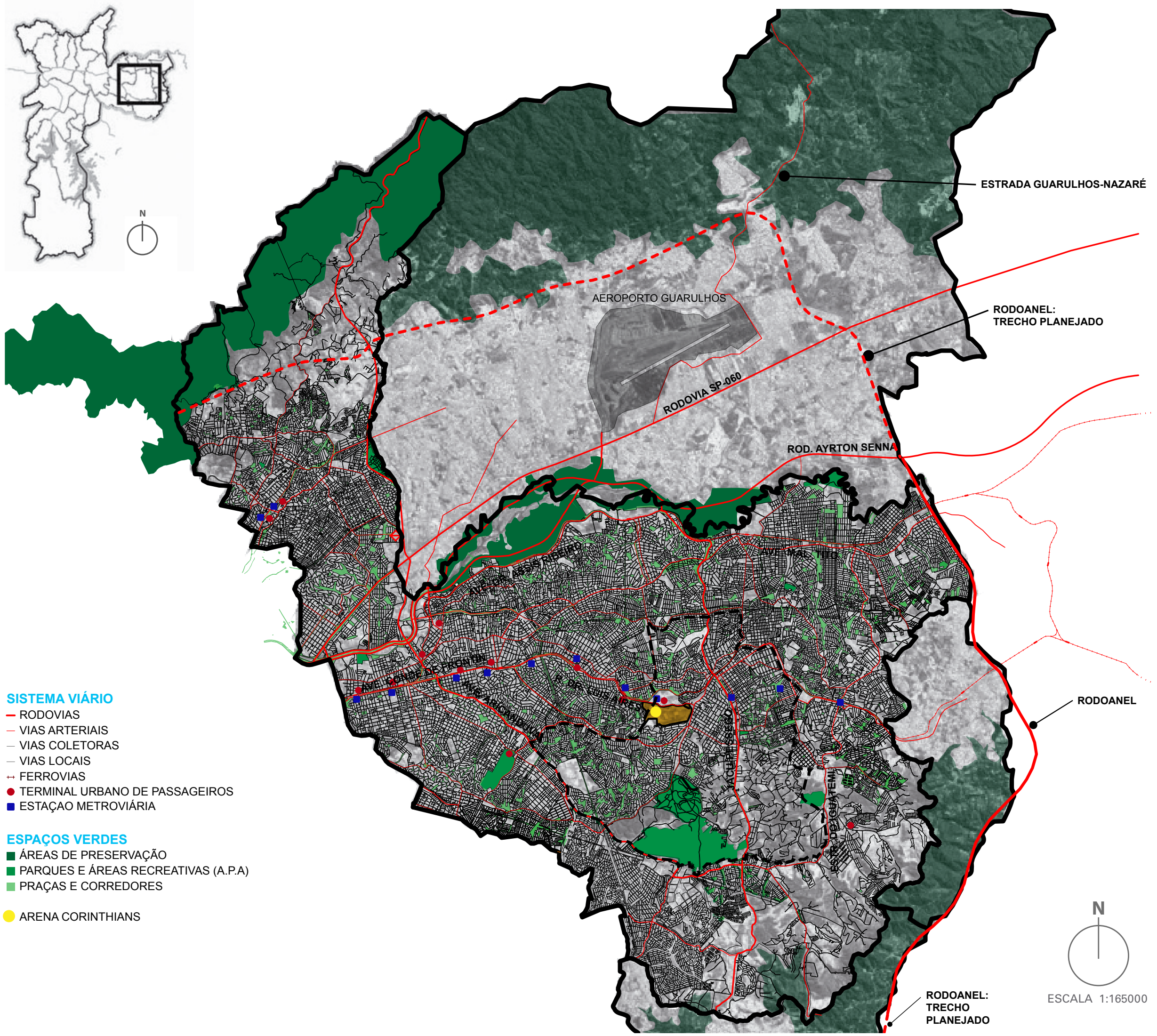

Figura 88: Potencialidades do sistema de trânsito e tranporte como eixos de conexão dos espaços verdes existentes. Base: Mapa Digital da Cidade, SMDU, Prefeitura de São Paulo, 2004. Mapeamento: Patricia Akinaga. Imagem de satélite: Google Earth, 2011 


\section{ESPAÇOS SUBUTILIZADOS}
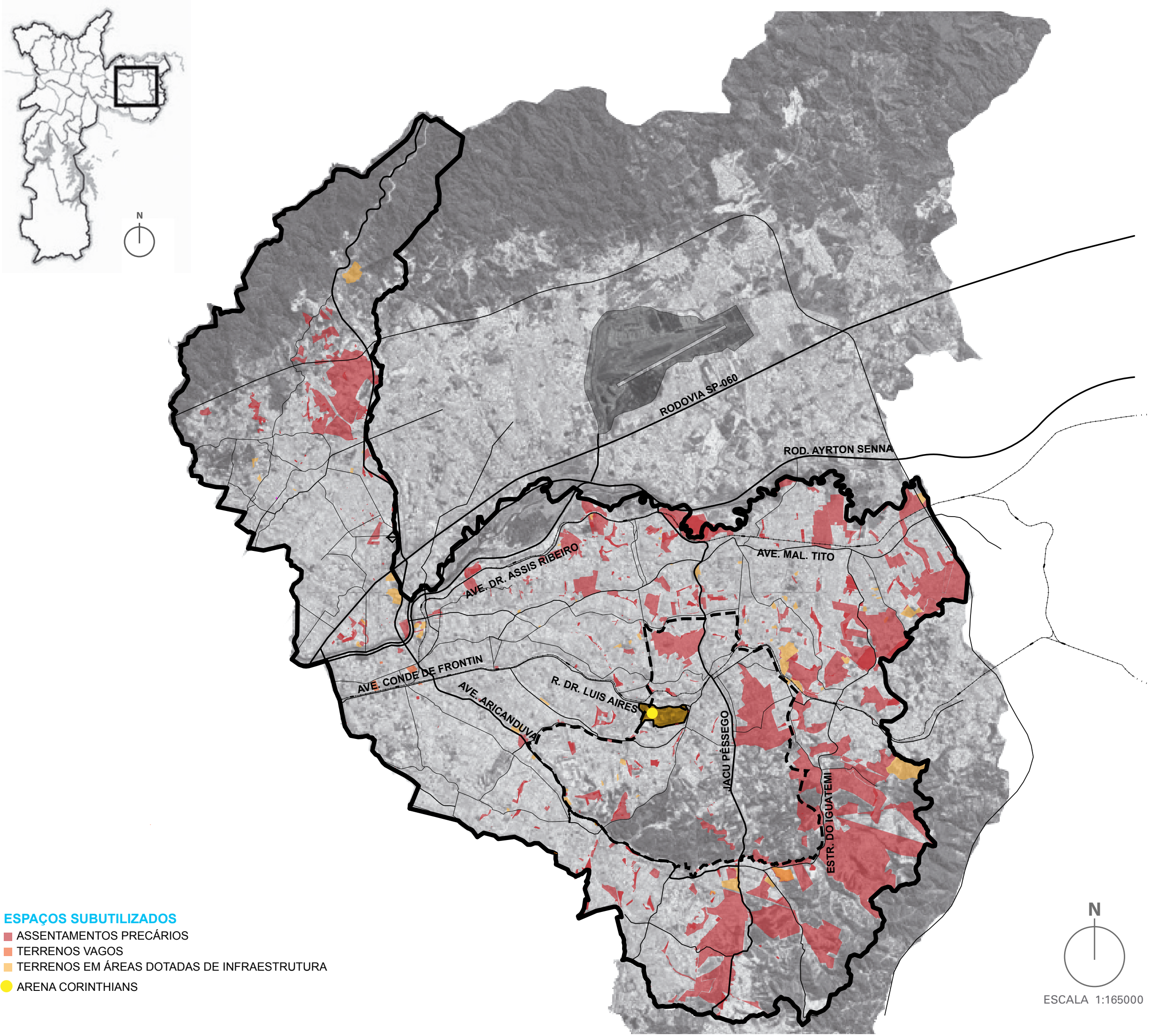

ESPACOOS SUBUTILIZADOS

ASSENTAMENTOS PRECÁRIOS

- TERRENOS VAGOS

TERRENOS EM ÁREAS DOTADAS DE INFRAESTRUTURA

ARENA CORINTHIANS

Figura 89: Espaços subutilizados presentes na área de estudo. Base: Mapa Digital da Cidade, SMDU, Prefeitura de São Paulo, 2004. Mapeamento: Patricia Akinaga. Imagem de satélite: Google Earth, 2011 


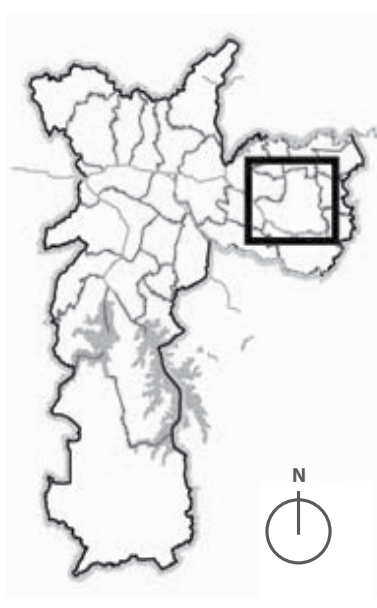

\section{ÁREAS VERDES EXISTENTES FRAGMENTADAS}

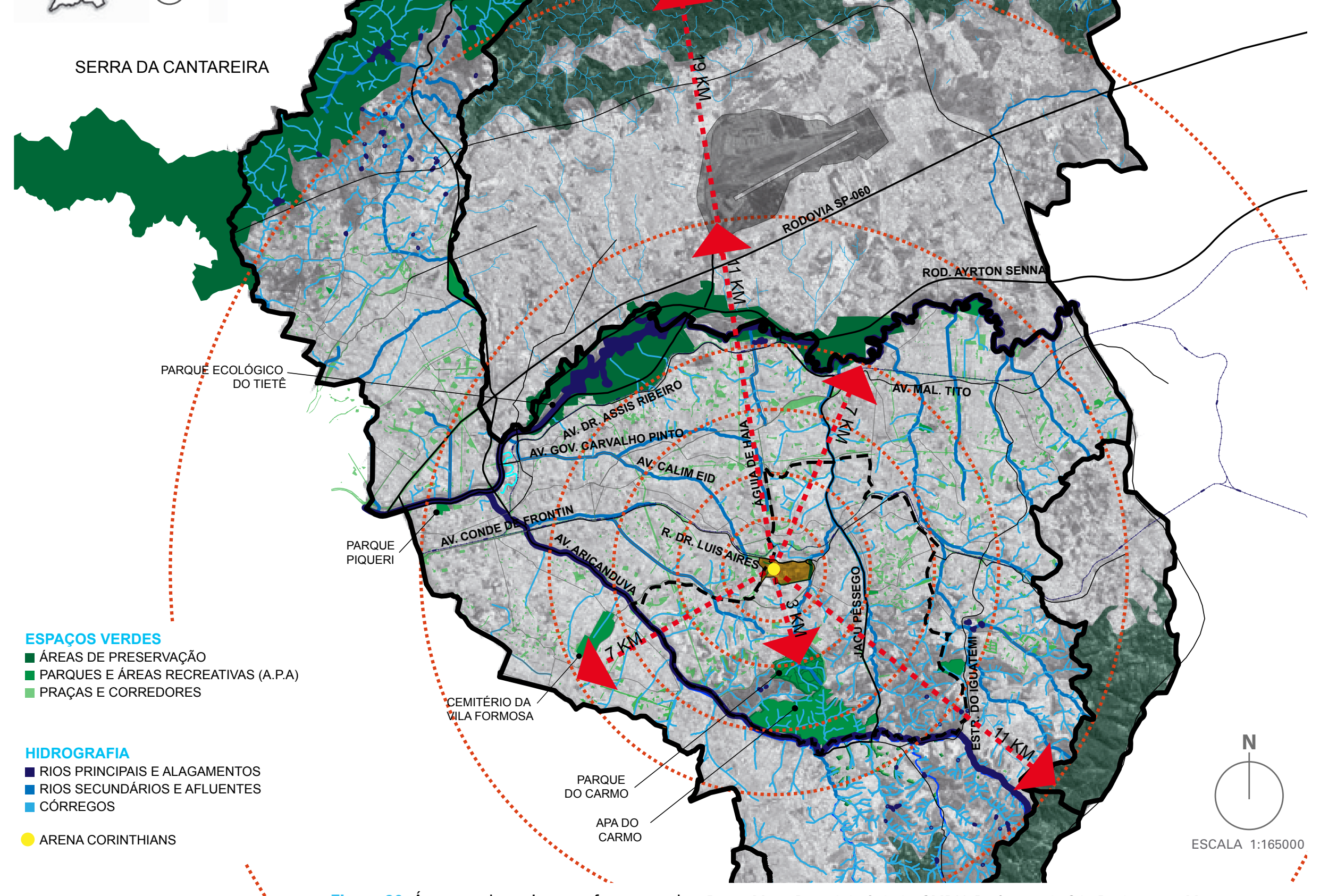

Figura 90: Áreas verdes existentes fragmentadas. Base: Mapa Digital da Cidade, SMDU, Prefeitura de São Paulo, 2004. Mapeamento: Patricia Akinaga. Imagem de satélite: Google Earth, 2011 


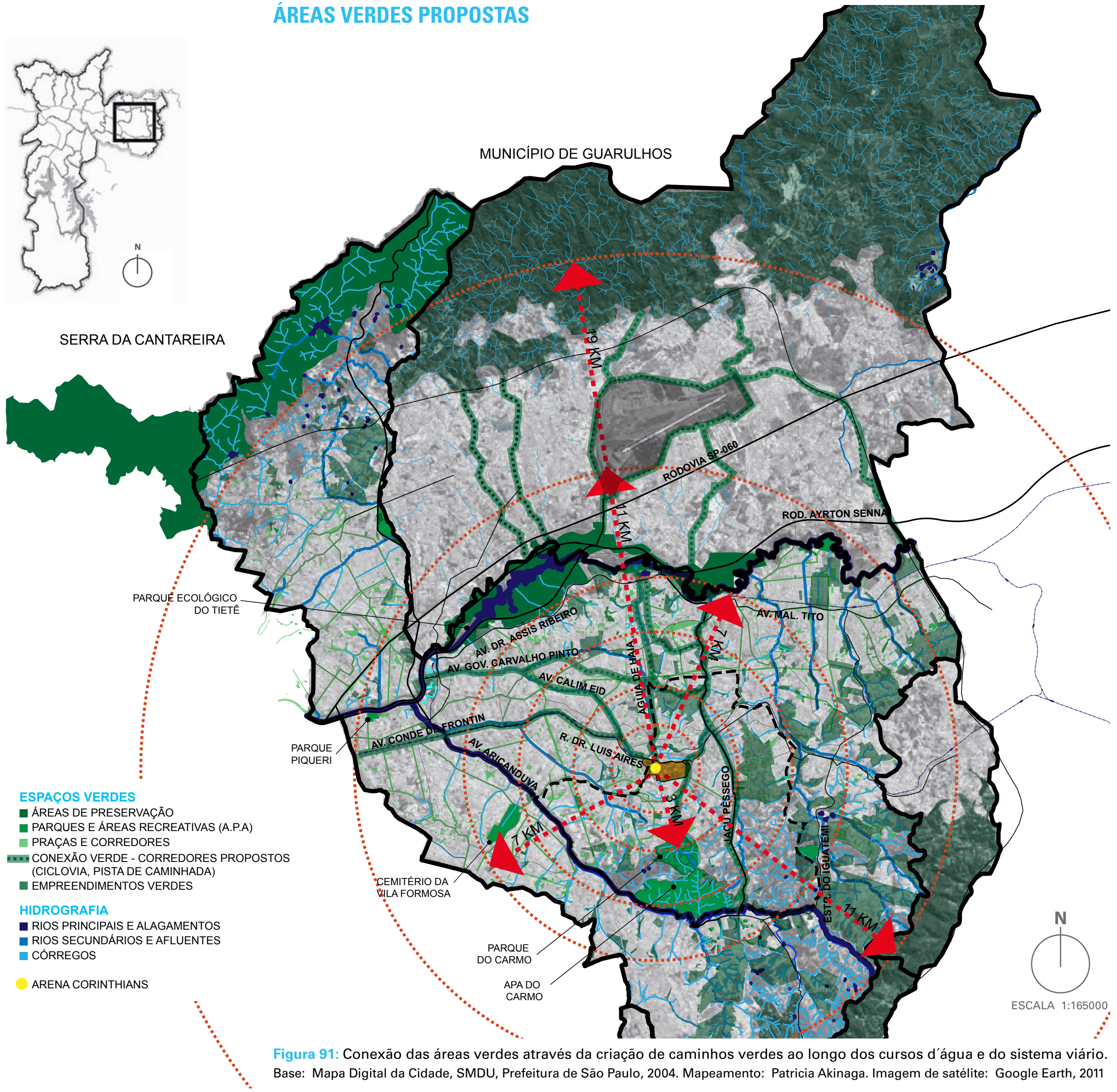


A proposta desta pesquisa é transformar os cursos d'água em elementos importantes de uma rede de infraestrutura verde a ser implantada no entorno da Arena, com a criação de uma série de caminhos verdes nas margens dos córregos e nas vias da área de estudo, com a inserção de jardins de chuva, ciclovias e passeios largos e amplamente arborizados. Como exemplos, são propostos protótipos nas ruas Itaquera (figura 92) e na Rua Doutor Luis Aires (figura 93).

Também se propõe a conversão dos terrenos vagos e subutilizados da área em empreendimentos mistos e espaços públicos verdes como áreas de recreação, lazer e educação ambiental, através da implantação de programas como, por exemplo, jardins comunitários em diversas escalas que promovem cidadania como já demonstrado na experiência do programa P-Patch de Seattle e de algumas escolas estaduais de São Paulo.

Há o potencial de conexão da Serra da Cantareira com a APA do Carmo através dos corredores verdes propostos, tendo como resultado uma ocupação urbana mais equilibrada com os recursos naturais existentes. Os pequenos espaços verdes projetados nos terrenos subutilizados têm a função de promover a transformação da qualidade de vida na escala da rua e posteriormente do bairro. Atualmente não há conexão entre as áreas verdes existentes como verificado na ilustração do transepto (figura 94). A imagem do transepto proposto (figura 95) ilustra a situação pretendida com a configuração de uma nova infraestrutura verde.

Como fase inicial, adota-se a ocupação das áreas vazias no entorno do estádio, como modelo para as demais, ou seja, as áreas compreendidas no polo institucional com a transformação de estacionamentos de superfície em edifícios garagem para liberação de espaços livres destinados à criação de áreas verdes e lagos de retenção.

Toma-se como premissa o desenvolvimento econômico do bairro, a partir da geração local de empregos, catalisada pela arena multiuso, pelo polo institucional e pelos novos negócios deslocados de outras zonas da cidade para a Zona Leste, durante e após a Copa, estimulados pelo valor da terra ainda atrativo e pela melhoria de acessibilidade. Este processo foi verificado em Los Angeles e São Francisco com a implantação de suas respectivas arenas, como mencionado no capítulo 6. 


\section{VISUALIZAÇÃO: ANTES E DEPOIS}

\section{PERSPECTIVA 01}

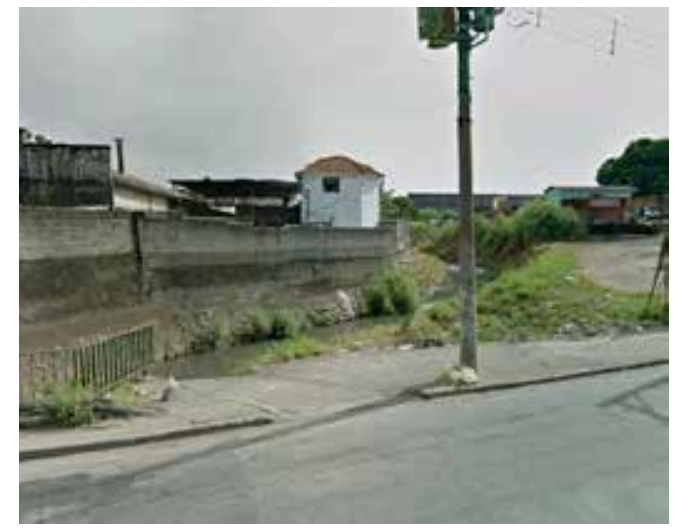

A: Antes
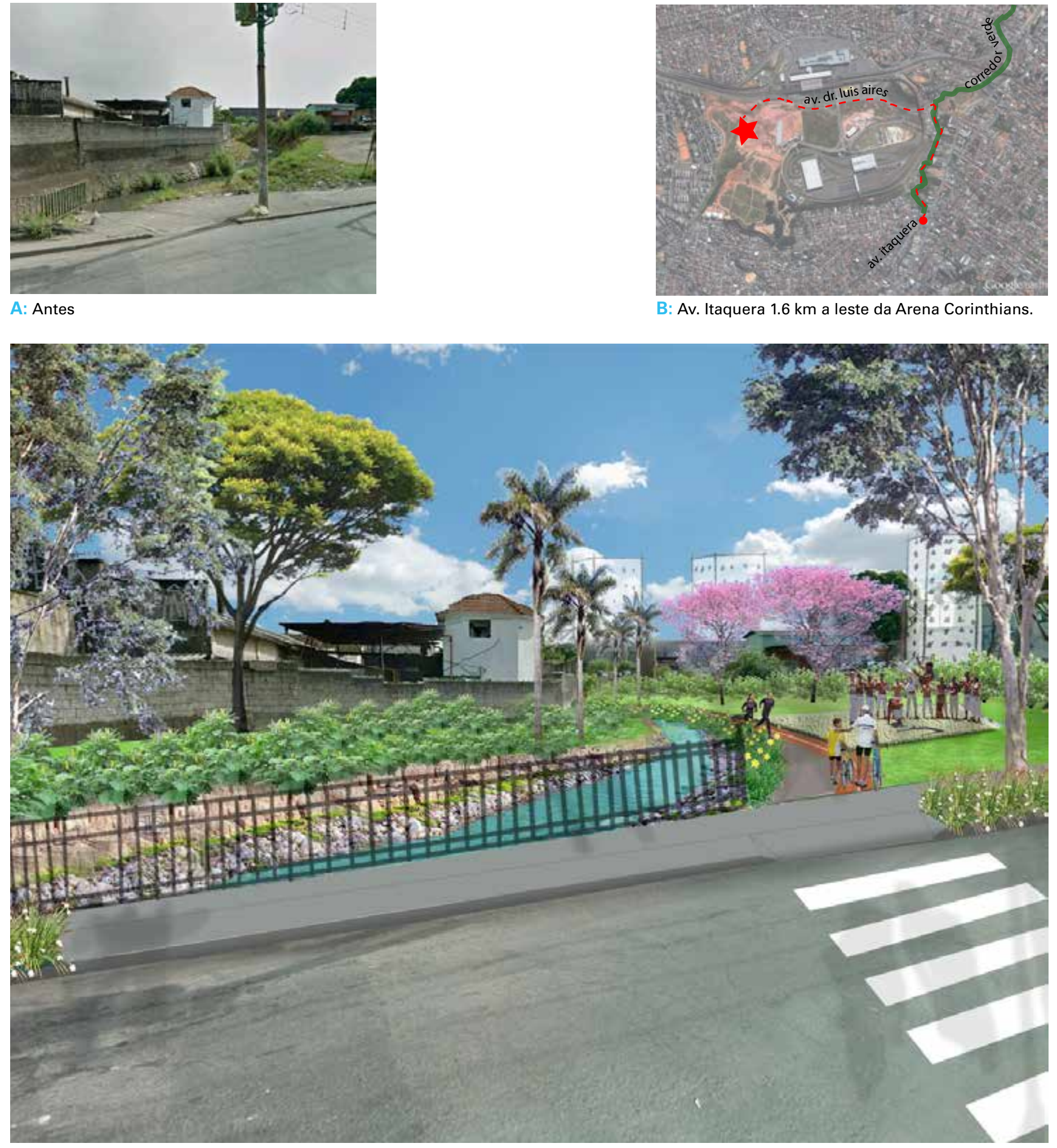

C: Depois

Figura 92: Caminho verde ao longo da Rua Itaquera. Ilustração: Patricia Akinaga Arquitetura Paisagística e Desenho Urbano Imagem de satélite: Google Earth, 2011. 


\section{VISUALIZAÇÃO: ANTES E DEPOIS}

\section{PERSPECTIVA 02}

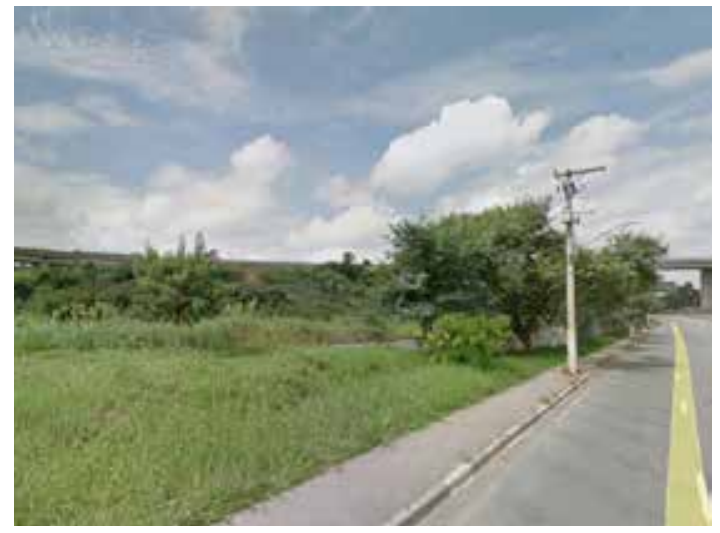

A: Antes

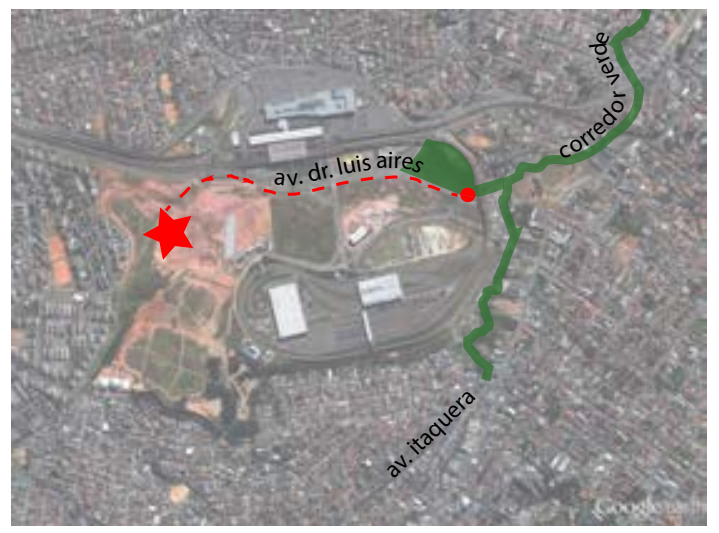

B: R. Doutor Luis Aires, $1 \mathrm{~km}$ a leste da Arena Corinthians.

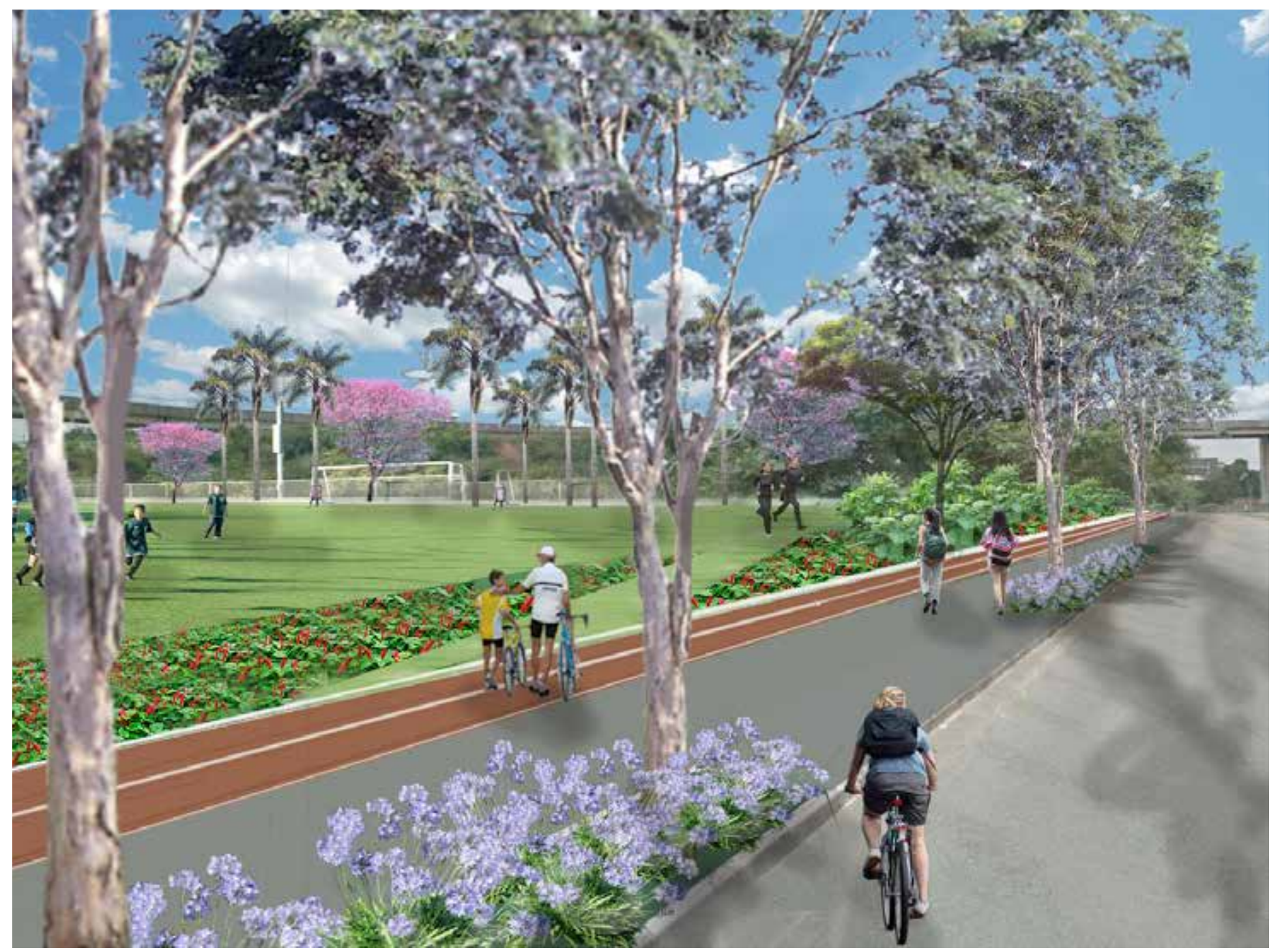

C: Depois

Figura 93: Área verde proposta ao longo da Rua Dr. Luis Aires. Ilustração: Patricia Akinaga Arquitetura Paisagística e Desenho Urbano. Imagem de satélite: Google Earth, 2011. 


\section{TRANSEPTO - SITUAÇÃO EXISTENTE}

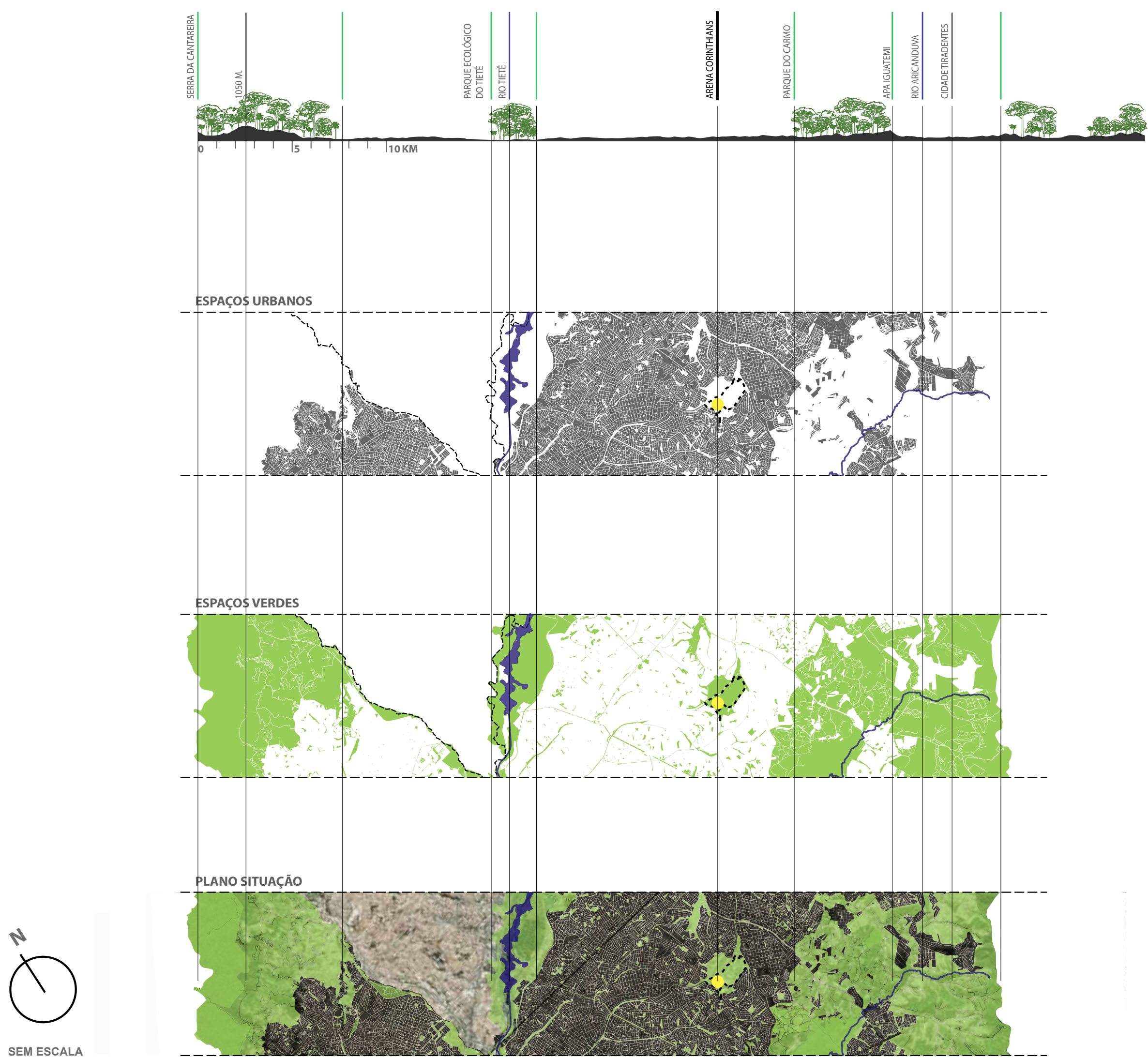

Figura 94: Transepto da situação existente: áreas verdes fragmentadas sem conexão. Base: Mapa Digital da Cidade, SMDU, Prefeitura de São Paulo, 2004. Mapeamento e transepto: Patricia Akinaga. Imagem de satélite: Google Earth, 2011 


\section{TRANSEPTO - SITUAÇÃO PROPOSTA}

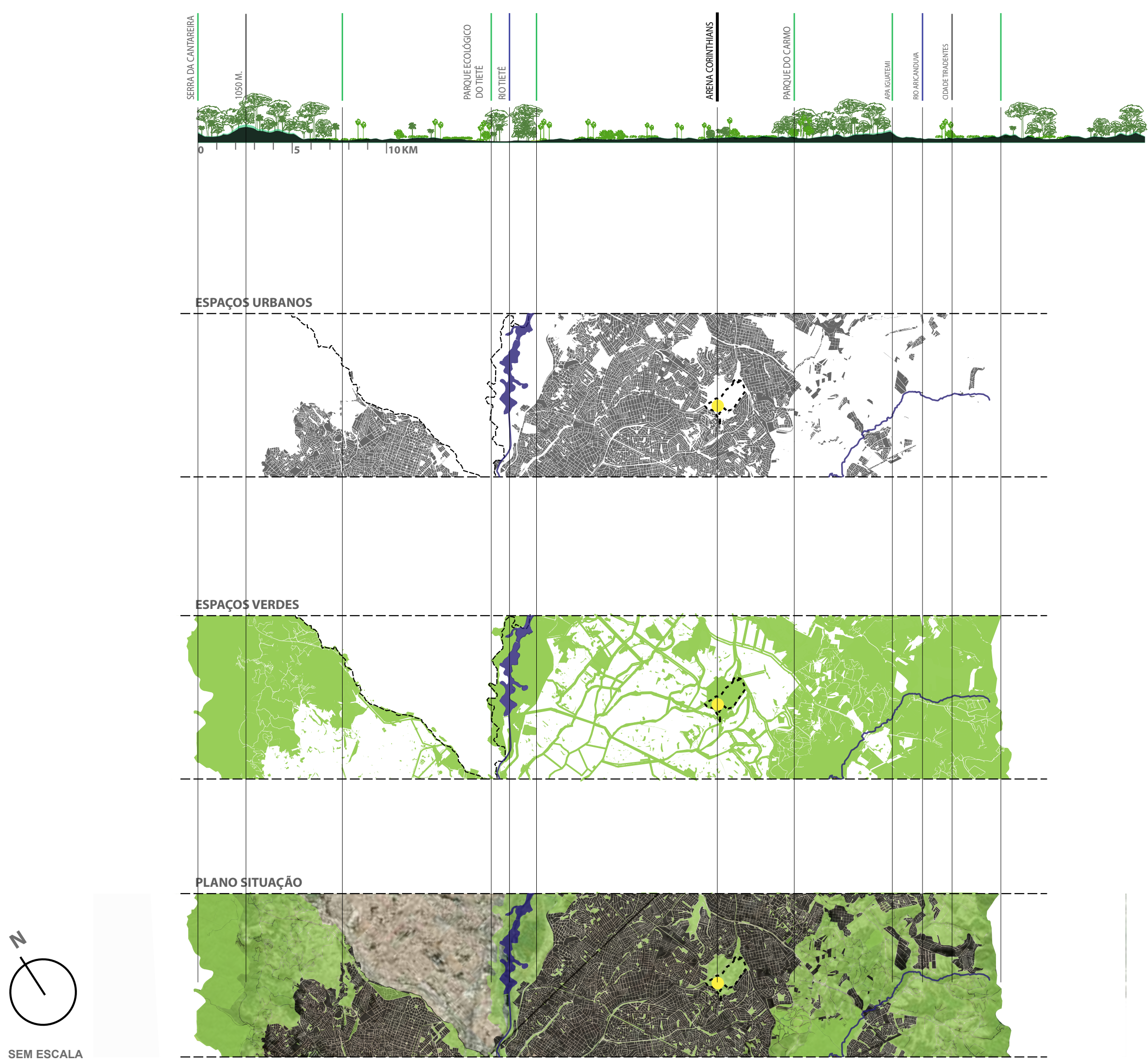

Figura 95: Infraestrutura verde proposta. Base: Mapa Digital da Cidade, SMDU, Prefeitura de São Paulo, 2004. Mapeamento e transepto: Patricia Akinaga. Imagem de satélite: Google Earth, 2011 
Não se trata de um projeto de curto prazo, mas com a incorporação de diretrizes do Urbanismo Ecológico no Plano Regional da Subprefeitura de Itaquera, que sofrerá alterações com a revisão do Plano Diretor, pode-se vislumbrar a sua viabilidade e a concretização da proposta em realidade para Itaquera e em paradigma para São Paulo, comprometida com a visão do Plano da SP 2040, da megalópole sustentável.

Para a análise da média escala, o método utilizado foi o da inserção das condições existentes como equipamentos urbanos, espaços subutilizados, ocupação urbana, sistema de trânsito e transporte e espaços verdes em camadas para entender suas dinâmicas na área de $5 \mathrm{~km}$ de raio do centro da Arena Corinthians. Verificou-se a articulação possível entre a hidrografia, o sistema viário, a malha urbana e os espaços verdes, tendo como resultado uma infraestrutura verde a partir da qual se pode estruturar uma ocupação segundo diretrizes do Urbanismo Ecológico (figura 96).

A análise em escala local, delimitada por uma área de 1,6 km de raio, distância percorrida em 20 minutos a partir do centro da Arena, mostra o potencial da área com a existência de cursos d'água, áreas verdes fragmentadas, terrenos vagos, lotes subutilizados e um sistema viário estruturado pelas várzeas (figura 97).

Hortas comunitárias de dimensões variáveis poderiam ser implantadas na escala local em terrenos vagos, subutilizados ou áreas verdes existentes, como demonstrado na figura 98. Estas hortas assumem o papel de elementos da infraestrutura verde, além de incrementar as áreas verdes do bairro, promover a educação ambiental e a cidadania como já demonstrado no projeto dos jardins comunitários em Seattle, objeto do capítulo 4 desta tese.

A hidrografia existente em Itaquera cria as condições ideais para a implantação de um sistema natural de drenagem, já estudado no capítulo 5, que contribui para a qualidade ambiental do bairro de forma significativa através dos jardins de chuva. O sistema viário, com a substituição gradual da infraestrutura tradicional, terá sua paisagem alterada bem como a sua dinâmica ecológica que favorecerá a recuperação do habitat local. Aliada à ação de despoluição de todos os córregos, como prevê o Plano SP 2040, esta infraestrutura verde torna-se parte fundamental do Urbanismo Ecológico (figura 99 e 100). 


\section{CAMADAS}

EQUIPAMENTOS URBANOS - ESCOLA DE SEGUNDO GRAU - ESCOLA DE EDUCAÇAO INFANTIL Q CRECHE

- BIBLIOTECA
- CENTRO DE JUVENTUDE - CENTRO

- HOSPITAL

- CONSULTÓRIO BÁSICO-ESPECIALIZADO SAÚDE - CEMITERIO

O MUSEU

๑ CENTRAL DE ABASTECIMIENTO

SẼO

ESPACOS SUBUTILIZADOS

$\square$ QUADRAS URBANA

ASSENTAMENTOS PRECÁRIOS

- TERRENOS VAGOS

TERRENOS EM AREAS DOTADAS

DE INFRAESTRUTURA

OCUPAÇÃO

口MALHA URBANAS

SISTEMA DE TRÂNSITO

E TRANSPORTE

- RODOVIAS

- VIAS ARTERIAIS

\#FERROVIAS

$\rightarrow$ TERMINAL URBANO DE PASSAGEIROS

- ESTAÇAO METROVIÁRIA

ESPAÇOS VERDES + HIDROGRAFIA

- ÁREAS DE PRESERVAÇÃO

- PARQUES E ÁREAS RECREATIVAS (A.P.A)

促

- RIOS SECUNDÁRIOS EAFLUENTES

- CÓRREGOS

LEGENDA

ARENA CORINTHIANS

\section{ESTUDOS NA MÉDIA ESCALA}

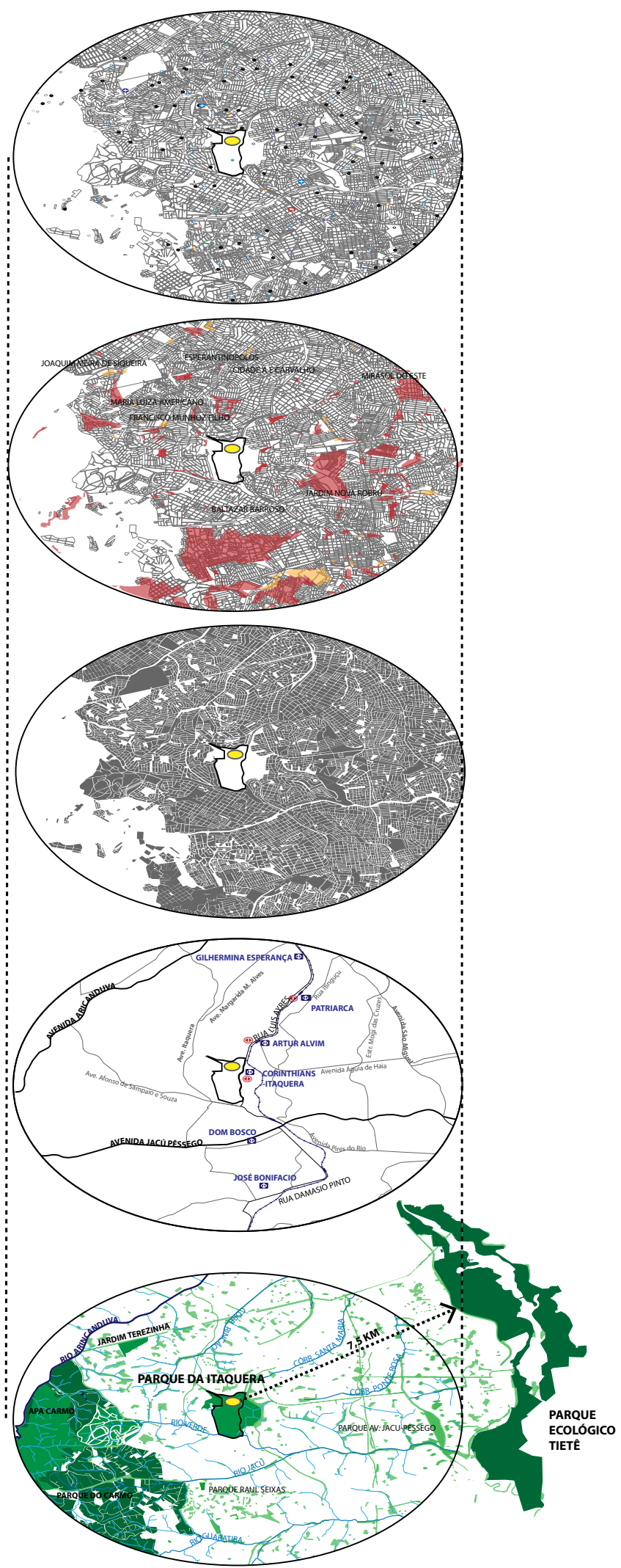

CRIAÇÃO DA INFRAESTRUTURA VERDE

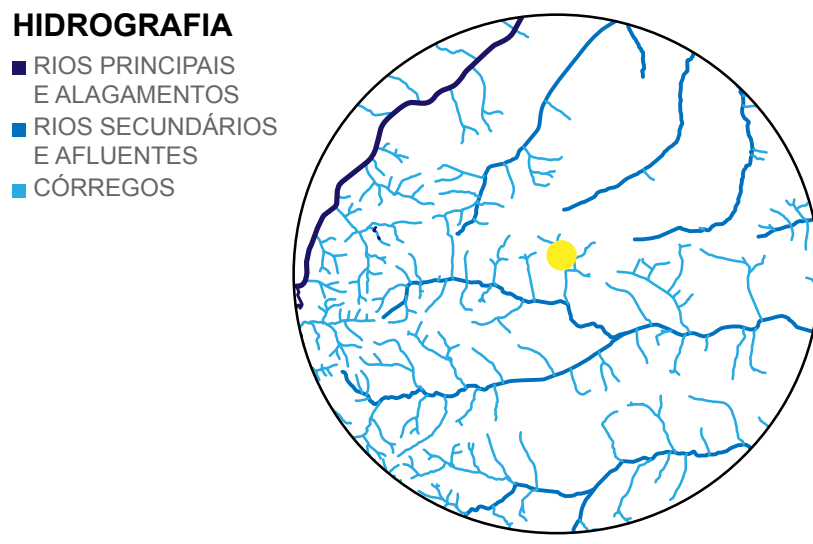

SISTEMA VIÁRIO

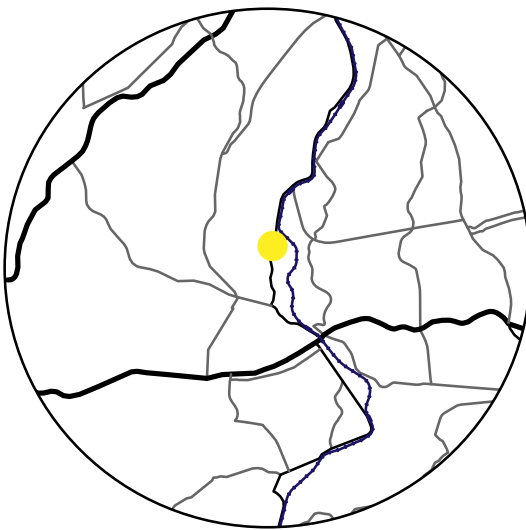

MALHA URBANA E ESPAÇOS URBANOS

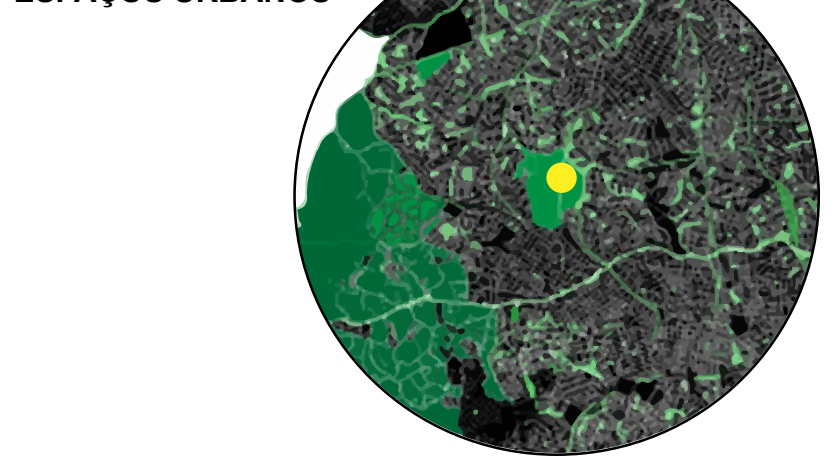

MALHA URBANA + ESPAÇOS VERDES +

HIDROGRAFIA + SISTEMA VIÁRIO

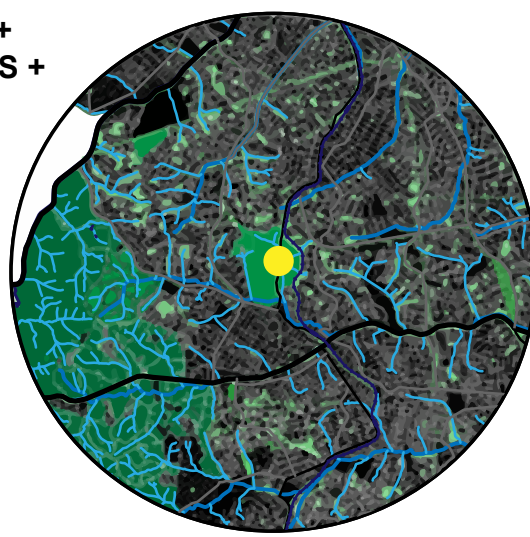

Figura 96: Análise das condições existentes em camadas e criação da infraestrutura verde no entorno da Arena Corinthians. Base: Mapa Digital da Cidade, SMDU, Prefeitura de São Paulo, 2004. Mapeamento: Patricia Akinaga. Imagem de satélite: Google Earth, 2011 


\section{CARÁTER DO BAIRRO EXISTENTE}

EQUIPAMENTOS URBANOS - ESCOLA DE SEGUNDO GRAU ESCOLA DE EDUCAÇAO INFANTIL ๑ CRECHE

- BIBLTTECA DUVENTUDE

-
- HOSPITAL
CENTRO DE SAÚDE

Q CONSULTÓRIO

O MUSEU

CENTRAL DE ABASTECIMIENTO - SAColÁo E MERCADOS

- AREAS DE PRESTES

- PARQUE E AREAS RECREATIVAS (A.P.A)

- RIOS PRINCIPAIS EALAGAMENTOS

- RIOS SECUNDARIOS EAFLUENTES

ARENA CORINTHIANS

ESCALA 1:50000

SISTEMA DE TRÂNSITO

TRANSPORT
SPAÇOS VERDES + HIDROGRAFIA
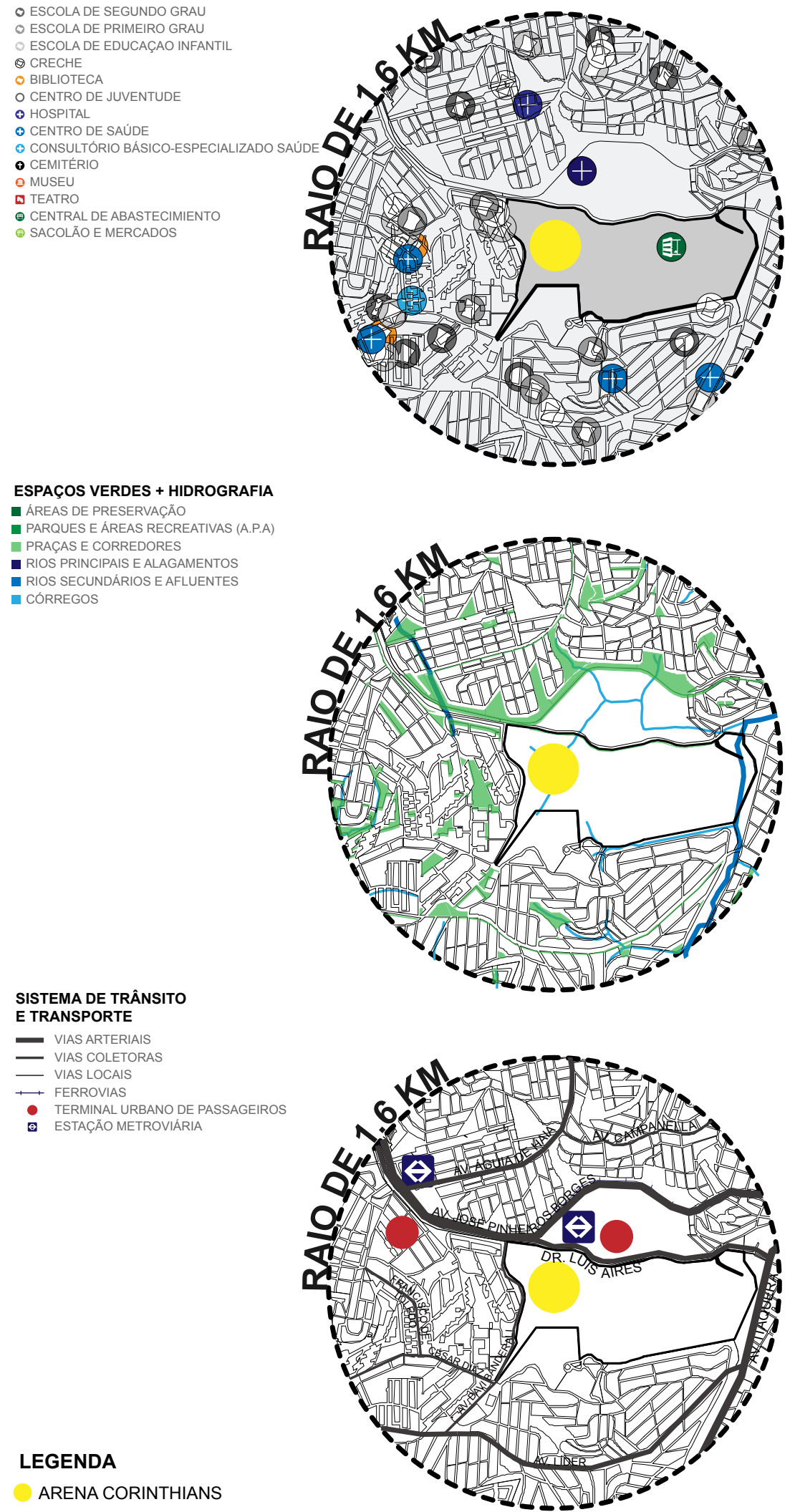

MANCHA URBANA

- QUASENTAMENTOS PRECARIOS

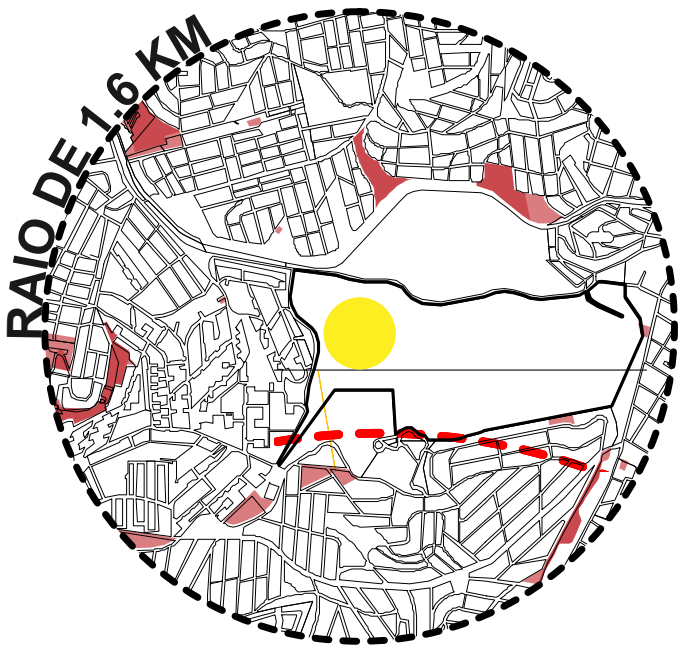

ANÁLISE TERRENOS/GABARITOS
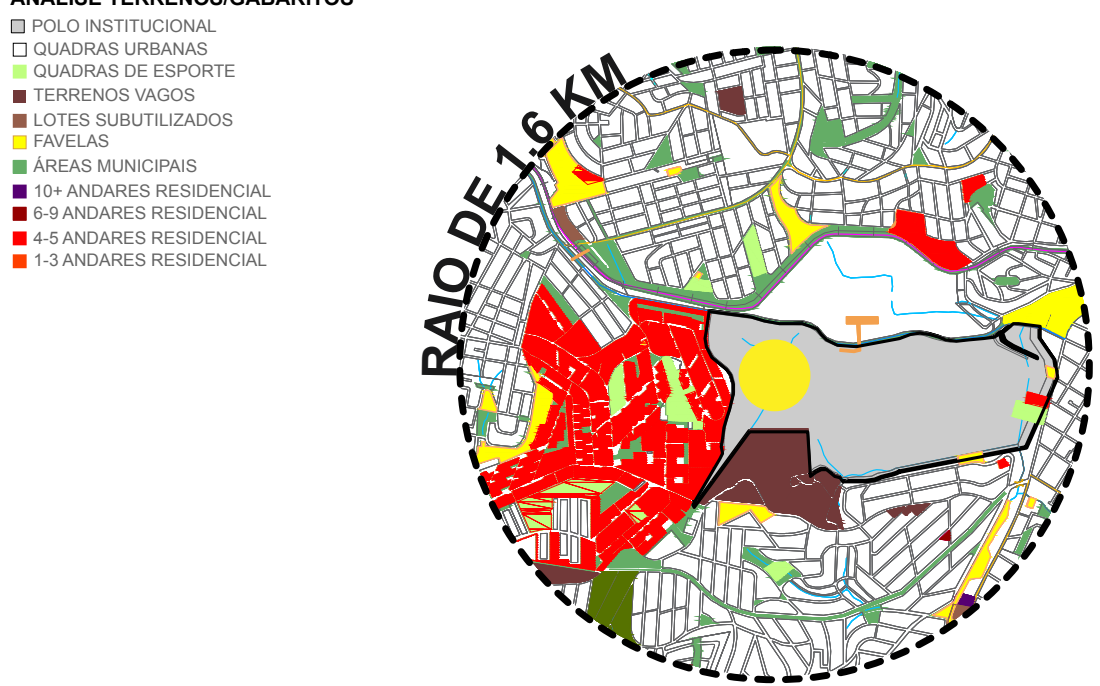

PLANO DIRETOR VIGENTE/USO DO SOLO LESIDENOR VIGENTE/USO DO SOLO RESIDENCIAL HORIZONTAL DE MÉDIO/ALTO PADRÃO RESIDENCIAL VERTICAL DE BAIXO PADRÃO - COMERCIO E SERVIÇCS INDÚSTRIA E ARMAZÉNS

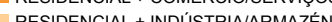

- GARAGENS

- ERUIPAMENTOS PÚBLICOS

ESCOLAS

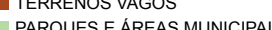

OUTROS

SEM PREDOMINÂNCIA

$\square$ SEM INFORMAÇÃO

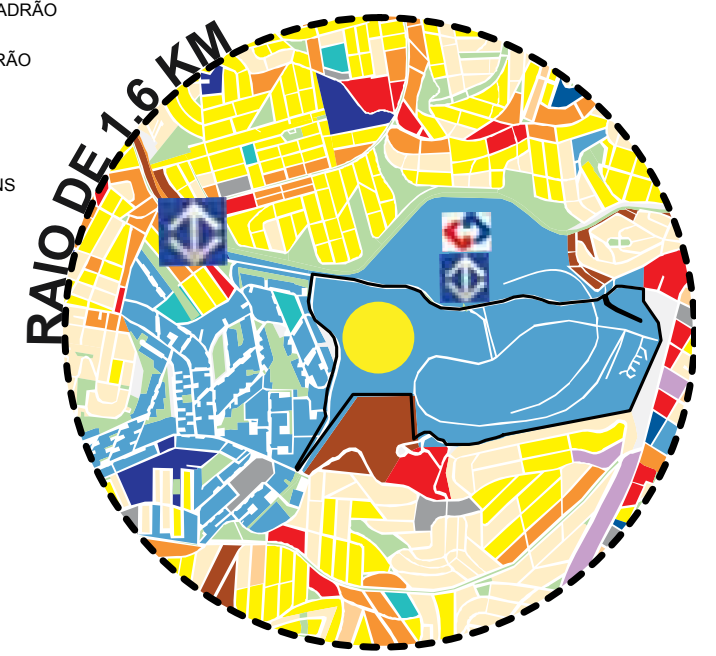

Figura 97: Análise das condições existentes em escala local 20 minutos de caminhada do centro da arena. Fonte: Prefeitura de São Paulo, Mapa do Uso do Solo Predominante, 2005: http://sempla.prefeitura.sp.gov.br/mm/panorama/pdf/pag06.pdf, http://sempla.prefeitura. sp.gov.br/mm/panorama/pdf/pag05.pdf. Base: Mapa Digital da Cidade, SMDU, Prefeitura de São Paulo, 2004. Mapeamento: Patricia Akinaga. 
LEGENDA

作

- RIOS SECUNDARIOS (ABERTOS)

- RIOS SECUNDÁRIOS CAMA IZADOS (ABERTOS) - uRIOS SECUNDÁrIos canalizados (SUBTERRÂNeO) - CORREGOS

ARENACORNTHANS

HORTA PEQUENA: $500 \mathrm{~m}^{2}$

POMAR DE 14 ARVORES

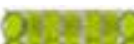

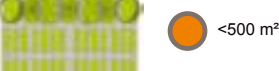

HORTA MÉDIA: $900 \mathrm{~m}^{2}$
56 CANTEIROS DE $4 \mathrm{~m}^{2}$

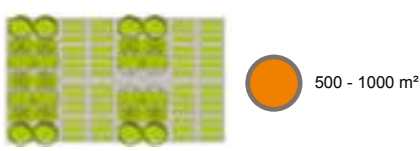

HORTA GRANDE: $3000 \mathrm{~m}^{2}$

168 CANTEIROS DE $4 \mathrm{~m}^{2}$

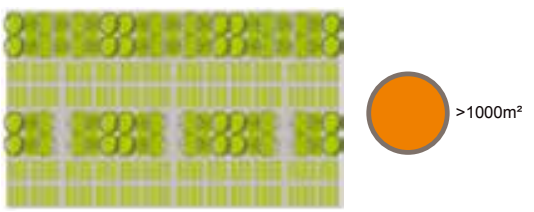

\section{HORTA COMUNITÁRIAS}

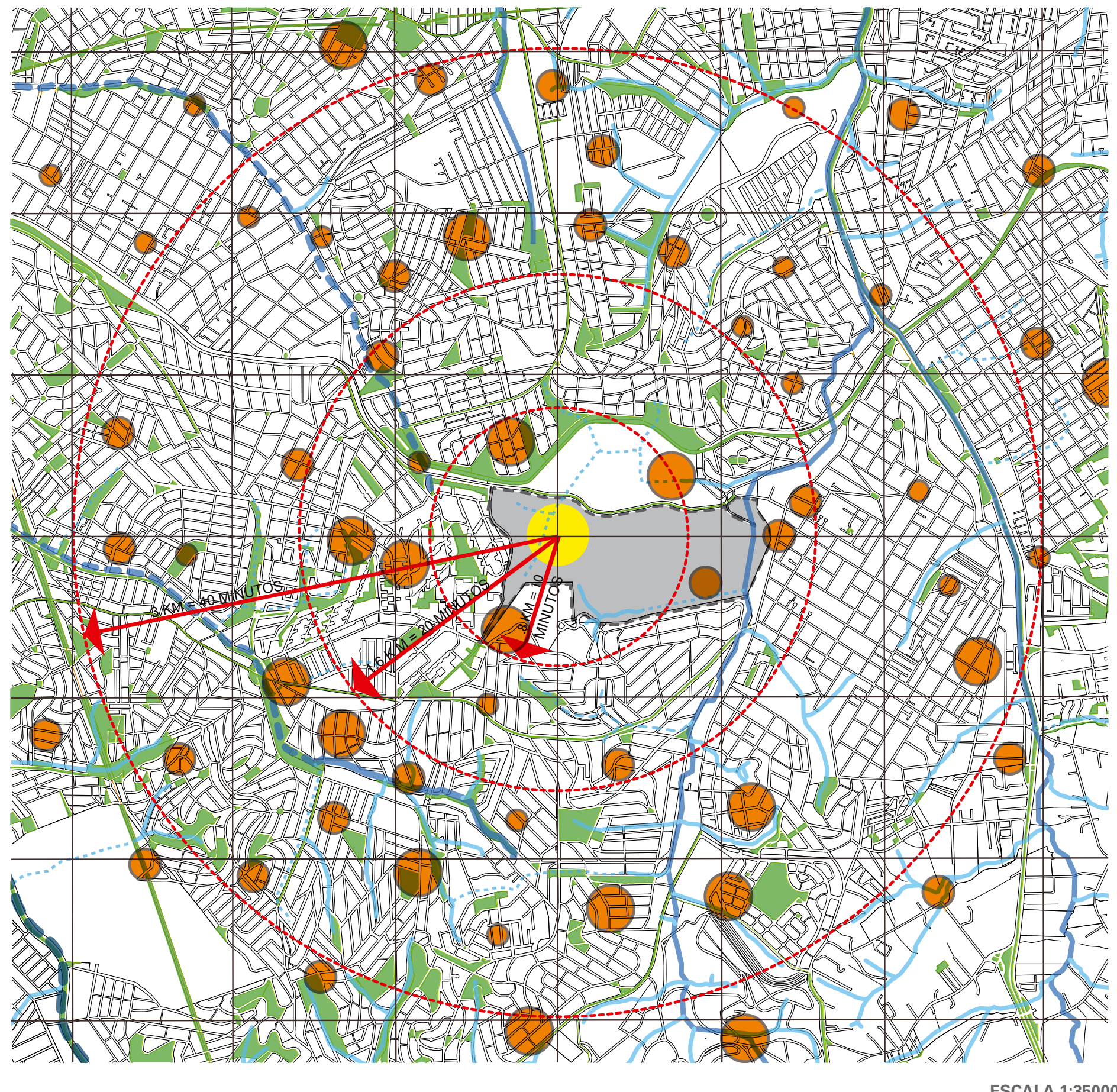

Figura 98: Hortas comunitárias como parte da infraestrutura verde e do urbanismo ecológico. Fonte: Urban Agriculture Guidelines for the Private Realm, Prefeitura de Vancouver, BC, Canadá, 2008: http://vancouver.ca/files/cov/urban-agriculture-guidelines.pdf. Base: Mapa Digital da Cidade, SMDU, Prefeitura de São Paulo, 2004. Mapeamento: Patricia Akinaga. 


\section{JARDINS DE CHUVA}

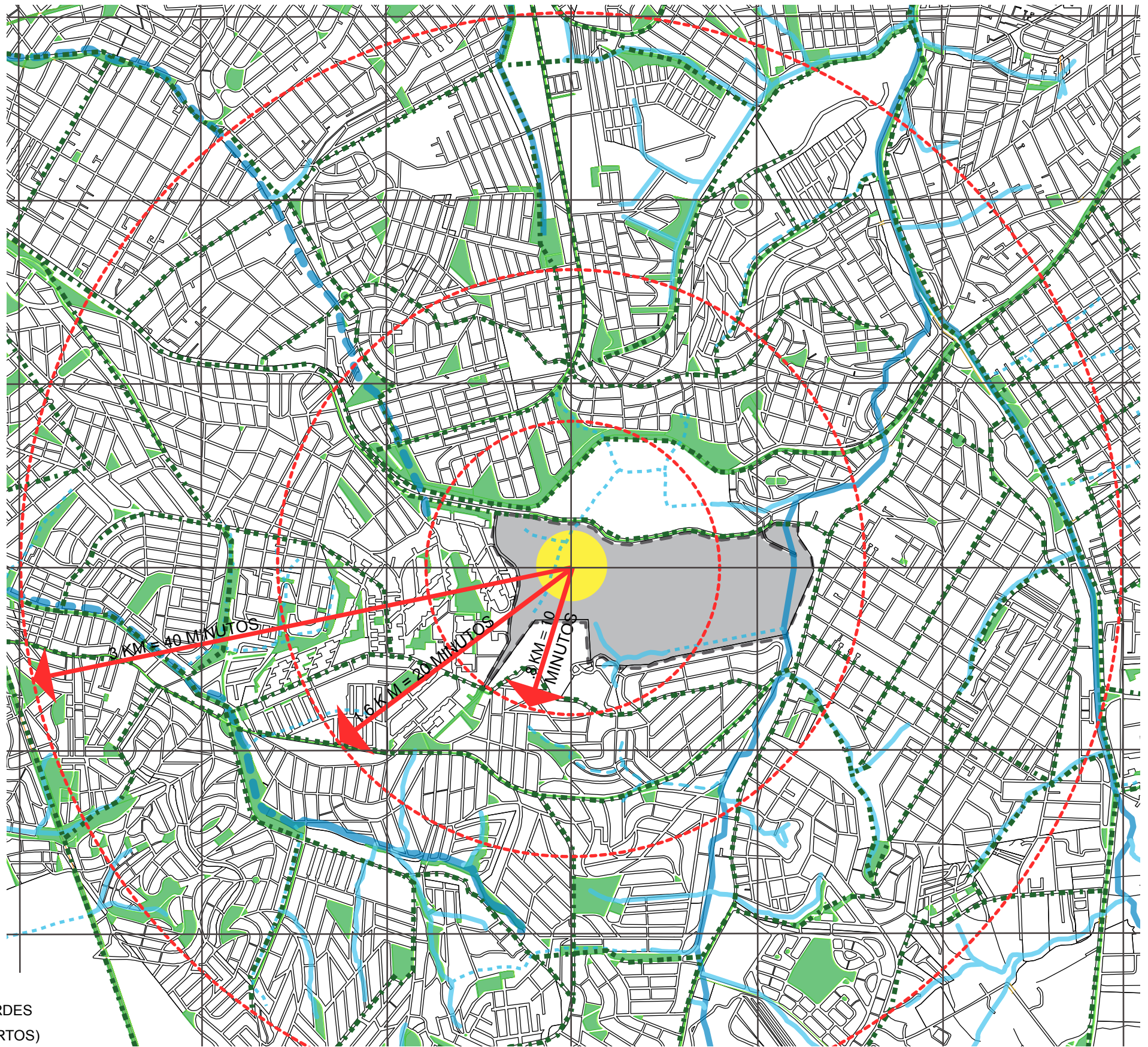

- PRAÇAS, CORREDORES, E ÁREAS VERDES

- RIOS PRINCIPAIS CANALIZADOS (ABERTOS)

- RIOS SECUNDÁRIOS (ABERTOS)

ESCALA 1:35000

- RIOS SECUNDÁRIOS CANALIZADOS (ABERTOS)

- : RIOS SECUNDÁRIOS CANALIZADOS (SUBTERRÂNEO)

- CÓRREGOS

- - CÓRREGOS CANALIZADOS (ABERTOS)

... CÓRREGOS CANALIZADOS (SUBTERRÂNEO)

(4) ARENA CORINTHIANS

JARDINS DE CHUVA

" : VIAS POTENCIAIS/JARDINS DE CHUVA

Figura 99: Jardins de chuva - sistema de drenagem natural com a substituição de infraestrutura tradicional. Fonte detalhe jardim de chuva: Prefeitura de Portland, 2004. Portland Stormwater Management Manual. Portland,OR, EUA: http://www.portlandoregon.gov/ bes/article/474218. Base: Mapa Digital da Cidade, SMDU, Prefeitura de São Paulo, 2004. Mapeamento: Patricia Akinaga. 


\section{JARDINS DE CHUVA}
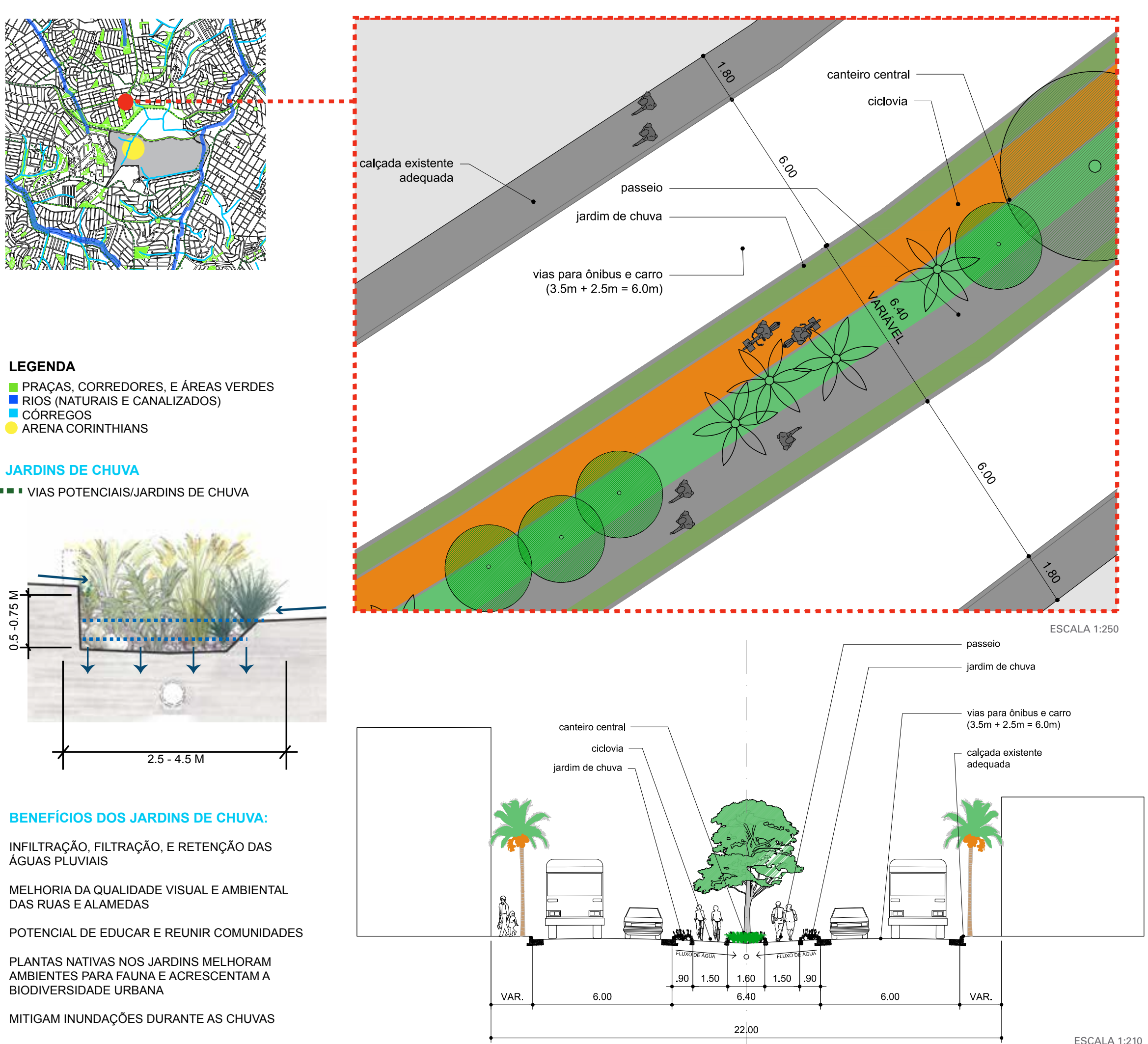

PRAÇAS, CORREDORES, E ÁREAS VERDES

RIOS (NATURAIS E CANALIZADOS)

- RIOS (NATURAR

CÓRREGOS

JARDINS DE CHUVA

- " VIAS POTENCIAIS/JARDINS DE CHUVA

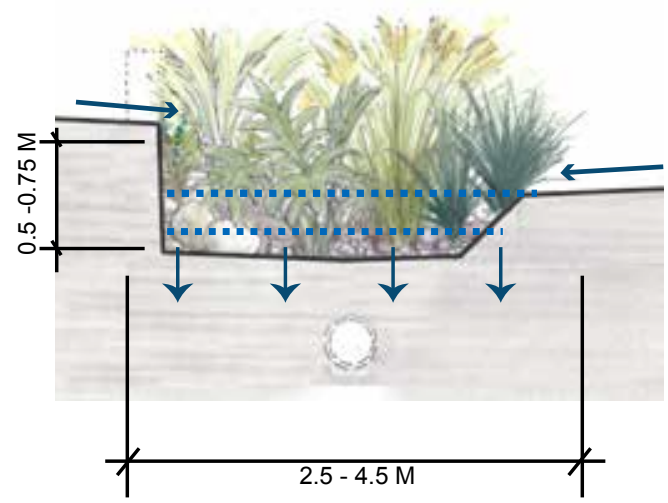

BENEFÍCIOS DOS JARDINS DE CHUVA:

INFILTRAÇÃO, FILTRAÇÃO, E RETENÇÃO DAS ÁGUAS PLUVIAIS

MELHORIA DA QUALIDADE VISUAL E AMBIENTAL DAS RUAS E ALAMEDAS

POTENCIAL DE EDUCAR E REUNIR COMUNIDADES

PLANTAS NATIVAS NOS JARDINS MELHORAM AMBIENTES PARA FAUNA E ACRESCENTAM A BIODIVERSIDADE URBANA

MITIGAM INUNDAÇ̃̃ES DURANTE AS CHUVAS

Figura 100: Sistema de drenagem natural com a substituição gradual da infraestrutura tradicional. Fonte detalhe jardim de chuva: Prefeitura de Portland, 2004. Portland Stormwater Management Manual. Portland,OR, EUA: http://www.portlandoregon.gov/bes/article/474218. Base: Mapa Digital da Cidade, SMDU, Prefeitura de São Paulo, 2004. Planta e corte: Patricia Akinaga. 


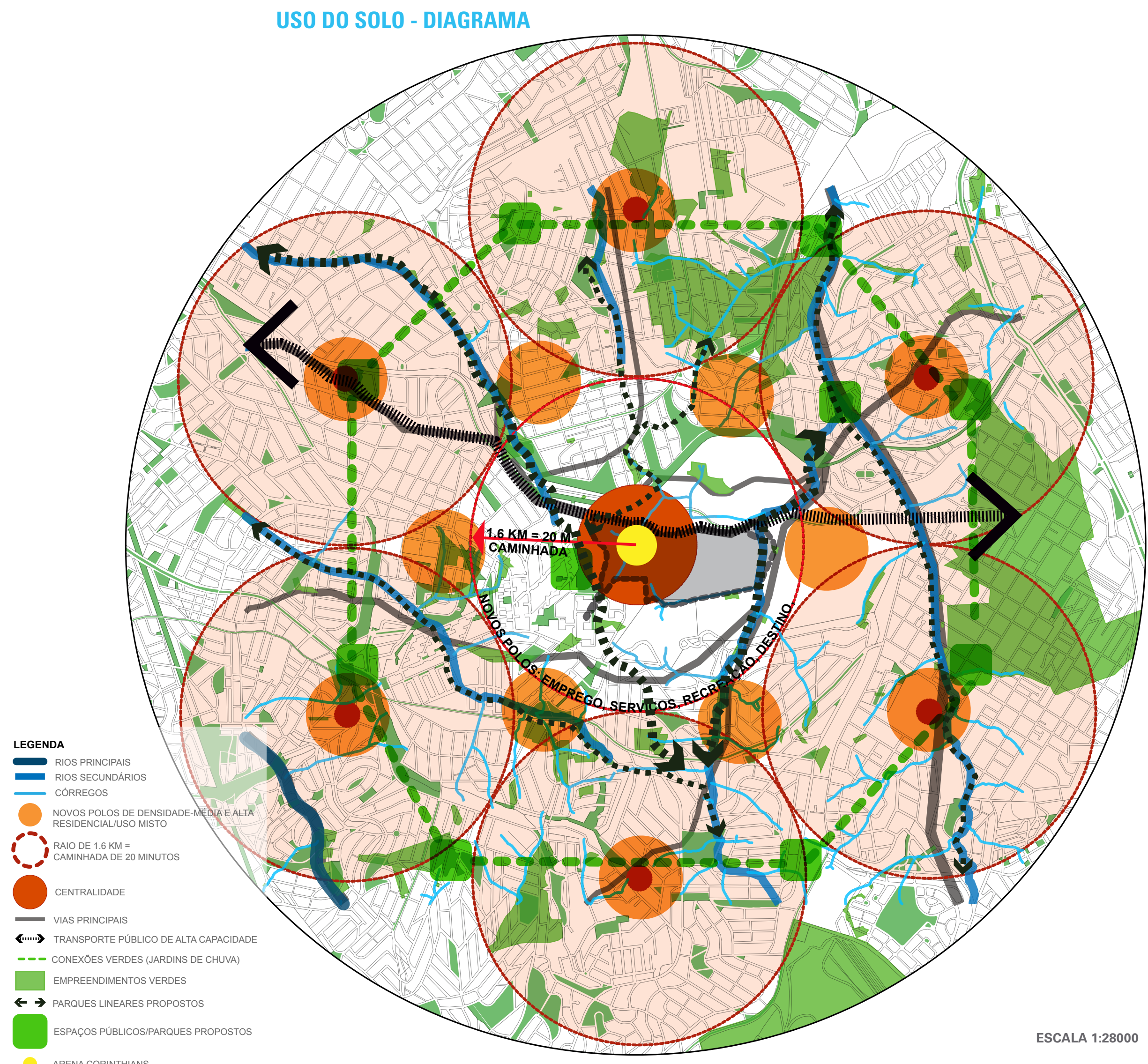

Figura 101: Criação de novas centralidades (uso do solo, diversificação, e densidades média e alta). Fonte: Transit Oriented Development Guidelines, Prefeitura de São Francisco, CA, EUA: http://www.bart.gov/sites/default/files/docs/TOD_Guidlines.pdf. Base: Mapa Digital da Cidade, SMDU, Prefeitura de São Paulo, 2004. Diagrama: Patricia Akinaga. 


\section{CONTEXTO URBANO - PAISAGEM EXISTENTE NO ENTORNO DA ARENA CORINTHIANS}
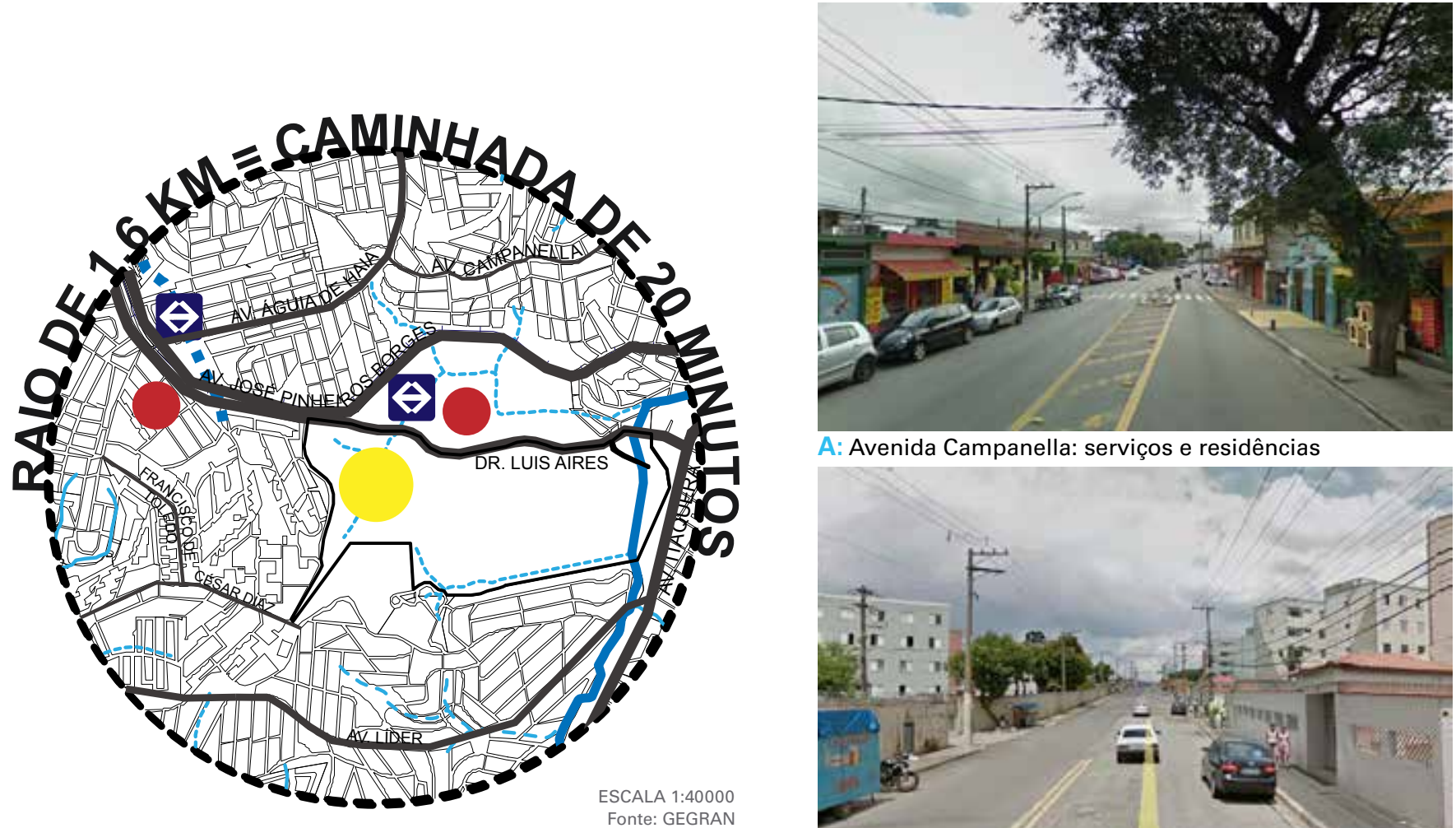

A: Avenida Campanella: serviços e residências
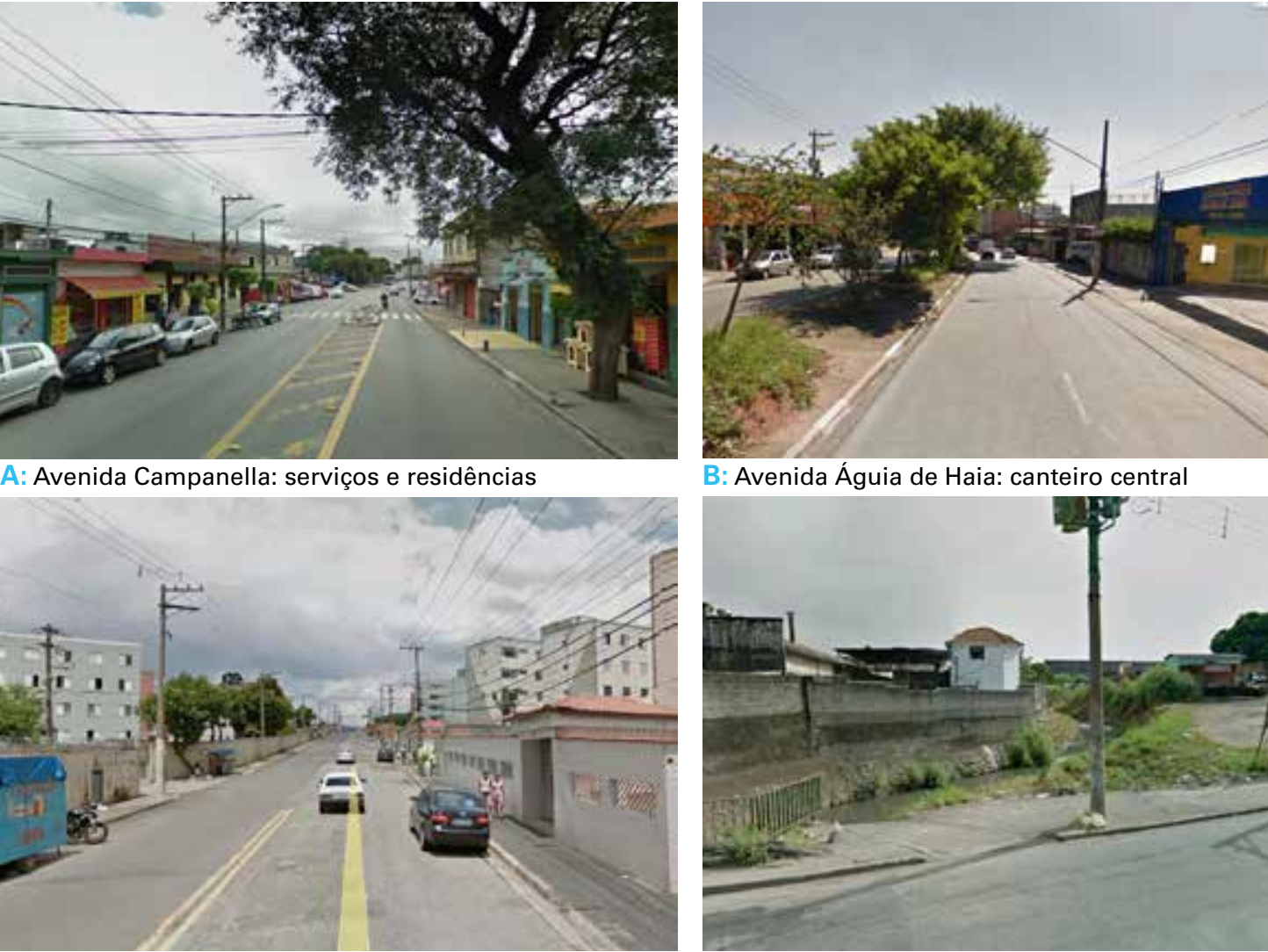

B: Avenida Águia de Haia: canteiro central

\section{LEGENDA}

RIOS SECUNDÁRIOS (ABERTOS)

- - RIOS SECUNDÁRIOS CANALIZADOS (SUBTERRÂNEO)

- - CÓRREGOS CANALIZADOS (ABERTOS) CÓRREGOS CANALIZADOS (SUBTERRÂNEO)

— CÓRREGOS

- ARENACORINTHIANS

- VIAS ARTERIAIS

VIAS COLETORAS

— VIAS LOCAIS

$\longrightarrow$ FERROVIAS

- terminal uRBano DE PASSAGEIROS

- ESTAÇÃO METROVIÁRIA
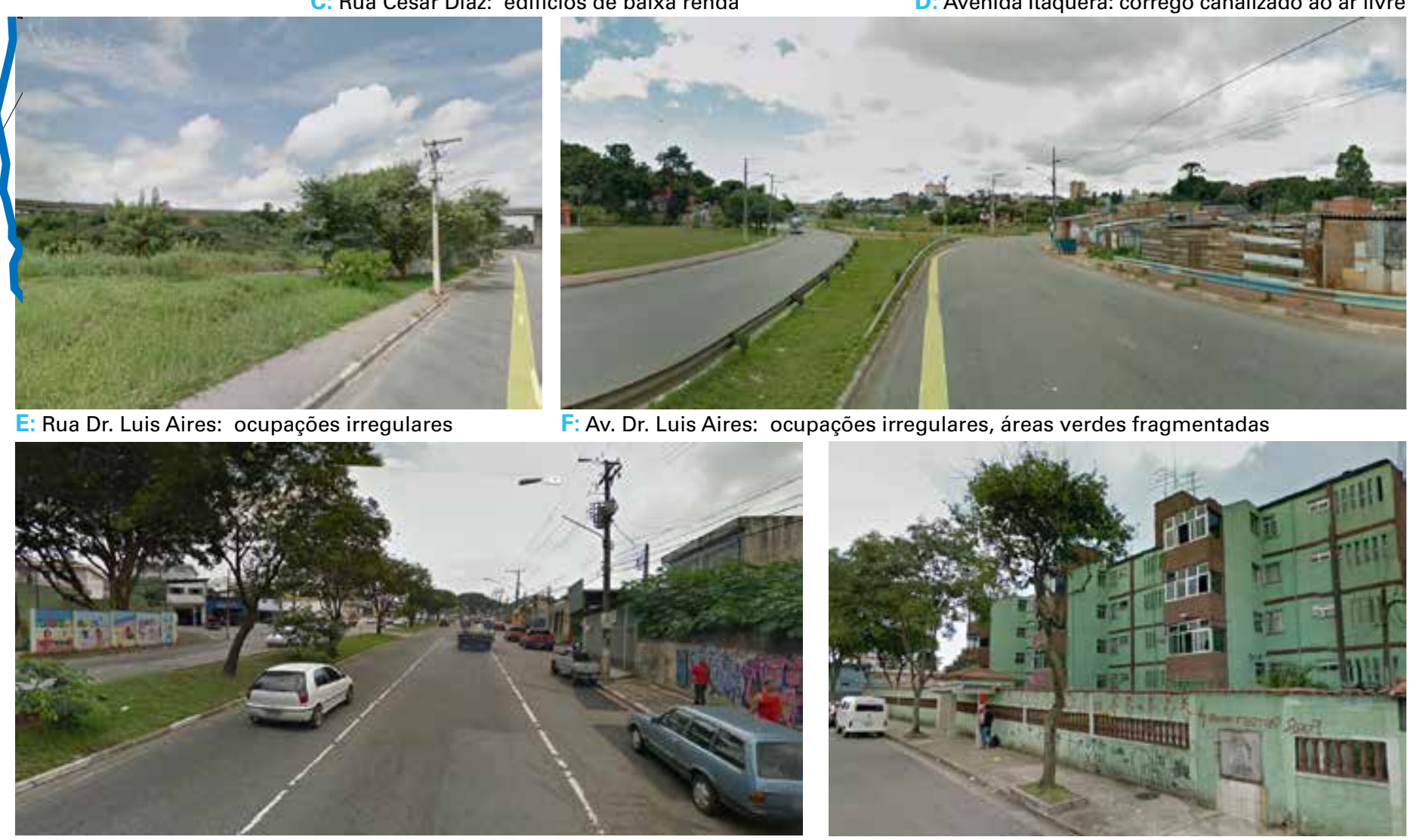

G: Avenida Líder: serviços e residências

H: Av. Padre Francisco de Toledo: edifícios de baixa renda

Figura 102: Paisagem existente no entorno da arena. Base: Mapa Digital da Cidade, SMDU, Prefeitura de São Paulo, 2004 Mapeamento: Patricia Akinaga. Imagem de satélite: Google Earth, 2011. 


\section{CONTEXTO URBANO - PAISAGEM PROPOSTA NO ENTORNO DA ARENA CORINTHIANS}
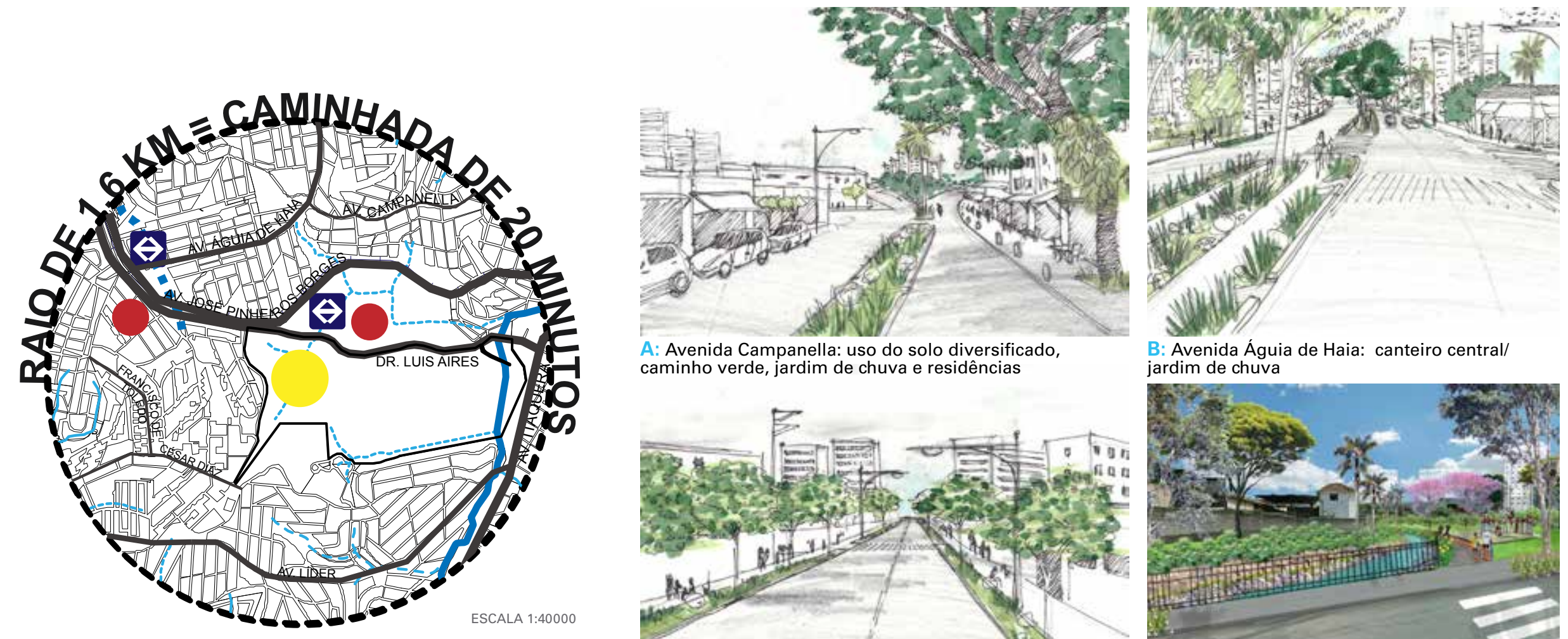
caminho verde, jardim de chuva e residências

B: Avenida Águia de Haia: canteiro central/

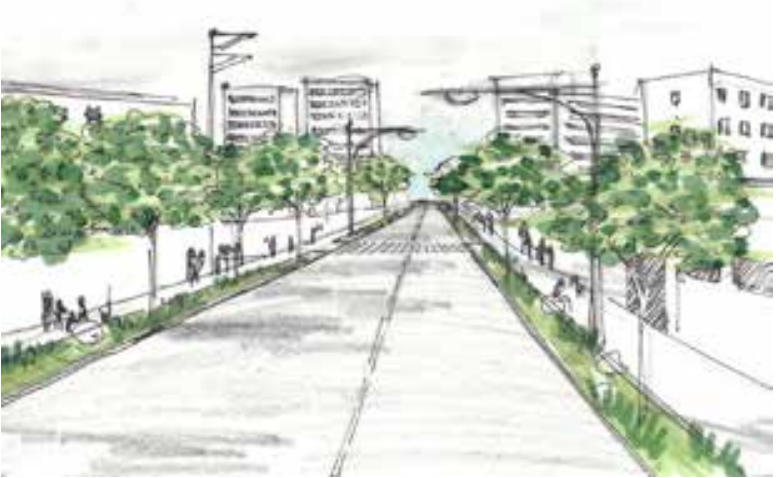

C: Rua Cesar Dlaz: empreendimentos verdes

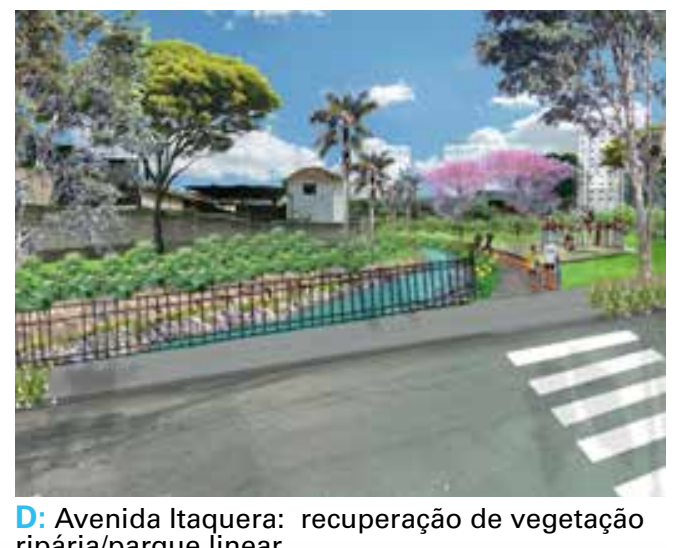

LEGENDA RIOS SECUNDÁRIOS
(ABERTOS)

- घ RIOS SECUNDÁRIOS CANALIZADOS (SUBTERRÂNEO)

- - CÓRREGOS CANALIZADOS (ABERTOS)

-.---- CÓRREGOS CANALIZADOS (SUBTERRÂNEO)

CÓRREGOS

ARENA CORINTHIANS

- VIAS ARTERIAIS

- VIAS COLETORAS

— VIAS LOCAIS

$\longrightarrow$ FERROVIAS

- TERMINAL URBANO DE PASSAGEIROS

• ESTAÇÃO METROVIÁRIA
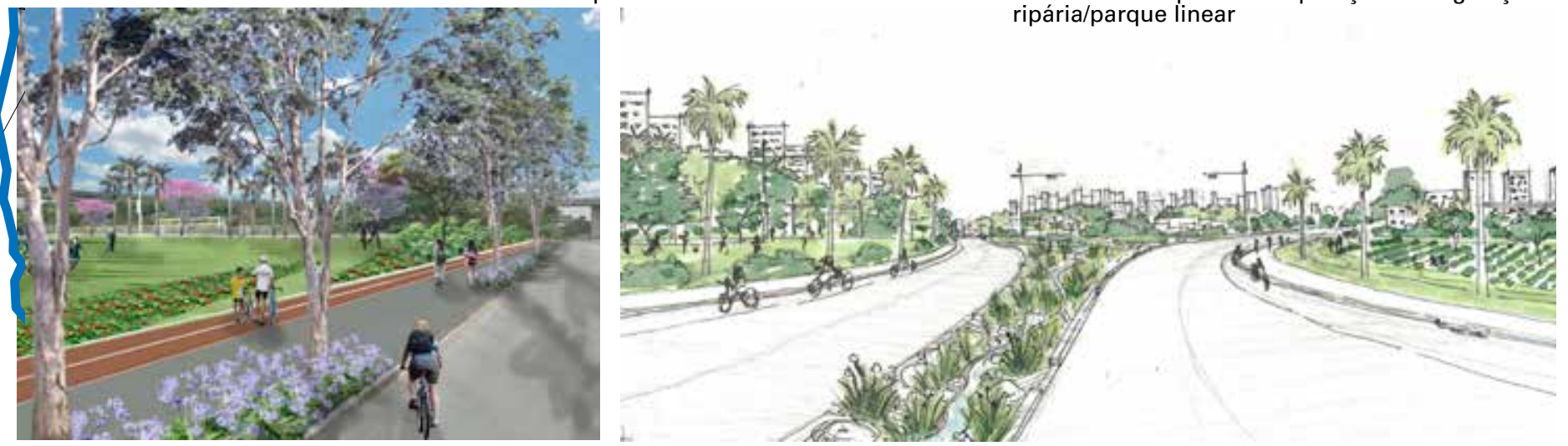

Rua Dr. Luis Aires: novas áreas verdes

F: Rua Dr. Luis Aires: empreendimentos verdes, áreas verdes conectadas

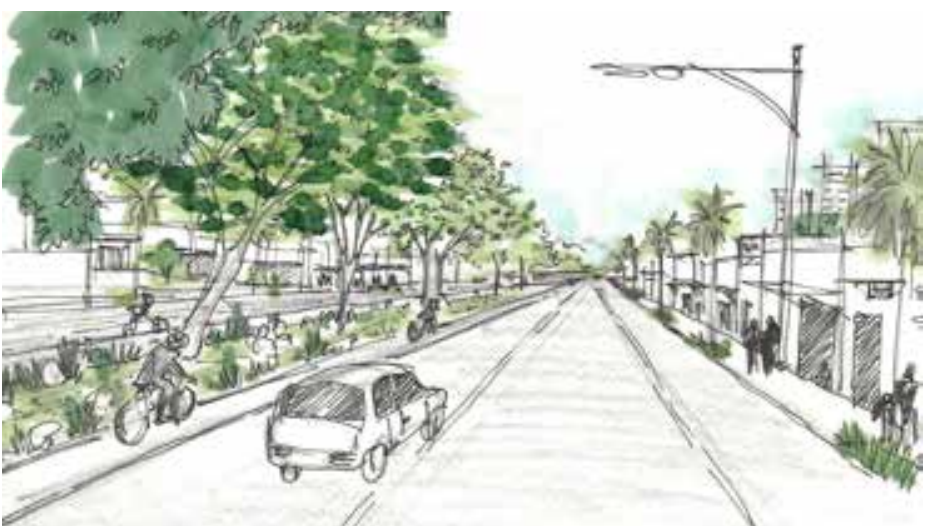

G: Av. Líder: jardins de chuva, uso do solo diversificado, ciclovia, trilhas

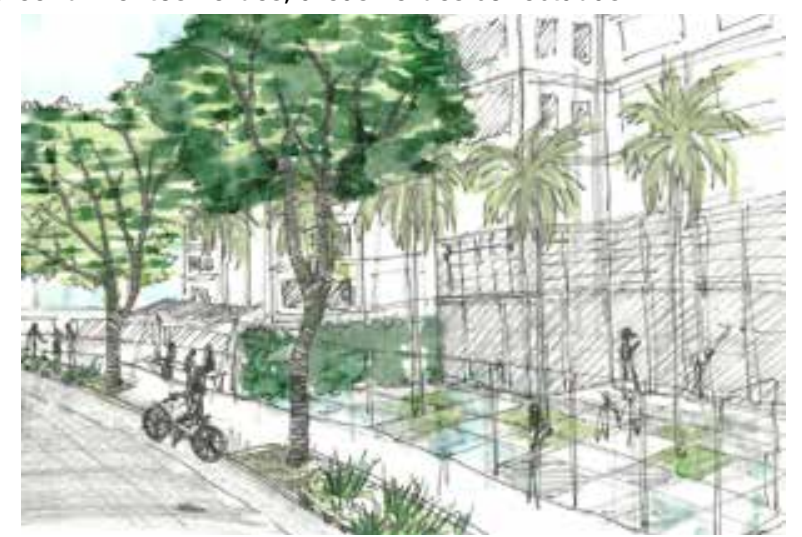

H: Padre Francisco deToledo: empreendimentos verdes

Figura 103: Paisagem proposta no entorno da arena. Base: Mapa Digital da Cidade, SMDU, Prefeitura de São Paulo, 2004 Mapeamento e ilustrações: Patricia Akinaga. Imagem de satélite: Google Earth, 2011. 
Princípios do Urbanismo Ecológico como a implantação gradativa de infraestrutura verde (figura 102 e 103), a estruturação urbana a partir dos cursos d'água, a criação de ruas completas voltadas ao pedestre, ao ciclista e ao transporte público, a diversificação do uso do solo e a constituição de novas centralidades (figura 101), se incorporados ao Plano Diretor do Município de São Paulo, poderão transformar a paisagem e a realidade de Itaquera e da Zona Leste (figuras 104, 105, 106 e 107). As transformações urbanas em curso, em função da Copa de 2014, sem dúvida, são excelentes pontos de partida e que geram reflexões e ações, sobretudo captam a atenção para uma zona da cidade por muito tempo segregada e alheia às inovações. 


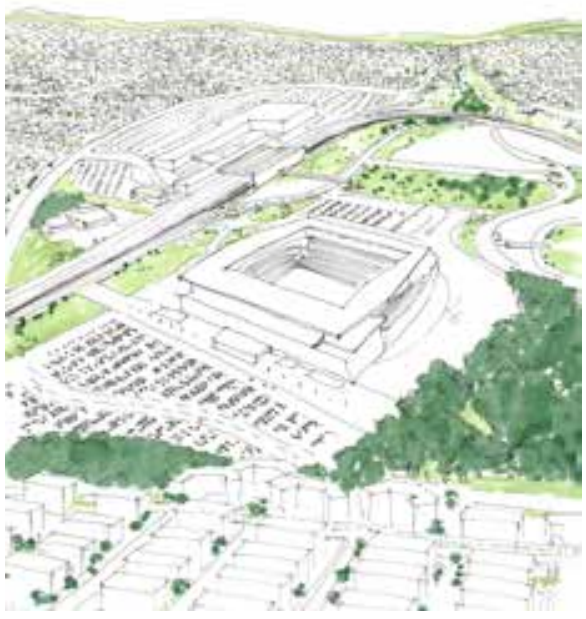

Figura 104: Paisagem existente no entorno da Arena Corinthians.

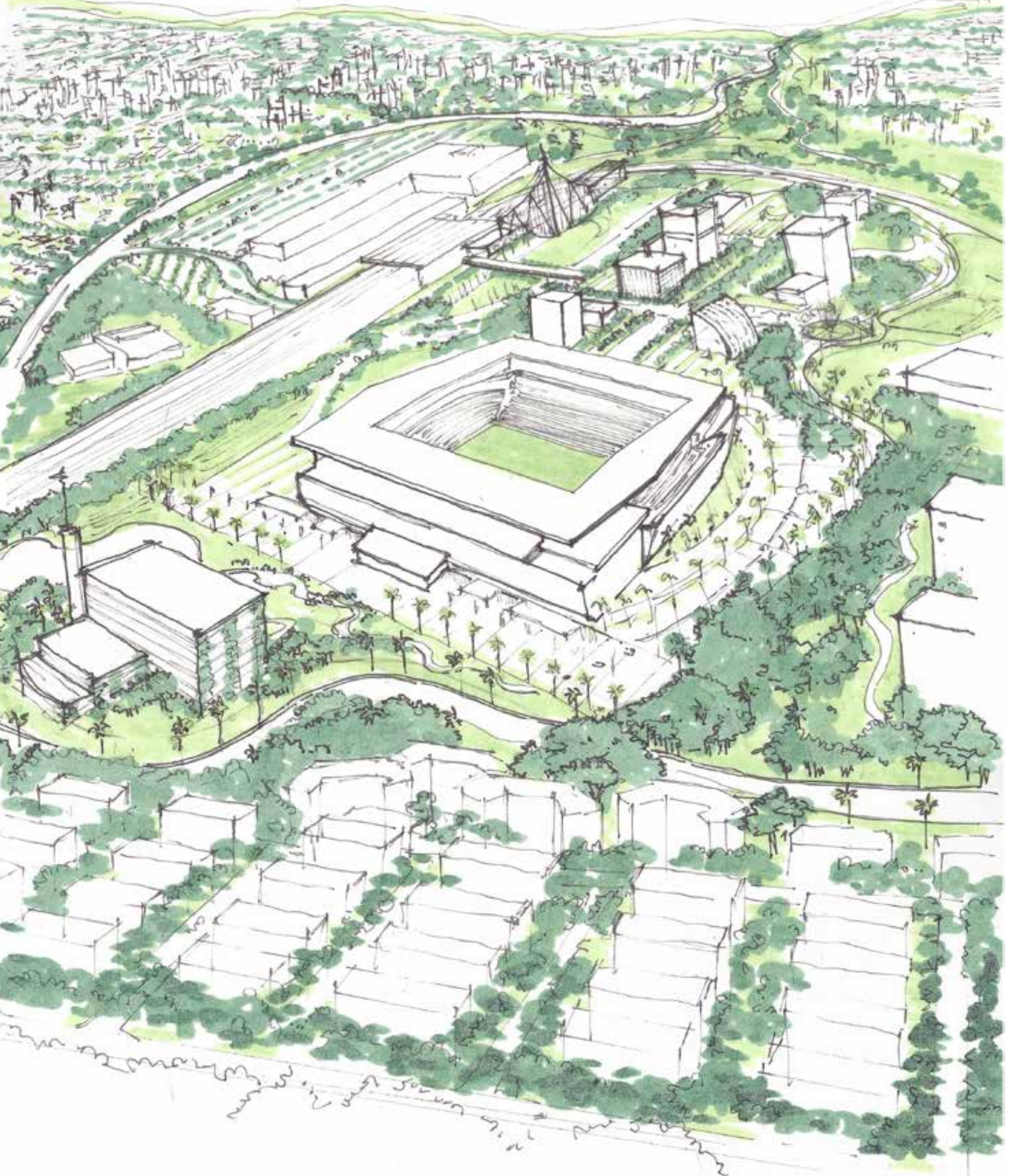

Figura 105: Paisagem urbana no entorno da Arena Corinthians após aplicação dos princípios do Urbanismo Ecológico. Ilustração: Genevieve A. Buentello, Patricia Akinaga 


\section{ARENA CORINTHIANS, SÃO PAULO, BRASIL - ANTES}

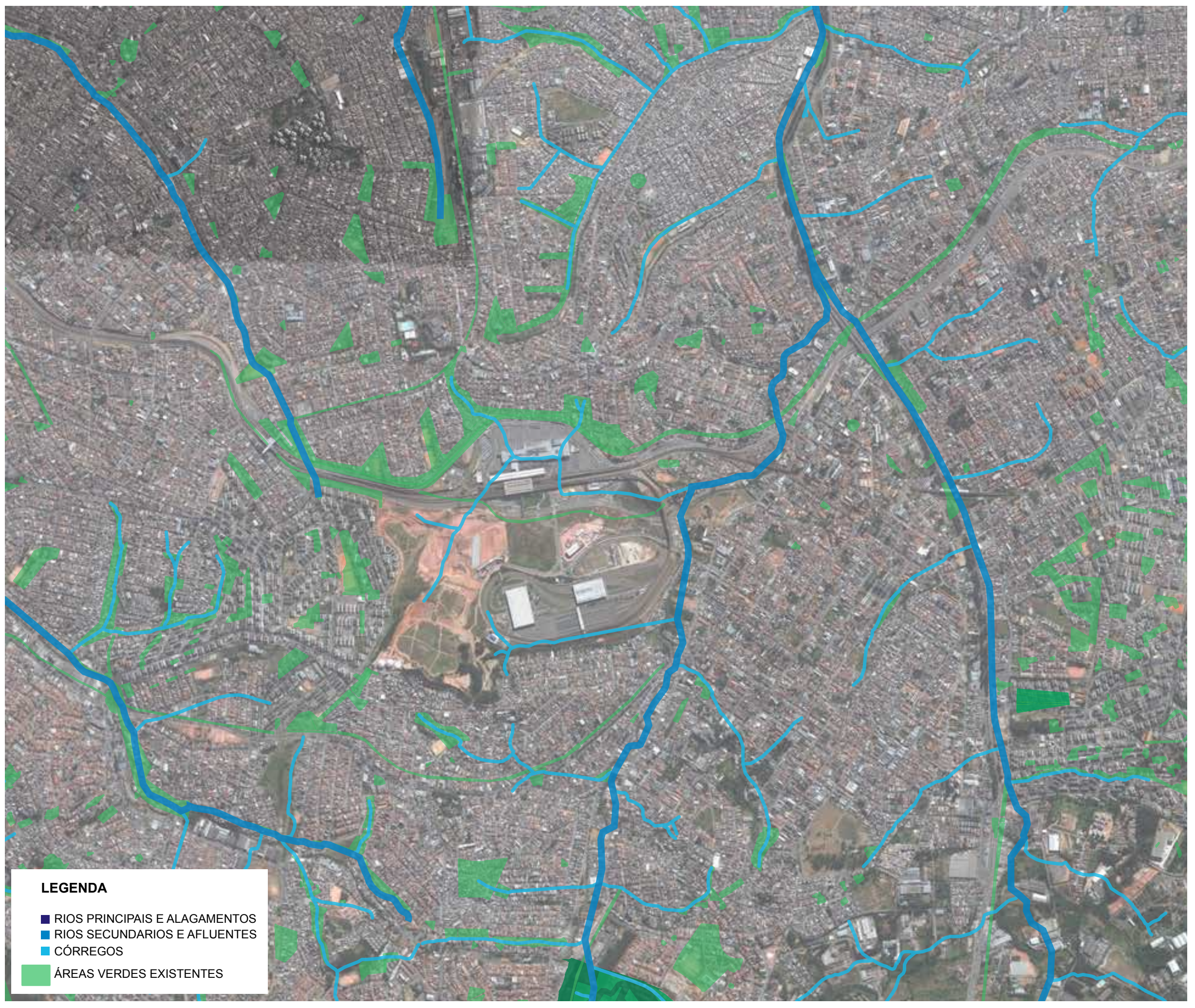

ESCALA 1:25000

Figura 106: Área antes da construção da Arena Corinthians e arredores: áreas verdes fragmentadas. Base: Mapa Digital da Cidade, SMDU, Prefeitura de São Paulo, 2004. Mapeamento: Patricia Akinaga. Imagem de satélite: Google Earth, 2011 


\section{ARENA CORINTHIANS, SÃO PAULO, BRASIL - DEPOIS}

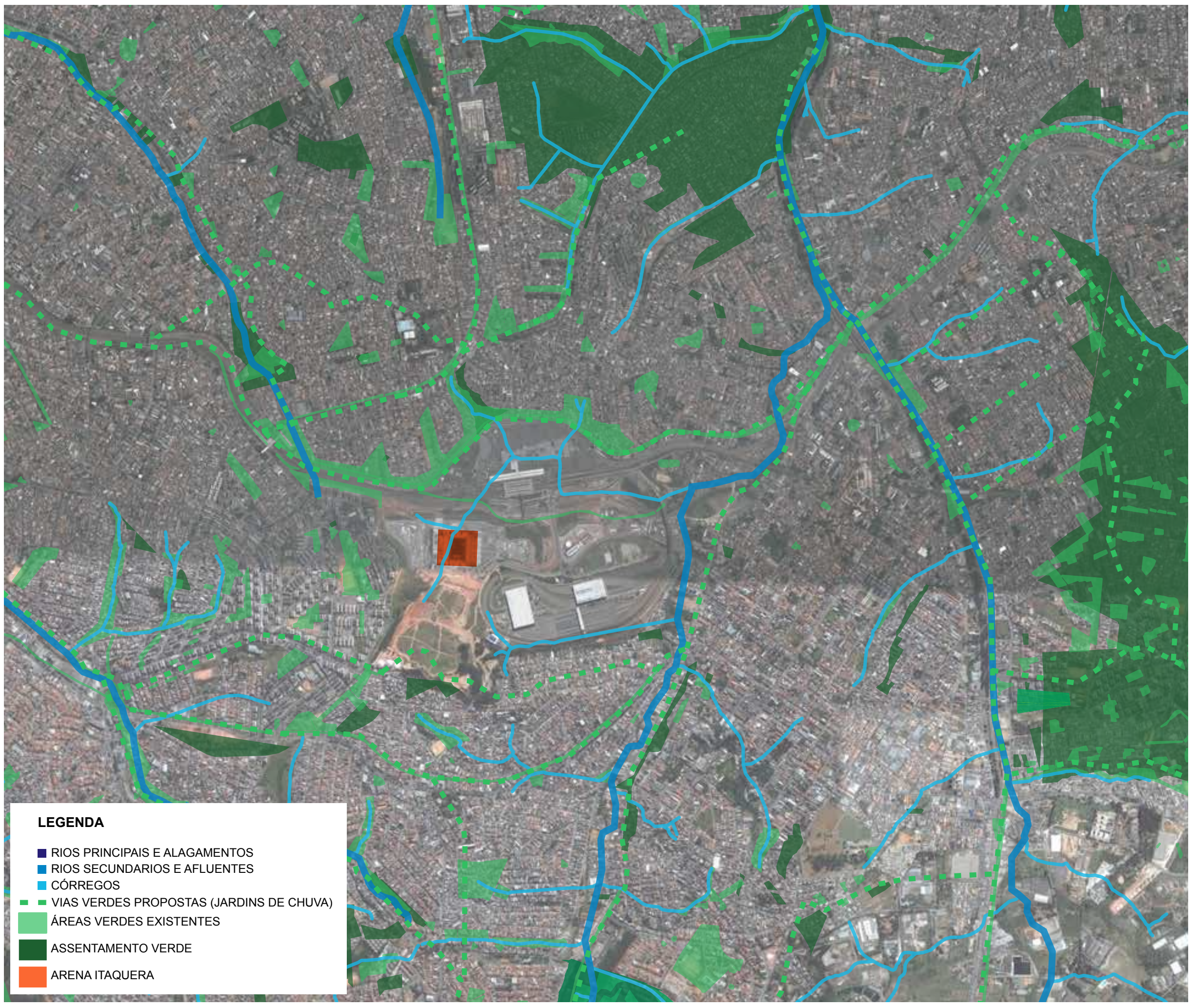

ESCALA 1:25000

Figura 107: Áreas verdes públicas no entorno da Arena Corinthians com a implementação do Urbanismo Ecológico: jardins de chuva, áreas verdes qualificadas e conectadas, uso do solo diversificado, novas centralidades. Base: Mapa Digital da Cidade SMDU, Prefeitura de São Paulo, 2004. Mapeamento: Patricia Akinaga. Imagem de satélite: Google Earth, 2014 


\section{CONCLUSÃO}

Como mitigar os impactos ambientais causados pela urbanização crescente? Os estudos de caso apresentados nesta pesquisa permite-nos concluir que o Urbanismo Ecológico está no caminho certo para se atingir o objetivo de se criar um maior equilíbrio entre a ocupação e a preservação dos recursos naturais nos centros urbanos, e que tem como consequência direta a melhoria da qualidade de vida, gerando benefícios para a saúde e segurança públicas. Não é tarde para se repensar a cidade do futuro e fatos recorrentes em São Paulo como enchentes, as ocupações irregulares nas áreas de fragilidade ambiental, a degradação e o esgotamento dos recursos naturais fazem com que esta ação seja necessária e urgente.

Conclui-se que o conceito de paisagem e natureza na cidade são distintos. A paisagem incorpora os sistemas humanos e naturais, aspectos sociais, econômicos e ecológicos na sua essência. Busca-se, através da qualificação dos percursos na cidade uma maior interação entre as pessoas, os rios, as áreas verdes e a arquitetura moldando uma nova paisagem cotidiana.

O Plano para São Paulo 2040, elaborado pela Prefeitura de São Paulo, prevê para a cidade uma rede eficiente de transporte público, a despoluição total dos cursos d'água e a construção de empreendimentos de uso misto para atender a todas as faixas de renda e promover geração de empregos e igualdade social. O pacto entre os diversos segmentos da sociedade é fundamental para a concretização desta visão. Projetos denominados verdes, ecológicos, se isolados, não promovem a transformação urbana necessária, no entanto, têm um papel importante na divulgação de ideias e princípios ecológicos e funcionam como agentes da sonhada sustentabilidade. Atuam de fato como instrumentos de propaganda.

Para que o Urbanismo Ecológico se torne realidade, é importante que sejam incluídas na legislação urbana municipal, no Plano Diretor, diretrizes claras de um Urbanismo que incorpore a paisagem de forma estrutural e não acessória. Pressupõe-se a integração de espaços verdes públicos como artefato da infraestrutura verde urbana que exerce a função de amortecimento, retenção e tratamento das águas pluviais, conexão entre áreas verdes importantes, além de resultar em um ambiente urbano mais saudável para a população. 
A partir das leituras realizadas no bairro de Itaquera conclui-se que a implantação do Urbanismo Ecológico em São Paulo é possível e resultado do pacto entre o poder público, a iniciativa privada e a comunidade. É necessário reconfigurar o traçado viário e retomar os cursos d'água como elementos estruturadores do desenho urbano, juntamente com as áreas verdes, além de promover a implantação de bairros ecológicos, a diversificação do uso do solo, a melhoria do transporte público, a criação de percursos adequados para ciclistas e pedestres e o uso de lotes vazios e subutilizados como novas âncoras da infraestrutura verde.

Como vimos no capítulo 8, a Arena Corinthians exerce a função de elemento catalisador para a transformação social e física em Itaquera. Investimentos dos operadores da Arena Corinthians no seu entorno imediato em equipamentos e espaços públicos, sistema de drenagem natural e jardins comunitários podem ser contrapartidas importantes exigidas pelo poder público, além da geração de novos empregos e democratização da arena multiuso, através da organização de programas esportivos destinados à comunidade.

As ações na Zona Leste deverão ser sustentadas pelo Plano Diretor, a ser revisado e pautado pelo debate ambiental e pelo paradigma ecológico no desenvolvimento da cidade contemporânea, com um novo modelo de assentamento, que concilia a ocupação urbana e as ações antrópicas com a capacidade de suporte dos elementos naturais como a topografia, os cursos d'água, a fauna e a flora.

As evidências encontradas na pesquisa, como nos projetos Piggybackyard e STAPLES Center, na cidade de Los Angeles, Califórnia, apontam para o papel do arquiteto paisagista e urbanista como chave na configuração do Urbanismo Ecológico, com a criação de valor e senso de lugar nos espaços projetados e na articulação entre os anseios dos diversos setores da sociedade através do processo participativo.

O impacto das arenas de futebol na paisagem vai além de sua arquitetura e gera reflexões. Toda a infraestrutura do entorno sofre alterações significativas. Podemos aproveitar esta oportunidade e fazer dela o legado fundamental que a Copa 2014 deixará para o país, o ponto de partida para a melhoria da qualidade de vida urbana e a transformação social necessária para apoiá-la (figura 108). 


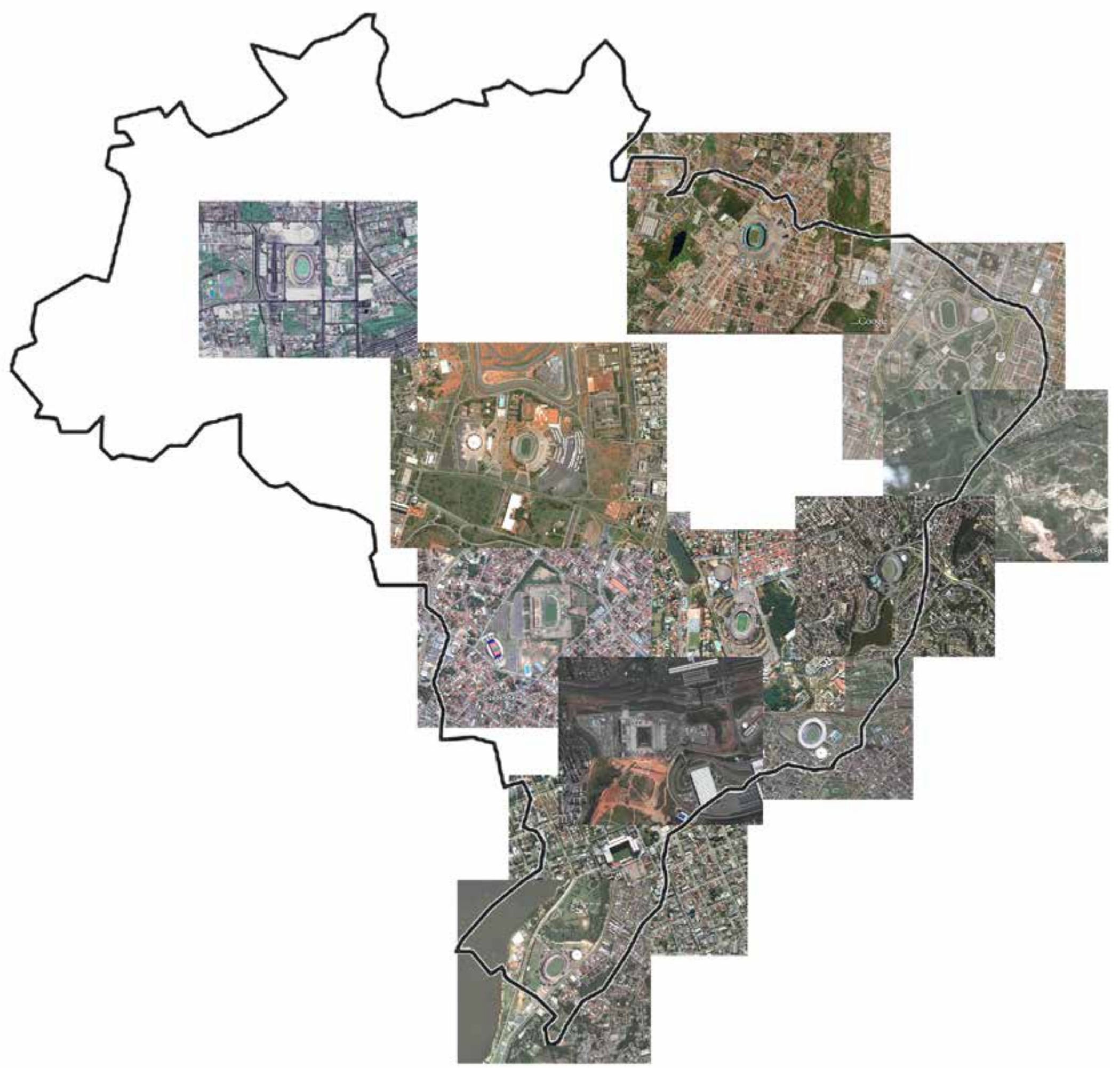

Figura 108: Arenas de futebol nas cidades sede da Copa do Mundo 2014 no Brasil. Fonte: Patrícia Akinaga 


\section{REFERÊNCIAS CITADAS}

ALEXANDER, C.; ISHIKAWA, S.; SILVERSTEIN, M. A pattern language: towns, buildings, construction. Oxford University Press: London, 1977.

ARGAN, G. C. The City as a Work of Art. Barcelona, Spaces and Sculptures (1982-1986), Barcelona 1987.

BENEDICT, M. A., McMAHON, E. T. Green Infrastructure, Linking Landscapes and communities. Washington: Island Press, 2006.

DUANY, A., SPECK J.; LYDON, M. The Smart Growth Manual. Nova York: McGraw Hill, 2010.

FARR, D. Sustainable urbanism: urban design with nature. New Jersey: John Wiley \& Sons, 2008.

FORMAN, R. T. T., Land Mosaics: The Ecology of Landscapes and Regions. Cambridge, UK: Cambridge University Press, 1995.

FRANCIS, M;CASHDAN L.;PAXSON, L. Community Open Spaces: Greening Neighborhoods Through Community Action and Land Conservation. Washington, D.C.: Island Press, 1984.

FRANCO, M. A. R. Planejamento Ambiental para a cidade sustentável. São Paulo: Annablume: FAPESP, 2001.

FRIENDS OFTHE LOS ANGELES RIVER; RIVER REVITALIZATION CORPORATION. The Piggyback yard feasibility study introduction. Report. Los Angeles, 2013.

GAINES, J.; JAGER, S. Albert Speer \& Partner, A Manifesto for Sustainable Cities, Think local, Act Global. Munich: Prestel, 2009.

HOU, J.; JOHNSON J. M.; LAWSON, L. J. Greening Cities, Growing communities, Learning from Seattle's Urban Community Gardens. Seattle: University of Washington Press, 2009. 
HOUGH, M. Ciudad y Naturaleza. Planificación Urbana y Processos Ecológicos. Barcelona: Gustavo Pili, 1998 (1995).

LAWSON, L. J. City Bountiful, a Century of Community Gardening in America. Berkeley: University of California Press, 2005.

MC'HARG, I. L. Proyetar con la Naturaleza. Barcelona: Gustavo Pili, 2000 (1967).

MERRIAM - WEBSTER. Merriam-Webster's Collegiate Dictionary. 11. ed. Springfield, MA: Merriam-Webster, 2003.

MEYER, R. M. P.; GROSTEIN, M. D. A leste do centro: territórios do urbanismo. São Paulo: Imprensa Oficial do Estado de São Paulo, 2010.

MIA LEHRER + ASSOCIATES; PCR; Sedway Group. Parks and Recreation Assessment Study. Report. Los Angeles, 2002.

MOSTAFAVI, M.; DOHERTY, G. Ecological Urbanism. Suiça: Lars Muller Publishers, 2010/2013. PALMBOOM, F.;VAN DEN BOUT, J.;RUITENBEEK, J.;BETSKY, A. Drawing the ground - Landscape Urbanism today. The work of Palmbout Urban Landscapes. Suiça: Birkhauser GmbK Basel, 2010.

SÃO PAULO (Prefeitura). Secretaria Municipal de Desenvolvimento Urbano (SMDU). Departamento de Urbanismo- DEURB. Polo Institucional Itaquera: Diretrizes de projeto urbanístico. São Paulo, SP, 2012.

SEATTLE (Prefeitura). Seattle Public Utilities. Natural Drainage Systems Booklet. Seattle, 2007. SPIRN, A. O Jardim de Granito. São Paulo, Edusp,1995

WALDHEIM, C. The Landscape Urbanism Reader. NovaYork: Princeton Architectural Press, 2006. 


\section{REFERÊNCIAS CONSULTADAS}

AB'SÁBER, A. et al. Projeto Floram e desenvolvimento sustentável. Estudos Avançados. São Paulo: IEA/ USP, n.27, maio/ago. 1996.

ADRIAENS, F.; DUBBELING, M.; FEDDES, F; MARCELIS, A.; VAN OVERVELD C.,STRUBEN, H.; VAN DER VEEN, D.; de VRIES J.; WITBERG, M.; ZINGER, E. Sustainable urban design, perspectives and examples. Amsterdam: Blauwdruk Publishers Wageningen, 2005.

AFONSO, C. Sustentabilidade: caminho ou utopia? São Paulo: Annablume, 2006.

BONDUKI, N. Origens da habitação social no Brasil. São Paulo: Estação Liberdade; FAPESP, 1998.

CALTHORPE, P. Urbanism in the age of climate change. Washington: Island, 2011.

CAMPOS, C. M. Os rumos da cidade: urbanismo e modernização em São Paulo. São Paulo: SENAC, 2002.

CHACEL, F. Paisagismo e Ecogênese. Rio de Janeiro: Fraiha, 2001.

CONDOM, P. M. Seven rules for sustainable communities. Design strategies for the Post Carbon World. Washington: Island Press, 2010.

DUANY, A.; PLATER-ZYBERK, E.; SPECK, J. Suburban nation: the rise of sprawl and the decline of the American dream. New York: North Point, 2010.

FLANNERY,T. The weather makers, how man is changing the climate and what it means for life on Earth. New York: Grove Press, 2005.

FRANCO, M. A. R. Desenho ambiental. S. Paulo: Annablume: FAPESP, 2008 (1997).

GEHL, J.; ROGERS, R. Cities for people. Washington: Island, 2010. 
GORGOLEWSKI, M.; KOMISAR, J.; NASR, J. Carrot City Creating places for urban agriculture. Nova York: The Monacelli Press, 2011.

HARVEY, D. A justiça social e a cidade de São Paulo. São Paulo: Hucitec, 1980.

JELLICOE, G.; JELLICOE, S. The landscape of man. Nova lorque:Thames \& Hudson, 1975.

JENKS, M., DEMPSEY, N. (Ed.). Future Forms and design for sustainable cities. Amsterdam: Architectural, 2005.

KINKADE-LEVARIO, H. Design for water, Rainwater Harvesting, Stormwater Catchment, and Alternate Water Reuse. Gabriola Island: New Society Publishers, 2007.

KLIASS, R. Parques urbanos de São Paulo e sua evolução na história. São Paulo: Pini, 1993.

KOOLHAAS, R. Mutations. Barcelona: Actar, 2001.

KOSTOF, S. The City Assembled, the Elements of Urban Form Through History. London: Bulfinch Press, 1992.

LAGRO, J. A. Site analysis: linking program and concept in land planning and design. New York: John Wiley \& Son, Inc., 2001.

LAURIE, M. Una introducción a la arquitectura del paisaje. Barcelona: G. Gili, 1992.

LEITE, C.; AWAD J. C. M. Cidades sustentáveis, cidades inteligentes: desenvolvimento sustentável num planeta urbano. Porto Alegre: Bookman, 2012.

LYLE, J. Design for human ecosystems: landscape, land use and natural resources. Washington DC: Island Press, 1999.

LYNCH, K. A boa forma da cidade. Lisboa: Edições 70, 1999.

MEYER, R. M. P.; GROSTEIN, M. D.. São Paulo metrópole. São Paulo: Edusp, 2004. 
MUMFORD, L. A cidade na história, suas origens, transformações e perspectivas. São Paulo: Martins Fontes/Ed. Universidade de Brasília, 1982.

ODUM, E. P. Ecologia. Rio de Janeiro: Guanabara, 1988.

OLMSTED, F. L. Central Park, as work of art and a great municipal enterprise. New York: G. P. Putnam's Sons, 1928.

OWEN, D. Green metropolis: why living smaller, living closer, and driving less are keys to sustainability. New York: Riverhead Books, 2009.

PEIXOTO, N. B. Paisagens urbanas. São Paulo: SENAC, 2003.

POWELL, K. City transformed. London:TeNeues, 2000.

REGISTER, R. Ecocities: Rebuilding Cities in Balance with Nature. Gabriola Island: New Society Publishers, 2006.

SÃO PAULO (Estado). Secretaria do Meio Ambiente do Estado de São Paulo. Atlas de conservação Ambiental do Estado de São Paulo. São Paulo: Metalivros, 1998.

SEATTLE (Prefeitura). Seattle City Council; Seattle Public Utilities. URS Corporation; Herrera Environmental Consultants, Inc.; Norton-Arnold Company. Seattle Solid Waste Recycling, Waste Reduction, and Facilities Opportunities. Seattle, 2007.

SOLÀ-MORALES, M. I R. Las Formas de Crescimiento Urbano. Barcelona: Editora UPC, 1997.

TOLEDO, B. L. São Paulo:Três cidades em um século. São Paulo: Duas Cidades, 1983.

WHEELER, S. M., BEATLEY,T. Sustainable urban development reader. London: Routledge, 2008. 


\section{ENDEREÇOS ELETRÔNICOS:}

http://www. ambiente.sp.gov.br. Acesso em 22 de Setembro de 2013.

http://www.ci.seattle.wa.us/util/naturalsystems/.Acesso em 20 de Setembro de 2011.

http://www.fauusp.br/depprojetos/labverde. Acesso em 10 de Fevereiro de 2013.

http://www. ibge.gov.br. Acesso em 22 de Agosto de 2013.

http://www.joburg.org.za/index.php?option=com_content\&view. Acesso em 18 de Novembro de 2013.

http://www.piggybackyard.org. Acesso em 14 de Junho de 2013.

http://www.portal2014.org.br/noticias/12492. Acesso em 09 de Novembro de 2013.

http://www.prefeitura.sp.gov.br/cidade/secretarias/desenvolvimento_urbano.Acesso em 04 de Agosto de 2013

http://www.rheoset.com.br/itaquerao. Acesso em 09 de Novembro de 2013.

http://www.sanfrancisco.giants.mlb.com. Acesso em 10 de Outubro de 2013

http://www.seattle.gov/util. Acesso em 21 de Julho de 2013

http://www.secovi.com.br. Acesso em Acesso em 14 de Junho de 2013

http://wetlands.sanbi.org/gumboot_article.php?id=169. Acesso em 20 de Agosto de 2013. 


\section{BASES PARA ELABORAÇÃO DOS MAPEAMENTOS:}

\section{Predominância do Uso 2012}

http://infocidade.prefeitura.sp.gov.br/mapas/17_uso_do_solo_urbano

2012_2012_10669.pdf.

Acesso em 20 de Agosto de 2013.

\section{Uso do Solo Predominante 2006}

http://www.usp.br/fau/cursos/graduacao/arq_urbanismo/disciplinas/aup0276/Municipio_de_ Sao_Paulo_-_2012/Mapas_Tematicos/Uso_do_Solo_Predominante_2005.pdf. Acesso em 20 de Agosto de 2013.

\section{Mapa das Regiões Metropolitanas/Localização Regional}

http://infocidade.prefeitura.sp.gov.br/mapas/3_localizacao_do_municipio_de_sao_paulo_2013 _10294.pdf. Acesso em 20 de Agosto de 2013.

\section{Mapa dos Distritos e Subprefeituras de São Paulo}

http://infocidade.prefeitura.sp.gov.br/mapas/3_regioes_subprefeituras_e_distritos_2013 _10338.pdf. Acesso em 23 de /setembro de 2013.

\section{Bacias Hidrográficas}

http://infocidade.prefeitura.sp.gov.br/mapas/2_bacias_hidrograficas_2012_10651.pdf. Acesso em 23 de Setembro de 2013.

\section{Áreas verdes}

http://infocidade.prefeitura.sp.gov.br/mapas/2_parques_e_unidades_de_conservacao_2012 _10652.pdf. Acesso em 18 de Junho de 2013.

\section{Uso do solo 2005}

http://sempla.prefeitura.sp.gov.br/mm/panorama/pdf/pag06.pdf. Acesso em 18 de Junho de 2013. 


\section{Equipamentos sociais, 2006}

http://sempla.prefeitura.sp.gov.br/mm/panorama/pdf/pag05.pdf. Acesso em 18 de Junho de 2013.

\section{Urban agriculture Guidelines}

Urban Agriculture Guidelines for the Private Realm. Prefeitura de Vancouver, British Colombia, Canadá, 2008: http://vancouver.ca/files/cov/urban-agriculture-guidelines.pdf. Acesso em 18 de Junho de 2013.

\section{Rainwater Gardens}

Fonte detalhe jardim de chuva: Prefeitura de Portland, 2004. Portland Stormwater Management Manual. Portland,OR, EUA: http://www.portlandoregon.gov/bes/article/474218. Acesso em 18 de Junho de 2013.

Transit Oriented Development Guidelines, Prefeitura de São Francisco, CA, EUA: http://www.bart.gov/sites/default/files/docs/TOD_Guidlines.pdf. Acesso em 15 de Março de 2013.

Todas as imagens sem referência são de autoria própria. 


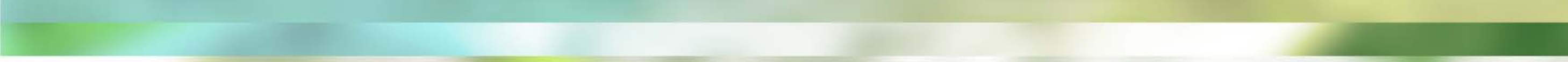

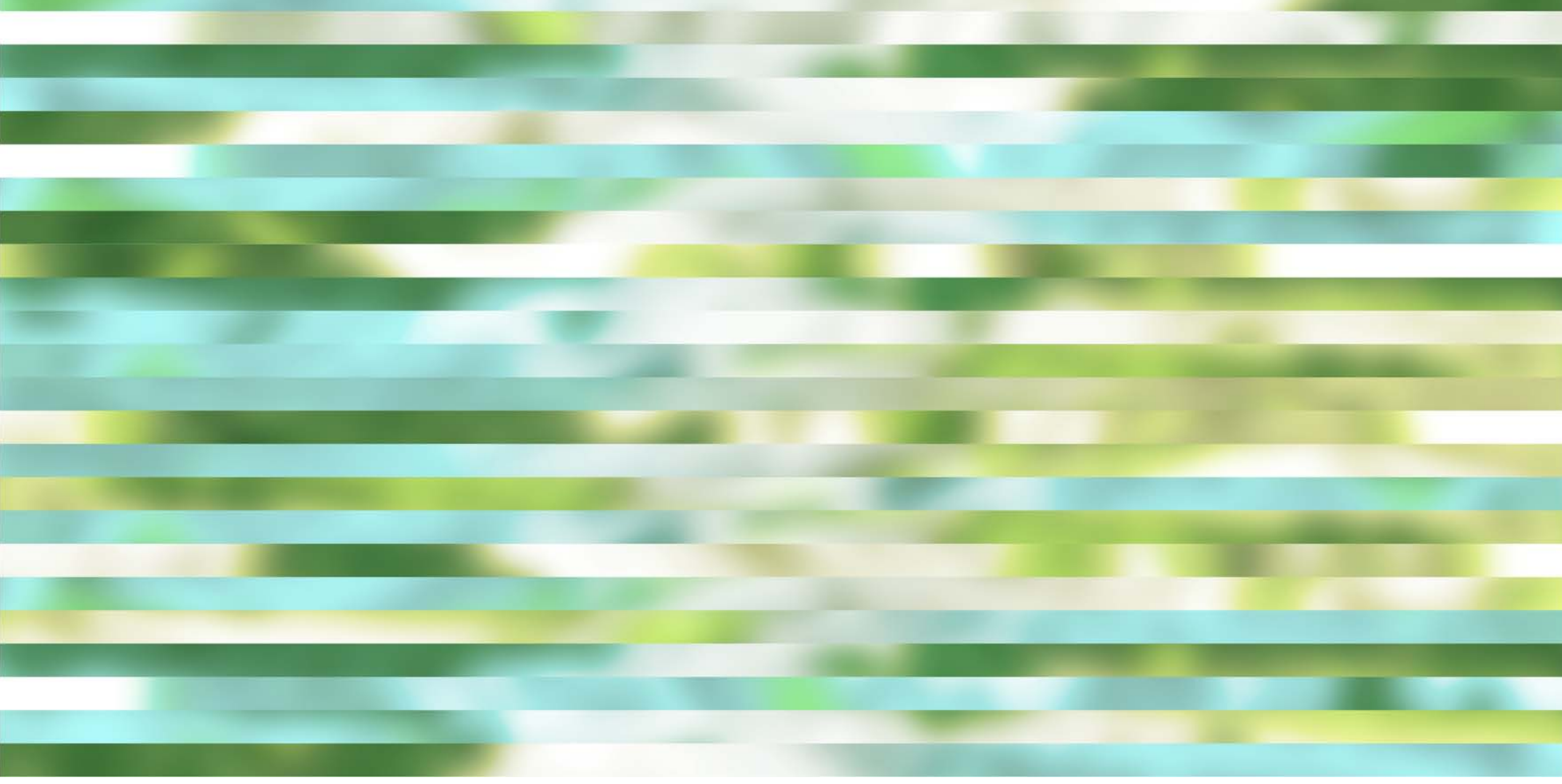

